Prepared in cooperation with the Kansas and Missouri Departments of Transportation

\title{
Bathymetric and Velocimetric Surveys at Highway Bridges Crossing the Missouri River in and into Missouri during Summer Flooding, July-August 2011
}

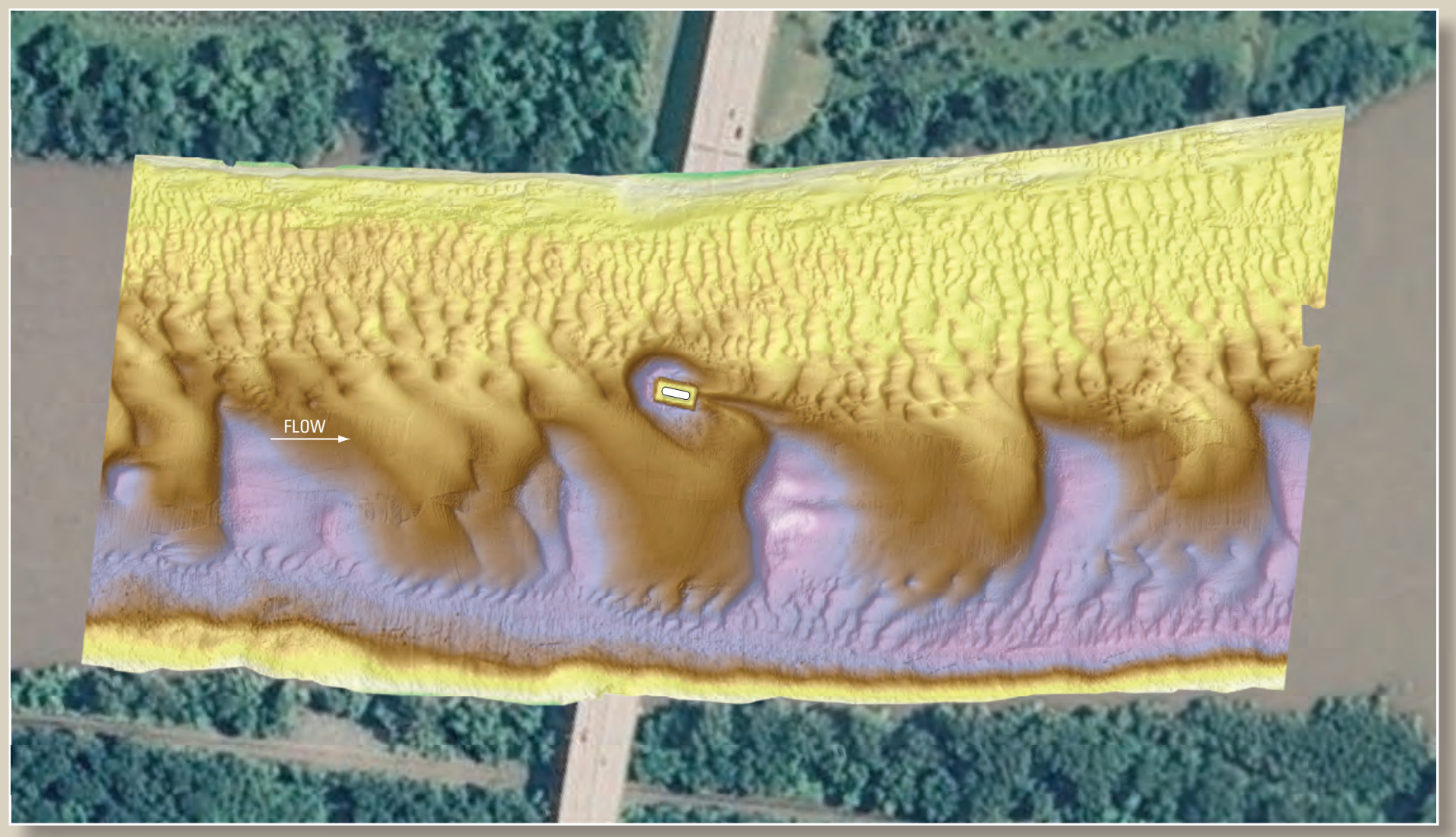

Scientific Investigations Report 2012-5204 
Cover. Front cover: Bathymetric survey of the Missouri River channel in the vicinity of structure A1800 on Interstate 635 in Kansas City, Missouri.

Back cover. Left: Point cloud visualization of the channel bed and right (west) side of pier 3 of structure L0098 on U.S. Highway 136 over the Missouri River at Brownville, Nebraska; right: Point cloud visualization of the channel bed and left (north) side of main channel pier 7 of structure A0767 on Interstate 435 over the Missouri River in Kansas City, Missouri. 


\section{Bathymetric and Velocimetric Surveys at Highway Bridges Crossing the Missouri River in and into Missouri during Summer Flooding, July-August 2011}

By Richard J. Huizinga

Prepared in cooperation with the Kansas and Missouri Departments of

Transportation

Scientific Investigations Report 2012-5204 


\section{U.S. Department of the Interior \\ KEN SALAZAR, Secretary \\ U.S. Geological Survey \\ Marcia K. McNutt, Director}

\section{U.S. Geological Survey, Reston, Virginia: 2012}

For more information on the USGS - the Federal source for science about the Earth, its natural and living resources, natural hazards, and the environment, visit http://www.usgs.gov or call 1-888-ASK-USGS.

For an overview of USGS information products, including maps, imagery, and publications, visit http://www.usgs.gov/pubprod

To order other USGS information products, visit http://store.usgs.gov

Any use of trade, firm, or product names is for descriptive purposes only and does not imply endorsement by the U.S. Government.

Although this information product, for the most part, is in the public domain, it also may contain copyrighted materials as noted in the text. Permission to reproduce copyrighted items must be secured from the copyright owner.

Suggested citation:

Huizinga, R.J., 2012, Bathymetric and velocimetric surveys at highway bridges crossing the Missouri River in and into Missouri during summer flooding, July-August 2011: U.S. Geological Survey Scientific Investigations Report 2012-5204, 166 p. 


\section{Contents}

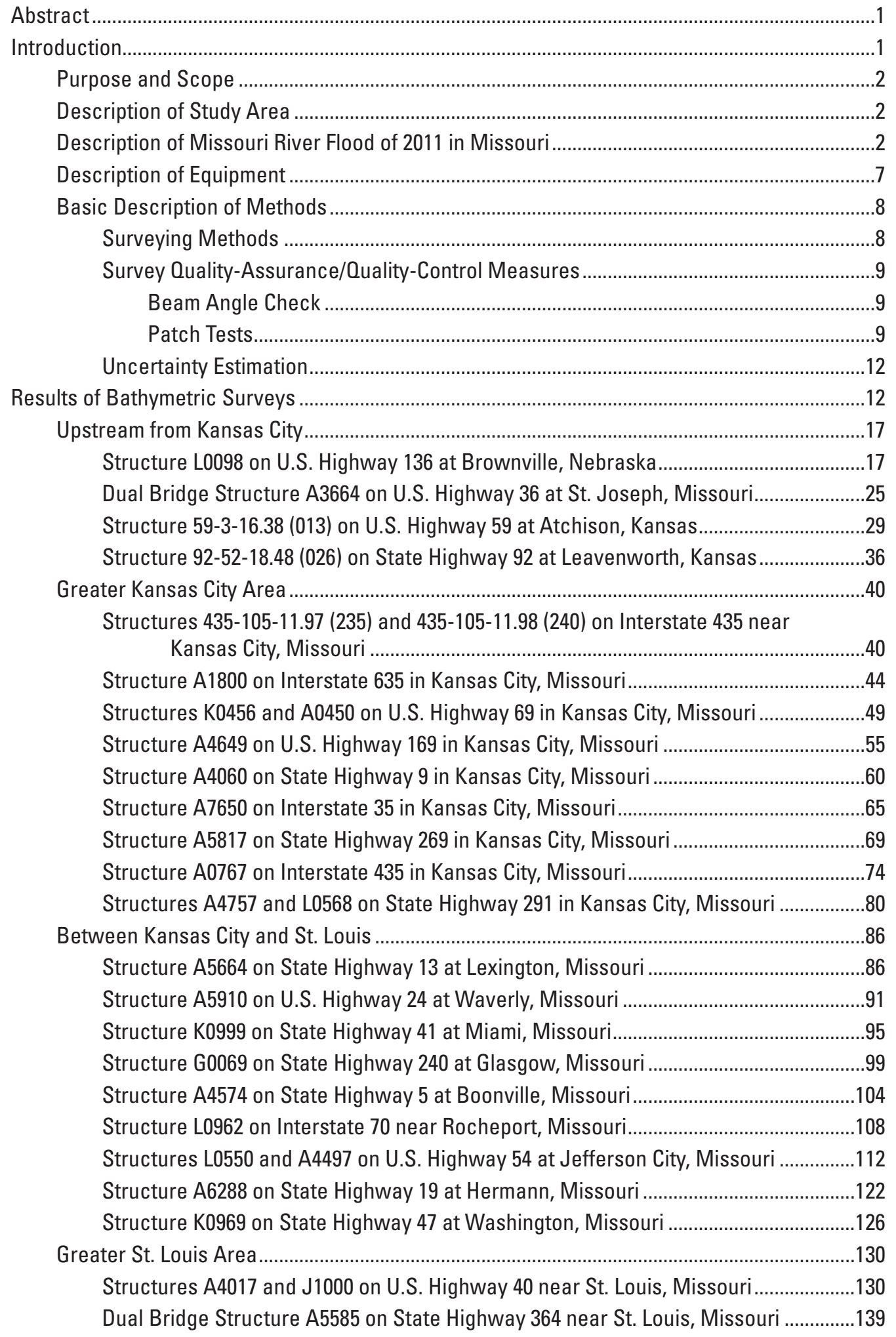


Structures A3292 and L0561 on Interstate 70 near St. Louis, Missouri..........................145

Dual Bridge Structure A4557 on State Highway 370 near St. Louis, Missouri ..............151

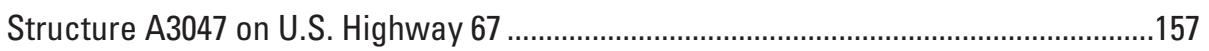

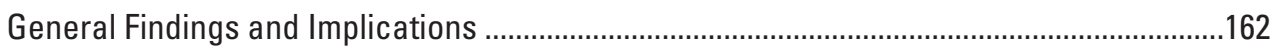

Effects of Moderate to High Flooding Compared to Previous Surveys ..........................162

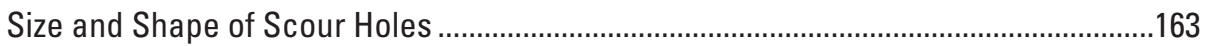

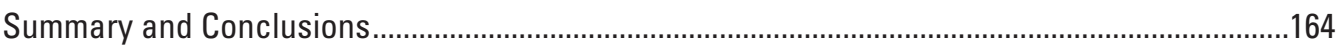

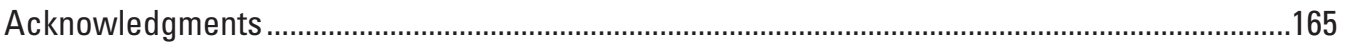

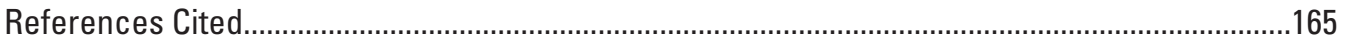

\section{Figures}

1. Map showing location of bathymetric surveys on the Missouri River channel conducted between July 13 and August 3, 2011

2. Graphs showing daily values of $A$, discharge, and $B$, gage height at selected streamflow-gaging stations on the Missouri River in Missouri, from April 1 to October 31, 2011.

3. Photograph showing the RESON SeaBat 7125-SV2 multibeam echo sounder, as viewed $A$, from the bottom, and $B$, mounted on the port side of the U.S. Geological Survey boat.

4. Diagram showing effects of $A$, timing offset for latency, and angular offsets for $B$, roll, $C$, pitch, and $D$, yaw on data from a multibeam echo sounder......

5. Map showing total propagated uncertainty of bathymetric data from the Missouri River channel in the vicinity of structure 59-3-16.38 (013) on U.S. Highway 59 at Atchison, Kansas

6. Map showing total propagated uncertainty of bathymetric data from the Missouri River channel in the vicinity of structures 435-105-11.97 (235) and 435-105-11.98 (240) on Interstate 435 near Kansas City, Missouri.

7. Map showing bathymetric survey of the Missouri River channel in the vicinity of structure L0098 on U.S. Highway 136 at Brownville, Nebraska..

8. Diagram showing key features, substructural and superstructural details, and surveyed channel bed of structure L0098 on U.S. Highway 136 over the Missouri River at Brownville, Nebraska.

9. Point cloud visualization of the channel bed and right (west) side of pier 3 of structure L0098 on U.S. Highway 136 over the Missouri River at Brownville, Nebraska

10. Map showing bathymetry and vertically averaged velocities of the Missouri River channel in the vicinity of structure L0098 on U.S. Highway 136 at Brownville, Nebraska

11. Map showing bathymetric survey of the Missouri River channel in the vicinity of dual bridge structure A3664 on U.S. Highway 36 at St. Joseph, Missouri.

12. Diagram showiing key features, substructural and superstructural details, and surveyed channel bed of dual bridge structure A3664 on U.S. Highway 36 over the Missouri River at St. Joseph, Missouri.

13. Map showing bathymetry and vertically averaged velocities of the Missouri River channel in the vicinity of dual bridge structure A3664 on U.S. Highway 36 at St. Joseph, Missouri 
14. Map showing bathymetric survey of the Missouri River channel in the vicinity of structure 59-3-16.38 (013) on U.S. Highway 59 at Atchison, Kansas ...

15. Diagram showing key features, substructural and superstructural details, and surveyed channel bed of structure 59-3-16.38 (013) on U.S. Highway 59 over the Missouri River at Atchison, Kansas.

16. Map showing difference between surfaces created from bathymetric surveys of the Missouri River channel in the vicinity of structure 59-3-16.38 (013) on U.S. Highway 59 at Atchison, Kansas, on June 30, 2009, and July 15, 2011.

17. Map showing difference between surfaces created from bathymetric surveys of the Missouri River channel in the vicinity of structure 59-3-16.38 (013) on U.S. Highway 59 at Atchison, Kansas, on June 30, 2010, and July 15, 2011

18. Map showing bathymetry and vertically averaged velocities of the Missouri River channel in the vicinity of structure 59-3-16.38 (013) on U.S. Highway 59 at Atchison, Kansas

19. Map showing bathymetric survey of the Missouri River channel in the vicinity of structure 92-52-18.48 (026) on State Highway 92 at Leavenworth, Kansas

20 Diagram showing key features, substructural and superstructural details, and surveyed channel bed of structure 92-52-18.48 (026) on State Highway 92 over the Missouri River at Leavenworth, Kansas.

21. Map showing bathymetry and vertically averaged velocities of the Missouri River channel in the vicinity of structure 92-52-18.48 (026) on State Highway 92 at Leavenworth, Kansas.

22. Map showing bathymetric survey of the Missouri River channel in the vicinity of structures 435-105-11.97 (235) and 435-105-11.98 (240) on Interstate 435 near Kansas City, Missouri.

23. Diagram showing key features, substructural and superstructural details, and surveyed channel bed of structures 435-105-11.97 (235) and 435-105-11.98 (240) on Interstate 435 over the Missouri River near Kansas City, Missouri

24. Map showing bathymetry and vertically averaged velocities of the Missouri River channel in the vicinity of structures 435-105-11.97 (235) and 435-105-11.98 (240) on Interstate 435 near Kansas City, Missouri

25. Map showing bathymetric survey of the Missouri River channel in the vicinity of structure A1800 on Interstate 635 in Kansas City, Missouri .

26. Diagram showing key features, substructural and superstructural details, and surveyed channel bed structure A1800 on Interstate 635 over the Missouri River in Kansas City, Missouri.

27. Map showing difference between surfaces created from bathymetric surveys of the Missouri River channel in the vicinity of structure A1800 on Interstate 635 in Kansas City, Missouri, on March 15, 2010, and July 16, 2011

28. Map showing bathymetry and vertically averaged velocities of the Missouri River channel in the vicinity of structure A1800 on Interstate 635 in Kansas City, Missouri.

29. Map showing bathymetric survey of the Missouri River channel in the vicinity of structures K0456 and A0450 on U.S. Highway 69 in Kansas City, Missouri.

30. Diagram showing key features, substructural and superstructural details, and surveyed channel bed of structure K0456 on U.S. Highway 69 over the Missouri River in Kansas City, Missouri

31. Diagram showing key features, substructural and superstructural details, and surveyed channel bed of structure A0450 on U.S. Highway 69 over the Missouri River in Kansas City, Missouri 
32. Map showing difference between surfaces created from bathymetric surveys of the Missouri River channel in the vicinity of structures K0456 and A0450 on U.S.

Highway 69 in Kansas City, Missouri, on March 15, 2010, and July 16, 2011

33. Map showing bathymetry and vertically averaged velocities of the Missouri River channel in the vicinity of structures K0456 and A0450 on U.S. Highway 69 in Kansas City, Missouri.

34. Map showing bathymetric survey of the Missouri River channel in the vicinity of structure A4649 on U.S. Highway 169 in Kansas City, Missouri.

35. Diagram showing key features, substructural and superstructural details, and surveyed channel bed of structure A4649 on U.S. Highway 169 over the Missouri River in Kansas City, Missouri

36. Map showing difference between surfaces created from bathymetric surveys of the Missouri River channel in the vicinity of structure A4649 on U.S. Highway 169 in Kansas City, Missouri, on March 16, 2010, and July 17, 2011

37. Map showing bathymetry and vertically-averaged velocities of the Missouri River channel in the vicinity of structure A4649 on U.S. Highway 169 in Kansas City, Missouri.

38. Map showing bathymetric survey of the Missouri River channel in the vicinity of structure A4060 on State Highway 9 in Kansas City, Missouri.

39. Diagram showing key features, substructural and superstructural details, and surveyed channel bed of structure A4060 on State Highway 9 over the Missouri River in Kansas City, Missouri

40. Map showing difference between surfaces created from bathymetric surveys of the Missouri River channel in the vicinity of structure A4060 on State Highway 9 in Kansas City, Missouri, on March 16, 2010, and July 17, 2011.

41. Map showing bathymetry and vertically averaged velocities of the Missouri River channel in the vicinity of structure A4060 on State Highway 9 in Kansas City, Missouri.

42. Map showing bathymetric survey of the Missouri River channel in the vicinity of structure A7650 on Interstate 35 in Kansas City, Missouri

43. Diagram showing key features, substructural and superstructural details, and surveyed channel bed of structure A7650 on Interstate 35 over the Missouri River in Kansas City, Missouri...

44. Map showing bathymetry and vertically averaged velocities of the Missouri River channel in the vicinity of structure A7650 on Interstate 35 in Kansas City, Missouri .....68

45. Map showing bathymetric survey of the Missouri River channel in the vicinity of structure A5817 on State Highway 269 in Kansas City, Missouri..

46. Diagram showing key features, substructural and superstructural details, and surveyed channel bed of structure A5817 on State Highway 269 over the Missouri River in Kansas City, Missouri

47. Map showing difference between surfaces created from bathymetric surveys of the Missouri River channel in the vicinity of structure A5817 on State Highway 269 in Kansas City, Missouri, on March 17, 2010, and July 18, 2011

48. Map showing bathymetry and vertically averaged velocities of the Missouri River channel in the vicinity of structure A5817 on State Highway 269 in Kansas City, Missouri.

49. Map showing bathymetric survey of the Missouri River channel in the vicinity of structure A0767 on Interstate 435 in Kansas City, Missouri 
50. Diagram showing key features, substructural and superstructural details, and surveyed channel bed of structure A0767 on Interstate 435 over the Missouri River in Kansas City, Missouri.

51. Point cloud visualization of the channel bed and left (north) side of main channel pier 7 of structure A0767 on Interstate $\mathbf{3 3 5}$ over the Missouri River in Kansas City, Missouri.

52. Map showing difference between surfaces created from bathymetric surveys of the Missouri River channel in the vicinity of structure A0767 on Interstate 435 in Kansas City, Missouri, on March 17, 2010, and July 18, 2011

53. Map showing bathymetry and vertically averaged velocities of the Missouri River channel in the vicinity of structure A0767 on Interstate 435 in Kansas City, Missouri ...79

54. Map showing bathymetric survey of the Missouri River channel in the vicinity of structures A4757 and L0568 on State Highway 291 in Kansas City, Missouri....

55. Diagram showing key features, substructural and superstructural details, and surveyed channel bed of structure A4757 on State Highway 291 over the Missouri River in Kansas City, Missouri

56. Diagram showing key features, substructural and superstructural details, and surveyed channel bed of structure L0568 on State Highway 291 over the Missouri River in Kansas City, Missouri

57. Map showing difference between surfaces created from bathymetric surveys of the Missouri River channel in the vicinity of structures A4757 and L0568 on State Highway 291 in Kansas City, Missouri, on March 18, 2010, and July 19, 2011

58. Map showing bathymetry and vertically averaged velocities of the Missouri River channel in the vicinity of structures A4757 and L0568 on State Highway 291 in Kansas City, Missouri.

59. Map showing bathymetric survey of the Missouri River channel in the vicinity of structure A5664 on State Highway 13 at Lexington, Missouri

60. Diagram showing key features, substructural and superstructural details, and surveyed channel bed of structure A5664 on State Highway 13 over the Missouri River at Lexington, Missouri

61. Map showing bathymetry and vertically averaged velocities of the Missouri River channel in the vicinity of structure A5664 on State Highway 13 at Lexington, Missouri.

62. Map showing bathymetric survey of the Missouri River channel in the vicinity of structure A5910 on U.S. Highway 24 at Waverly, Missouri.

63. Diagram showing key features, substructural and superstructural details, and surveyed channel bed of structure A5910 on U.S. Highway 24 over the Missouri River at Waverly, Missouri

64. Map showing bathymetry and vertically averaged velocities of the Missouri River channel in the vicinity of structure A5910 on U.S. Highway 24 at Waverly, Missouri.....94

65. Map showing bathymetric survey of the Missouri River channel in the vicinity of structure K0999 on State Highway 41 at Miami, Missouri....

66. Diagram showing key features, substructural and superstructural details, and surveyed channel bed of structure K0999 on State Highway 41 over the Missouri River at Miami, Missouri.

67. Map showing bathymetry and vertically averaged velocities of the Missouri River channel in the vicinity of structure K0999 on State Highway 41 at Miami, Missouri ......98

68. Map showing bathymetric survey of the Missouri River channel in the vicinity of structure G0069 on State Highway 240 at Glasgow, Missouri 
69. Diagram showing key features, substructural and superstructural details, and surveyed channel bed of structure G0069 on State Highway 240 over the Missouri River at Glasgow, Missouri 101

70. Point cloud visualization of the channel bed and right (west) side of main channel pier 2 of structure G0069 on State Highway 240 and the upstream railroad bridge pier over the Missouri River at Glasgow, Missouri.

71. Map showing bathymetry and vertically averaged velocities of the Missouri River channel in the vicinity of structure G0069 on State Highway 240 at Glasgow, Missouri 103

72. Map showing bathymetric survey of the Missouri River channel in the vicinity of structure A4574 on State Highway 5 at Boonville, Missouri

73. Diagram showing key features, substructural and superstructural details, and surveyed channel bed of structure A4574 on State Highway 5 over the Missouri River at Boonville, Missouri

74. Map showing bathymetry and vertically averaged velocities of the Missouri River channel in the vicinity of structure A4574 on State Highway 5 at Boonville, Missouri.

75. Map showing bathymetric survey of the Missouri River channel in the vicinity of structure L0962 on Interstate 70 near Rocheport, Missouri

76. Diagram showing key features, substructural and superstructural details, and surveyed channel bed of structure L0962 on Interstate 70 over the Missouri River near Rocheport, Missouri.

77. Map showing bathymetry and vertically averaged velocities of the Missouri River channel in the vicinity of structure L0962 on Interstate 70 near Rocheport, Missouri.

78. Map showing bathymetric survey of the Missouri River channel in the vicinity of structures L0550 and A4497 on U.S. Highway 54 at Jefferson City, Missouri

79. Diagram showing key features, substructural and superstructural details, and surveyed channel bed of structure L0550 on U.S. Highway 54 over the Missouri River at Jefferson City, Missouri.

80. Diagram showing key features, substructural and superstructural details, and surveyed channel bed of structure A4497 on U.S. Highway 54 over the Missouri River at Jefferson City, Missouri...

81. Map showing bathymetric surveys of the Missouri River channel in the vicinity of structures L0550 and A4497 on U.S. Highway 54 at Jefferson City, Missouri, on A, January 26, 2010, and B, March 1, 2011

82. Diagram showing design and approximate function of the channel-bed monitor at pier 4 of structure A4497 on U.S. Highway 54 over the Missouri River at Jefferson City, Missouri.

83. Map showing difference between surfaces created from bathymetric surveys of the Missouri River channel in the vicinity of structures L0550 and A4497 on U.S. Highway 54 at Jefferson City, Missouri, on January 26, 2010, and July 27, 2011

84. Map showing difference between surfaces created from bathymetric surveys of the Missouri River channel in the vicinity of structures L0550 and A4497 on U.S. Highway 54 at Jefferson City, Missouri, on March 1, 2011, and July 27, 2011.

85. Map showing bathymetry and vertically averaged velocities of the Missouri River channel in the vicinity of structures L0550 and A4497 on U.S. Highway 54 at Jefferson City, Missouri

86. Map showing bathymetric survey of the Missouri River channel in the vicinity of structure A6288 on State Highway 19 at Hermann, Missouri. 
87. Diagram showing key features, substructural and superstructural details, and surveyed channel bed of structure A6288 on State Highway 19 over the Missouri River at Hermann, Missouri

88. Map showing bathymetry and vertically averaged velocities of the Missouri River channel in the vicinity of structure A6288 on State Highway 19 at Hermann, Missouri.

89. Map showing bathymetric survey of the Missouri River channel in the vicinity of structure K0969 on State Highway 47 at Washington, Missouri..

90. Diagram showing key features, substructural and superstructural details, and surveyed channel bed of structure K0969 on State Highway 47 over the Missouri River at Washington, Missouri

91. Map showing bathymetry and vertically averaged velocities of the Missouri River channel in the vicinity of structure K0969 on State Highway 47 at Washington, Missouri...

92. Map showing bathymetric survey of the Missouri River channel in the vicinity of structures A4017 and J1000 on U.S. Highway 40 near St. Louis, Missouri...

93. Diagram showing key features, substructural and superstructural details, and surveyed channel bed of structure A4017 on U.S. Highway 40 over the Missouri River near St. Louis, Missouri.

94 Diagram showing key features, substructural and superstructural details, and surveyed channel bed of structure J1000 on U.S. Highway 40 over the Missouri River near St. Louis, Missouri.

95. Point cloud visualization of the channel bed and left (north) side of the central main channel piers (pier 5) of structures A4017 and J1000 on U.S. Highway 40 over the Missouri River near St. Louis, Missouri.

96. Map showing difference between surfaces created from bathymetric surveys of the Missouri River channel in the vicinity of structures A4017 and J1000 on U.S. Highway 40 near St. Louis, Missouri, on October 18, 2010, and July 29, 2011

97. Map showing bathymetry and vertically averaged velocities of the Missouri River channel in the vicinity of structures A4017 and J1000 on U.S. Highway 40 near St. Louis, Missouri.....

98. Map showing bathymetric survey of the Missouri River channel in the vicinity of dual bridge structure A5585 on State Highway 364 near St. Louis, Missouri.

99. Diagram showing key features, substructural and superstructural details, and surveyed channel bed along the upstream face of the upstream bridge of dual bridge structure A5585 on State Highway 364 over the Missouri River near St. Louis, Missouri.

100. Diagram showing key features, substructural and superstructural details, and surveyed channel bed along the upstream face of the downstream bridge of dual bridge structure A5585 on State Highway 364 over the Missouri River near St. Louis, Missouri

101. Map showing difference between surfaces created from bathymetric surveys of the Missouri River channel in the vicinity of dual bridge structure A5585 on State Highway 364 near St. Louis, Missouri, on October 21, 2010, and August 1, 2011

102. Map showing bathymetry and vertically averaged velocities of the Missouri River channel in the vicinity of dual bridge structure A5585 on State Highway 364 near St. Louis, Missouri

103. Map showing bathymetric survey of the Missouri River channel in the vicinity of structures A3292 and L0561 on Interstate 70 near St. Louis, Missouri 
104. Diagram showing key features, substructural and superstructural details, and surveyed channel bed of structure A3292 on Interstate 70 over the Missouri River near St. Louis, Missouri

105. Diagram showing key features, substructural and superstructural details, and surveyed channel bed of structure L0561 on Interstate 70 over the Missouri River near St. Louis, Missouri

106. Map showing difference between surfaces created from bathymetric surveys of the Missouri River channel in the vicinity of structures A3292 and L0561 on Interstate 70 near St. Louis, Missouri, on October 21, 2010, and August 2, 2011

107. Map showing bathymetry and vertically averaged velocities of the Missouri River channel in the vicinity of structures A3292 and L0561 on Interstate 70 near St. Louis, Missouri

108. Map showing bathymetric survey of the Missouri River channel in the vicinity of dual bridge structure A4557 on State Highway 370 near St. Louis, Missouri

109. Diagram showing key features, substructural and superstructural details, and surveyed channel bed along the upstream face of the upstream bridge of dual bridge structure A4557 on State Highway 370 over the Missouri River near St. Louis, Missouri

110. Diagram showing key features, substructural and superstructural details, and surveyed channel bed along the upstream face of the downstream bridge of dual bridge structure A4557 on State Highway 370 over the Missouri River near St. Louis, Missouri

111. Map showing difference between surfaces created from bathymetric surveys of the Missouri River channel in the vicinity of dual bridge structure A4557 on State Highway 370 near St. Louis, Missouri, on October 22, 2010, and August 2, 2011

112. Map showing bathymetry and vertically averaged velocities of the Missouri River channel in the vicinity of dual bridge structure A4557 on State Highway 370 near St. Louis, Missouri

113. Map showing bathymetric survey of the Missouri River channel in the vicinity of structure A3047 on U.S. Highway 67 near St. Louis, Missouri

114. Diagram showing key features, substructural and superstructural details, and surveyed channel bed of structure A3047 on U.S. Highway 67 over the Missouri River near St. Louis, Missouri

115. Map showing difference between surfaces created from bathymetric surveys of the Missouri River channel in the vicinity of structure A3047 on U.S. Highway 67 near St. Louis, Missouri, on October 25, 2010, and August 3, 2011

116. Map showing bathymetry and vertically averaged velocities of the Missouri River channel in the vicinity of structure A3047 on U.S. Highway 67 near St. Louis, Missouri 


\section{Tables}

1. Highway bridges crossing the Missouri River in and into Missouri, in downstream order......

2. Results of a beam angle check from two check lines over a reference surface at Longview Lake and Blue Springs Lake, Missouri, on July 6 and November 16, 2011, respectively

3. Results of patch tests performed at Longview Lake and Blue Springs Lake, Missouri, and on the Mississippi River at Alton, Illinois, before, during, and after surveying on the Missouri River in Missouri.

4. Total propagated uncertainty results for bathymetric data at a 1-meter grid spacing from surveys on the Missouri River in Missouri, from July 13 to August 3, 2011

5. Bridge and survey information, and selected channel-bed elevations from surveys on the Missouri River in Missouri, from July 13 to August 3, 2011.

6. Results near piers from surveys on the Missouri River in Missouri from Brownville, Nebraska, through Kansas City, Missouri, from July 13 to August 3, 2011

7. Summary information and bathymetric surface difference statistics from surveys on the Missouri River in Missouri from July 13 to August 3, 2011, and previous surveys for sites at which previous surveys have been done

8. Results near piers from surveys on the Missouri River in Missouri between Kansas City and St. Louis from July 13 to August 3, 2011

9. Results near piers from surveys on the Missouri River in Missouri near St. Louis, Missouri, from July 13 to August 3, 2011. 


\section{Conversion Factors}

\begin{tabular}{lcl}
\multicolumn{1}{c}{ Inch/Pound to SI } & \multicolumn{1}{c}{ Bultiply } & \multicolumn{1}{c}{ To obtain } \\
\hline & Length & \\
\hline inch (in.) & 2.54 & centimeter $(\mathrm{cm})$ \\
foot (ft) & 0.3048 & meter $(\mathrm{m})$ \\
mile (mi) & 1.609 & kilometer $(\mathrm{km})$ \\
\hline & Flow rate & \\
\hline foot per second $(\mathrm{ft} / \mathrm{s})$ & 0.3048 & meter per second $(\mathrm{m} / \mathrm{s})$ \\
cubic foot per second $\left(\mathrm{ft}^{3} / \mathrm{s}\right)$ & 0.02832 & cubic meter per second $\left(\mathrm{m}^{3} / \mathrm{s}\right)$ \\
\hline
\end{tabular}

Vertical coordinate information is referenced to the North American Vertical Datum of 1988 (NAVD 88).

Horizontal coordinate information is referenced to the North American Datum of 1983 (NAD 83).

In this report, the words "left" and "right" generally refer to directions that would be reported by an observer facing downstream. 


\title{
Bathymetric and Velocimetric Surveys at Highway Bridges Crossing the Missouri River in and into Missouri during Summer Flooding, July-August 2011
}

\author{
By Richard J. Huizinga
}

\section{Abstract}

Bathymetric and velocimetric surveys were conducted by the U.S. Geological Survey, in cooperation with the Kansas and Missouri Departments of Transportation, in the vicinity of 36 bridges at 27 highway crossings of the Missouri River between Brownville, Nebraska and St. Louis, Missouri, from July 13 through August 3, 2011, during a summer flood. A multibeam echo sounder mapping system was used to obtain channel-bed elevations for river reaches ranging from 1,350 to 1,860 feet and extending across the active channel of the Missouri River. These bathymetric scans provide a "snapshot" of the channel conditions at the time of the surveys and provide characteristics of scour holes that may be useful in the development of predictive guidelines or equations for scour holes. These data also may be used by the Kansas and Missouri Departments of Transportation to assess the bridges for stability and integrity issues with respect to bridge scour during floods.

Bathymetric data were collected around every pier that was in water, except those at the edge of water, in extremely shallow water, or surrounded by debris rafts. Scour holes were present at most piers for which bathymetry could be obtained, except at piers on channel banks, those near or embedded in lateral or longitudinal spur dikes, and those on exposed bedrock outcrops. Scour holes observed at the surveyed bridges were examined with respect to depth and shape. Although exposure of parts of foundational support elements was observed at several piers, at most sites the exposure likely can be considered minimal compared to the overall substructure that remains buried in bed material; however, there were several notable exceptions where the bed material thickness between the bottom of the scour hole and bedrock was less than 6 feet. Such substantial exposure of usually buried substructural elements may warrant special observation in future flood events.

Previous bathymetric surveys had been done at several of the sites, and comparisons between bathymetric surfaces from the previous surveys and those of this study indicate substantial variability in the response of the channel bed to the 2011 summer flood conditions. At sites in Kansas City, there was no consistent deepening of the channel or increase in the size of scour holes, despite substantially more discharge and a higher water-surface elevation in the 2011 surveys, which implies the high-flow conditions during the 2011 surveys created a similar scour scenario to the previous surveys. At Jefferson City and the St. Louis sites, there was a consistent deepening of the channel, and a slight to substantial increase in the depth of scour holes in the 2011 surveys compared to previous surveys, although the effects of the higher flow appeared to be mitigated by the shape and alignment of the piers at most sites in St. Louis. Construction activities related to a new bridge at the Atchison, Kansas, site likely have contributed to the substantial additional scour observed there in a previous survey during the 2010 flooding, and the subsequent aggradation of the channel bed observed in the 2011 survey. Pier size, nose shape, and alignment to flow also had a profound effect on the size of the scour hole observed for a given pier.

\section{Introduction}

Scour in alluvial channels is the removal of channel bed and bank material by flowing water, and is the leading cause of bridge failures in the United States (Richardson and Davis, 2001). Scour at a bridge site is the result of short- and longterm geomorphic processes and the local effects caused by elements of the structure in or adjacent to the waterway (Richardson and Davis, 2001; Huizinga and Rydlund, 2004). Because the effects of scour can be severe and dangerous, bridges and other structures over waterways are routinely assessed and inspected. Scour processes can be exacerbated during highflow conditions.

The Kansas Department of Transportation (KDOT) and the Missouri Department of Transportation (MoDOT) are responsible for most of the transportation infrastructure of each State. A part of this responsibility is fulfilled through periodic inspections of highway structures, including bridges that span waterways. At most of these structures, all or most of the structure can be fully inspected from land or from 
personnel lift trucks deployed from the roadway of the structure; however, for structures over major waterways, such as the Missouri River, inspection of the part of the bridge that is underwater requires a different approach.

The U.S. Geological Survey (USGS), in cooperation with MoDOT, began assessing scour at waterway crossings throughout the state in 1991 (Huizinga and Rydlund, 2004). In 2007, the USGS, in cooperation with MoDOT, began determining channel bathymetry and monitoring bridges for scour using single-beam echo sounders and a multibeam mapping system (Rydlund, 2009; Huizinga, 2010, 2011; Huizinga and others, 2010). In particular, the multibeam mapping system has proven to be a useful tool not only in determining channel bathymetry, but also in providing medium- to high-resolution imagery of bridge structural elements below the water line. In 2010 the USGS, in cooperation with MoDOT, began conducting a series of bathymetric surveys at various highway bridges across major waterways in Missouri. In March 2010, 9 highway bridges at 7 crossings over the Missouri River in Kansas City, Missouri, were assessed using the multibeam mapping system (Huizinga, 2010), and in October 2010, 12 highway bridges at 7 crossings over the Missouri and Mississippi Rivers near St. Louis, Missouri, were assessed (Huizinga, 2011). Because high-flow conditions began on the Missouri River during June and were predicted to extend through August, MoDOT and KDOT became especially interested in the condition of the channel bed in the vicinity of the various highway bridges that span the river, and a study was conducted in cooperation with the USGS.

There are 37 highway bridges at 28 unique sites that span the Missouri River in Missouri. (fig. 1; table 1). Of these 37 highway bridges, 26 connect adjacent counties within the state of Missouri, 9 connect Missouri with Kansas, and 2 connect Missouri with Nebraska (fig. 1). MoDOT is responsible for the 26 highway bridges that connect adjacent counties in Missouri, as well as 6 of the 11 bridges that connect Missouri with Kansas and Nebraska; KDOT and the Nebraska Department of Roads are responsible for the remaining 5 bridges (table 1). Several of the highway bridges are in a dual bridge configuration, consisting of two bridges with the same structure number; furthermore, several sites consist of two bridges, each with separate structure numbers. All of the highway bridges spanning the Missouri River in Missouri were examined as part of this assessment, except the bridge at Rulo, Nebraska, resulting in surveys at 36 highway bridges at 27 unique crossings of the Missouri River in Missouri (table 1). Several railroad bridges also were surveyed as part of this study because of their proximity to the highway bridges, but will be discussed only incidentally in this report.

\section{Purpose and Scope}

The purpose of this report is to document bathymetric and velocimetric surveys of the Missouri River channel in the vicinity of 36 highway bridges at 27 crossings of the river in Missouri, using a multibeam echo sounder and an acoustic Doppler current profiler during the summer flooding that occurred in 2011. Equipment and methods used and results obtained are described. The results obtained from the bathymetric and velocimetric surveys of the channel provide a "snapshot" of the channel-bed conditions at the time of the surveys and provide characteristics of scour holes that may be useful in developing predictive guidelines or equations for scour holes. These data also may be used by KDOT and MoDOT to assess the bridges for stability and integrity issues with respect to bridge scour.

\section{Description of Study Area}

The overall study area for this report is 550 miles of the Lower Missouri River (fig. 1). Starting from the northwest corner of Missouri, the Missouri River flows south from Iowa along the border between Nebraska and Missouri, and continues along the border between Kansas and Missouri to the greater Kansas City area (fig. 1). From Kansas City, the Missouri River flows generally eastward to the greater St. Louis area, joining the Mississippi River north of downtown St. Louis, Missouri (fig. 1). All of the highway crossings on the Missouri River between Brownville, Nebraska, and St. Louis, Missouri, were examined as part of this study, with the exception of the crossing at Rulo, Nebraska.

\section{Description of Missouri River Flood of 2011 in Missouri}

The Missouri River was in flood conditions when the bathymetric surveys were performed. Widespread abovenormal or record rainfall combined with later-than-normal, rapid melting of a record snowpack in the northern Rockies and Northern Plains resulted in major flooding in the Missouri River basin (Holmes and others, 2012; National Oceanic and Atmospheric Administration, 2012b). The six U.S. Army Corps of Engineers reservoirs along the Missouri River in Montana, North Dakota, and South Dakota (fig. 1) were at record high levels and sustained record releases from mid-June to early August (National Oceanic and Atmospheric Administration, 2012b). The most downstream reservoir is located about 160 miles upstream from the survey area.

Despite the record releases from the upstream reservoirs, the behavior of the flood hydrograph of the Missouri River in Missouri was profoundly affected by the lack of substantial rainfall throughout the summer in Missouri (National Oceanic and Atmospheric Administration, 2012a). Spring rains throughout the Missouri River basin caused increased discharge on the Missouri River in April and May, and discharge increased downstream with contributing drainage area, albeit non-uniformly because of the distribution of rainfall on the various contributing drainages (fig. $2 A$ ); however, despite the large volume of water coming from the upstream reservoirs, most of the various tributary basins to the Missouri River in 


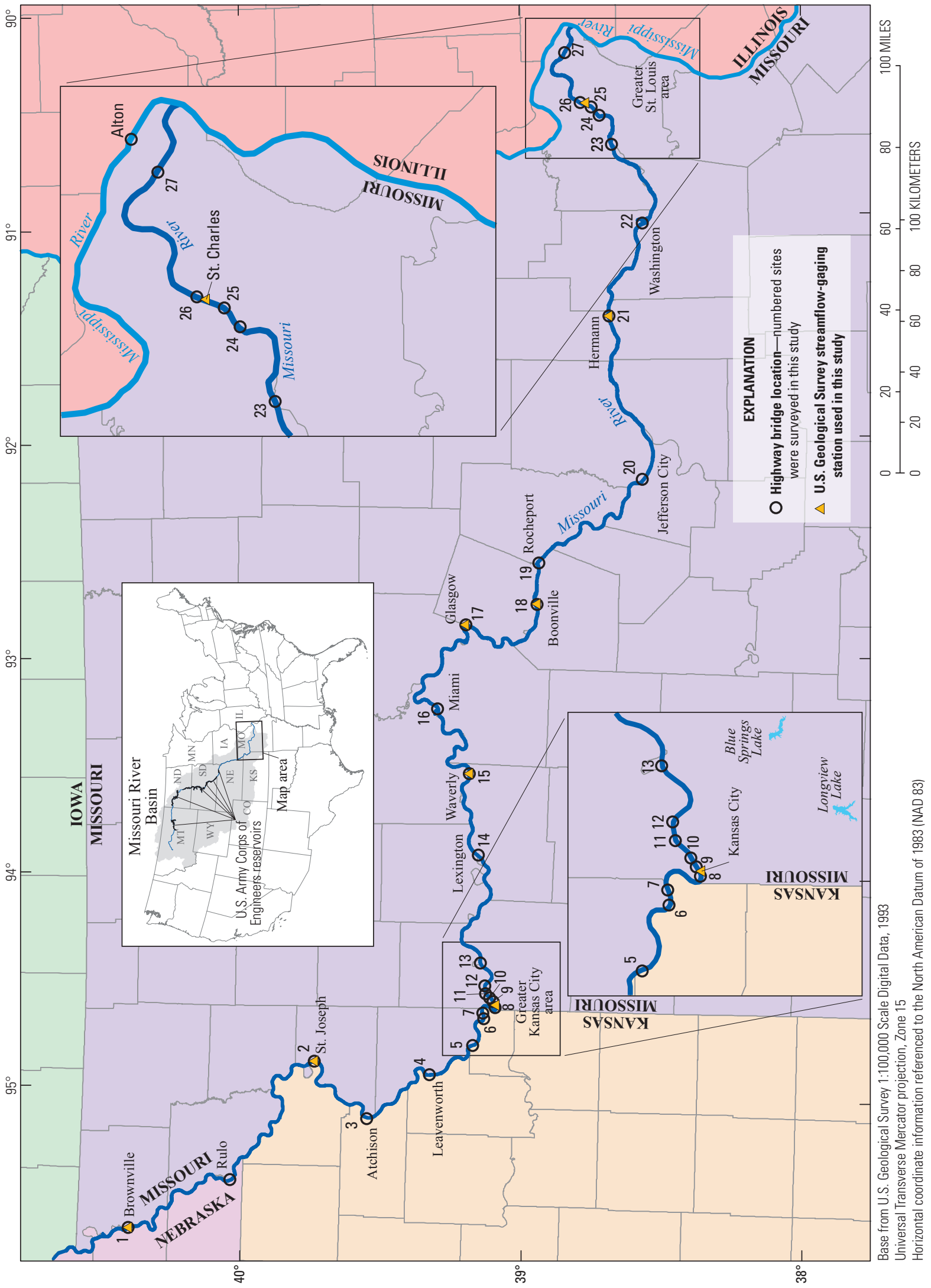

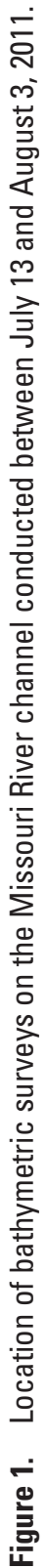




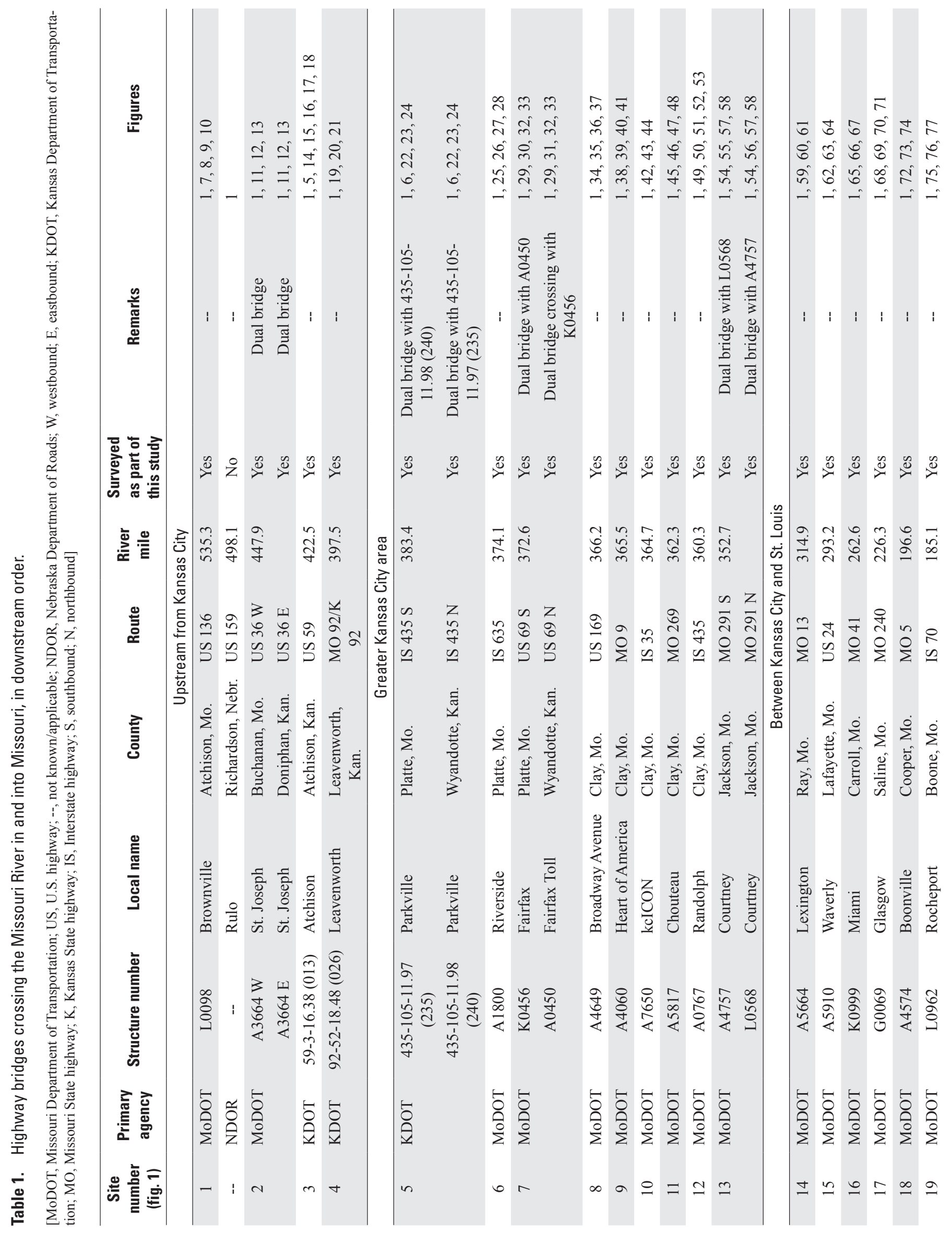




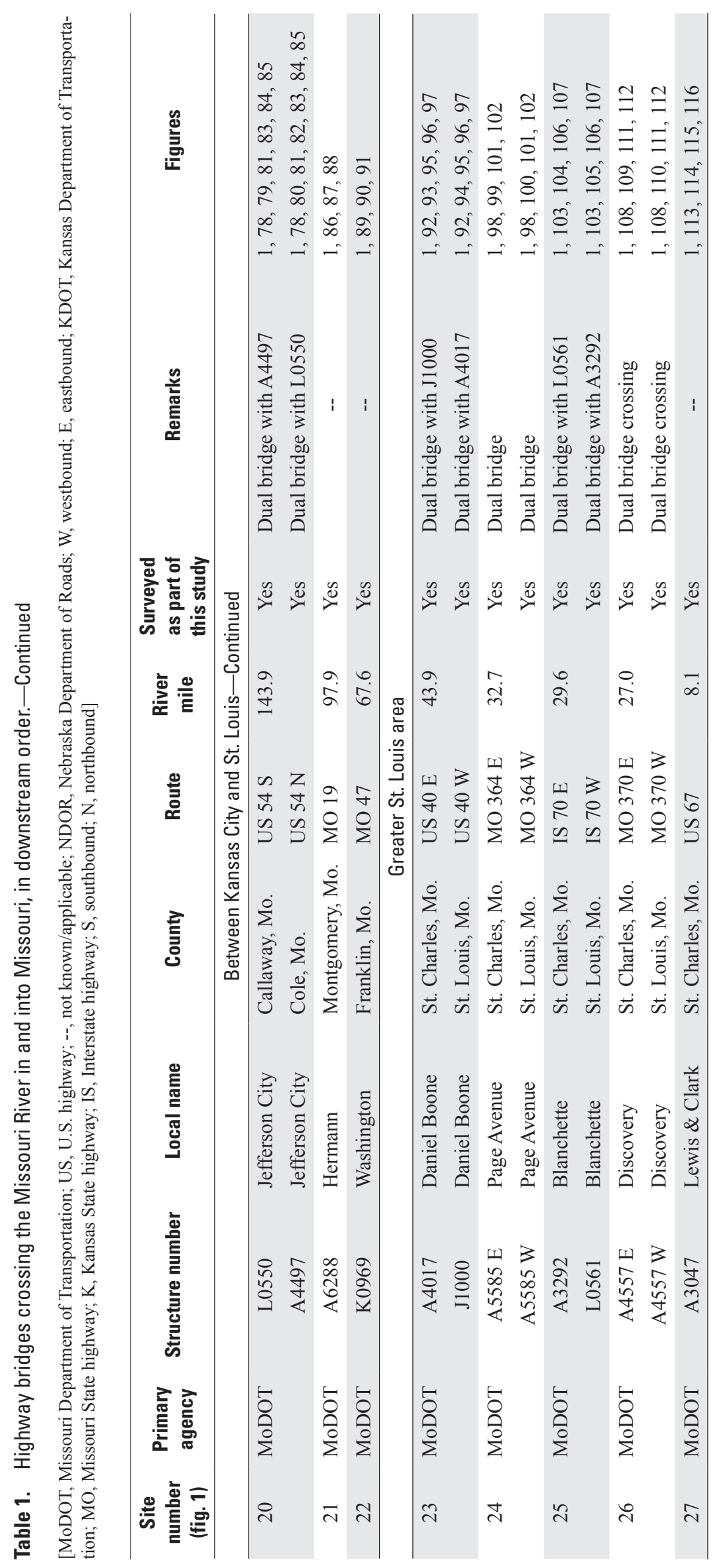



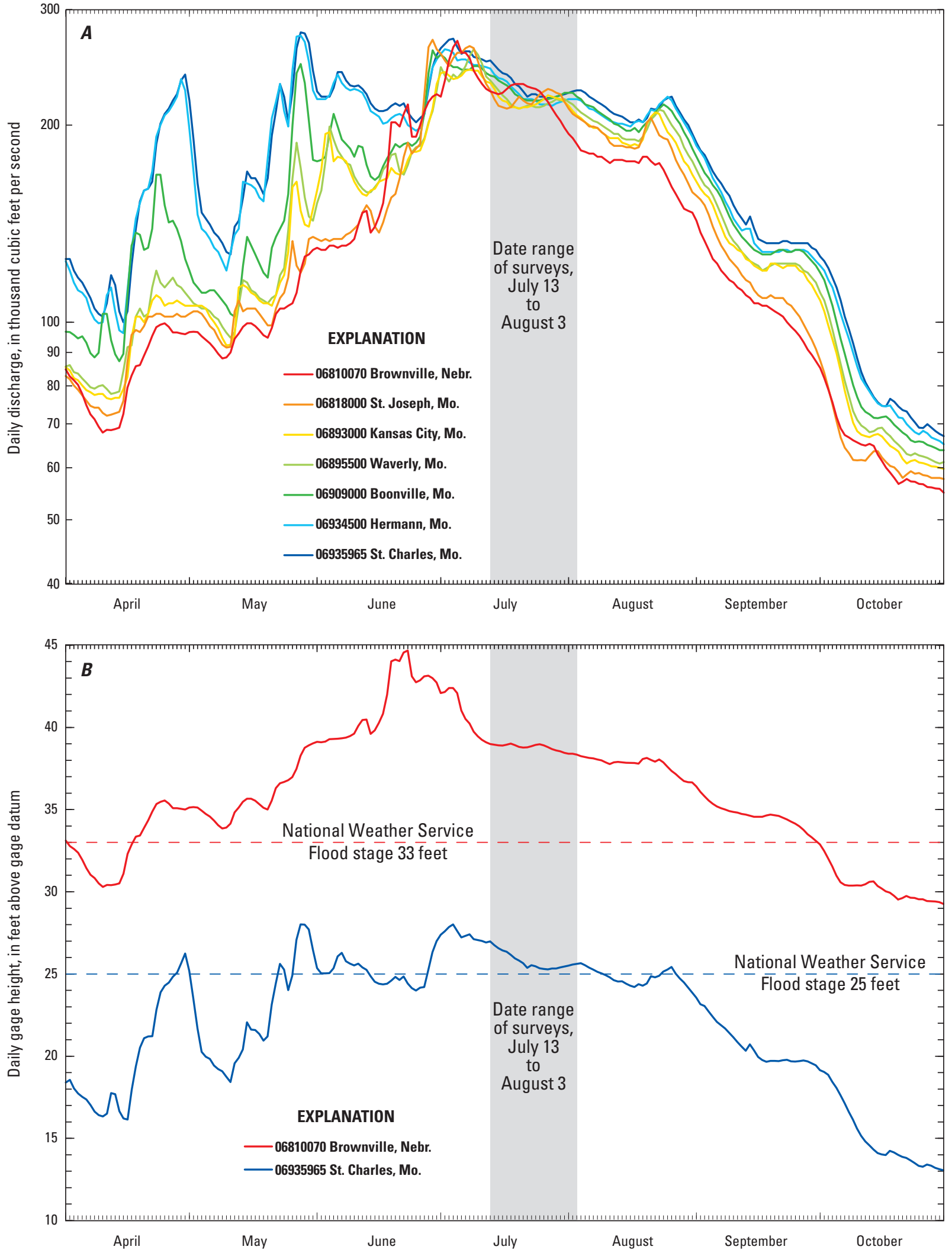

Figure 2. Daily values of $A$, discharge, and $B$, gage height at selected streamflow-gaging stations on the Missouri River in Missouri, from April 1 to October 31, 2011. 
Missouri received minimal rain from late June through July (National Oceanic and Atmospheric Administration, 2012a). Therefore, the discharge remained relatively constant as the summer flood wave moved downstream in the basin, as compared to the spring flood (fig. $2 A$ ).

Correspondingly, the magnitude of the flood decreased downstream from the major source of floodwaters (the upstream reservoirs) as the channel capacity increased in a downstream direction. For example, discharges at the various streamflow-gaging stations (hereinafter referred to as "streamgages") were greater than 90,000 cubic feet per second $\left(\mathrm{ft}^{3} / \mathrm{s}\right)$ for approximately the same amount of time (fig. $2 A$ ); however, the stage from a flow of $90,000 \mathrm{ft}^{3} / \mathrm{s}$ results in more overbank flooding at Brownville, Nebraska, than at St. Charles, Missouri. At Brownville, Nebraska, the Missouri River stage was greater than National Weather Service (NWS) flood stage continuously for more than 23 weeks, from April 18 to September 30 (fig. $2 B$ ), whereas at St. Charles, Missouri, the Missouri River stage was greater than NWS flood stage only intermittently from April through mid-June, and continuously from June 28 until August 9, or about 6 weeks (fig. 2B). Similarly, the water level at Brownville was substantially higher than the bank elevation for most of the period from mid-April to late September and resulted in closure of U.S. Highway 136 for much of the summer, whereas at St. Charles, the water was only slightly higher than the bank elevation at the peak of the flooding.

During the time of the bathymetric scans from July 13 to August 3, 2011, the discharge ranged from 187,000 to $231,000 \mathrm{ft}^{3} / \mathrm{s}$ at the USGS streamgage on the Missouri River at Brownville, Nebraska (station 06810070; figs. 1, 2; U.S. Geological Survey, 2012). This discharge range has a daily exceedance of less than 5 percent (U.S. Geological Survey, 2003), and is between the 5-percent and 1.3-percent annual exceedance probability (20-year and 75 -year recurrence interval, respectively) flood discharges of $181,800 \mathrm{ft}^{3} / \mathrm{s}$ and $232,900 \mathrm{ft}^{3} / \mathrm{s}$, respectively (U.S. Army Corps of Engineers, 2004a). During the same timeframe at the USGS streamgage on the Missouri River at St. Charles, Missouri (station 06935965; fig. 1; U.S. Geological Survey, 2012), the discharge ranged from 220,000 to $251,000 \mathrm{ft}^{3} / \mathrm{s}$ (fig. 2). This discharge range also has a daily exceedance of less than 5 percent (U.S. Geological Survey, 2003), but is near the 50-percent annual exceedance probability (2-year recurrence interval) flood discharge of 250,000 ftº (U.S. Army Corps of Engineers, 2004b).

\section{Description of Equipment}

The bathymetry of the Missouri River at each of the bridges was determined using a high-resolution multibeam mapping system. The various components of the multibeam mapping system used for this study are the next generation of the equipment used in similar studies at various bridges on the Missouri River in Kansas City, Missouri (Huizinga, 2010), and on the Missouri and Mississippi Rivers near St. Louis, Missouri (Huizinga, 2011). The survey methods used to obtain the data were similar to these previous studies, as were the measures used to ensure data quality. A brief description of the equipment follows; a complete description of the various system components and methods used in this study is available in the previous report by Huizinga (2010).

A multibeam mapping system is an integration of several individual components: the multibeam echo sounder (MBES), a navigation and motion-sensing system, and a data-collection and processing computer. The MBES that was used is the RESON SeaBat ${ }^{\mathrm{TM}}$ 7125-SV2 (fig. 3), operated at a frequency of 400 kilohertz $(\mathrm{kHz})$. The RESON SeaBat ${ }^{\mathrm{TM}} 7125-\mathrm{SV} 2$ is an updated version of the RESON SeaBat ${ }^{\mathrm{TM}} 7125$ used in previous studies (Huizinga, 2010, 2011; Huizinga and others, 2010) with similar features and functions, but with a more streamlined sonar head, and stiffer, more compact head tilt bracket (fig. 3). The navigation and motion-sensing system that was used is the Applanix Position Orientation Solution for Marine Vessels (POS MV ${ }^{\mathrm{TM}}$ ) WaveMaster system (hereinafter referred to as "the POS"). The navigation system locates the MBES in three-dimensional space, and the motion-sensing system measures the heave, pitch, roll, and heading of the vessel (and, thereby, the MBES) to accurately position the data received by the MBES.

Two methods were used to provide real-time kinetic (RTK) differential corrections to the POS for the navigation and tide solution during the survey. For all but the last four sites, a Global Positioning System (GPS) base station was set up on the river bank, near the bridge to be surveyed as in previous studies (Huizinga, 2010, 2011; Huizinga and others, 2010). For the last four sites surveyed, the Virtual Realtime Station (VRS) network, established and maintained by MoDOT, was used to provide the RTK differential corrections to the POS.

With either method, the bridge structure blocked a part of or the whole signal from the GPS constellation of satellites when the survey vessel was near or under a bridge, resulting in a GPS outage that had the potential to degrade the positional accuracy of the vessel until such time as an RTKfixed navigation solution was re-acquired; however, as in the Kansas City and St. Louis studies (Huizinga, 2010, 2011), the navigation information from the survey was post-processed using the POS-Pac ${ }^{\mathrm{TM}}$ Mobile Mapping Suite $\left(\mathrm{MMS}^{\mathrm{TM}}\right.$ ) software (Applanix Corporation, 2009), which provided tools to identify and compensate for sensor and environmental errors, and computes an optimally blended navigation solution from the GPS and inertial motion unit (IMU) raw data. The blended navigation solution (called a "standard best-estimate of travel" or "SBET" file), generated by post-processing the navigation data, was applied to the whole survey at a given bridge to minimize the effects of the GPS outages while surveying under the bridges.

The data from the MBES and navigation and motionsensing components were processed and integrated into a cohesive dataset for cleanup and visualization. A computer 

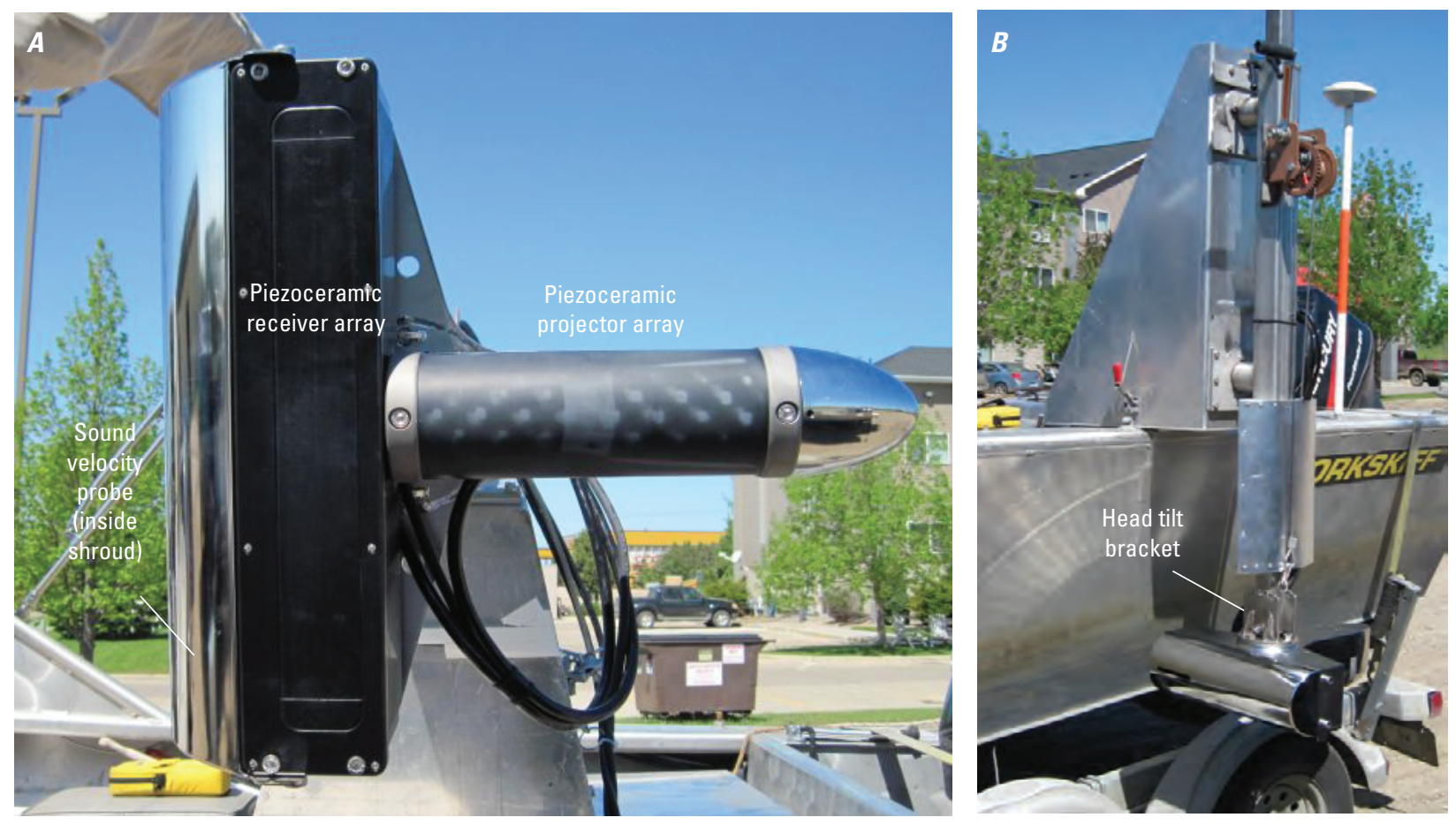

Figure 3. The RESON SeaBat 7125-SV2 multibeam echo sounder, as viewed $A$, from the bottom, and $B$, mounted on the port side of the U.S. Geological Survey boat.

onboard the survey boat ran the HYPACK ${ }^{\circledR} /$ HYSWEEP $^{\circledR}$ data acquisition software (HYPACK, Inc., 2011), which was used to prepare for the bathymetric surveys and collect the survey data. Upon completion of the surveys, the acquired depth data were further processed to remove data spikes and other spurious points in the multibeam swath trace, were georeferenced using the navigation and position solution data from the SBET file from POS-Pac ${ }^{\mathrm{TM}} \mathrm{MMS}^{\mathrm{TM}}$, and were visualized in HYPACK $^{\circledR} /$ HYSWEEP $^{\circledR}$ as a triangulated irregular network (TIN) surface or a point cloud. The georeferenced data were output to a comma-delimited file either with no data reduction, or filtered and reduced based on a desired data resolution. These comma-delimited data were compiled into a geographic information system (GIS) database for each site using the ArcGIS package (Environmental Systems Research Institute, 2010).

Information about the velocity of the river at various points throughout the study reach were obtained by means of an acoustic Doppler current profiler (ADCP), as was done in the study by Huizinga and others (2010). A Teledyne RD Instruments Rio Grande ADCP operating at $600 \mathrm{kHz}$ was used to obtain velocities at 1.64 feet (ft; 0.5 -meter) increments, or "bins," throughout the water column. The Rio Grande ADCP operates in depths from 2.3 to $245 \mathrm{ft}$, and determines the velocity of the water by measuring the Doppler shift of an acoustic signal reflected from various particles suspended in the water (Mueller and Wagner, 2009). By measuring the
Doppler shift in four different beam directions, the velocity of the water in each bin can be determined in three dimensions.

\section{Basic Description of Methods}

The methods used to acquire and assure the collection of quality data were the same as those used in previous studies with the MBES (Huizinga, 2010, 2011; Huizinga and others, 2010), and the reader is referred to those reports for the details of the methods used. A brief summary of and differences from these methods are highlighted below.

\section{Surveying Methods}

The size of the surveyed area at each site was dictated somewhat by the flow conditions. Because of the moderate- to high-flow conditions on the Missouri River during the survey dates (July 13 through August 3, 2011), many of the lateral and longitudinal spur dikes were submerged, making it possible to survey from bank to bank as had been done in the previous Kansas City study (Huizinga, 2010). The surveyed areas were approximately 1,640 ft long in the direction of flow, positioned so that the surveyed highway bridges were approximately one-third to one-half of the total length from the upstream boundary. The upstream and downstream boundaries of the surveyed areas were assumed to be beyond the hydraulic effect of the bridge structures. 
As in previous studies, bathymetric data were obtained along longitudinal transect lines, and each survey was designed so that there was overlap of the survey swaths to ensure complete coverage of the channel bed and minimize sonic "shadows." Substantial overlap was achieved for many of the surveyed swaths, except in shallow areas near the channel banks or spur dikes, or near debris rafts. To minimize data acquisition times in the shallows, data gaps were left between the swaths. The presence of debris rafts made surveying difficult or impossible in some areas.

After completion of the bathymetric survey with the MBES at a given site, the velocity data were obtained with the $\mathrm{ADCP}$ on as many as seven lateral transects across the channel within the study area. The distance between the velocity transect lines was about $260 \mathrm{ft}$, with three transects upstream and four transects downstream from the bridge in question. Each transect line was traversed two times, once in each direction across the river. The reported velocity values are the average from the two traverses.

\section{Survey Quality-Assurance/Quality-Control Measures}

A quality-assurance plan has been established for discharge measurements using ADCPs, including several instrument diagnostic checks and calibrations. These standard operating procedures were followed when acquiring the velocity profile data for these surveys. For a detailed discussion of these procedures, see Oberg and others (2005).

For the MBES mapping system, the principal qualityassurance assessments were performed in real time during the survey. The MBES operator continuously was assessing the quality of the collected data during the survey, making visual observations of across-track swaths (such as convex, concave, or skewed bed returns in flat, smooth bottoms), noting data quality flags and alarms from the MBES and the POS, and noting comparisons between adjacent overlapping swaths. In addition to the real-time quality-assurance assessments during the survey, several tests were performed to ensure the data quality acquired by the MBES mapping system. For this survey, beam angle checks and a suite of patch tests were performed to ensure quality data were acquired from the MBES mapping system.

\section{Beam Angle Check}

A beam angle check is used to determine the accuracy of the depth readings obtained by the outer beams of the MBES (U.S. Army Corps of Engineers, 2004c). The HYPACK ${ }^{\circledR /}$ HYSWEEP $^{\circledR}$ software has a program that performs a statistical assessment of the quality of the outer beams compared to a reference surface. Before the surveys, on July 6, 2011, a reference surface was created for a part of Longview Lake near Kansas City, Missouri, and check lines were run across the reference surface. The results of this beam angle check (table 2) were within the recommended standards utilized by the U.S. Army Corps of Engineers for hydrographic surveys for all angles less than 60 degrees from nadir (U.S. Army Corps of Engineers, 2004c). Upon closer scrutiny, however, the reference surface was determined to be non-uniform in elevation, compromising the integrity of the beam angle check (U.S. Army Corps of Engineers, 2004c). Therefore, a second beam angle check was performed after the surveys (November 16, 2011) using the reference surface on Blue Springs Lake near Kansas City, Missouri, that had been used for beam angle checks for the previous Kansas City and St. Louis surveys (Huizinga, 2010, 2011). The results of the second beam angle check (table 2) were within the recommended standards utilized by the U.S. Army Corps of Engineers for hydrographic surveys for all angles less than 70 degrees from nadir (U.S. Army Corps of Engineers, 2004c), permitting the use of the full sonar swath.

\section{Patch Tests}

Patch tests are a series of dynamic calibration tests that are used to check for subtle variations in the orientation and timing of the MBES with respect to the POS and real-world coordinates. The patch tests are used to determine timing offsets caused by latency between the MBES and the POS, and angular offsets to roll, pitch, and yaw caused by the alignment of the transducer head (fig. 4). These offsets are assumed to be constants for a given survey, barring an event that causes the mount to change, such as striking a submerged object. The offsets determined in the patch test are applied when processing the data collected during a given survey.

Patch tests were done every day of surveying in previous studies (Huizinga, 2010, 2011), yet offset values remained almost constant, except when notable events occurred that caused the mount to bend (see table 3 in Huizinga, 2010). Given the relative consistency of the offset values observed in the previous studies, the additional time required to obtain and process patch test data every day was deemed unwarranted. Therefore, patch tests were performed only four times before, during, and after the surveys; three of the tests were performed on lakes near Kansas City, Missouri, and one was performed on the Mississippi River at Alton, Illinois (table 3). The test performed on the Mississippi River was after the MBES unit struck a substantial submerged log while surveying at structures A3292 and L0561 on Interstate 70 near St. Louis, Missouri, (site 25; fig. 1) on August 2, 2011, causing the mount to bend.

Initially, the results obtained from the test on the Mississippi River were substantially different from the tests on the lakes and could have been the result of striking the submerged log; however, the sites surveyed after striking the log that were processed with the offset values determined from the Mississippi River patch tests appeared to have alignment artifacts that typically result from application of erroneous offsets. Offset values obtained from the lake test performed in November as part of another study (Richard Huizinga, U.S. Geological Survey, unpub. data, 2012) were more consistent with 
Table 2. Results of a beam angle check from two check lines over a reference surface at Longview Lake and Blue Springs Lake, Missouri, on July 6 and November 16, 2011, respectively.

$[<$, less than; --, no data; deg, degrees]

\begin{tabular}{|c|c|c|c|c|c|c|c|c|}
\hline \multirow{2}{*}{$\begin{array}{c}\begin{array}{c}\text { Beam } \\
\text { angle } \\
\text { limit }\end{array} \\
\text { (degrees) }\end{array}$} & \multicolumn{2}{|c|}{$\begin{array}{l}\text { Maximum outlier, } \\
\text { in feet }\end{array}$} & \multicolumn{2}{|c|}{$\begin{array}{l}\text { Mean difference, } \\
\text { in feet }\end{array}$} & \multicolumn{2}{|c|}{$\begin{array}{c}\text { Standard deviation, } \\
\text { in feet }\end{array}$} & \multicolumn{2}{|c|}{$\begin{array}{l}\text { 95-percent confidence, } \\
\text { in feet }\end{array}$} \\
\hline & $07 / 06 / 11$ & $11 / 16 / 11$ & $07 / 06 / 11$ & $11 / 16 / 11$ & $07 / 06 / 11$ & $11 / 16 / 11$ & $07 / 06 / 11$ & $11 / 16 / 11$ \\
\hline 20 & 0.56 & 0.17 & 0.03 & 0.01 & 0.10 & 0.03 & 0.23 & 0.06 \\
\hline 25 & 0.56 & 0.14 & 0.03 & 0.02 & 0.10 & 0.03 & 0.20 & 0.07 \\
\hline 40 & 0.59 & 0.12 & 0.03 & 0.02 & 0.10 & 0.03 & 0.20 & 0.06 \\
\hline 45 & 0.69 & 0.14 & 0.07 & 0.01 & 0.10 & 0.03 & 0.20 & 0.06 \\
\hline 50 & 0.69 & 0.15 & 0.07 & 0.02 & 0.13 & 0.03 & 0.23 & 0.06 \\
\hline 55 & 0.79 & 0.15 & 0.10 & 0.02 & 0.13 & 0.03 & 0.26 & 0.06 \\
\hline & 1.00 & 1.00 & $<0.20$ & $<0.20$ & -- & -- & $<0.50$ & $<0.50$ \\
\hline & Met, $<60 \mathrm{deg}$ & Met & Met & Met & -- & -- & Met & Met \\
\hline
\end{tabular}

aPerformance standard check values are from U.S. Army Corps of Engineers (2004c), table 3-1.

pre-survey lake test values (albeit different because of striking the log). The Mississippi River patch test was re-examined using the offset values obtained from the November lake test, resulting in reasonable alignment of the patch test data without erroneous offset artifacts. Furthermore, the November lake test offsets were used to process the sites surveyed after striking the log, and resulted in much better appearance of the data at the affected sites, without artifacts typically caused by erroneous offsets. Recent analysis indicates there may be flexure of the pole on which the sonar head is deployed (fig. $3 B$ ) when fully extended, which may be affecting patch tests performed in a riverine environment, resulting in variable pitch values based on the speed of the boat and sonar head in the water (the pole flexes rearward more when the boat is traveling upstream against the current than when it is traveling downstream with the current, resulting in differing pitch values). Investigation and mitigation of this phenomenon currently is ongoing; nevertheless, the discussion below ignores the initial, erroneous offset values obtained for the Mississippi River patch test.

For this study, there was no measured timing offset (table $3 ; \Delta t=0$, fig. 4 ), which is consistent with latency test results for this boat and similar equipment configuration used in other surveys (Huizinga, 2010, 2011; Huizinga and others, 2010; Richard Huizinga, unpub. data, 2012). The measured angular offset for yaw equaled a constant value of 2.70 degrees (table 3 ), which is consistent with the angular offset for yaw value determined for this boat and sonar head during previous recent surveys (Richard Huizinga, unpub. data, 2012).

The measured angular offset for roll was -2.80 degrees from the first patch test, -2.50 degrees from the second patch test, and -1.80 degrees from the last patch test (table 3 ). The first two values are consistent with roll values determined for this boat and sonar head during previous recent surveys (Richard Huizinga, unpub. data, 2012). The change from the second to the last roll offset values is the result of striking a substantial submerged log, causing the mount to bend. No specific causal factor was identified for the changing value between the first and second patch tests, but may have been the result of multiple smaller collisions with debris. It was noted in Huizinga (2010) that a sensitivity analysis of the four offsets implied that the ultimate position of surveyed points in three-dimensional space was least sensitive to the angular offset for yaw, whereas it was most sensitive to the angular offset for roll.

The measured angular offset for pitch was 3.20 degrees for the first two patch tests, and 2.90 degrees for the last patch test (table 3). As with the angular offset for roll, these values are consistent with angular offset for pitch values determined for this boat and sonar head during previous recent surveys (Richard Huizinga, unpub. data, 2012), and the change from the second to the last pitch offset values is the result of striking the submerged log.

The bathymetric data were processed to apply the offsets determined from the patch tests and to remove data spikes and other spurious points in the multibeam swaths. The bathymetric data were then projected to a three-dimensional grid at a resolution of $0.66 \mathrm{ft}(0.2 \mathrm{~m})$. The bathymetric data were used to generate a gridded raster surface of the channel bed in the vicinity of each bridge using ArcGIS. 


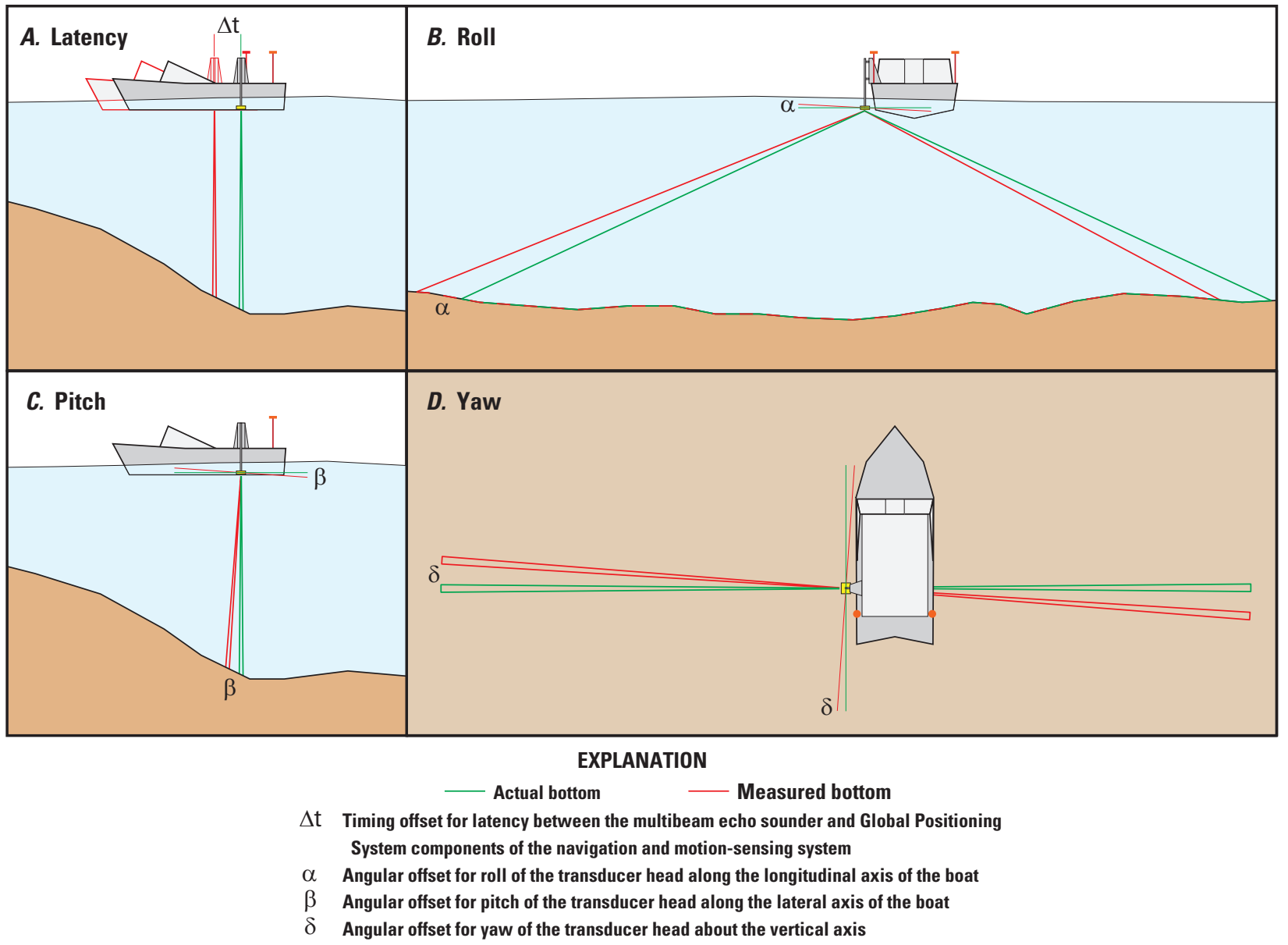

Figure 4. Effects of $A$, timing offset for latency, and angular offsets for $B$, roll, $C$, pitch, and $D$, yaw on data from a multibeam echo sounder.

Table 3. Results of patch tests performed at Longview Lake and Blue Springs Lake, Missouri, and on the Mississippi River at Alton, Illinois, before, during, and after surveying on the Missouri River in Missouri.

[sec, seconds; deg, degrees]

\begin{tabular}{lccccl}
\hline Date of test & $\begin{array}{c}\text { Timing offset } \\
\text { (sec) }\end{array}$ & $\begin{array}{c}\text { Angular offset } \\
\text { for roll } \\
\text { (deg) }\end{array}$ & $\begin{array}{c}\text { Angular offset } \\
\text { for pitch } \\
\text { (deg) }\end{array}$ & $\begin{array}{c}\text { Angular offset } \\
\text { for yaw } \\
\text { (deg) }\end{array}$ & Location \\
\hline $07 / 06 / 11$ & 0 & -2.80 & 3.20 & 2.70 & Longview Lake, Missouri \\
$07 / 20 / 11$ & 0 & -2.50 & 3.20 & 2.70 & Blue Springs Lake, Missouri \\
$08 / 06 / 11$ & $\mathrm{a}-0.10$ & $\mathrm{a}-1.80$ & 3.00 & ${ }^{\mathrm{a}} 0.60$ & Mississippi River at Alton, Illinois ${ }^{\mathrm{a}}$ \\
$08 / 06 / 11$ & 0 & -1.80 & 2.90 & 2.70 & Mississippi River at Alton, Illinois, reprocessed \\
$11 / 16 / 11$ & 0 & -1.80 & 2.90 & 2.70 & Blue Springs Lake, Missouri \\
\hline
\end{tabular}

${ }^{a}$ Results from initial river-based patch test disregarded in favor of subsequent lake-based patch test.

${ }^{b}$ Intial river-based patch test was reprocessed using subsequent lake-based patch test offsets, resulting in reasonable alignment of patch test data similar to that obtained with intial offsets and without artifacts typically caused by erroneous offsets. 
In parts of nearly all the surveys - and particularly in flat areas - there appeared to be artifacts in the data that might be caused by an incorrect angular offset for pitch or roll. These artifacts appear as longitudinal stripes at the interface between the survey swaths, where the outer beams would have been out of alignment with each other from one survey pass to the next with an incorrect angular offset for roll. These alignment differences also can be caused by actual differences in the bed from one survey pass to the next caused by bed movement with time, and given the substantial potential for sediment transport caused by the high-flow conditions during the surveys and that these longitudinal stripes appear in the surveys immediately before and after the second patch test (when the established offset values were most constant and there presumably would be less effect from an inaccurate offset value), it often was assumed that actual bed movement had occurred between the survey passes. However, as mentioned earlier in this section, recent findings indicate there may be flexure of the sonar mounting pole when fully extended, which may have resulted in variable pitch values based on the speed of the boat and sonar head in the water when traveling upstream as opposed to downstream. The elevation difference represented by the longitudinal stripes ranges from less than $0.1 \mathrm{ft}$ to approximately $0.5 \mathrm{ft}$, which is within the uncertainty of the surveys, as described in the next section.

\section{Uncertainty Estimation}

To estimate the uncertainty in the surveys, the Combined Uncertainty Bathymetric Estimator (CUBE) method (Calder and Mayer, 2003), as implemented in the HYPACK ${ }^{\circledR /}$ HYSWEEP $^{\circledR}$ software (HYPACK, Inc., 2011), was used to estimate total propagated uncertainty (TPU) for the gridded surface of each survey area. The CUBE method allows all random system component uncertainties and resolution effects to be combined and propagated through the data processing steps, which provides a robust estimate of the spatial distribution of possible uncertainty within the survey area (Czuba and others, 2011). Thus, the TPU of a point is a measure of the accuracy to be expected for such a point, when all relevant error sources are taken into account (Czuba and others, 2011). Statistics of TPU for each of the survey areas are shown in table 4, and examples of the spatial distribution of TPU typically observed in the survey data are shown in figures 5 and 6 for the bathymetric data at structure 59-3-16.38(013) on U.S. Highway 59 at Atchison, Kansas, and at structures 435-10511.97 (235) and 435-105-11.98 (240) on Interstate 435 near Kansas City, Missouri.

The largest TPU in the Missouri River surveys was about $6.43 \mathrm{ft}$ (table 4); however, TPU values of this magnitude typically occurred near high-relief features, such as the front or side of a pier footing or large submerged object (figs. 5, 6). Most of the TPU values (more than 98 percent) were less than $1.64 \mathrm{ft}(0.5 \mathrm{~m}$; table 4$)$, with larger values occurring near moderate-relief features (banks, dune faces, rock riprap, spur dikes, and scour holes; figs. 5, 6). Occasionally, these larger
TPU values also occurred in the outermost beam parts of the multibeam swath in the overlap with an adjacent swath, typically in the channel thalweg, which is the line of maximum depth in the channel, where substantial bed movement would occur between survey passes or where variable pitch of the sonar caused by pole flexure on adjacent upstream and downstream passes might have occurred (figs. 5, 6). More than one-half (58 percent or more) of the channel bed at all of the surveyed sites except structure 59-3-16.38 (013) at Atchison, Kansas, had TPU values of $0.5 \mathrm{ft}$ or less, and more than 40 percent of the data at two-thirds of the sites have a total propagated uncertainty of less than 0.33 feet (table 4 ). The tops of bridge substructural elements (pier footings and seal courses) typically had TPU values of $0.2 \mathrm{ft}$ or less.

The survey at structure 59-3-16.38 (013) on U.S. Highway 59 at Atchison, Kansas, had the highest mean value of TPU, and the lowest percentage of bathymetry points that were less than the various TPU value cutoffs (table 4). At this site, the highway bridge is in proximity to the railroad bridge, and the water-surface elevation was high enough to prevent clearance under the railroad bridge, preventing acquisition of data upstream from the railroad bridge (fig. 5). Between the railroad bridge and the highway bridge, smooth navigation of the boat was hampered by flow around piers, and abrupt turns had to be made immediately downstream from the railroad bridge during the survey; furthermore, GPS multipath errors likely were at a maximum with the steel superstructure of both bridges blocking or redirecting GPS signal. Therefore, TPU values were greatest in the vicinity of the railroad and highway main channel piers (fig. 5).

The next-highest mean values of TPU were observed at structures 435-105-11.97 (235) and 435-105-11.98 (240) on Interstate 435 near Kansas City, Missouri (table 4; fig. 6). Unlike at structure 59-3-16.38 (013) at Atchison, Kansas, there were no impediments to flow or surveying at this site, and the survey was obtained with smooth longitudinal swathes, which was the case at nearly all of the other sites surveyed as part of this study. Therefore, the magnitude and distribution of TPU values observed at this site are more representative of those observed at all of the other surveyed sites except structure 59-3-16.38 (013) on U.S. Highway 59 at Atchison, Kansas.

\section{Results of Bathymetric Surveys}

The site-specific results for each bridge are discussed in the following sections starting with the upstream-most bridge site and progressing downstream, followed by a discussion of general findings that are not specific to a particular site. The range of bed elevations described as "the channel-bed elevations" for each survey were based on statistical analysis of the bathymetry data at each site, and covers the percentile range from 5 to 95 percent of the data. Because the survey was limited to the active channel and generally excluded overbank areas, this percentile range generally covered the channel bed 
Table 4. Total propagated uncertainty results for bathymetric data at a 1-meter grid spacing from surveys on the Missouri River in Missouri, from July 13 to August 3, 2011.

[MoDOT, Missouri Department of Transportation; KDOT, Kansas Department of Transportation; TPU, total propagated uncertainty; ft, feet; E, eastbound; W, westbound]

\begin{tabular}{|c|c|c|c|c|c|c|c|c|}
\hline \multirow{2}{*}{$\begin{array}{c}\text { Site } \\
\text { number } \\
\text { (fig. 1) }\end{array}$} & \multirow{2}{*}{$\begin{array}{l}\text { MoDOT or KDOT } \\
\text { structure number }\end{array}$} & \multirow{2}{*}{$\begin{array}{c}\text { Maximum } \\
\text { value of } \\
\text { TPU } \\
\text { (ft) }\end{array}$} & \multirow{2}{*}{$\begin{array}{l}\text { Mean } \\
\text { value of } \\
\text { TPU } \\
\text { (ft) }\end{array}$} & \multirow{2}{*}{$\begin{array}{c}\text { Standard } \\
\text { deviation } \\
\text { of TPU } \\
\text { (ft) }\end{array}$} & \multicolumn{4}{|c|}{$\begin{array}{c}\text { Percent of bathymetry points with TPU } \\
\text { value less than }\end{array}$} \\
\hline & & & & & $1.64 \mathrm{ft}$ & $0.82 \mathrm{ft}$ & $0.50 \mathrm{ft}$ & $0.33 \mathrm{ft}$ \\
\hline \multicolumn{9}{|c|}{ Upstream from Kansas City } \\
\hline 1 & L0098 & 3.97 & 0.43 & 0.27 & 99.7 & 90.4 & 71.0 & 41.4 \\
\hline 2 & A3664 E \& W & 3.22 & 0.54 & 0.37 & 98.3 & 80.6 & 58.3 & 32.2 \\
\hline 3 & $59-3-16.38(013)$ & 4.23 & 0.63 & 0.35 & 98.4 & 74.8 & 41.9 & 15.8 \\
\hline 4 & $92-52-18.48(026)$ & 3.61 & 0.51 & 0.33 & 98.9 & 83.7 & 60.5 & 33.1 \\
\hline \multicolumn{9}{|c|}{ Greater Kansas City area } \\
\hline 5 & $\begin{array}{l}435-105-11.97(235) \\
435-105-11.98(240)\end{array}$ & 5.71 & 0.54 & 0.36 & 98.6 & 81.4 & 59.5 & 29.6 \\
\hline 6 & A 1800 & 5.15 & 0.47 & 0.33 & 98.9 & 86.6 & 66.8 & 37.6 \\
\hline 7 & K0456/A0450 & 5.54 & 0.45 & 0.35 & 99.1 & 85.1 & 66.8 & 46.3 \\
\hline 8 & A4649 & 5.84 & 0.41 & 0.33 & 99.0 & 88.9 & 72.6 & 51.9 \\
\hline 9 & A4060 & 5.41 & 0.44 & 0.35 & 98.9 & 86.6 & 68.7 & 45.9 \\
\hline 10 & A7650 & 5.48 & 0.46 & 0.31 & 99.2 & 87.9 & 66.5 & 38.6 \\
\hline 11 & A5817 & 5.28 & 0.41 & 0.30 & 99.3 & 90.2 & 74.0 & 49.6 \\
\hline 12 & A0767 & 5.91 & 0.46 & 0.31 & 99.3 & 87.1 & 65.7 & 39.4 \\
\hline 13 & A4757/L0568 & 4.59 & 0.51 & 0.37 & 98.2 & 83.3 & 62.6 & 34.8 \\
\hline \multicolumn{9}{|c|}{ Between Kansas City and St. Louis } \\
\hline 14 & A5664 & 4.04 & 0.47 & 0.35 & 98.4 & 86.6 & 69.3 & 40.5 \\
\hline 15 & A5910 & 6.10 & 0.38 & 0.28 & 99.5 & 92.1 & 76.7 & 50.6 \\
\hline 16 & K0999 & 6.43 & 0.40 & 0.27 & 99.4 & 92.4 & 77.2 & 47.3 \\
\hline 17 & G0069 & 3.54 & 0.41 & 0.29 & 99.4 & 91.0 & 74.8 & 46.9 \\
\hline 18 & A4574 & 4.04 & 0.36 & 0.25 & 99.7 & 93.7 & 80.7 & 54.5 \\
\hline 19 & L0962 & 4.72 & 0.43 & 0.32 & 99.0 & 88.9 & 72.4 & 44.4 \\
\hline 20 & L0550/A4497 & 4.56 & 0.48 & 0.34 & 98.5 & 86.9 & 67.3 & 37.9 \\
\hline 21 & A6288 & 4.76 & 0.38 & 0.27 & 99.5 & 92.9 & 79.0 & 52.1 \\
\hline 22 & K0969 & 4.07 & 0.39 & 0.28 & 99.5 & 91.8 & 77.5 & 51.6 \\
\hline \multicolumn{9}{|c|}{ Greater St. Louis area } \\
\hline 23 & A4017/J1000 & 5.48 & 0.38 & 0.27 & 99.5 & 92.7 & 78.8 & 52.8 \\
\hline 24 & A5585 E \& W & 4.63 & 0.36 & 0.25 & 99.7 & 94.0 & 81.2 & 55.0 \\
\hline 25 & A3292/L0561 & 5.28 & 0.41 & 0.28 & 99.5 & 91.4 & 74.2 & 46.3 \\
\hline 26 & A4557 E \& W & 3.87 & 0.37 & 0.25 & 99.7 & 93.9 & 79.6 & 52.5 \\
\hline 27 & A3047 & 4.56 & 0.38 & 0.27 & 99.5 & 93.0 & 78.0 & 50.2 \\
\hline
\end{tabular}

but excluded the banks and localized high or low spots, such as spur dikes or scour holes near piers. All elevation data were referenced to the North American Vertical Datum of 1988 (NAVD 88).

The discharge value reported for each site was determined from the streamgage at or upstream from the site in question, for a variety of reasons. Typically, there are tributary inflows between gaging stations, but gaging stations are located such that major inflows generally are counted. Furthermore, as mentioned in the "Description of Missouri River Flood of 2011 in Missouri" section above, there essentially was no flow from the tributary basins during the 

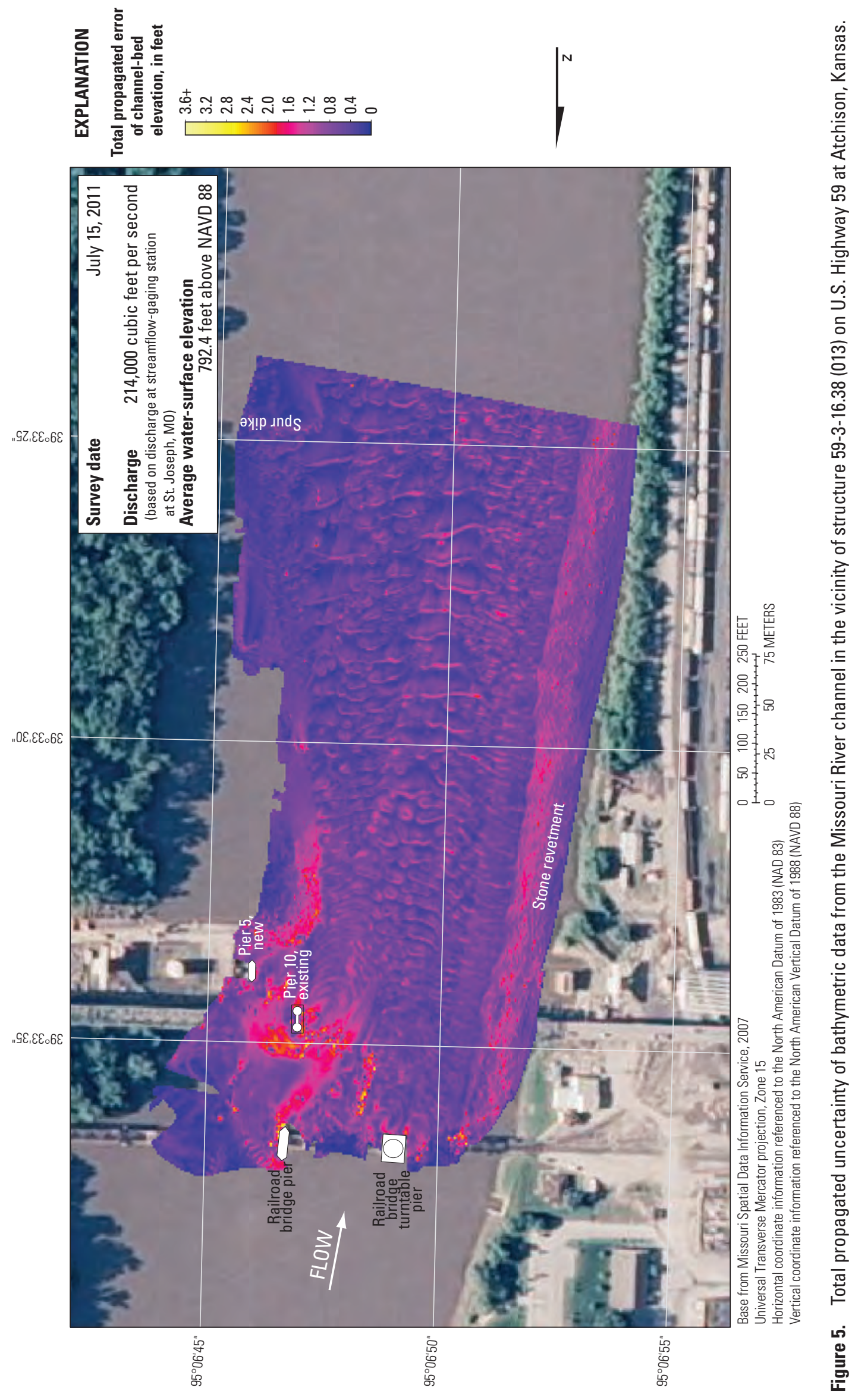

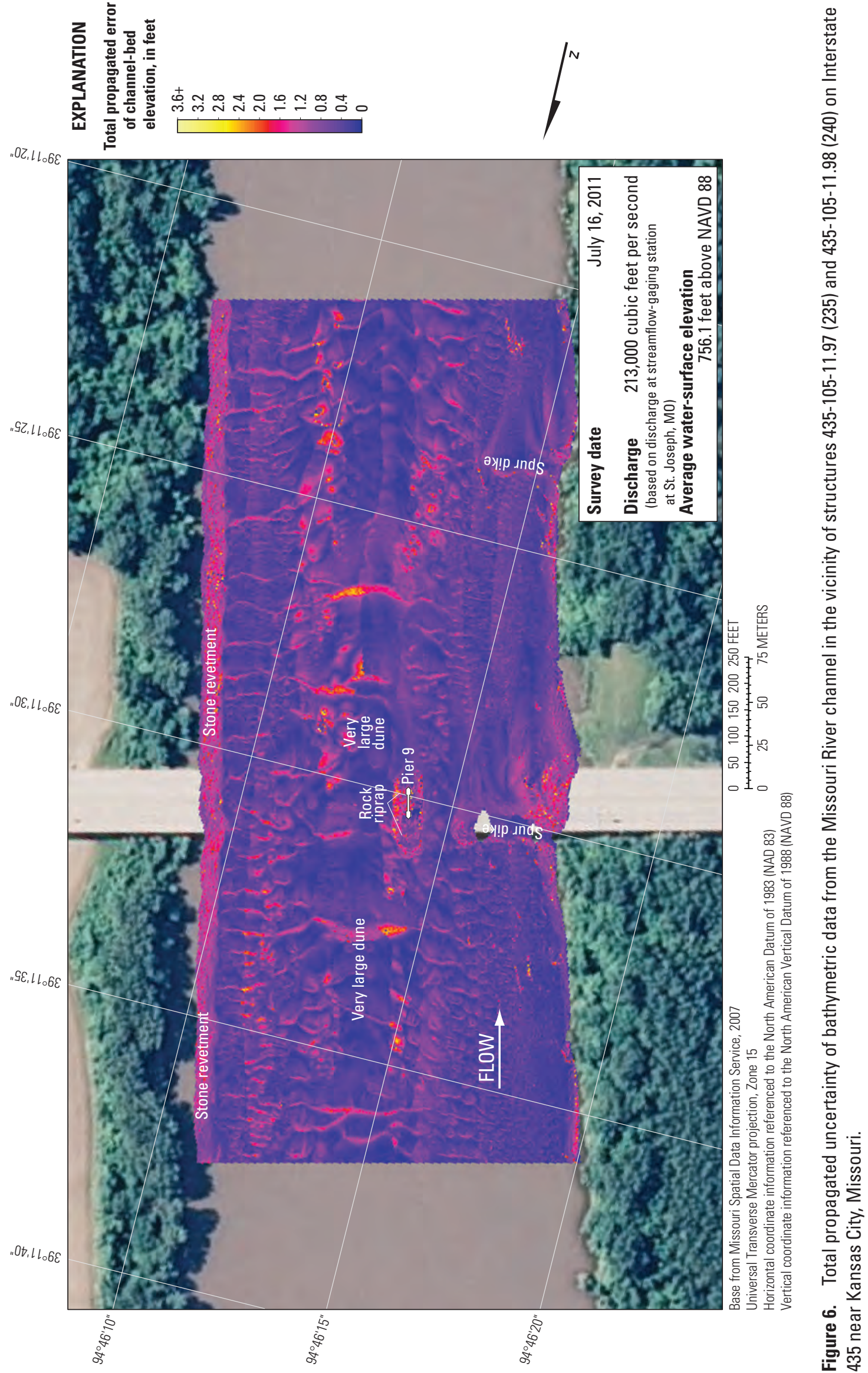
peak of the flooding in 2011, resulting in almost constant values of discharge between streamgages as the flood wave passed downstream (fig. $2 A$ ). Finally, discharge values from a streamgage generally have been checked for quality and consistency with respect to other measurements and the longterm stage and discharge record at that streamgage. Although most of the established protocols (Mueller and Wagner, 2009) were followed when obtaining data for the velocity transects with the ADCP, velocity — not discharge — was the primary variable of interest. Therefore, some of these ADCP discharge measurements were lower than the value of discharge from the streamgage at or upstream from the site because they did not include edge estimates of discharge or measurements in the overbank areas - which was substantial at some locations, particularly the sites farthest upstream. Ultimately, several of the ADCP discharge values were larger (as much as 8.8 percent larger) than the rated, approved, and quality-checked value of discharge from the streamgage at or upstream from the site, although no explanation for this difference was determined.

Dune sizes are described in general terms for each of the bridge sites. In this report, small dunes and ripples are those that are less than $5 \mathrm{ft}$ high from crest to trough, medium dunes are those that are 5 to $10 \mathrm{ft}$ high, large dunes are those that are 10 to $15 \mathrm{ft}$ high, and very large dunes are those that are $15 \mathrm{ft}$ or more in height. The reader is advised that these ranges are different than those used by Richardson and Davis (2001; wherein a "small" dune is 2 to $10 \mathrm{ft}$ high, "medium" is 10 to $30 \mathrm{ft}$ high, and "large" is greater than $30 \mathrm{ft}$ high), but are used herein to provide more descriptive definition of the dune sizes.
Several of the bridge sites have been the subject of previous bathymetric surveys or have had a Level II bridge scour assessment (Lagasse and others, 1991). For those bridges at which a bathymetric survey has been completed in the past, a map showing the change in channel-bed elevation is included, and any previous scan is included in the cross-section plot for that bridge. If a Level II assessment has been performed at the site, the cross section of the channel on the downstream side of the bridge obtained during the Level II assessment is included on the cross-section plot for that bridge.

When discussing the vertically averaged velocity values obtained during the surveys in the sections that follow, neighboring vectors with random variations in direction and magnitude were taken as an indication of turbulence in the transect. On the other hand, neighboring vectors with gradual and systematic variations were taken as an indication of uniform flow in the transect.

The sites are grouped into four general regions: those upstream from Kansas City, along the reach of the Missouri that borders Nebraska and Kansas; those in the greater Kansas City area; those between Kansas City and St. Louis, along the reach of the Missouri River in Missouri; and those in the greater St. Louis area. Those sites in the greater Kansas City and St. Louis areas generally have had previous bathymetric surveys, documented by Huizinga (2010, 2011). Those sites north of Kansas City and between Kansas City and St. Louis generally have not had previous bathymetric surveys. 


\section{Upstream from Kansas City}

There are five unique highway crossings of the Missouri River upstream from Kansas City (table 1; fig. 1). Four of the crossings were surveyed during the summer 2011 flooding as part of this study.

\section{Structure L0098 on U.S. Highway 136 at Brownville, Nebraska}

Structure L0098 (site 1) on U.S. Highway 136 crosses the Missouri River at river mile (RM) 535.3 at Brownville, Nebraska, in the northwestern corner of Missouri (fig. 1). The site was surveyed on July 13, 2011; the average water-surface elevation of the river in the survey area, determined by the RTK GPS tide solution, was $898.9 \mathrm{ft}$ (table 5). Flow on the Missouri River was about 225,000 ft $/ \mathrm{s}$ during the survey, according to the streamgage at Brownville, Nebraska (table 5).

The survey area was about 1,640 ft long and about $740 \mathrm{ft}$ wide, extending across the active channel from bank to bank (fig. 7). The upstream end of the survey area was about $740 \mathrm{ft}$ upstream from the centerline of structure L0098 (fig. 7). The channel-bed elevations ranged from about 857 to $874 \mathrm{ft}$ for most of the surveyed area ( 5 to 95 percentile range of the bathymetric data), except near pier 3 and on the downstream sides of the various spur dikes on the left (east) bank (fig. 7). The overall minimum channel-bed elevation of $845.7 \mathrm{ft}$ was in a hole downstream from the upstream spur dike (fig. 7). A localized deep trough on the right (west) bank on the downstream end of the surveyed area had a minimum channel-bed elevation of $853 \mathrm{ft}$ (fig. 7). The channel bed was covered with medium and small dunes and ripples (fig. 7). A rock outcrop was present on the right (west) bank upstream from the bridge, and stone revetment was present on the right bank downstream from the bridge (fig. 7).

In the vicinity of main channel pier 3, a local scour hole had a minimum channel-bed elevation of approximately $846.0 \mathrm{ft}$ (table 6), about $17 \mathrm{ft}$ below the average channel bed immediately upstream from the pier (fig. 7). Information from bridge plans indicates that pier 3 is founded on sheet piling caissons on bedrock, with about $31 \mathrm{ft}$ of bed material between the bottom of the scour hole and bedrock at the upstream face of the pier (fig. 8; table 6). The unique configuration of the sheet pile caissons and ice breaker of the pier are clearly seen in a point cloud visualization of the multibeam depth points obtained during the survey (fig. 9).

A Level II scour assessment was performed at this site in November 2002 (Huizinga and Rydlund, 2004), and the surveyed channel bed from the multibeam scan was 5 to $10 \mathrm{ft}$ lower than the channel bed from the Level II scour survey for part of the channel to the left of pier 3, and similar to the channel bed from the Level II scour survey for part of the channel to the right of pier 3 (fig. 8); however, the channel bed from the multibeam scan was substantially lower than the Level II scour survey at both banks, and generally was 5 or more feet lower than the approximate ground line from bridge plans when the bridge was built in 1938, except for part to the right of the main channel pier (fig. 8).

The vertically averaged velocity vectors indicated mostly uniform flow at between 5 and 8 feet per second ( $\mathrm{ft} / \mathrm{s})$ in the main channel, except downstream from the spur dikes (fig. 10). The turbulence downstream from main channel pier 3 was not pronounced, and appeared to be no greater than the general turbulence observed in the channel. The slightly shallower channel near the bridge resulted in slightly higher velocities compared with the deeper, slower flows observed near the upstream end of the reach and in the localized deep trough at the downstream end of the reach.

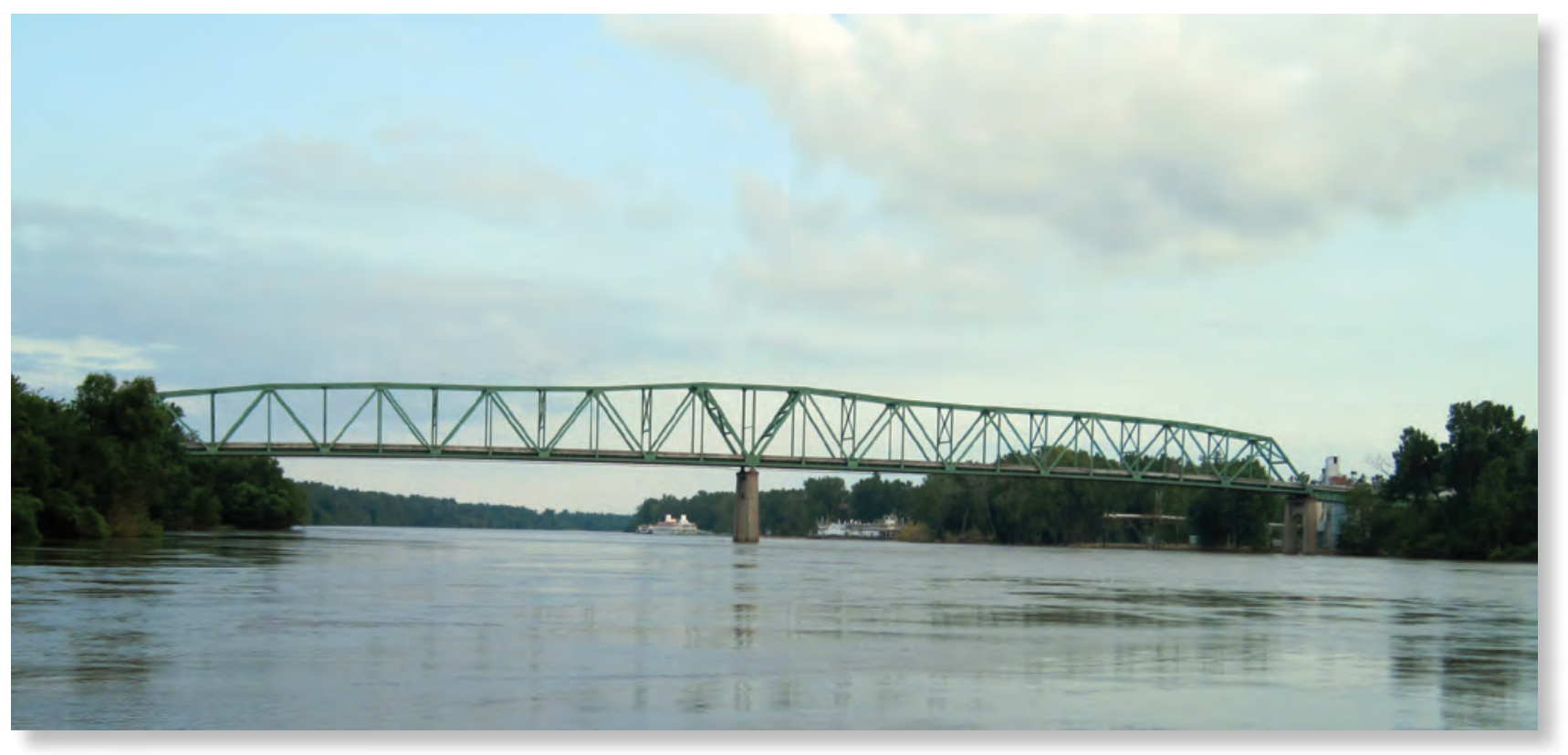

Structure L0098 on U.S. Highway 136 at Brownville, Nebraska. 


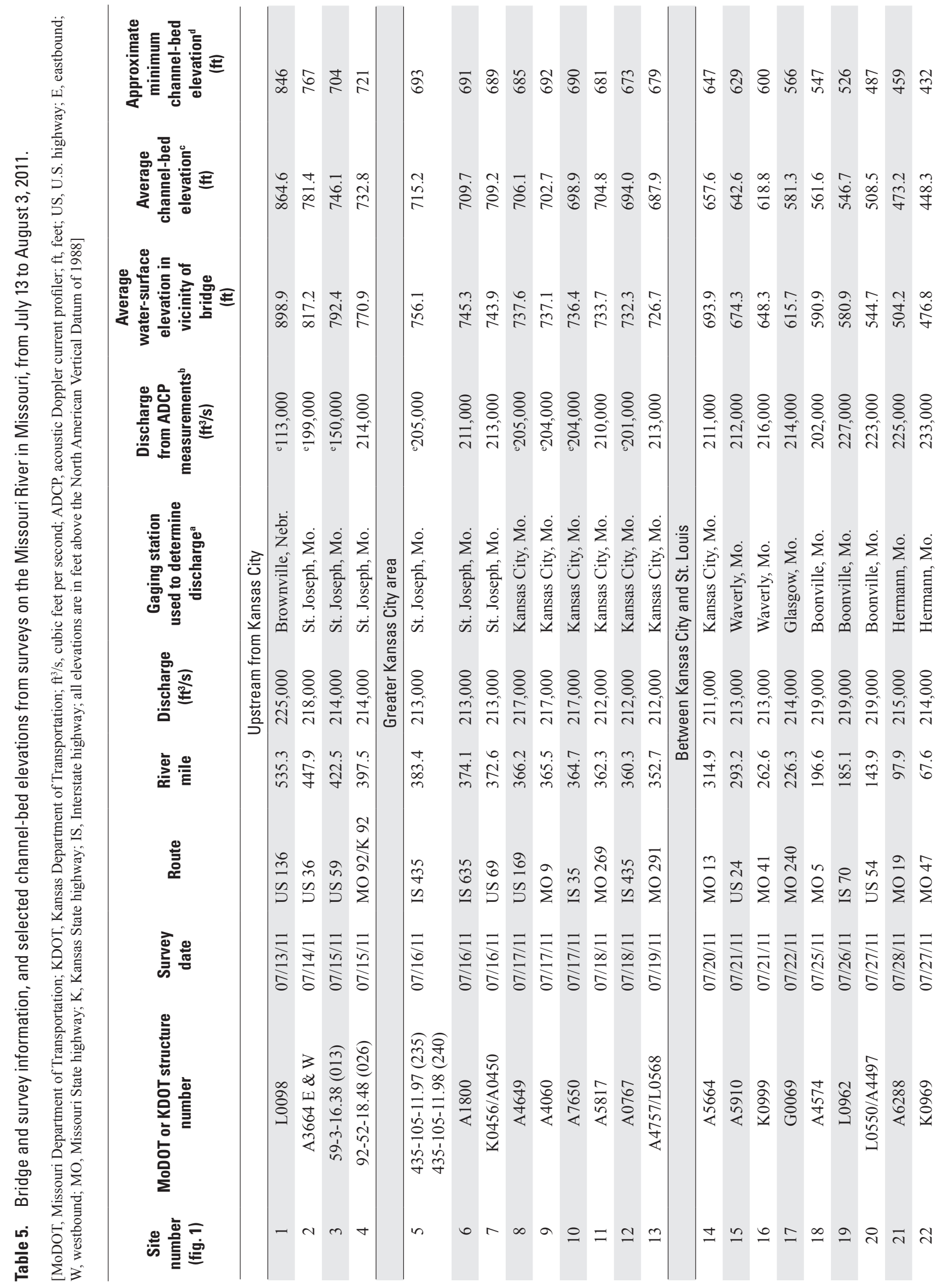




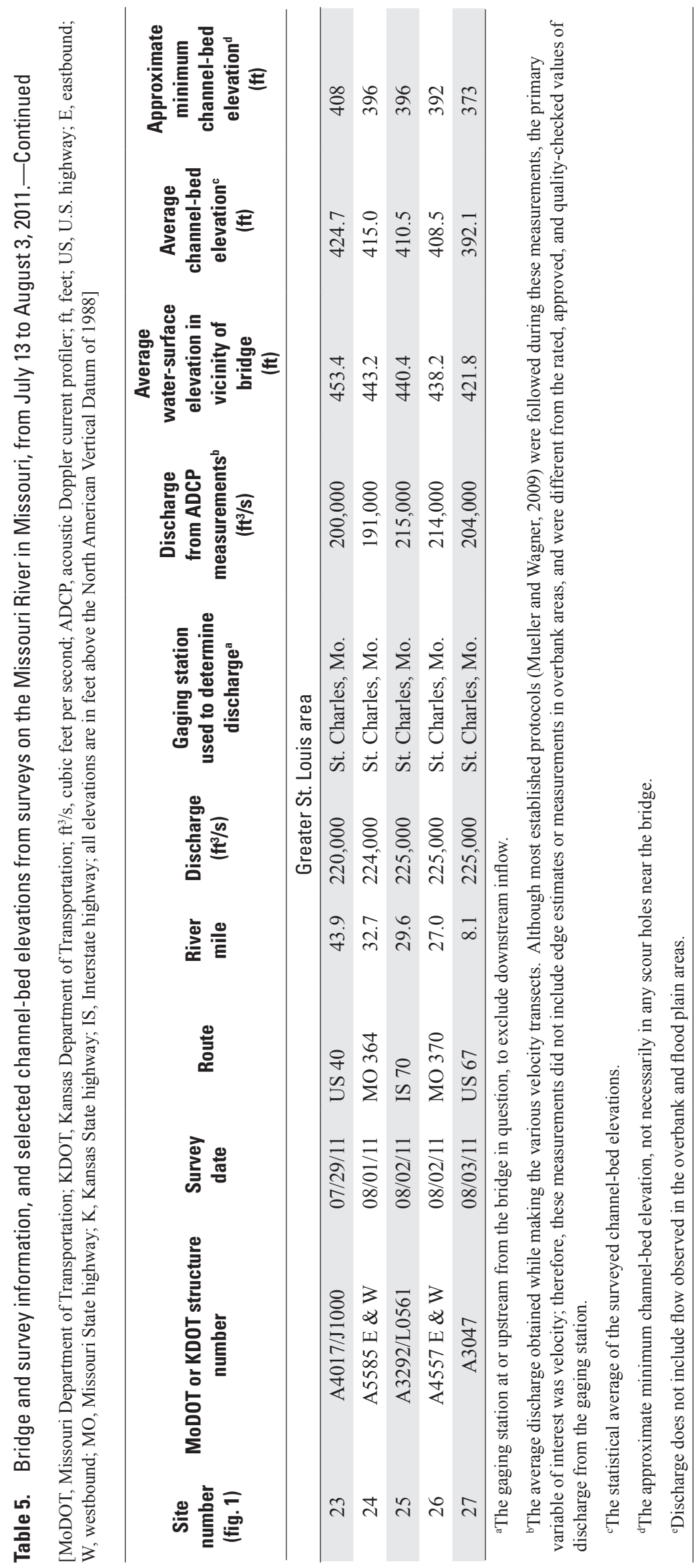




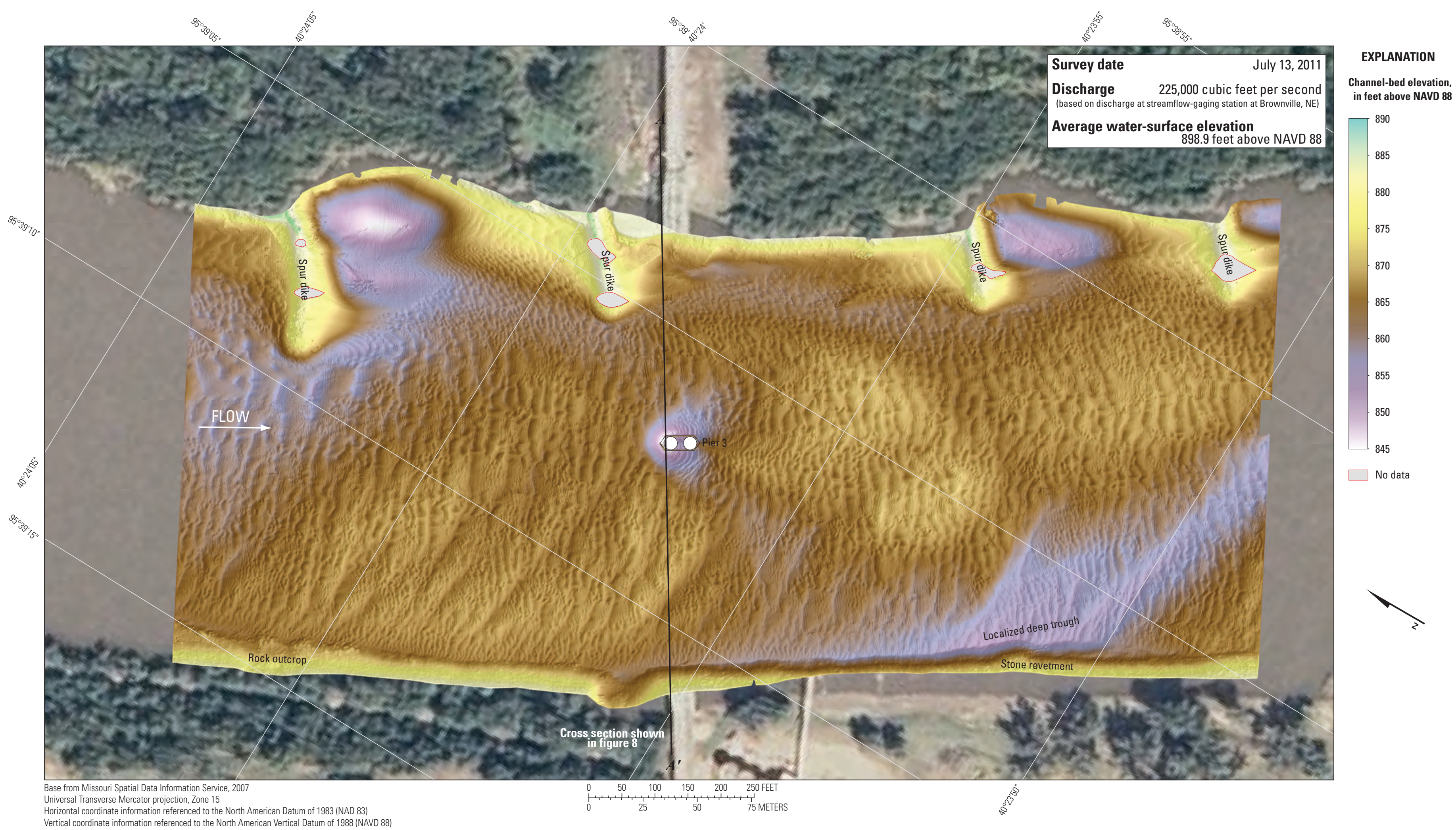

Figure 7. Bathymetric survey of the Missouri River channel in the vicinity of structure L0098 on U.S. Highway 136 at Brownville, Nebraska. 


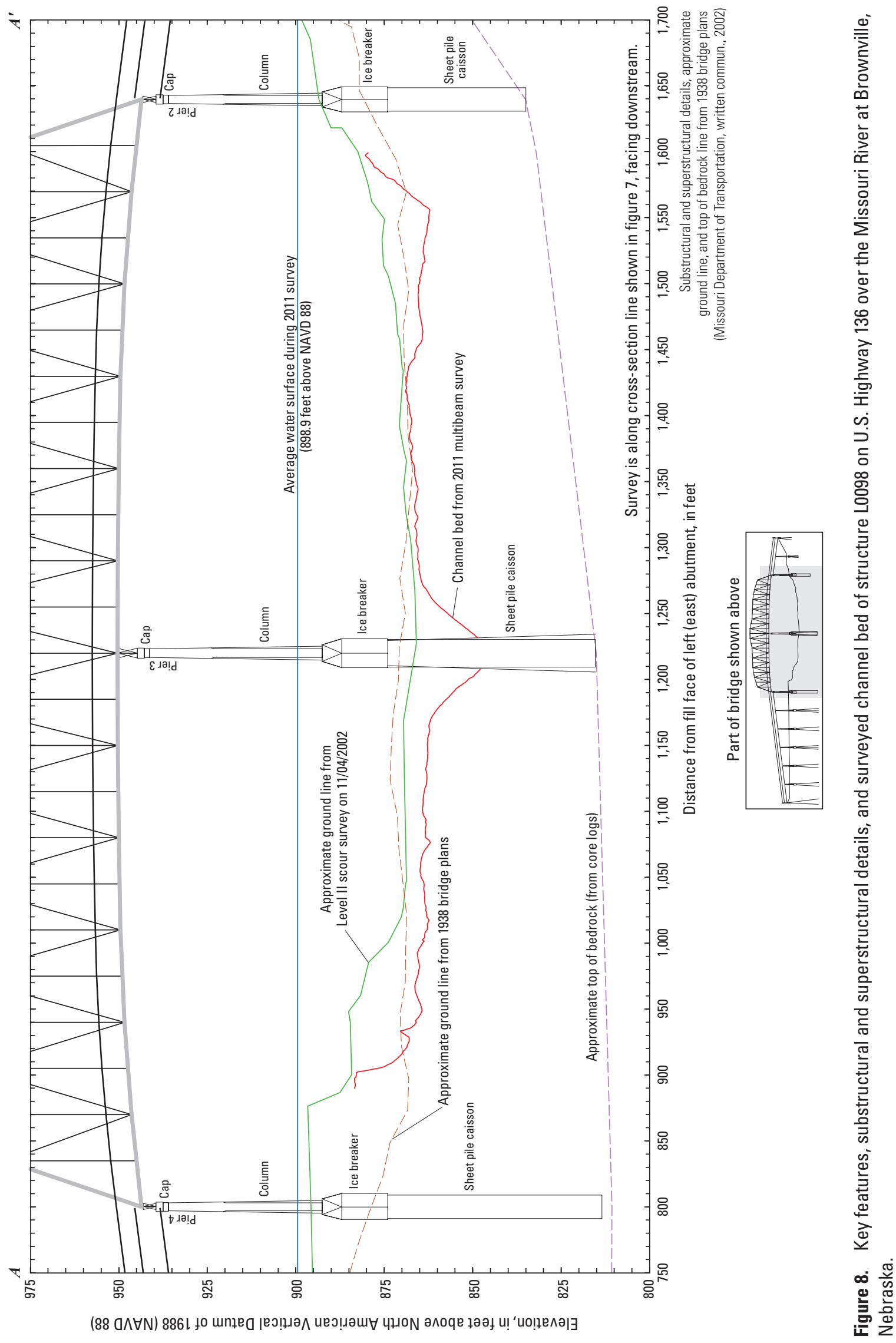




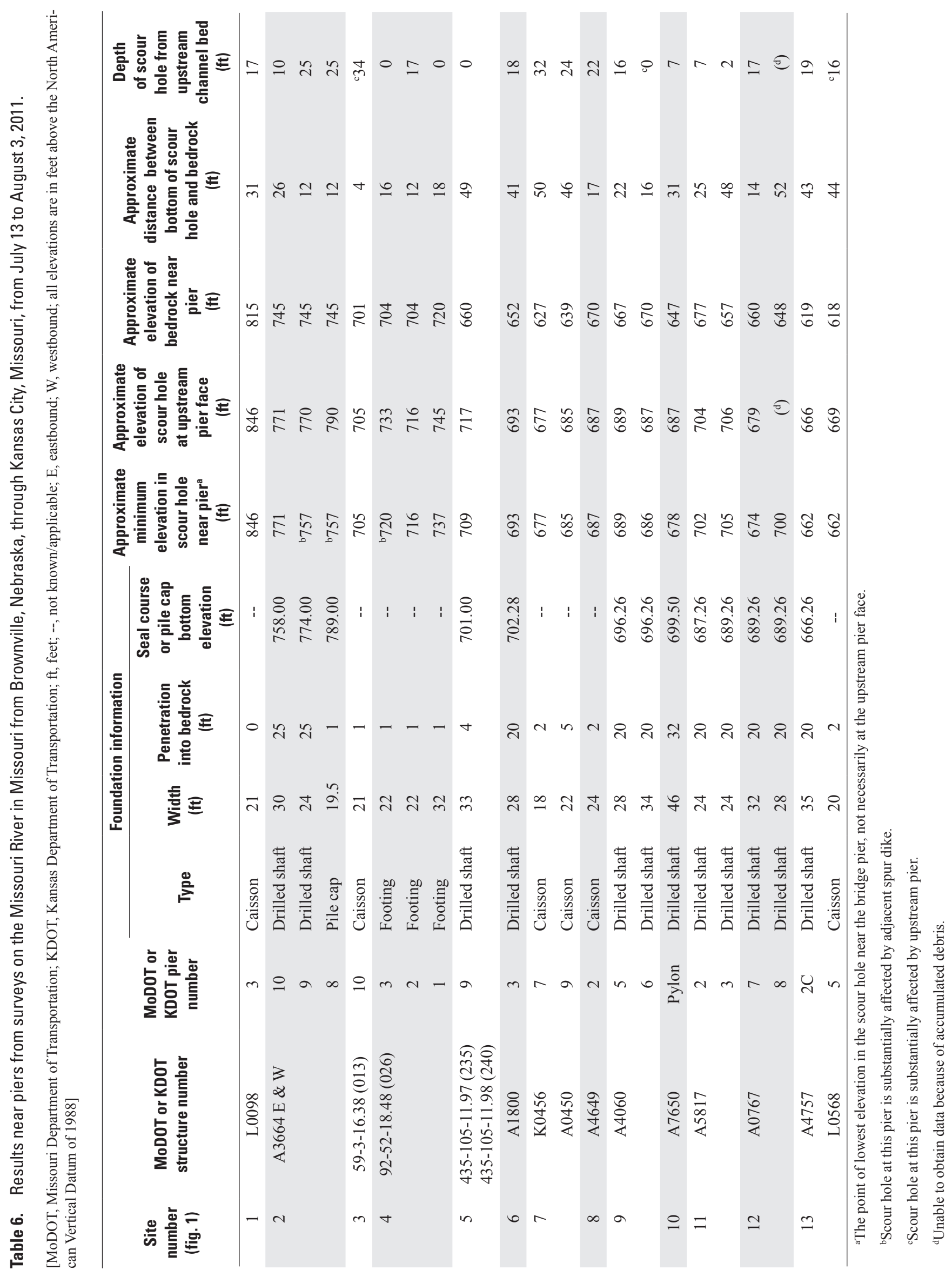




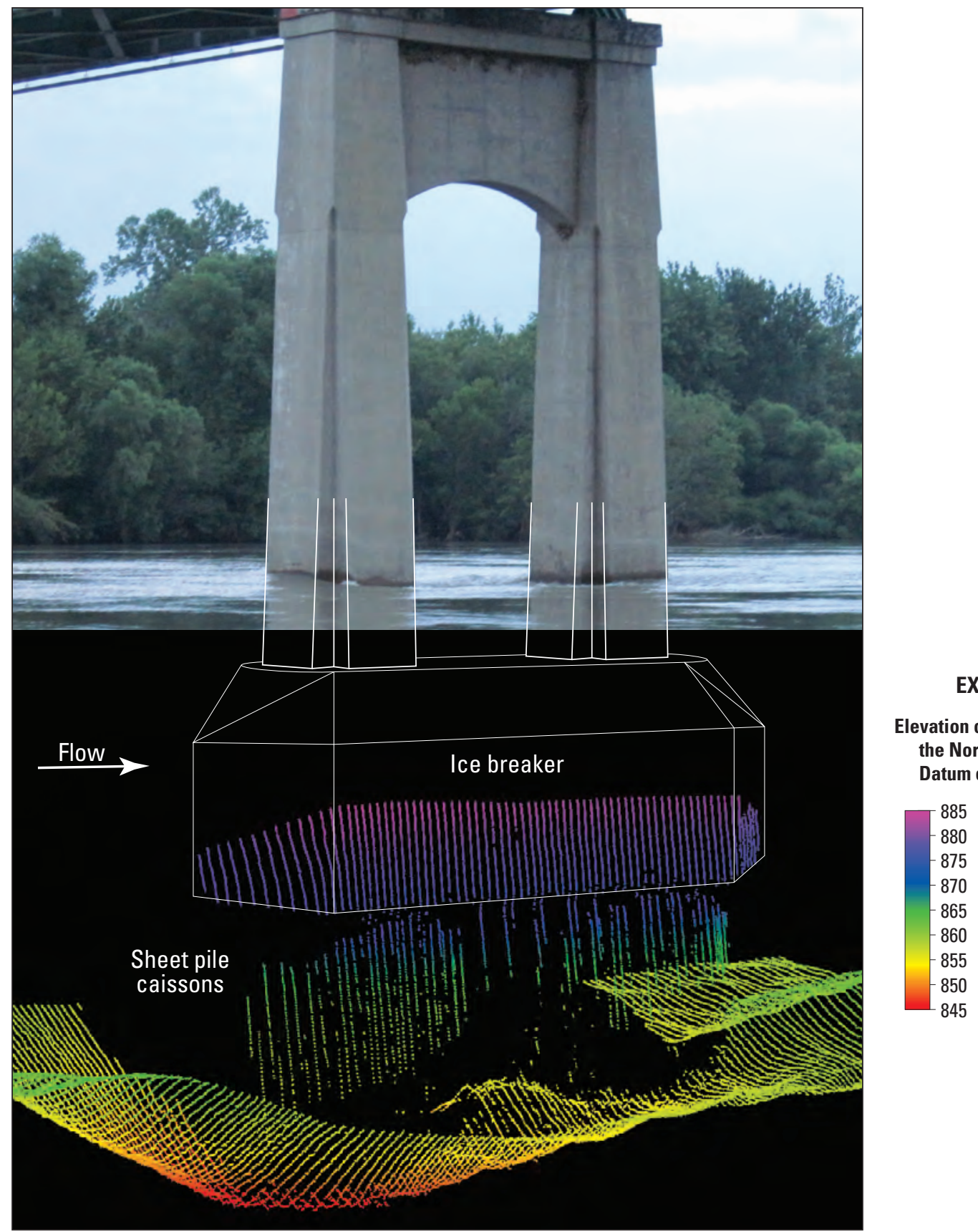

EXPLANATION

levation of point, in feet above the North American Vertical atum of 1988
$(855$
870
865
60
845

Figure 9. Point cloud visualization of the channel bed and right (west) side of pier 3 of structure L0098 on U.S. Highway 136 over the Missouri River at Brownville, Nebraska. 


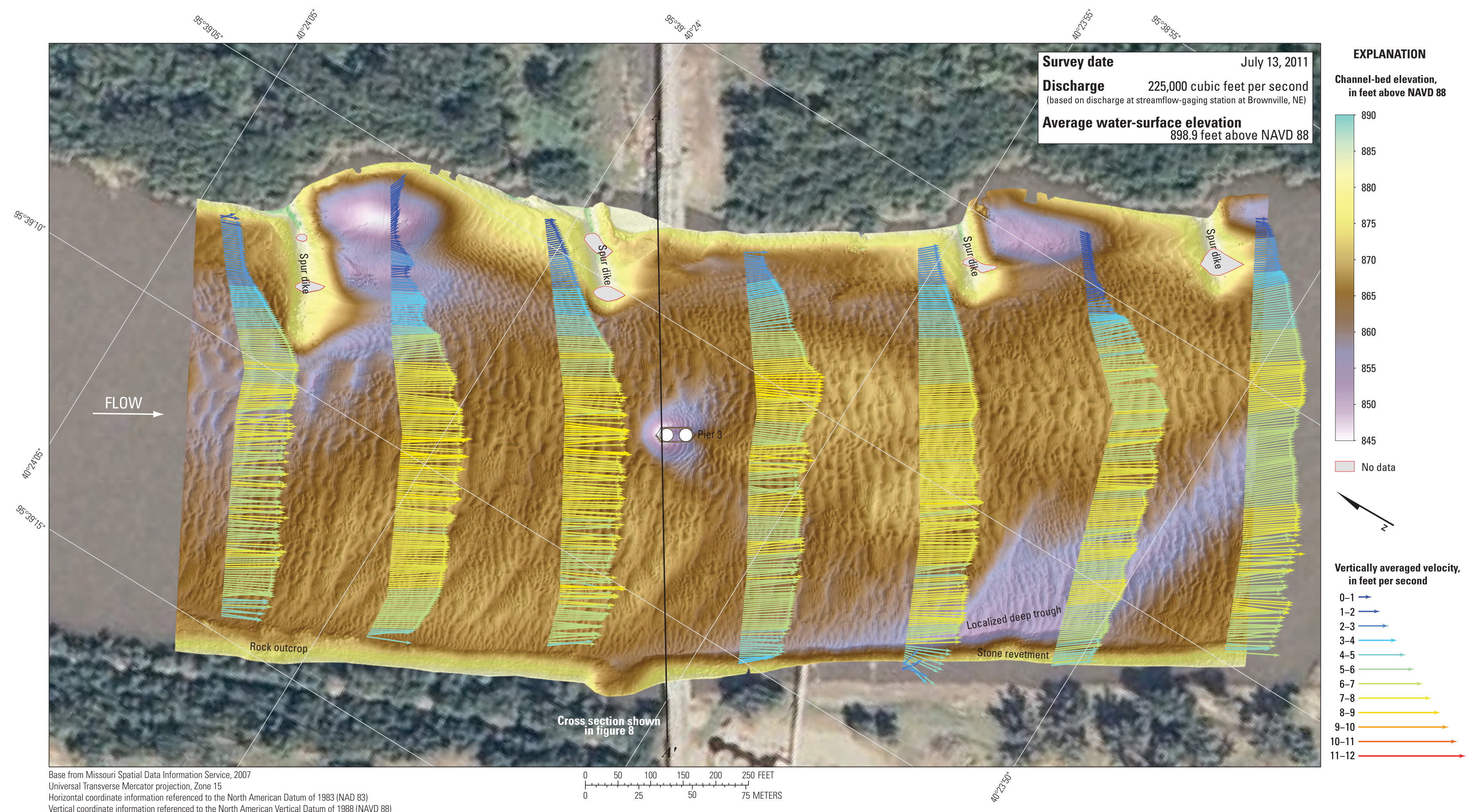

Figure 10. Bathymetry and vertically averaged velocities of the Missouri River channel in the vicinity of structure L0098 on U.S. Highway 136 at Brownville, Nebraska. 


\section{Dual Bridge Structure A3664 on U.S. Highway 36 at St. Joseph, Missouri}

Structure A3664 (site 2) consists of twin bridges on U.S. Highway 36 crossing the Missouri River at RM 447.9 at St. Joseph, Missouri, on the western side of Missouri north of Kansas City (fig. 1). The site was surveyed on July 14, 2011; the average water-surface elevation of the river in the survey area, determined by the RTK GPS tide solution, was $817.2 \mathrm{ft}$ (table 5). Flow on the Missouri River was about 218,000 $\mathrm{ft}^{3} / \mathrm{s}$ during the survey, according to the streamgage at St. Joseph, Missouri (table 5).

The survey area was about 1,640 ft long and about $870 \mathrm{ft}$ wide, extending across the active channel from bank to bank (fig. 11). The upstream end of the survey area was about $655 \mathrm{ft}$ upstream from the centerline of structure A3664 (fig 11). The channel-bed elevations ranged from about 773 to $791 \mathrm{ft}$ for most of the surveyed area ( 5 to 95 percentile range of the bathymetric data), except on the downstream sides of the two spur dikes on the right (west) bank, and near a mooring pylon at the upstream left (east) corner of the reach (fig. 11). The overall minimum channel-bed elevation of $756.5 \mathrm{ft}$ was in a hole downstream from the upstream spur dike on the right (west) bank, and the minimum channel-bed elevation near the mooring pylon at the upstream left (east) corner of the reach was $767.1 \mathrm{ft}$ (fig. 11). The center of the channel had numerous large dunes, and the remainder of the channel bed was covered with medium and small dunes and ripples (fig. 11). Stone revetment was present on the left (east) bank throughout the reach, and on the right (west) bank between the spur dikes and near the bridge and boat ramp (fig. 11).

In the vicinity of main channel pier 10, a local scour hole had a minimum channel-bed elevation of approximately $771 \mathrm{ft}$ (table 6), about $10 \mathrm{ft}$ below the average channel bed immediately upstream from the pier; however, this scour hole was difficult to differentiate from the large dunes in the middle of the channel (fig. 11). The large local scour hole downstream from the upstream spur dike resulted in a channel-bed elevation of $770.1 \mathrm{ft}$ at the upstream right corner of main channel pier 9 and a steeply sloping channel bed on the upstream left side of pier 8 on the right bank (figs. 11, 12). Information from bridge plans indicates that piers 9 and 10 are founded on shafts drilled into bedrock, with about $26 \mathrm{ft}$ of bed material between the bottom of the scour hole and bedrock at the upstream face of pier 10 (fig. 12; table 6); however, the local scour hole caused by the upstream spur dike results in substantially less material between the bottom of the scour hole and bedrock, and contributes to the scour observed at piers 8 and 9 (fig. 12; table 6). The stone revetment present on the right bank may provide some resistance to scour at pier 8 .

The surveyed bed generally was lower than the original ground line from bridge plans at the time of construction (1974) at dual bridge structure A3664, ranging from slightly higher than to as much as $30 \mathrm{ft}$ lower than the original ground line (fig. 12). For most of the channel cross section shown in figure 12, the surveyed bed was approximately $20 \mathrm{ft}$ lower than the original ground line from bridge plans at construction (1974).

The vertically averaged velocity vectors indicated mostly uniform flow at between 6 and $8 \mathrm{ft} / \mathrm{s}$ in the main channel, except downstream from the spur dikes (fig. 13) and a few localized areas of higher velocity near the upstream mooring pylon and in the downstream part of the reach. The turbulence downstream from main channel pier 10 was not pronounced, and appeared to be no greater than the general turbulence observed in the channel. The turbulence downstream from piers 8 and 9 may be a function of the turbulence caused by the upstream spur dike (fig. 13). The downstream spur dike did not cause as much turbulence as the upstream spur dike (fig 13).

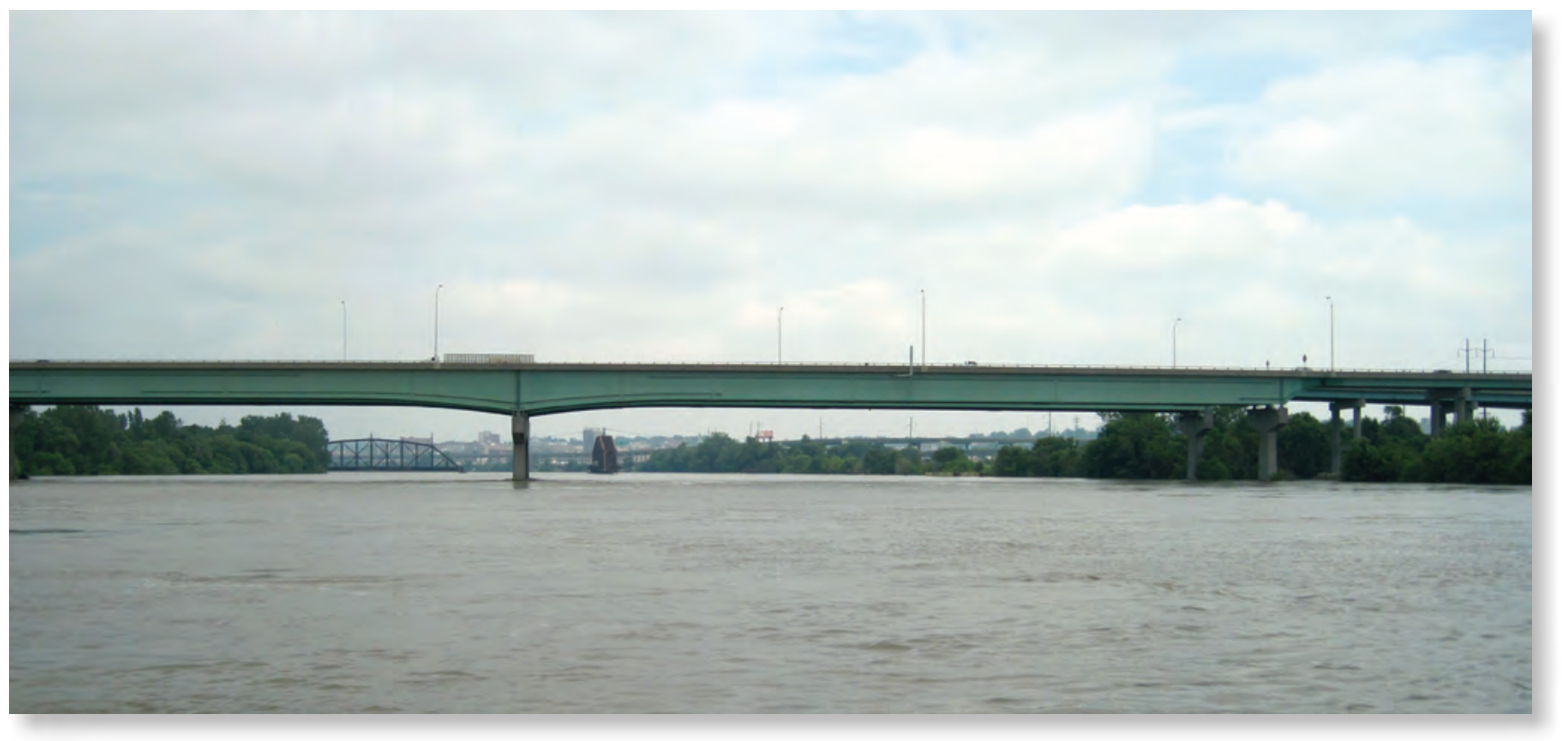

Dual bridge structure A3664 on U.S. Highway 36 at St. Joseph, Missouri. 


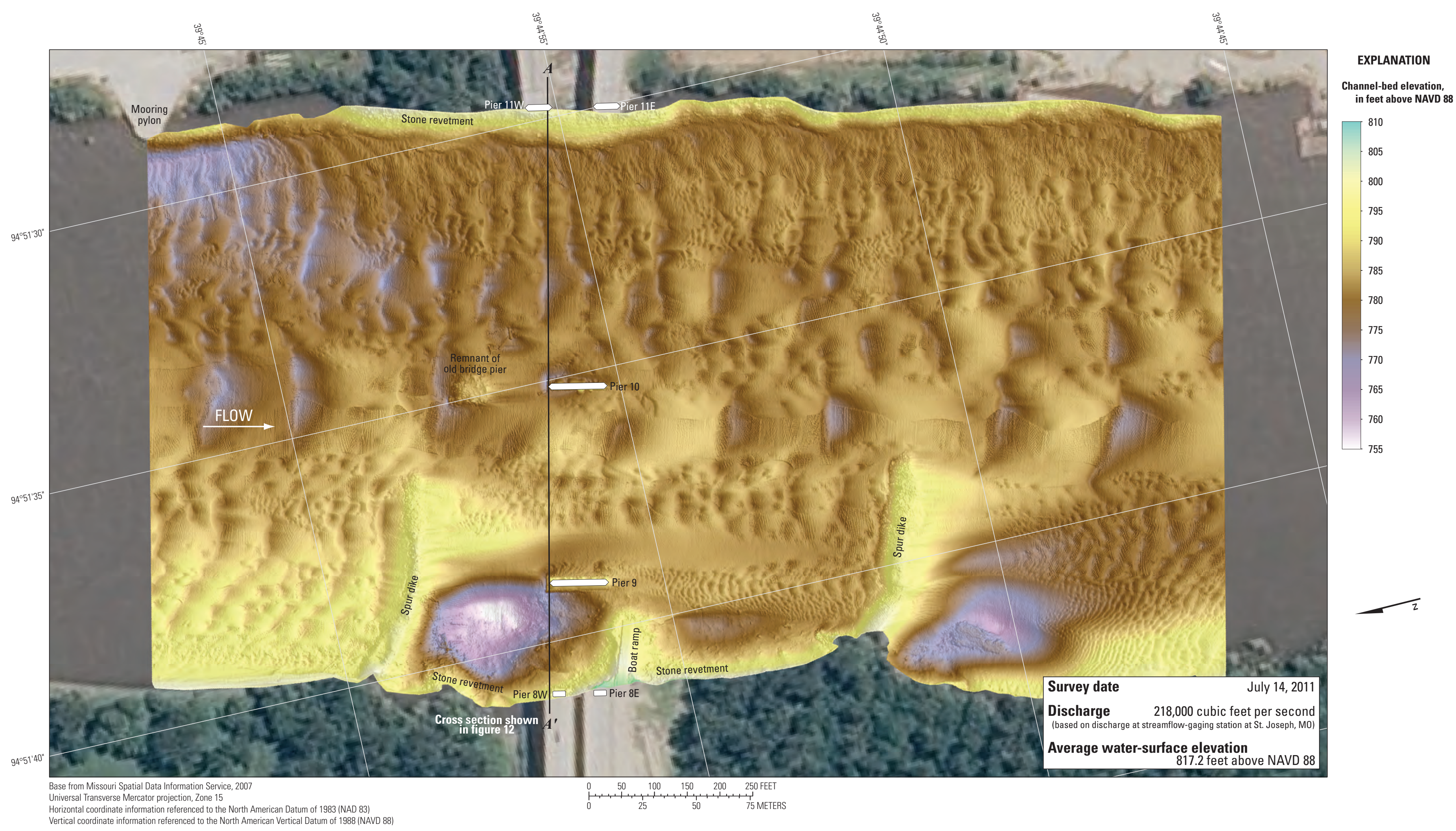

Figure 11. Bathymetric survey of the Missouri River channel in the vicinity of dual bridge structure A3664 on U.S. Highway 36 at St. Joseph, Missouri. 


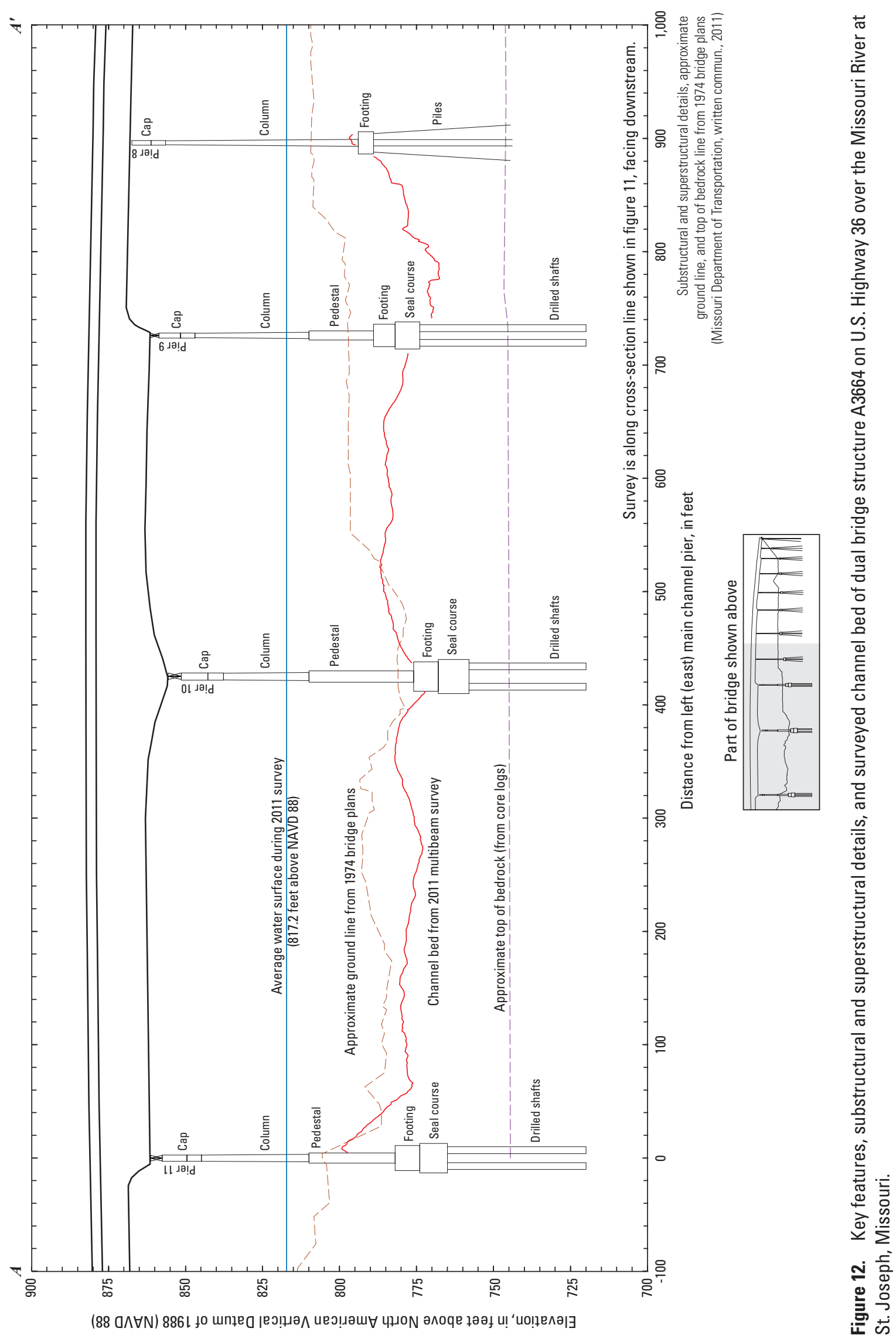




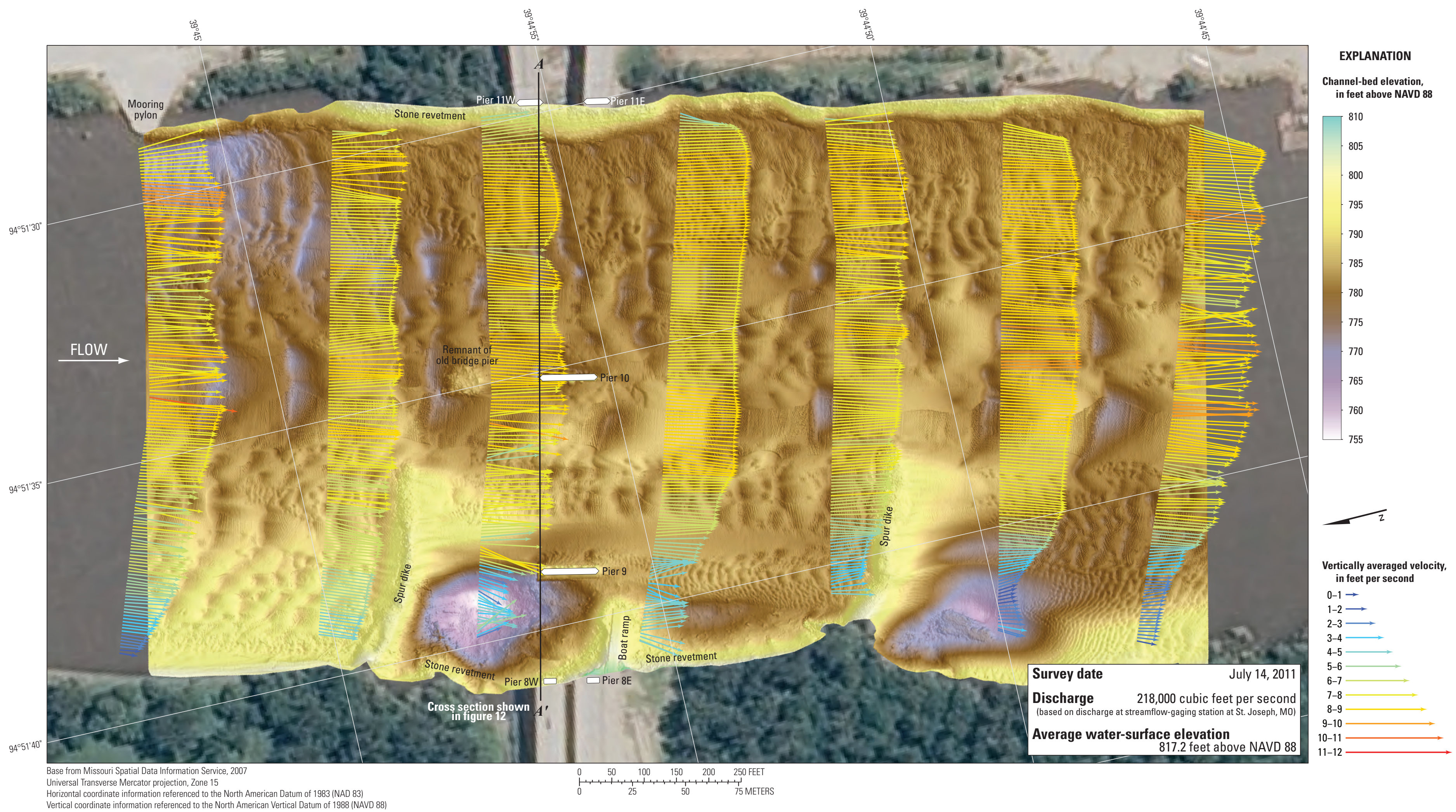

Figure 13. Bathymetry and vertically averaged velocities of the Missouri River channel in the vicinity of dual bridge structure A3664 on U.S. Highway 36 at St. Joseph, Missouri. 


\section{Structure 59-3-16.38 (013) on U.S. Highway 59 at Atchison, Kansas}

Structure 59-3-16.38 (013) (site 3) on U.S. Highway 59 crosses the Missouri River at RM 422.5 at Atchison, Kansas, to the western side of Missouri between St. Joseph and Kansas City (fig. 1). The site was surveyed on July 15, 2011; the average water-surface elevation of the river in the survey area, determined by the RTK GPS tide solution, was $792.4 \mathrm{ft}$ (table 5). Flow on the Missouri River was about 214,000 $\mathrm{ft}^{3} / \mathrm{s}$ during the survey, according to the streamgage at St. Joseph, Missouri (table 5).

The survey area was about $1,350 \mathrm{ft}$ long and about $660 \mathrm{ft}$ wide, extending across the active channel from bank to bank, but was limited by floating construction crane barges moored on the downstream left bank and the railroad bridge just upstream from structure 59-3-16.38 (013) (fig. 14). The elevation of the railroad bridge did not have sufficient clearance to permit surveying under it, except where the width of the survey swath reached under the bridge as the boat passed laterally along the downstream face of the railroad bridge. Therefore, the upstream end of the survey area was about $235 \mathrm{ft}$ upstream from the centerline of structure 59-3-16.38 (013) (fig. 14). The channel-bed elevations ranged from about 729 to $769 \mathrm{ft}$ for most of the surveyed area (5 to 95 percentile range of the bathymetric data), except near pier 10 (fig. 14). The channel downstream from the bridge was covered with numerous medium and small dunes and ripples (fig. 14). Stone revetment was present on the right (west) bank throughout the reach (fig. 14).

In the vicinity of main channel pier 10, the scour hole had a minimum channel-bed elevation of approximately $705 \mathrm{ft}$ (table 6), about $34 \mathrm{ft}$ below the average channel bed to either side of the pier (fig. 14). This scour hole was substantially affected by local scour caused by the railroad bridge pier upstream (fig. 14). Information from bridge plans indicates that pier 10 is founded on a caisson on bedrock, with only about $4 \mathrm{ft}$ of bed material between the bottom of the scour hole and bedrock at the upstream face of pier 10 (fig. 15; table 6). In modern construction, bridge substructural elements usually are pinned or socketed to bedrock (American Association of State Highway Transportation Officials, 2012; Brown and others, 2010), but full exposure of usually buried substructural elements warrants special consideration and observation, particularly at an older bridge such as structure 59-3-16.38 (013).

Structure 59-3-16.38 (013) is the subject of an ongoing study wherein the channel is surveyed periodically by USGS with the MBES to observe the effects of construction of a new U.S. Highway 59 bridge immediately downstream. Although the final results of this study are not yet available, the periodic surveys completed to date provide additional bathymetric surfaces that can be compared to the survey from July 15, 2011. The difference between the surveys on July 15, 2011, and June 30, 2009, before construction of the new U.S. Highway 59 bridge began (fig. 16), indicates substantial scour of as much as $30 \mathrm{ft}$ has occurred throughout the channel, whereas deposition of as much as $20 \mathrm{ft}$ has occurred on the left bank. The average difference between the 2011 and 2009 bathymetric surfaces is $-8.87 \mathrm{ft}$ (table 7), indicating substantial scour overall, as might be expected given the water-surface elevation difference of $15 \mathrm{ft}$ and flow difference of $157,400 \mathrm{ft}^{3} / \mathrm{s}$ (table 7); however, the difference between the surveys on July 15, 2011, and June 30, 2010, near the peak of the 2010 flood (fig. 17), indicates a similar channel configuration between the two surveys, with deposition as much as $7 \mathrm{ft}$ throughout the channel and minor local scour of as much as $5 \mathrm{ft}$. The average difference between the 2011 and 2010 bathymetric surfaces is $+1.43 \mathrm{ft}$ (table 7), indicating moderate deposition overall. The area around the cofferdam of pier 5 of the new U.S. Highway 59 bridge had experienced substantial deposition between June 30, 2010 and July 15, 2011 (fig. 17), likely as a result of the removal of the cofferdam, which was causing a flow constriction between it and pier 10 of the existing U.S. Highway 59 bridge while it was in place. The removal of this constriction also may account for the overall deposition between 2010 and 2011, despite a water-surface elevation difference of nearly $4 \mathrm{ft}$ and a flow difference of $80,000 \mathrm{ft}^{3} / \mathrm{s}$ (table 7). In both of the difference maps (figs. 16, 17), the appearance of substantial deposition or scour on the sides of the piers and cofferdam (areas of bright red or dark blue on the sides) results from minor horizontal positional variances between the surveys.

The surveyed bed from 2011 was a nearly uniform 20-25 ft lower than the surveyed bed from 2009 before construction of the new U.S. Highway 59 bridge began (fig. 15); however, the surveyed bed from 2011 was about $1-4 \mathrm{ft}$ higher than the surveyed bed from 2010 near the 2010 flood peak, despite the fact that the 2011 flood had a higher flow rate and water-surface elevation than 2010.

The vertically averaged velocity vectors indicated substantial turbulence in the vicinity of the railroad and U.S. Highway 59 bridges. Downstream from the railroad bridge turntable pier, the velocity reached a local maximum of nearly $12 \mathrm{ft} / \mathrm{s}$, but also dropped to about $5 \mathrm{ft} / \mathrm{s}$ about $20 \mathrm{ft}$ to the right, downstream from the railroad bridge turntable pier (fig. 18). Most of the turbulence and local high velocity values abated in the downstream part of the reach, with average velocities between 6 and $9 \mathrm{ft} / \mathrm{s}$ in the channel and between 3 and $5 \mathrm{ft} / \mathrm{s}$ along the left bank. There also was substantial turbulence downstream from pier 10 of the existing bridge and pier 5 of the new bridge (fig. 18).

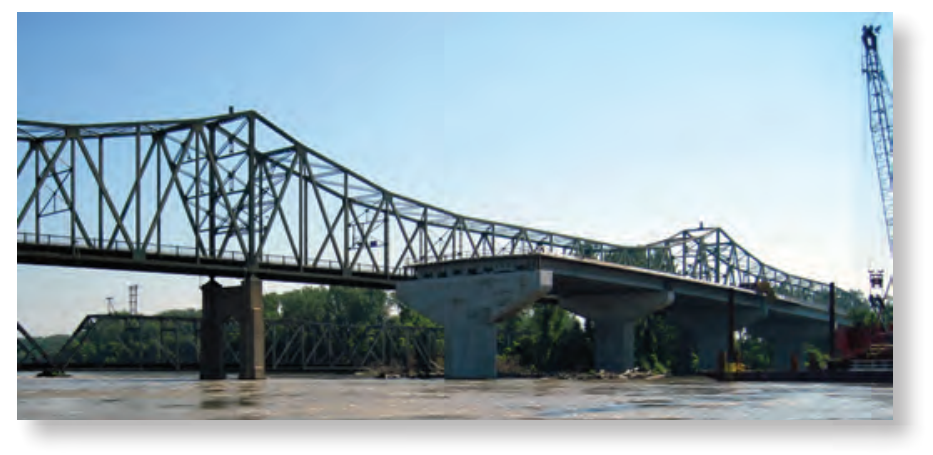

Structure 59-3-16.38 (013) on U.S. Highway 59 at Atchison, Kansas. The new U.S. Highway 59 bridge is being constructed in the foreground, and the Atchison railroad bridge is in the background. 


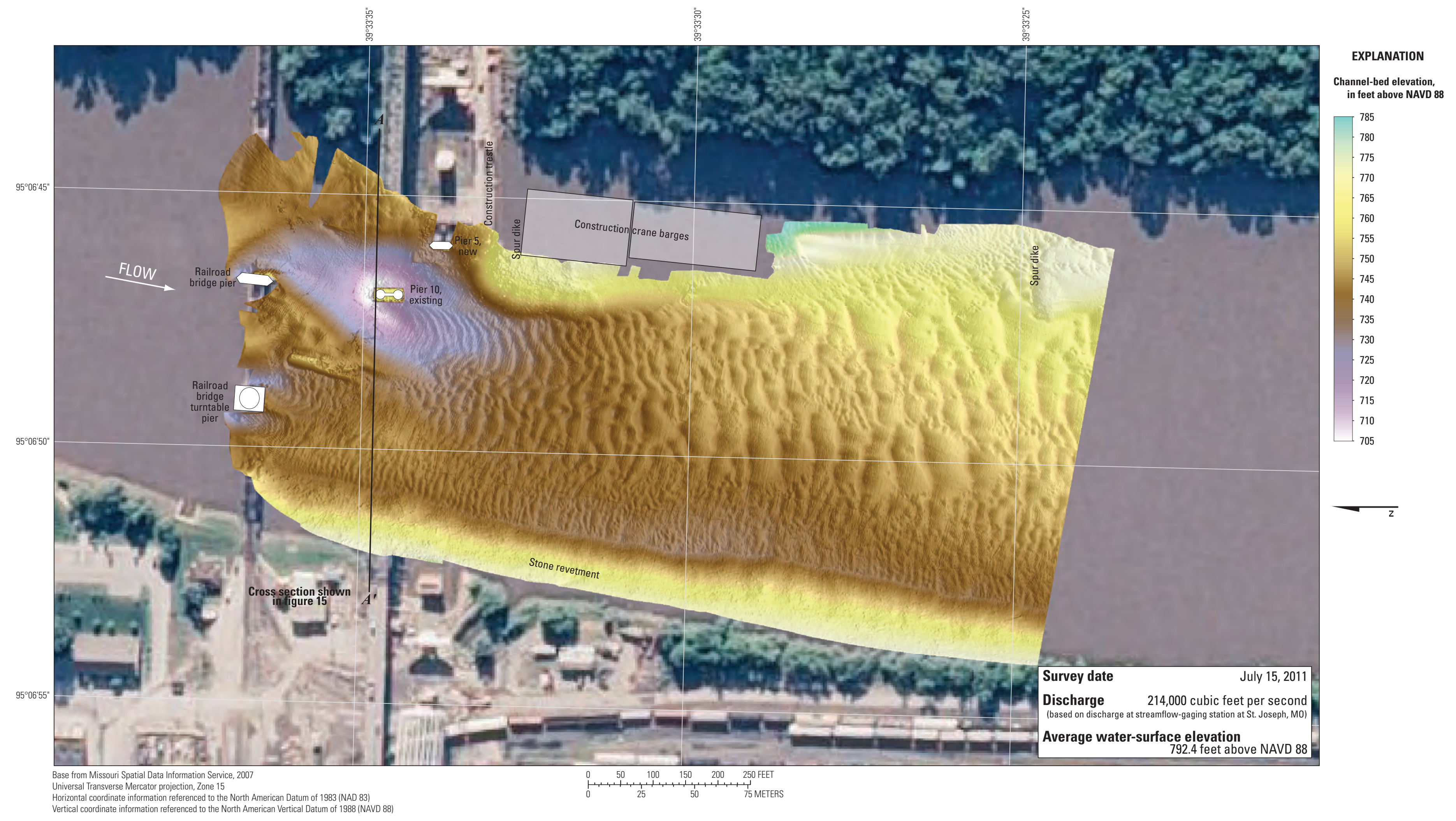

Figure 14. Bathymetric survey of the Missouri River channel in the vicinity of structure 59-3-16.38 (013) on U.S. Highway 59 at Atchison, Kansas. 


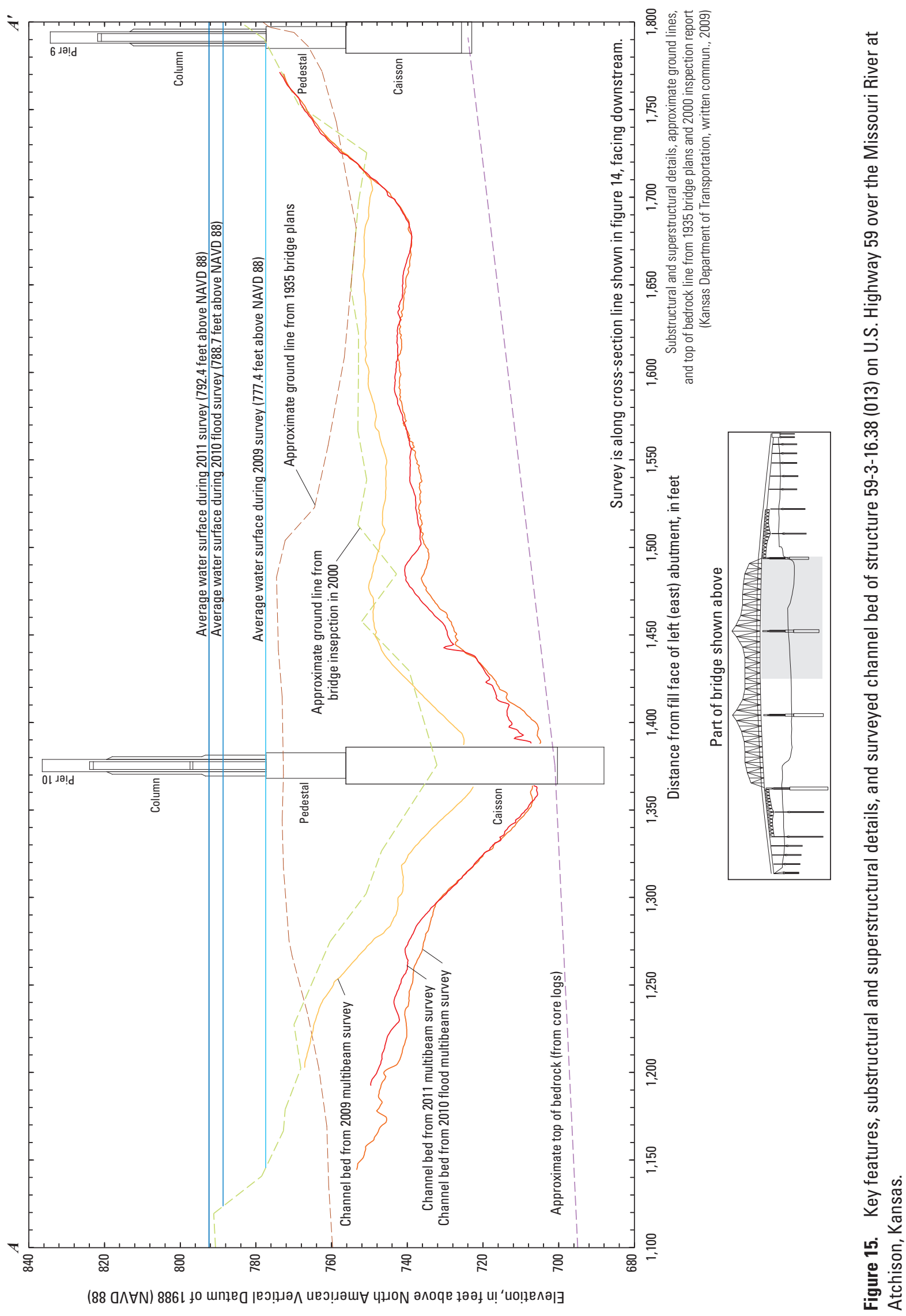




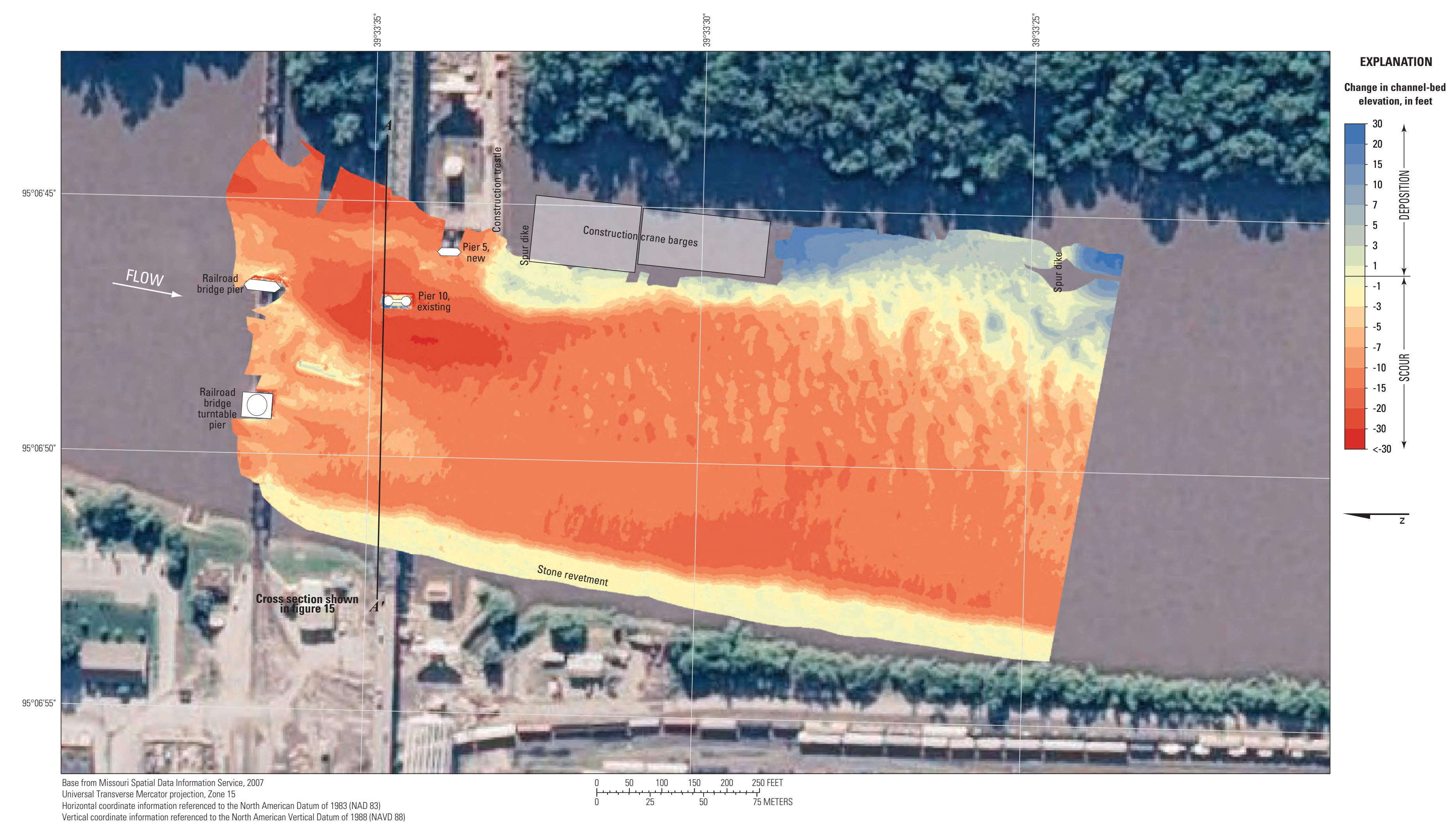

Figure 16. Difference between surfaces created from bathymetric surveys of the Missouri River channel in the vicinity of structure 59-3-16.38 (013) on U.S. Highway 59 at Atchison, Kansas, on June 30, 2009 , and July 15, 2011. 


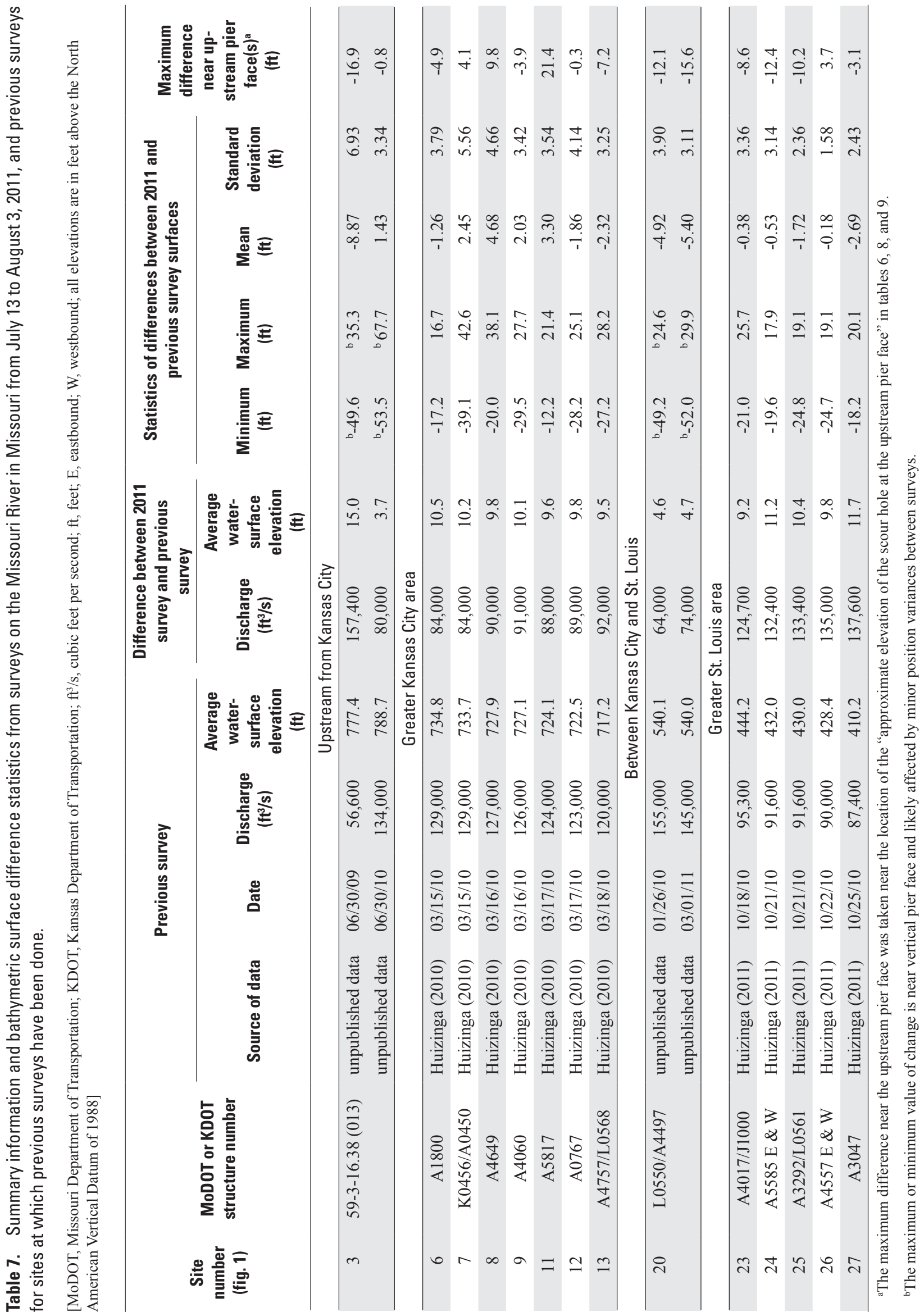




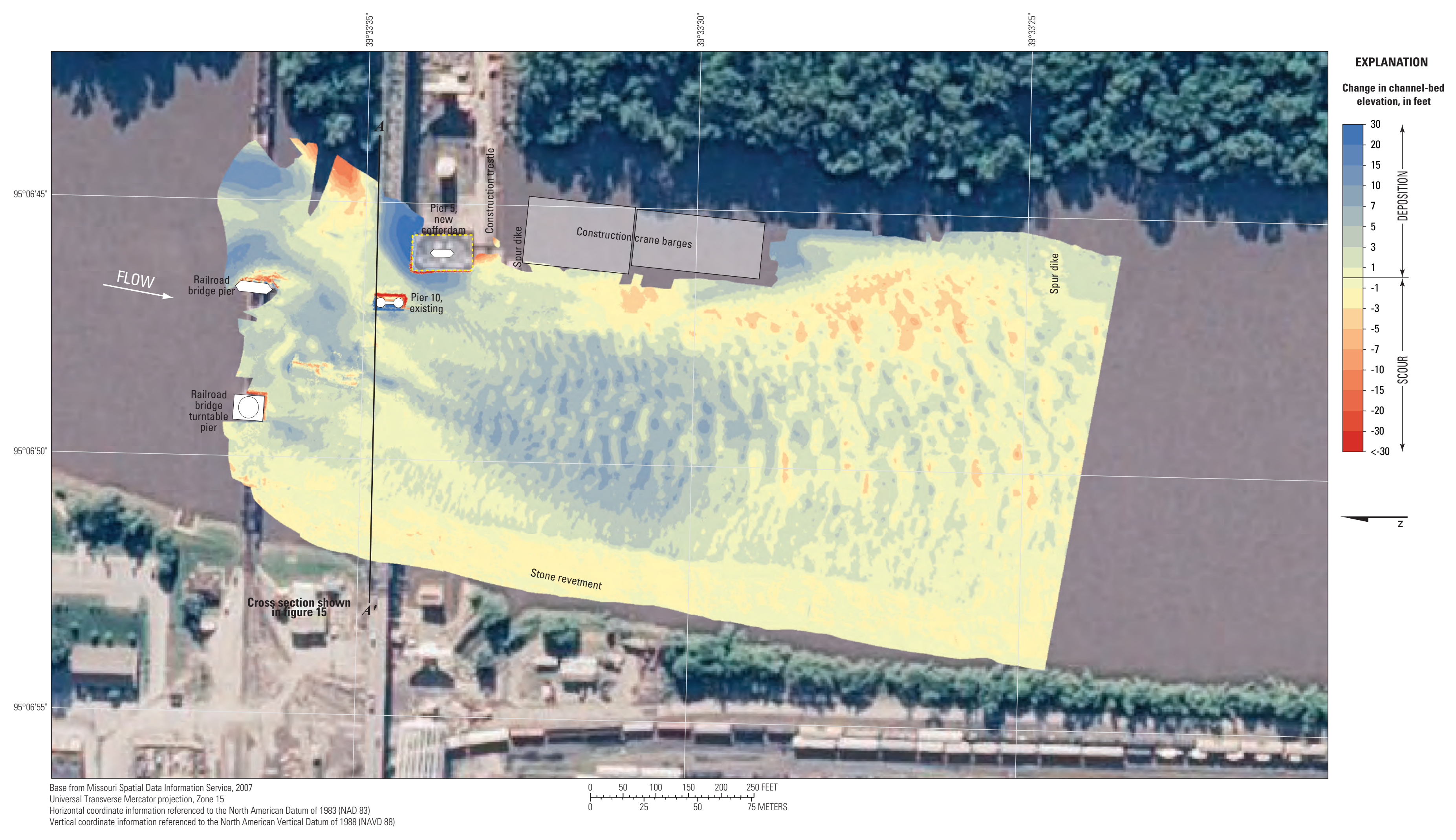

Figure 17. Difference between surfaces created from bathymetric surveys of the Missouri River channel in the vicinity of structure 59-3-16.38 (013) on U.S. Highway 59 at Atchison, Kansas, on June 30, 2010, and July 15, 2011 . 


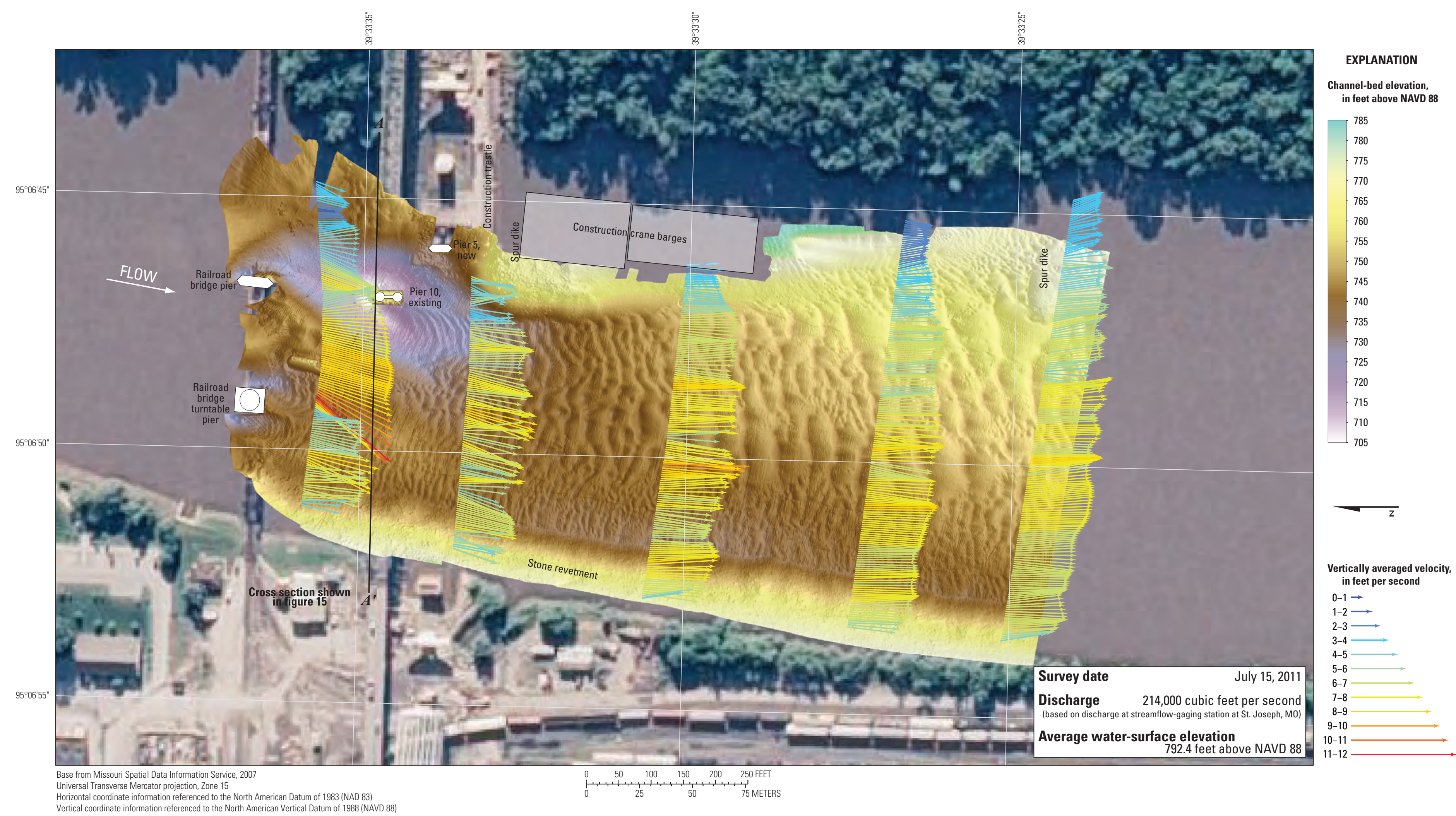

Figure 18. Bathymetry and vertically averaged velocities of the Missouri River channel in the vicinity of structure 59-3-16.38 (013) on U.S. Highway 59 at Atchison, Kansas. 


\section{Structure 92-52-18.48 (026) on State Highway 92 at Leavenworth, Kansas}

Structure 92-52-18.48 (026) (site 4) on State Highway 92 crosses the Missouri River at RM 397.5 at Leavenworth, Kansas, to the western side of Missouri just north of Kansas City (fig. 1). The site was surveyed on July 15, 2011; the average water-surface elevation of the river in the survey area, determined by the RTK GPS tide solution, was $770.9 \mathrm{ft}$ (table 5). Flow on the Missouri River was about $214,000 \mathrm{ft}^{3} / \mathrm{s}$ during the survey, according to the streamgage at St. Joseph, Missouri (table 5).

The survey area was about $1,640 \mathrm{ft}$ long and about $870 \mathrm{ft}$ wide, extending across the active channel from bank to bank (fig. 19). The upstream end of the survey area was about $700 \mathrm{ft}$ upstream from the centerline of structure 92-52-18.48 (026) (fig. 19). The channel-bed elevations ranged from about 722 to $745 \mathrm{ft}$ for most of the surveyed area ( 5 to 95 percentile range of the bathymetric data), except near pier 2 and on the downstream sides of the various spur dikes on the left (east) bank (fig. 19). The overall minimum channel elevation of $707.0 \mathrm{ft}$ was in a hole downstream from a spur dike located downstream from the bridge (fig. 19). A localized deep trough on the right (west) bank downstream from the bridge had a minimum channel-bed elevation of about $721 \mathrm{ft}$ (fig. 19). The channel bed had very large dune features along the left (east) bank, and a localized hole between two such features upstream from the bridge had a minimum channel-bed elevation of about $715 \mathrm{ft}$ (fig. 19). The rest of the channel bed was covered with large, medium and small dunes and ripples (fig. 19).
Stone revetment was present on the upstream left (east) bank, and on the downstream right (west) bank (fig. 19).

In the vicinity of main channel pier 2 , a local scour hole had a minimum channel-bed elevation of about $716 \mathrm{ft}$ (table 6), about $17 \mathrm{ft}$ below the average channel bed immediately upstream from the pier (fig. 19). Information from bridge plans indicates that pier 2 is founded on footings on bedrock, with about $12 \mathrm{ft}$ of bed material between the bottom of the scour hole and bedrock at the upstream face of the pier (fig. 20; table 6). In the vicinity of main channel pier 3, a local scour hole caused in part by the adjacent spur dike had a minimum channel-bed elevation of about $720 \mathrm{ft}$ (table 6), but the deepest part of the hole was located downstream from and $40 \mathrm{ft}$ to the right of pier 3 (figs. 19, 20). There was no observable scour hole near pier 3 that could be directly attributed to the pier (figs. 19, 20). There also was no observable scour hole near pier 1 on the right bank (figs. 19, 20). The surveyed bed generally was lower than the original ground line from bridge plans at the time of construction (1952) at this site, and the surveyed channel appeared to be more narrow than the channel at the time of construction, especially on the right (west) bank (fig. 20).

The vertically averaged velocity vectors indicated mostly uniform flow, with velocities ranging from 5 to $9 \mathrm{ft} / \mathrm{s}$ in the main channel, except along the banks and downstream from the spur dikes (fig. 21). Velocities reached a local maximum of almost $11 \mathrm{ft} / \mathrm{s}$ near the crest of the very large dune features and the shallow areas on the left (east) side of the channel (fig. 21). The turbulence downstream from main channel pier 2 was not pronounced, and appeared to be no greater than the general turbulence observed in the channel upstream from the pier (fig. 21).

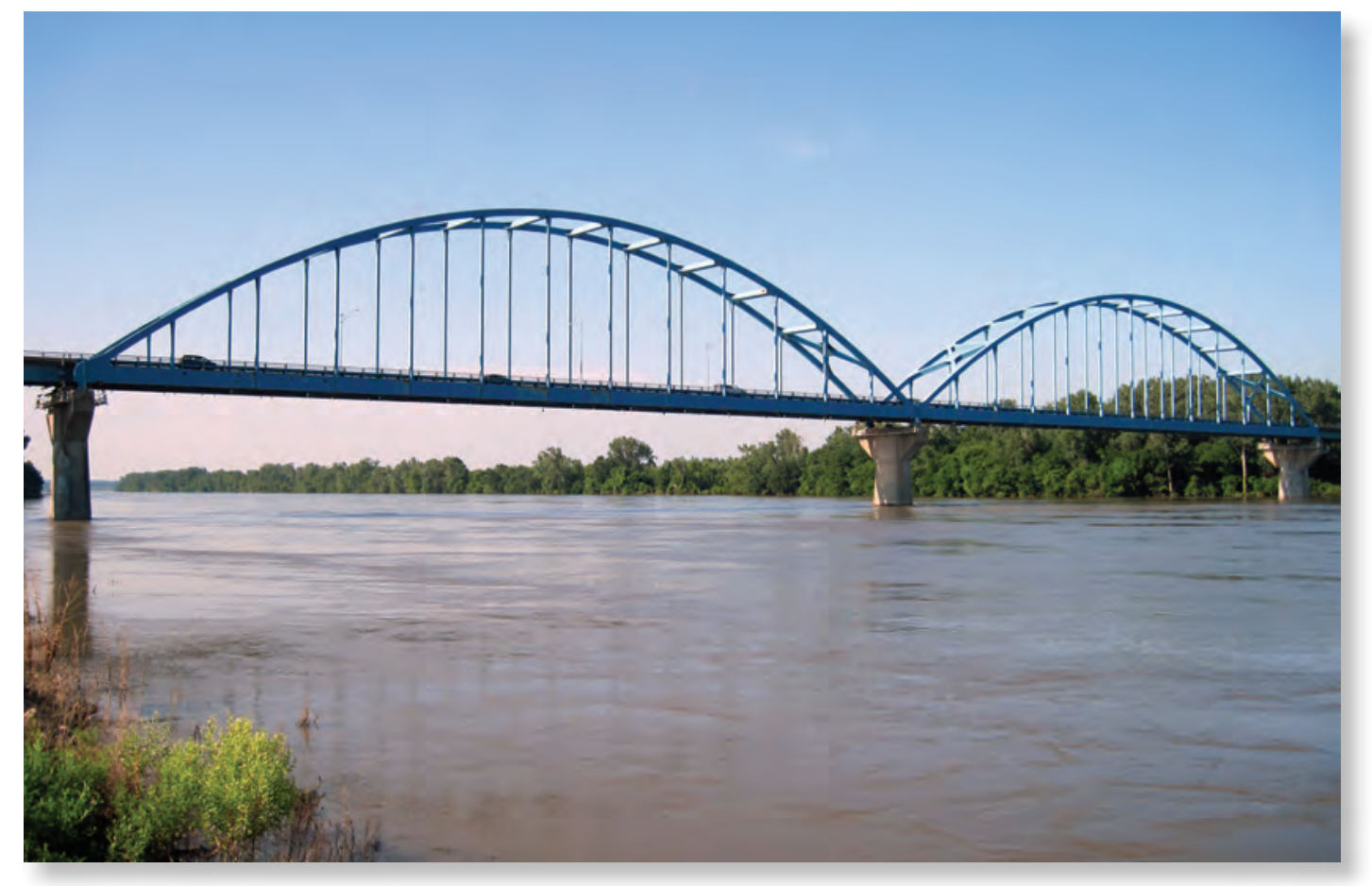

Structure 92-52-18.48 (026) on State Highway 92 at Leavenworth, Kansas. 


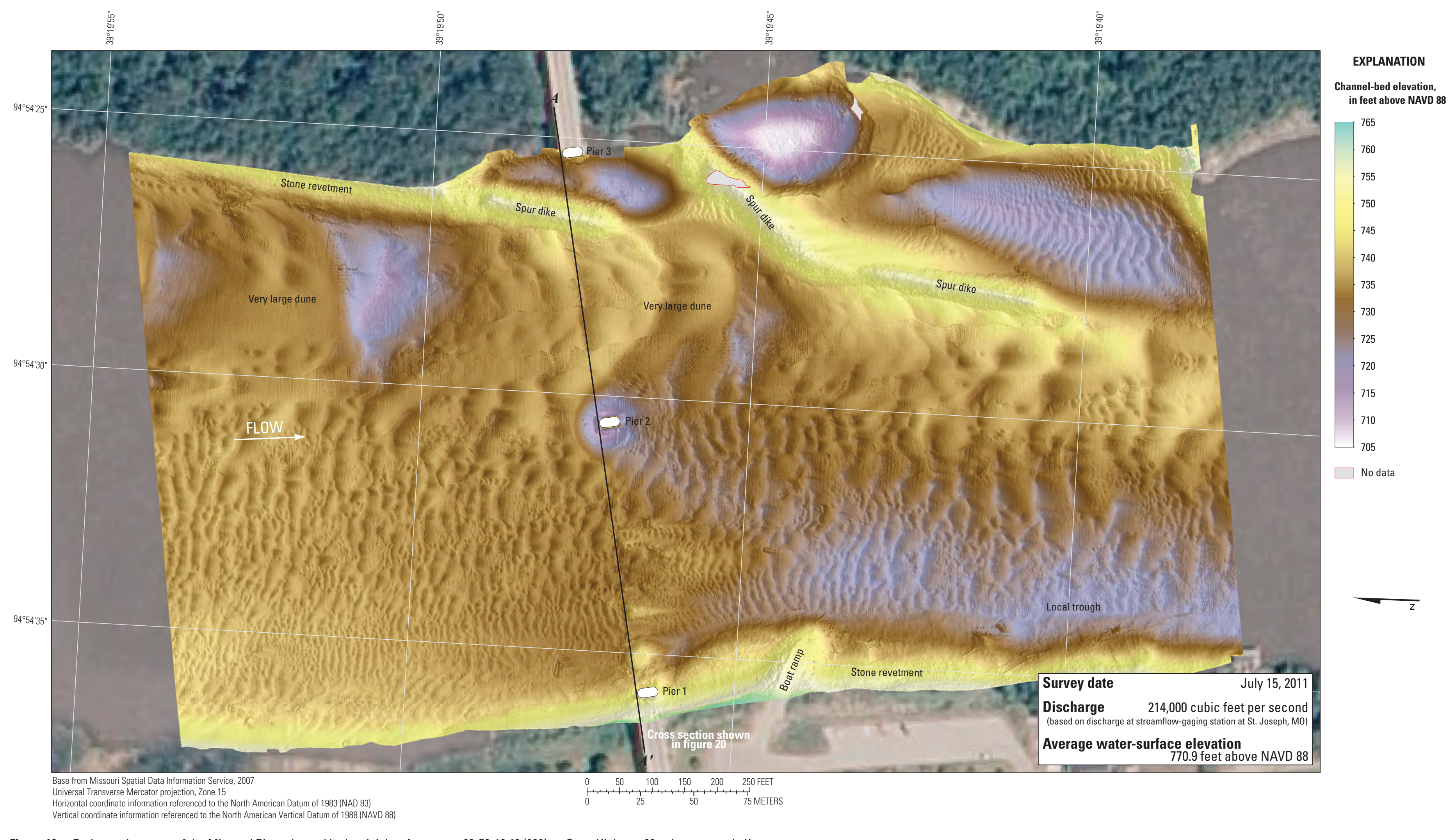

Figure 19. Bathymetric survey of the Missouri River channel in the vicinity of structure 92-52-18.48 (026) on State Highway 92 at Leavenworth, Kansas. 


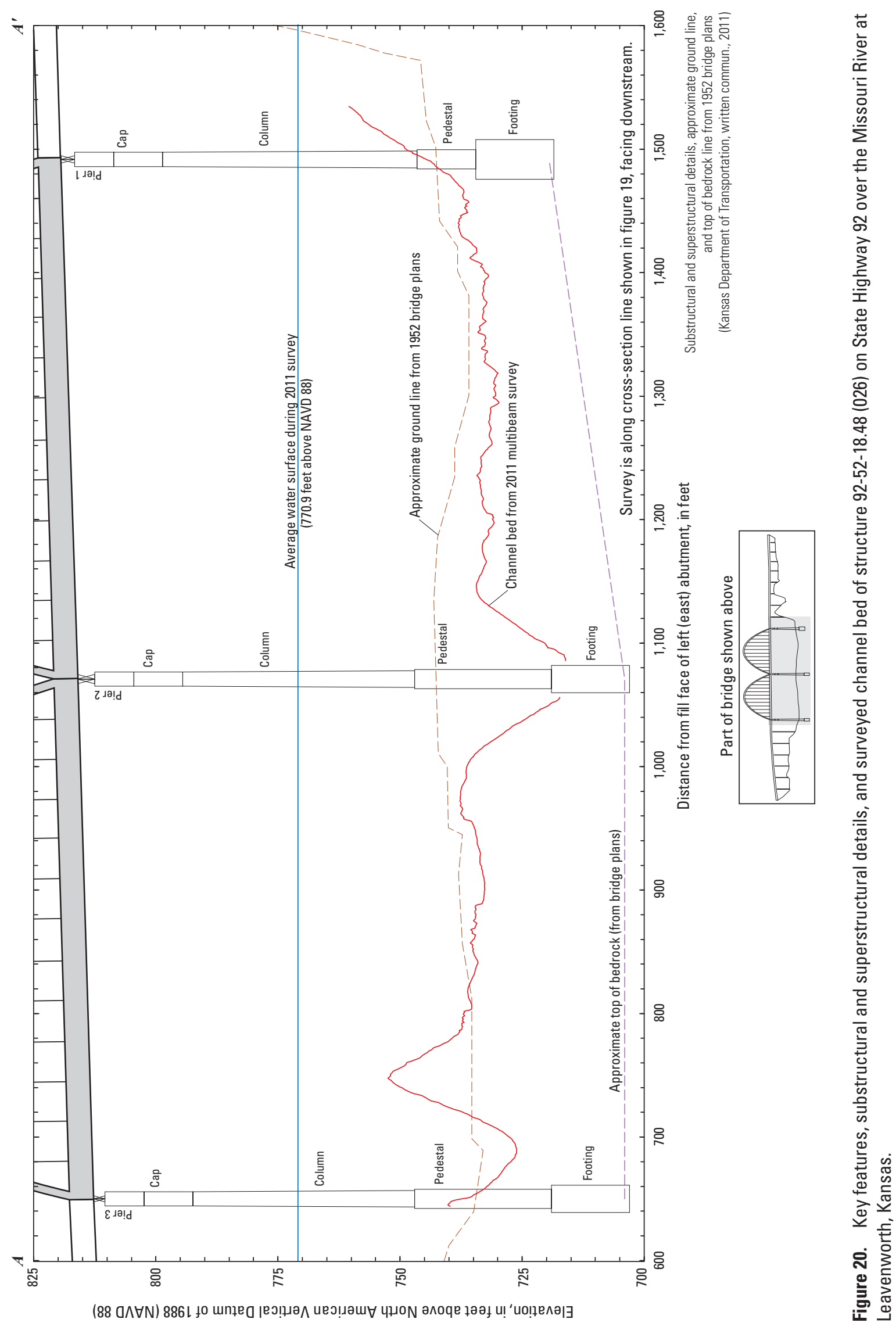




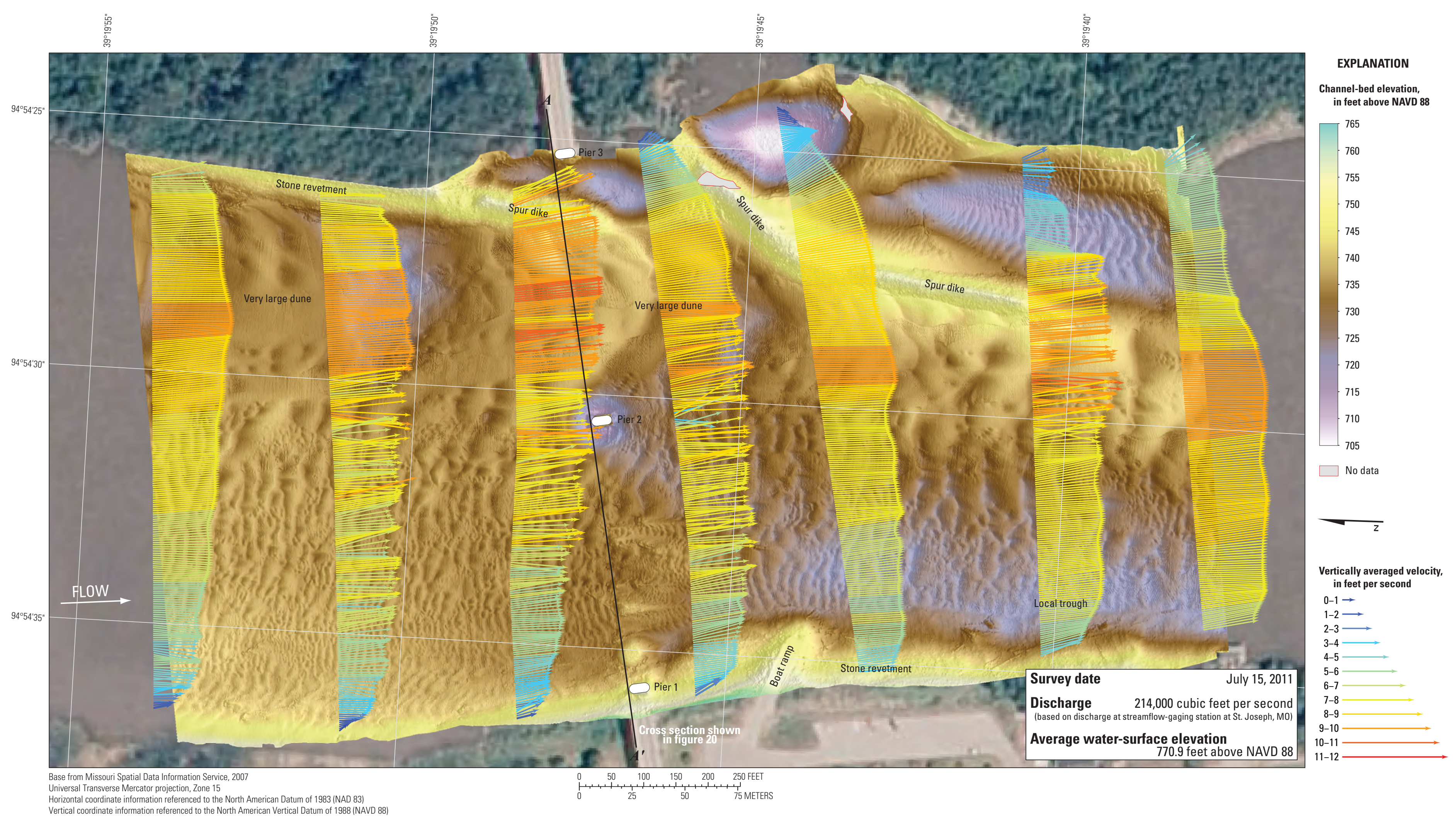

Figure 21. Bathymetry and vertically averaged velocities of the Missouri River channel in the vicinity of structure 92-52-18.48 (026) on State Highway 92 at Leavenworth, Kansas. 


\section{Greater Kansas City Area}

There are nine unique highway crossings of the Missouri River in the greater Kansas City area on the western side of Missouri (table 1; fig. 1). Seven of these crossings have had previous bathymetric surveys (Huizinga, 2010).

\section{Structures 435-105-11.97 (235) and 435-105-11.98 (240) on Interstate 435 near Kansas City, Missouri}

Structures 435-105-11.97 (235) and 435-105-11.98 (240) (site 5) on Interstate 435 cross the Missouri River at RM 383.4 near Parkville, Missouri, on the northwestern side of the greater Kansas City area (fig. 1). The site was surveyed on July 16, 2011; the average water-surface elevation of the river in the survey area, determined by the RTK GPS tide solution, was $756.1 \mathrm{ft}$ (table 5). Flow on the Missouri River was about $213,000 \mathrm{ft}^{3} / \mathrm{s}$ during the survey, according to the streamgage at St. Joseph, Missouri (table 5).

The survey area was about 1,640 ft long and about $690 \mathrm{ft}$ wide, extending across the active channel from bank to bank (fig. 22). The upstream end of the survey area was about $695 \mathrm{ft}$ upstream from the centerline of structures 435-105-11.97 (235) and 435-105-11.98 (240) (fig. 22). The channel-bed elevations ranged from about 705 to $728 \mathrm{ft}$ for most of the surveyed area ( 5 to 95 percentile range of the bathymetric data), with a local deep hole downstream from one very large dune feature that reached the overall minimum channel elevation of $693 \mathrm{ft}$ (fig. 22; table 5). The Missouri River is in a gradual bend to the right upstream from this site, resulting in a channel thalweg along the left (east) bank and generally shallow areas upstream from the spur dikes along the right (west) bank (fig. 22). There were several very large dune features in the middle of the upstream channel, with numerous large, medium, and small dunes and ripples throughout the rest of the channel (fig. 22). Stone revetment was present on the left (east) bank (fig. 22).

Main channel pier 9 appeared to be surrounded by a mound of rock riprap, with a local minimum channel-bed elevation of about $709 \mathrm{ft}$ to the left of the pier and riprap (figs. 22, 23; table 6). The top of the rock riprap around the upstream face of the pier was at an elevation of about $719 \mathrm{ft}$, which is equal to or slightly above the average channel bed immediately upstream from the pier (figs. 22, 23); another pile of rock riprap was present upstream from the pier (fig. 22). Information from bridge plans indicates that pier 9 is founded on shafts drilled about $4 \mathrm{ft}$ into bedrock, with about $49 \mathrm{ft}$ of bed material between the bottom of the scour hole and bedrock (fig. 23; table 6). The surveyed bed generally was 5 to $10 \mathrm{ft}$ lower than the original ground line from bridge plans at the time of construction (1974) in the channel to the left of pier 9, but was substantially higher than the original ground line in the channel to the right of pier 9 (fig. 23).

The vertically averaged velocity vectors indicate mostly uniform flow at between 8 and $10 \mathrm{ft} / \mathrm{s}$ in the main channel, with a few local velocities reaching $11 \mathrm{ft} / \mathrm{s}$, and lower values along the banks, particularly along the right (west) bank and downstream from the spur dikes (fig. 24). Pier 9 is aligned with the flow, and there was more turbulence in the upstream reach and immediately upstream from the bridge than downstream from the pier (fig. 24).

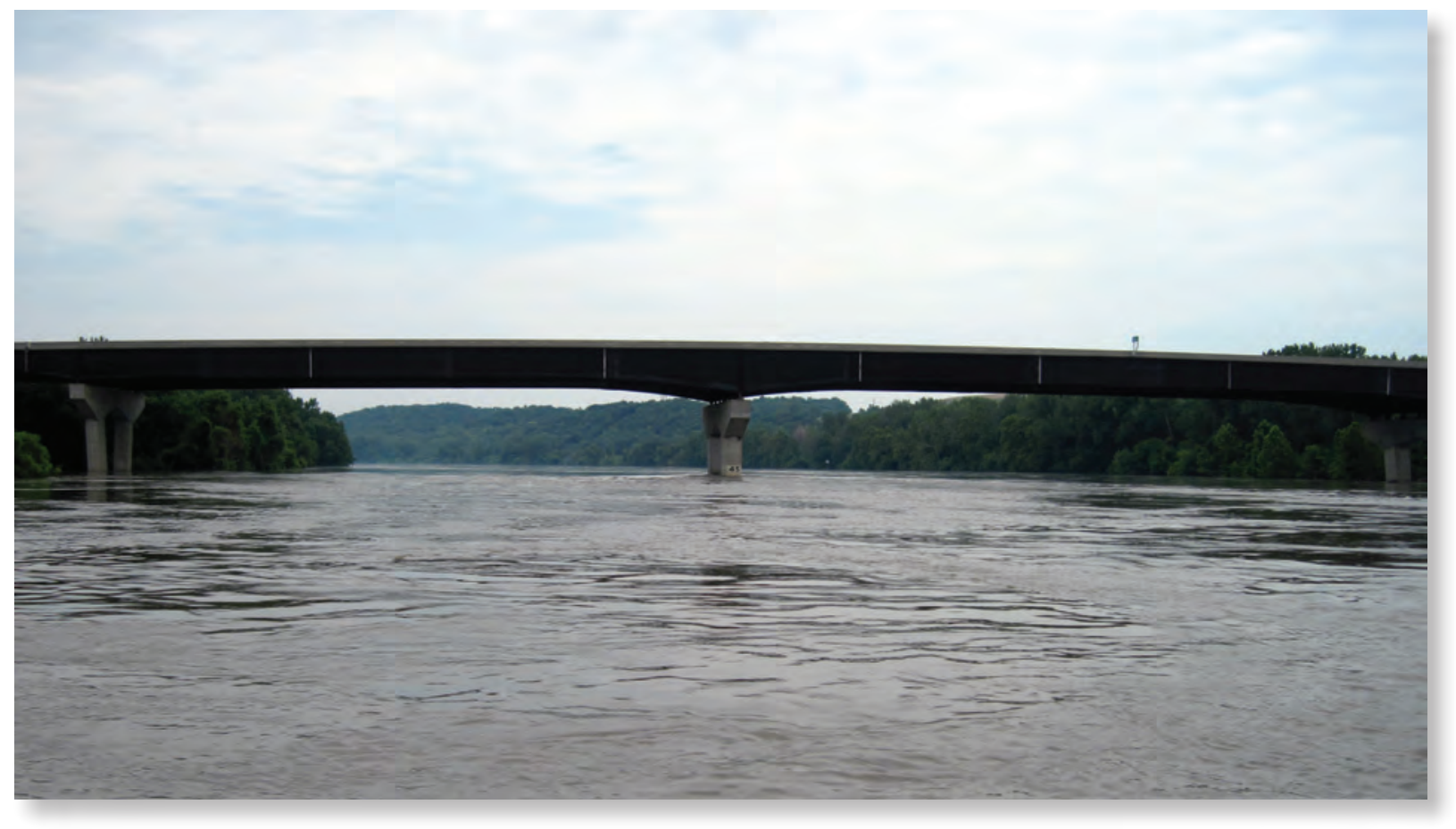

Structures 435-105-11.97 (235) and 435-105-11.98 (240) on Interstate 435 near Kansas City, Missouri. Structure 435-105-11.98 (240) is in the foreground and structure 435-105-11.97 (235) is in the background. 


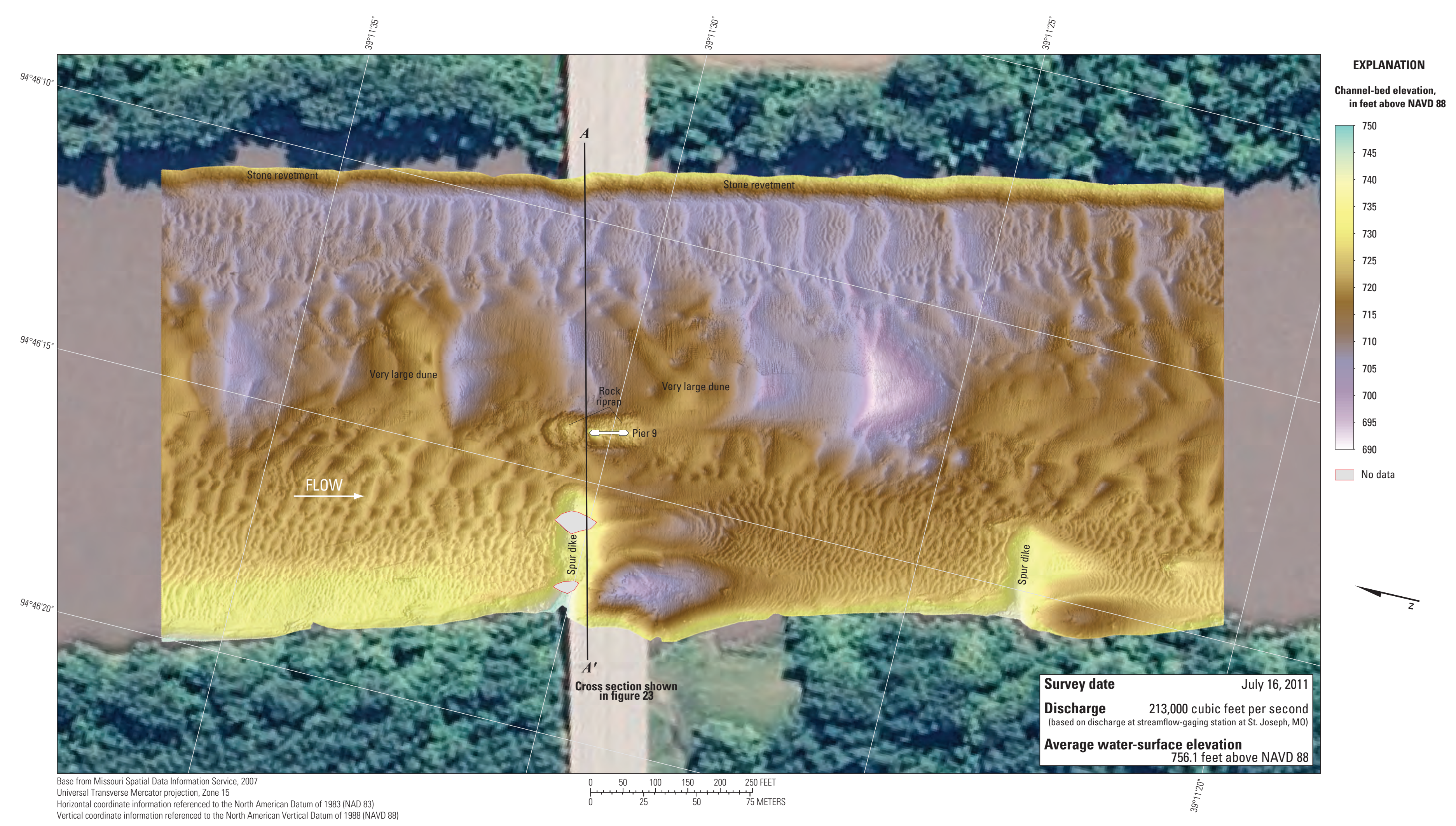

Figure 22. Bathymetric survey of the Missouri River channel in the vicinity of structures 435-105-11.97 (235) and 435-105-11.98 (240) on Interstate 435 near Kansas City, Missouri. 


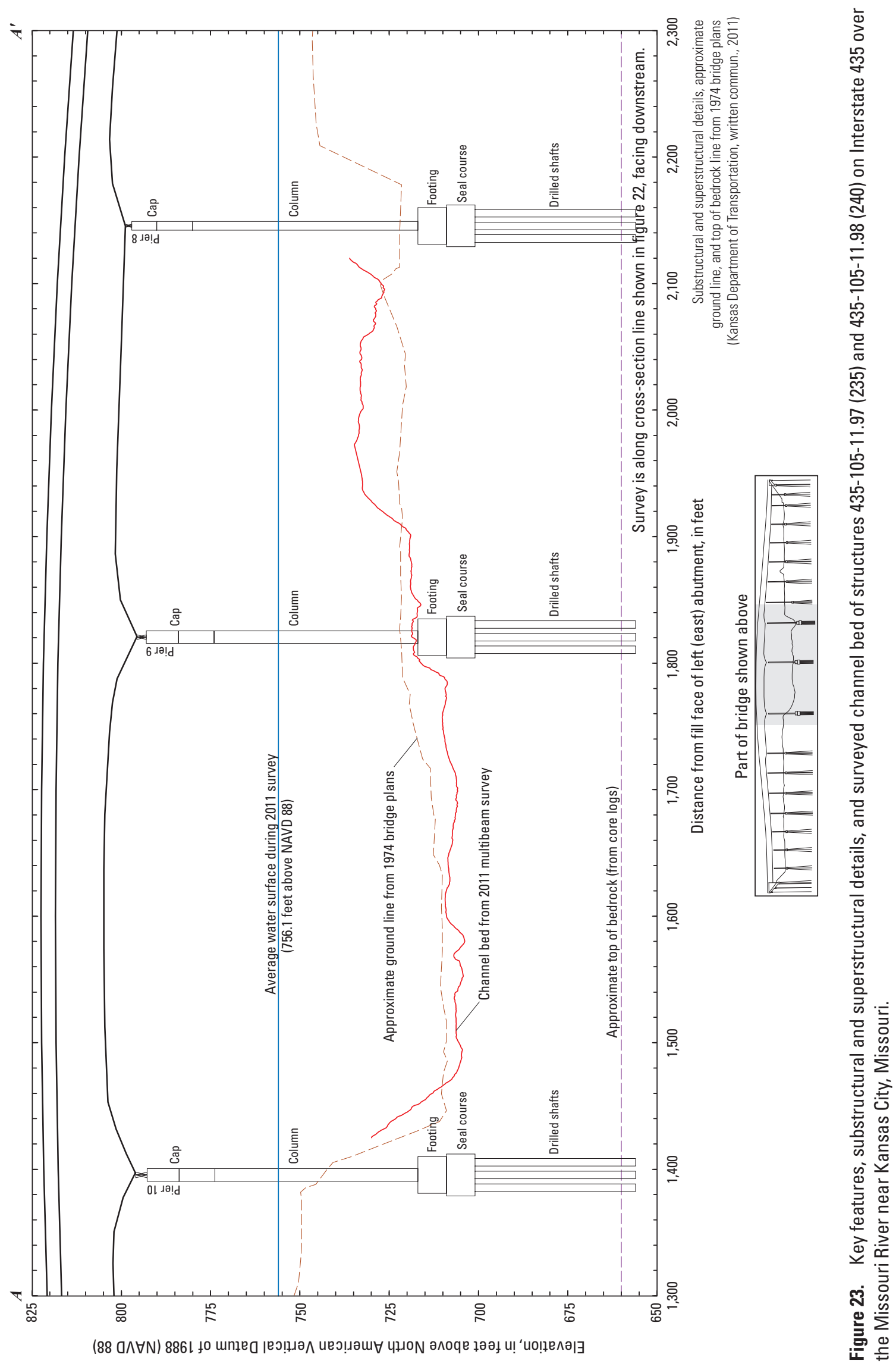




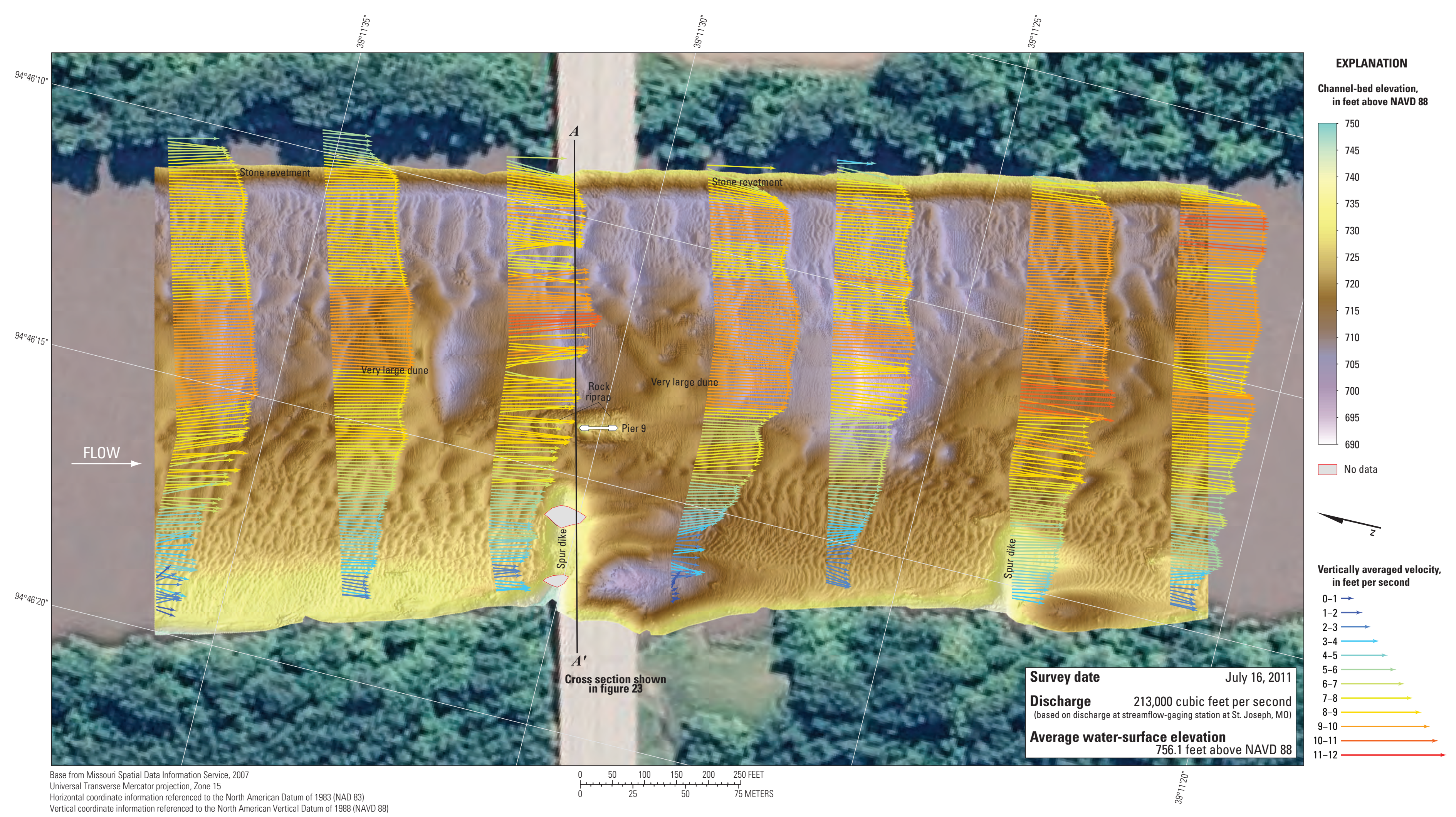

Figure 24. Bathymetry and vertically averaged velocities of the Missouri River channel in the vicinity of structures 435-105-11.97 (235) and 435-105-11.98 (240) on Interstate 435 near Kansas City, Missouri. 


\section{Structure A1800 on Interstate 635 in Kansas City, Missouri}

Structure A1800 (site 6) on Interstate 635 crosses the Missouri River at RM 374.1, on the northwestern side of Kansas City, Missouri (fig. 1). The site was surveyed on July 16, 2011; the average water-surface elevation of the river in the survey area, determined by the RTK GPS tide solution, was $745.3 \mathrm{ft}$ (table 5). Flow on the Missouri River was about $213,000 \mathrm{ft}^{3} / \mathrm{s}$ during the survey, according to the streamgage at St. Joseph, Missouri (table 5).

The survey area was about 1,640 ft long and about $720 \mathrm{ft}$ wide, extending across the active channel from bank to bank (fig. 25). The upstream end of the survey area was about $770 \mathrm{ft}$ upstream from the centerline of structure A1800 (fig. 25). The channel-bed elevations ranged from about 695 to $723 \mathrm{ft}$ for most of the surveyed area ( 5 to 95 percentile range of the bathymetric data; fig. 25). A deep thalweg along the outside of the channel bend on the right (south) bank was about $25 \mathrm{ft}$ deeper than the channel bed on the inside of the bend on the left (north) bank (fig. 25). Several very large dune features were detected in the middle of the channel, and the left (north) side was covered with numerous medium and small dunes and ripples (fig. 25). A rock outcrop and stone revetment were present on the right (south) bank throughout the reach (fig. 25).

In the vicinity of main channel pier 3 , the scour hole had a minimum channel-bed elevation of about $693 \mathrm{ft}$ (table 6), about $18 \mathrm{ft}$ below the average channel bed immediately upstream from the pier (fig. 26), and approximately $9 \mathrm{ft}$ below the elevation of the bottom of the pier seal course of $702.28 \mathrm{ft}$ (fig. 26; table 6). Information from bridge plans indicates that pier 3 is founded on shafts drilled $20 \mathrm{ft}$ into bedrock, with about $41 \mathrm{ft}$ of bed material between the bottom of the scour hole and bedrock at the upstream face of pier 3 (fig. 26; table 6).
The difference between the survey on July 16, 2011, and the previous survey on March 15, 2010 (fig. 27) indicates substantial variation from 2010 to 2011, particularly near the large dune features from the 2011 survey (fig. 25). Large dune features also were present in the 2010 survey (Huizinga, 2010), but their position was out-of-phase with the features from the 2011 survey. There appeared to be an area of net scour on the left (north) side in the upstream and downstream reaches, with an area of net deposition on the left side immediately downstream from the bridge (fig. 27). The average difference between the bathymetric surfaces was $-1.26 \mathrm{ft}$ (table 7 ), indicating overall scour occurred between the 2010 and 2011 surveys. The cross sections from the two surveys are not substantially different from one another (fig. 26), despite a water-surface elevation difference of more than $10 \mathrm{ft}$ and a flow difference of 84,000 $\mathrm{ft}^{3} / \mathrm{s}$ (table 7). The scour hole near pier 3 was slightly narrower and deeper in 2011 than in 2010 (fig. 26), as evidenced by the small area of scour at the upstream face and the overall pattern of deposition in a horseshoe shape around the pier (fig. 27). The rock outcrop on the upstream right (south) bank appeared to experience no change, as would be expected (fig. 27) —although rock ultimately is an erodible material, its rate of erosion is substantially slower than that of sand and silt (Richardson and Davis, 2001); however, the stone revetment on the downstream right (south) bank appeared to have degraded in some areas, likely from localized slumping (fig. 27). As with difference maps presented earlier in this report, the appearance of substantial deposition or scour at the faces of the pier result from minor horizontal positional variances between the surveys.

The vertically averaged velocity vectors indicate mostly uniform flow upstream from the bridge, with a maximum velocity of $12 \mathrm{ft} / \mathrm{s}$ in the channel thalweg and a minimum of $4 \mathrm{ft} / \mathrm{s}$ along the inside of the bend on the left (north) bank (fig. 28). Substantial turbulence was observed in the vicinity of pier 3, likely exacerbated by the pier being skewed to flow (fig. 28). A uniform flow pattern was present in the downstream-most section (fig. 28).

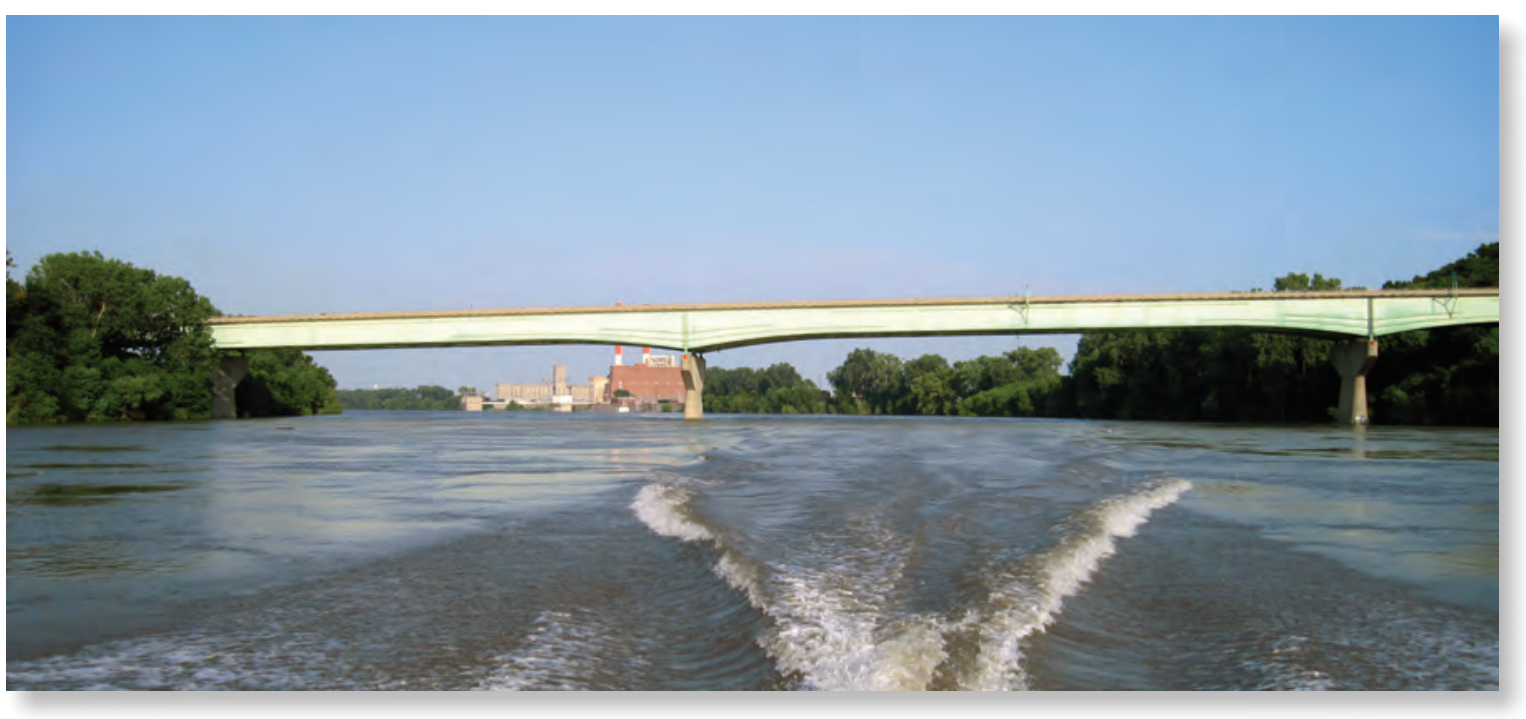

Structure A1800 on Interstate 635 in Kansas City, Missouri. 


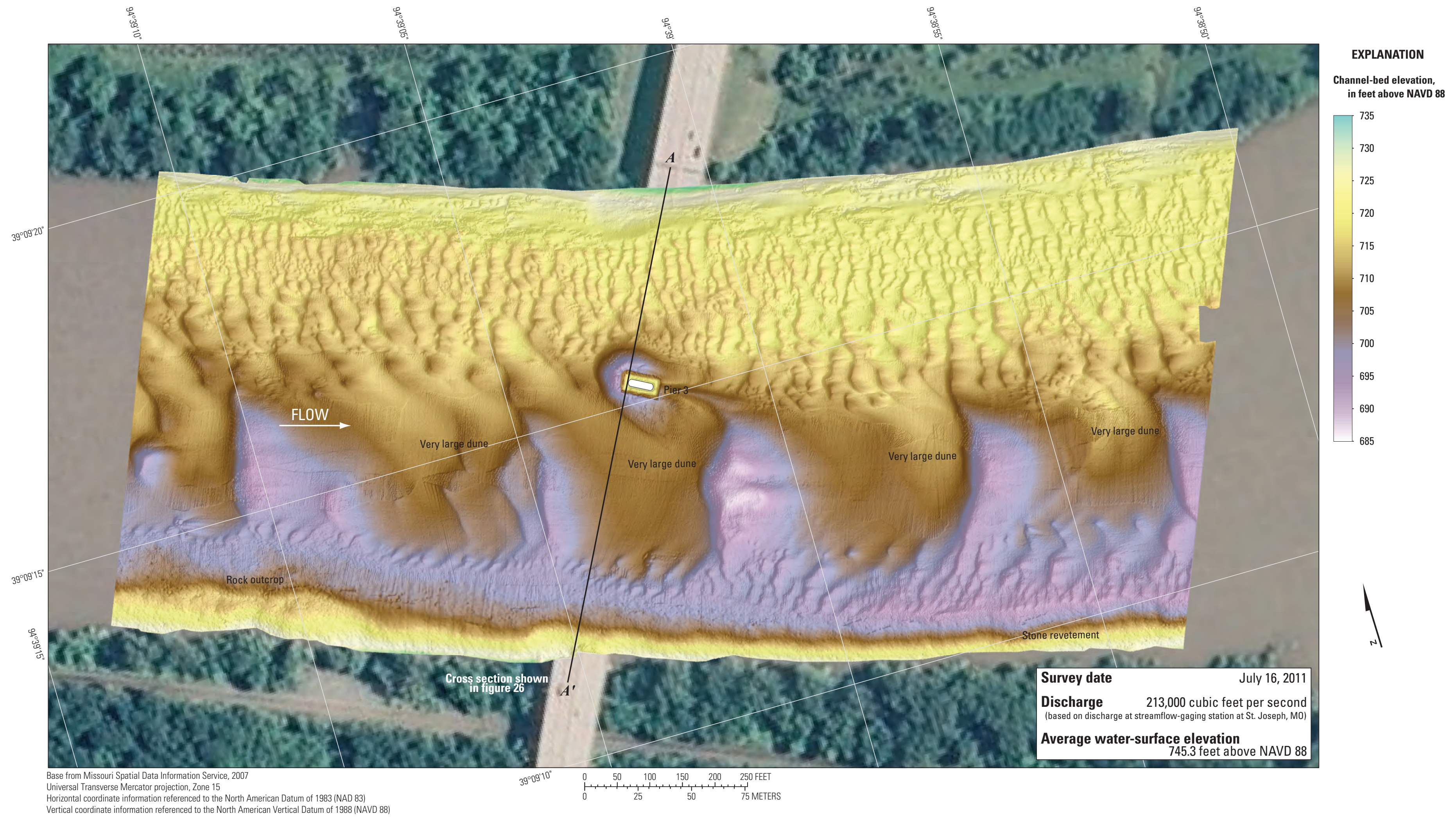

Figure 25. Bathymetric survey of the Missouri River channel in the vicinity of structure A1800 on Interstate 635 in Kansas City, Missouri. 


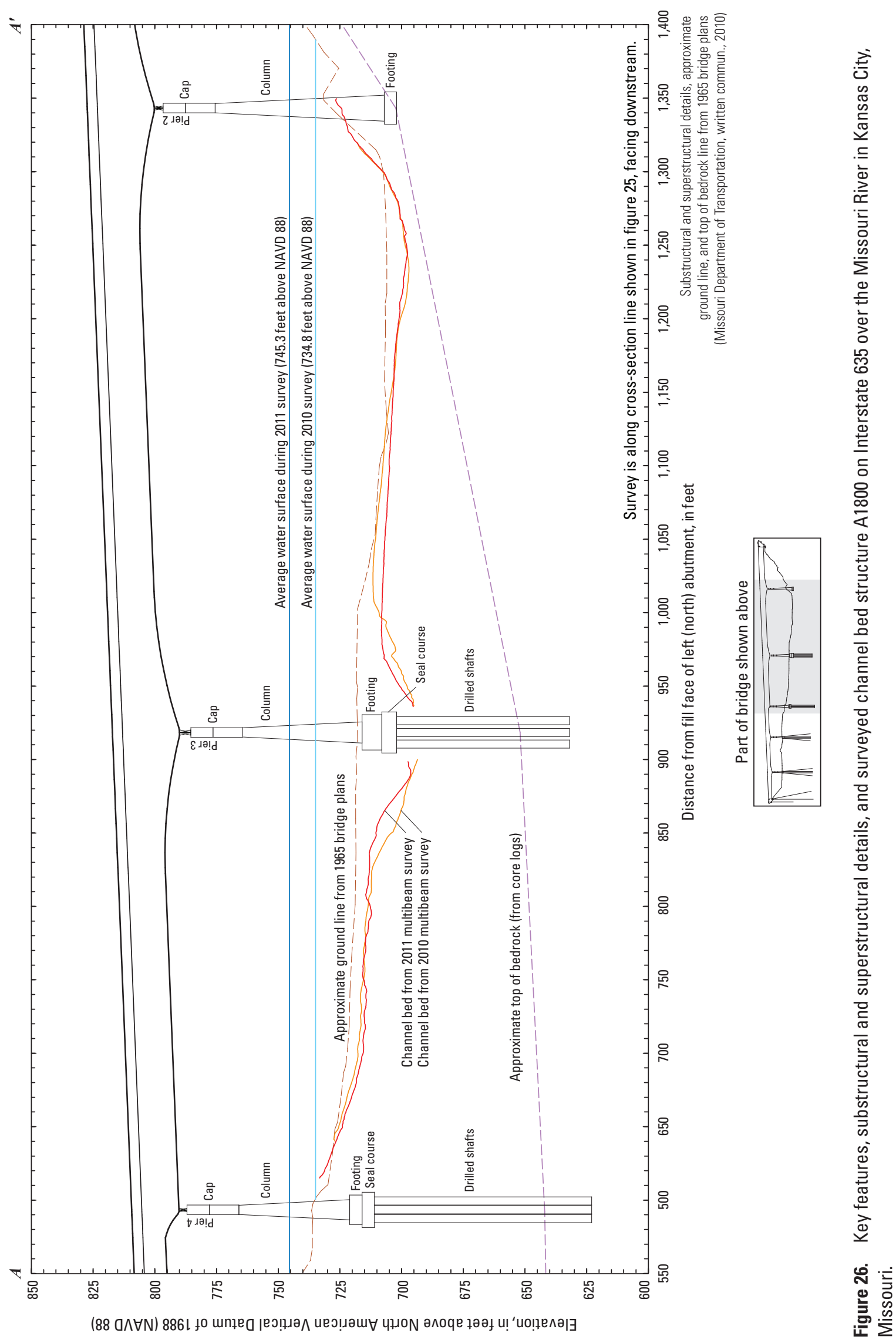




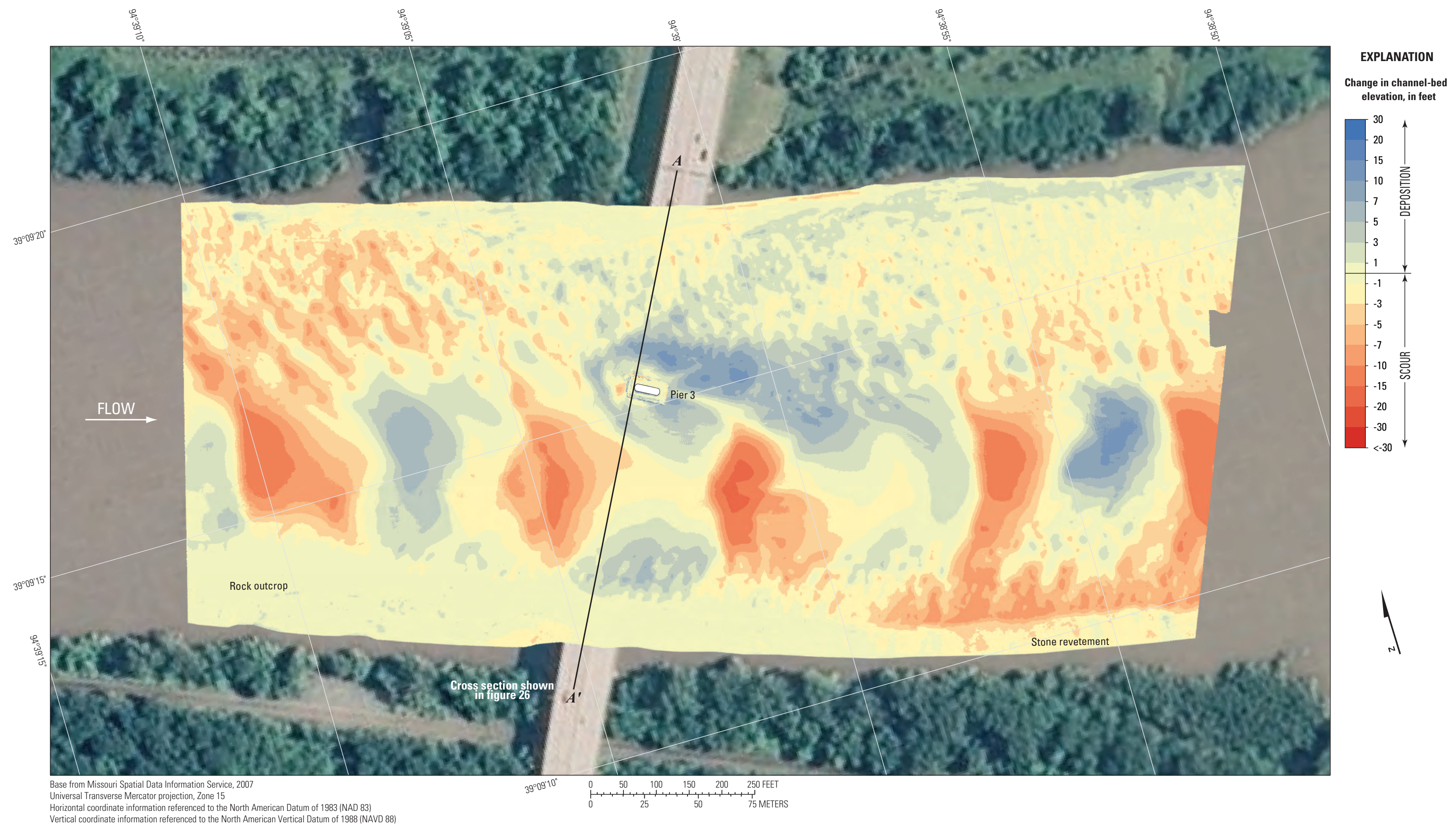

Figure 27. Difference between surfaces created from bathymetric surveys of the Missouri River channel in the vicinity of structure A1800 on Interstate 635 in Kansas City, Missouri, on March 15, 2010, and July 16, 2011. 


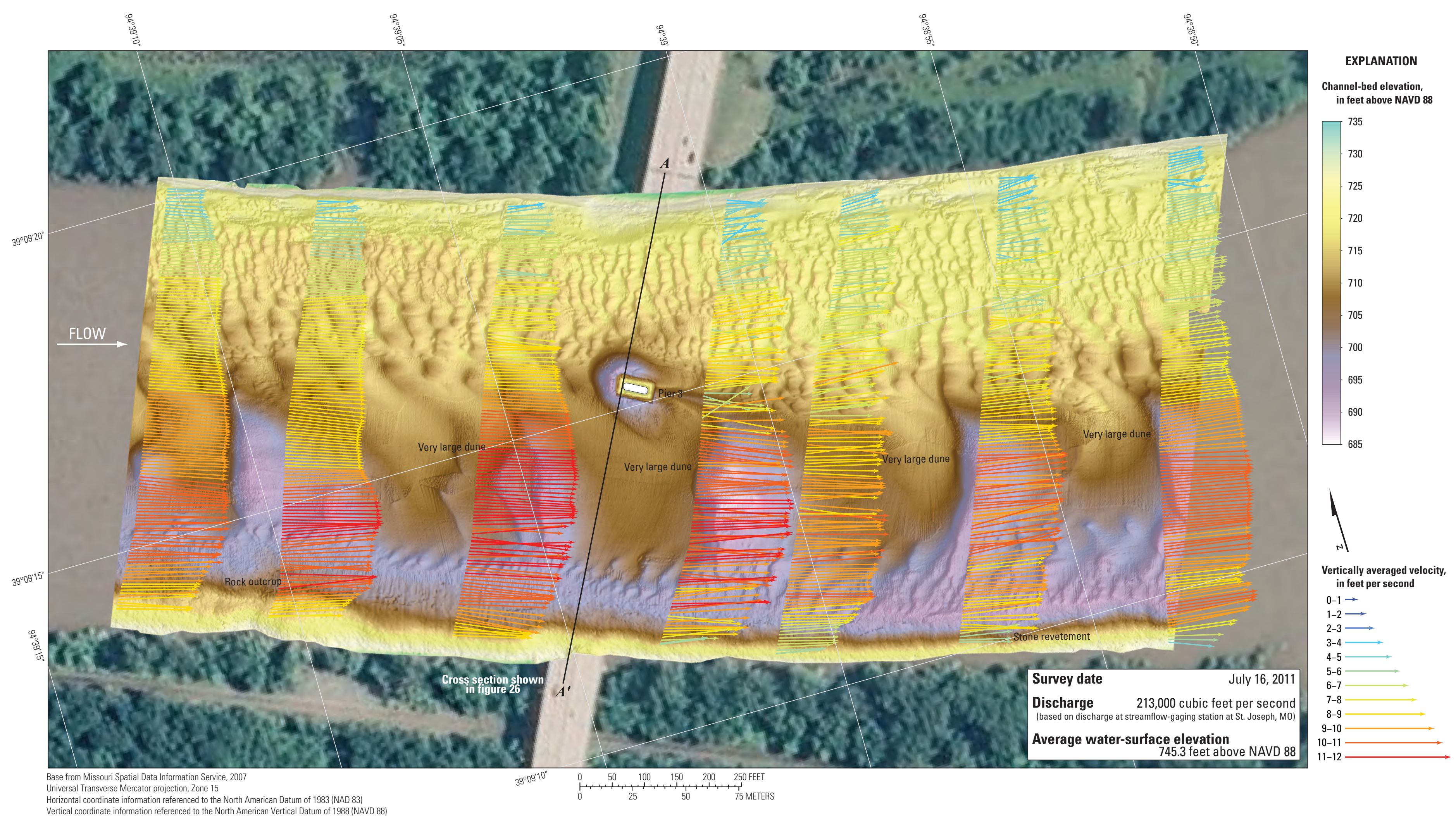

Figure 28. Bathymetry and vertically averaged velocities of the Missouri River channel in the vicinity of structure A1800 on Interstate 635 in Kansas City, Missouri. 


\section{Structures K0456 and A0450 on U.S. Highway 69 in Kansas City, Missouri}

Structures K0456 and A0450 (site 7) are dual bridges on U.S. Highway 69, crossing the Missouri River at RM 372.6 on the northwestern side of Kansas City, Missouri (fig. 1). The site was surveyed on July 16, 2011; the average watersurface elevation of the river in the survey area, determined by the RTK GPS tide solution, was $743.9 \mathrm{ft}$ (table 5). Flow on the Missouri River was about 213,000 $\mathrm{ft}^{3} / \mathrm{s}$ during the survey, according to the streamgage at St. Joseph, Missouri (table 5).

The survey area was about 1,640 ft long and about $790 \mathrm{ft}$ wide, extending from bank to bank in the main channel (fig. 29). The upstream end of the survey area was about $755 \mathrm{ft}$ upstream from the centerline between structures K0456 and A0450 (fig. 29). The channel-bed elevations ranged from about 695 to $722 \mathrm{ft}$ for most of the surveyed area (5 to 95 percentile range of the bathymetric data; fig. 29). A narrow thalweg along the outside of the channel bend on the right (south) bank ranged from 8 to $20 \mathrm{ft}$ deeper than the channel bed on the inside of the bend on the left (north) bank (fig. 29). One large dune feature was detected in the middle of the upstream channel; otherwise, the channel bed was smooth with numerous smaller dunes and ripples along the banks (fig 29). Because the channel bed was smooth, minor variations in the sonar head (believed to be caused by pole flexure) were exacerbated, resulting in discrepancies between the swathes that appear as longitudinal stripes in the survey (fig. 29). Stone revetment was present on the right (south) bank throughout the reach (fig. 29).

In the vicinity of main channel pier 7 of upstream structure K0456 (fig. 29), a scour hole had a minimum channelbed elevation of about $677 \mathrm{ft}$ (table 6), about $32 \mathrm{ft}$ below the average channel bed immediately upstream from the pier. The scour hole upstream from pier 7 of upstream structure K0456 was about $8 \mathrm{ft}$ deeper than the scour hole upstream from pier 9 of downstream structure A0450 (table 6). Information from bridge plans indicates that the main channel piers of both structures K0456 and A0450 are caissons on bedrock (figs. 30, 31). About $50 \mathrm{ft}$ of bed material was between the bottom of the deeper scour hole at structure K0456 and the bottom of the caissons (fig. 30; table 6).

The difference between the survey on July 16, 2011, and the previous survey on March 15, 2010 (fig. 32) indicates substantial deposition from 2010 to 2011, particularly downstream from the upstream spur dike. The average difference between the bathymetric surfaces was $+2.45 \mathrm{ft}$ (table 7). However, there was substantial scour downstream from the downstream spur dike (fig. 32), and there appeared to be an area of net scour on the left (north) side and the thalweg in the downstream reach, with an area of net deposition between them (fig. 32). The cross sections along the upstream bridge faces from the two surveys are similar to one another in shape with the 2011 survey generally higher than the 2010 survey (figs. 30, 31), despite a water-surface elevation difference of more than $10 \mathrm{ft}$ and a flow difference of 84,000 ft³ $3 / \mathrm{s}$ (table 7). As was observed at structure A1800 upstream, the scour holes near the main channel piers were narrower in 2011 than in 2010 (figs. 30, 31), as evidenced by the overall pattern of deposition in a horseshoe shape around the piers (fig. 32). The stone revetment on the right (south) bank appeared to have experienced a mix of scour and deposition (fig. 32).

The vertically averaged velocity vectors indicate mostly uniform flow upstream from the bridge, with a maximum of $12 \mathrm{ft} / \mathrm{s}$ in the middle of the channel decreasing to about $4 \mathrm{ft} / \mathrm{s}$ along the banks (fig. 33). Velocities were higher in the center of the channel than in the thalweg, likely because flow was uniform and shallower in the center. Minor turbulence was observed in the downstream vicinity of the main channel piers and along the right (south) bank (fig. 33).

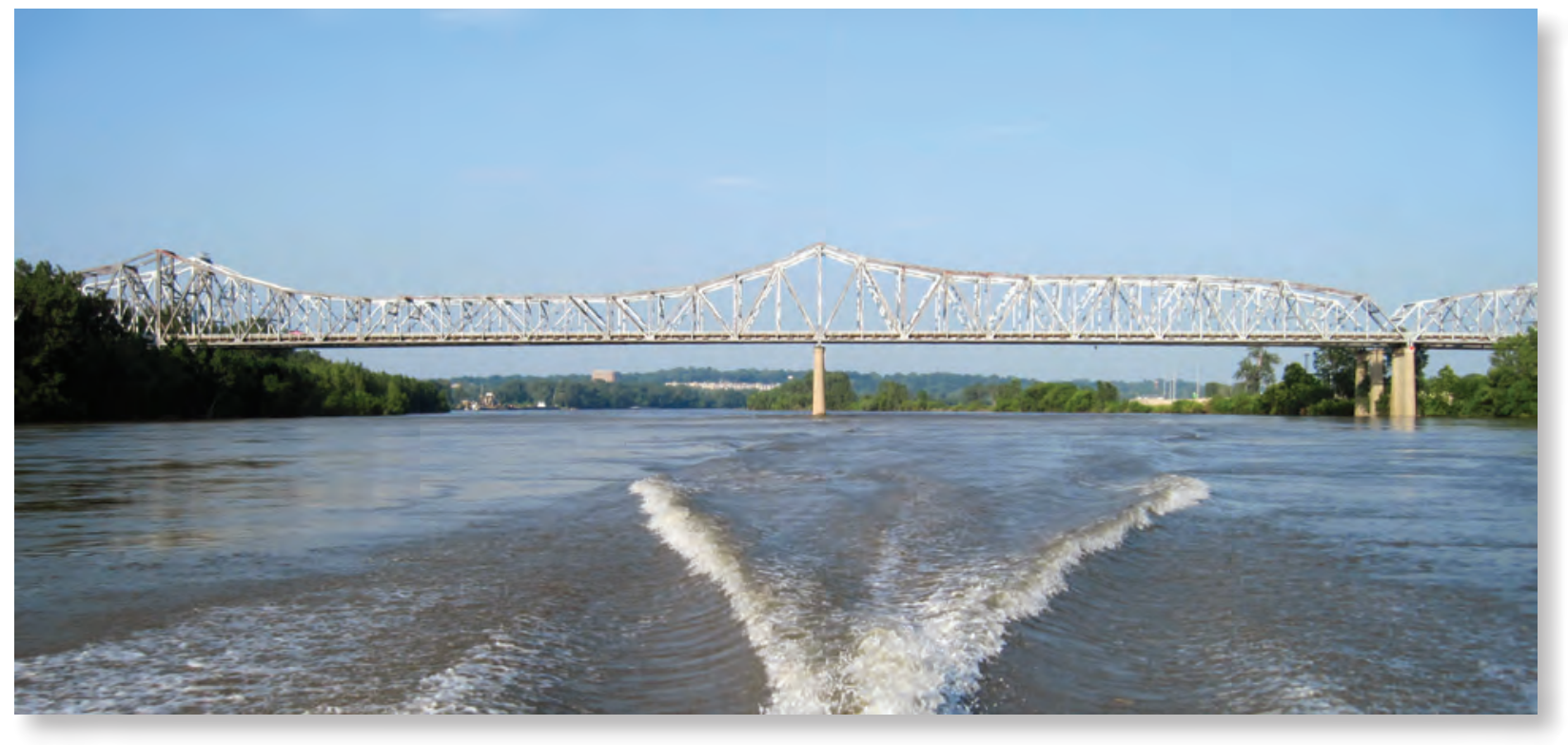

Structures K0456 and A0450 on U.S. Highway 69 in Kansas City, Missouri. Structure K0456 is in the foreground and $\mathrm{A} 0450$ is in the background. 


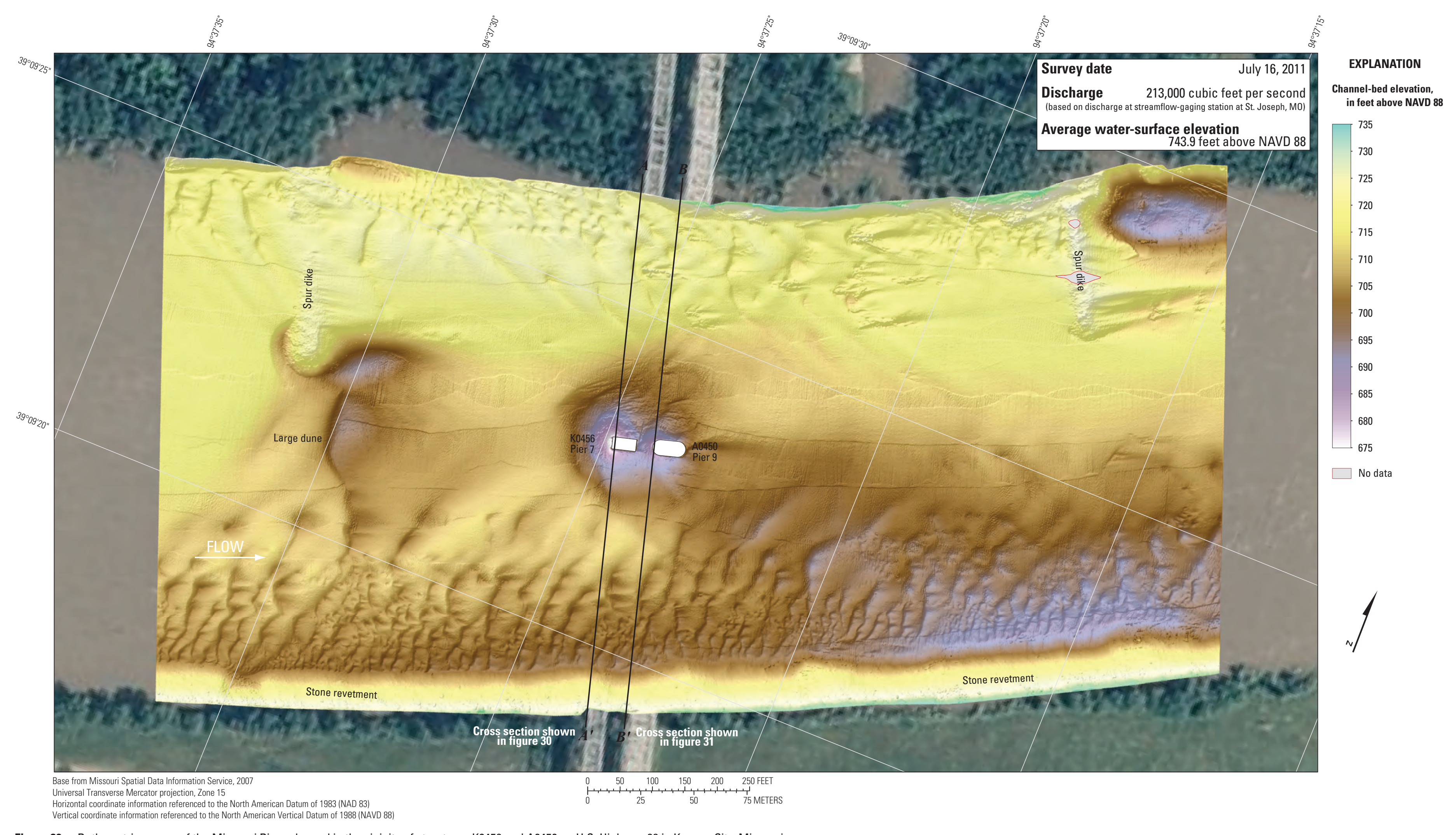

Figure 29. Bathymetric survey of the Missouri River channel in the vicinity of structures K0456 and A0450 on U.S. Highway 69 in Kansas City, Missouri. 


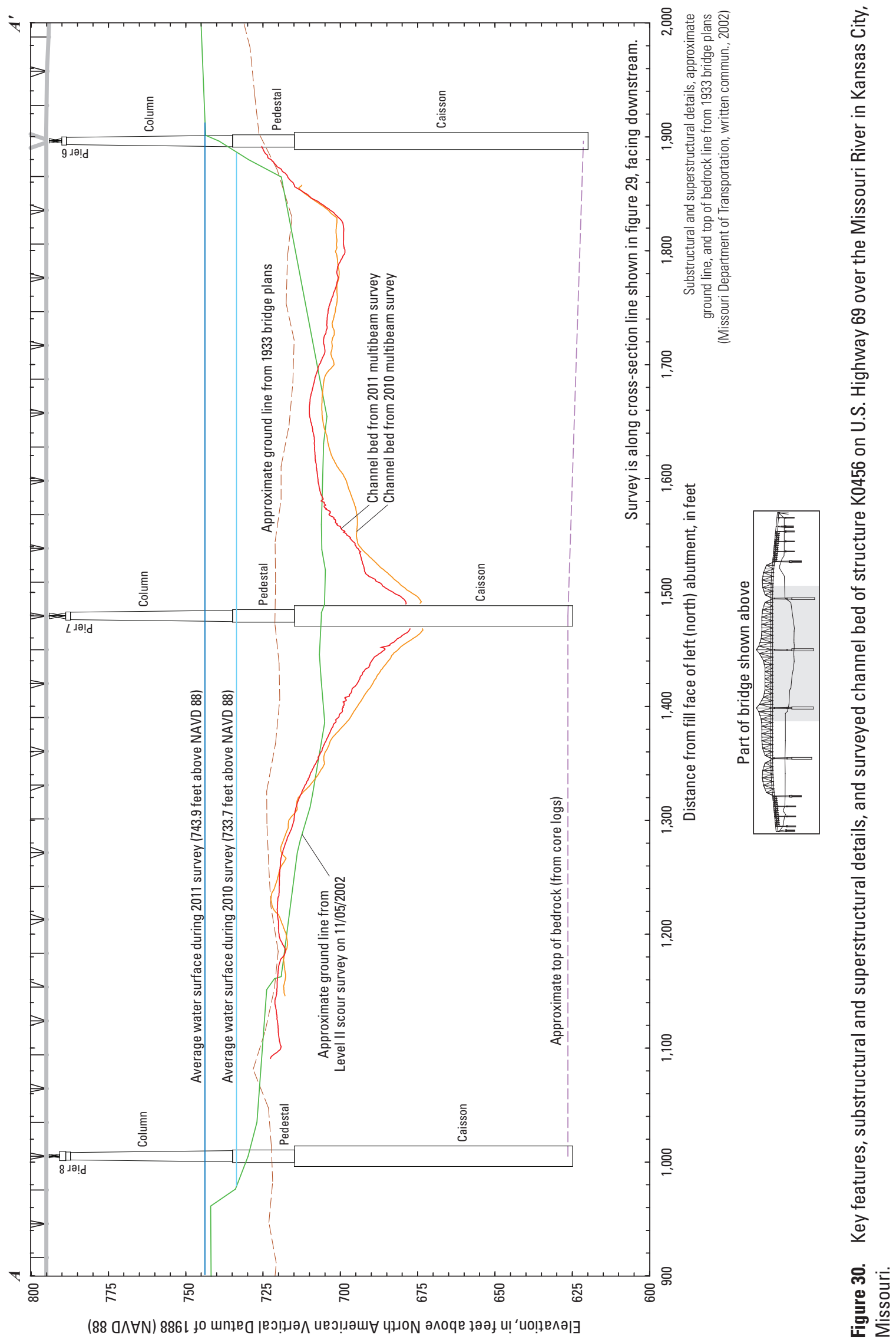




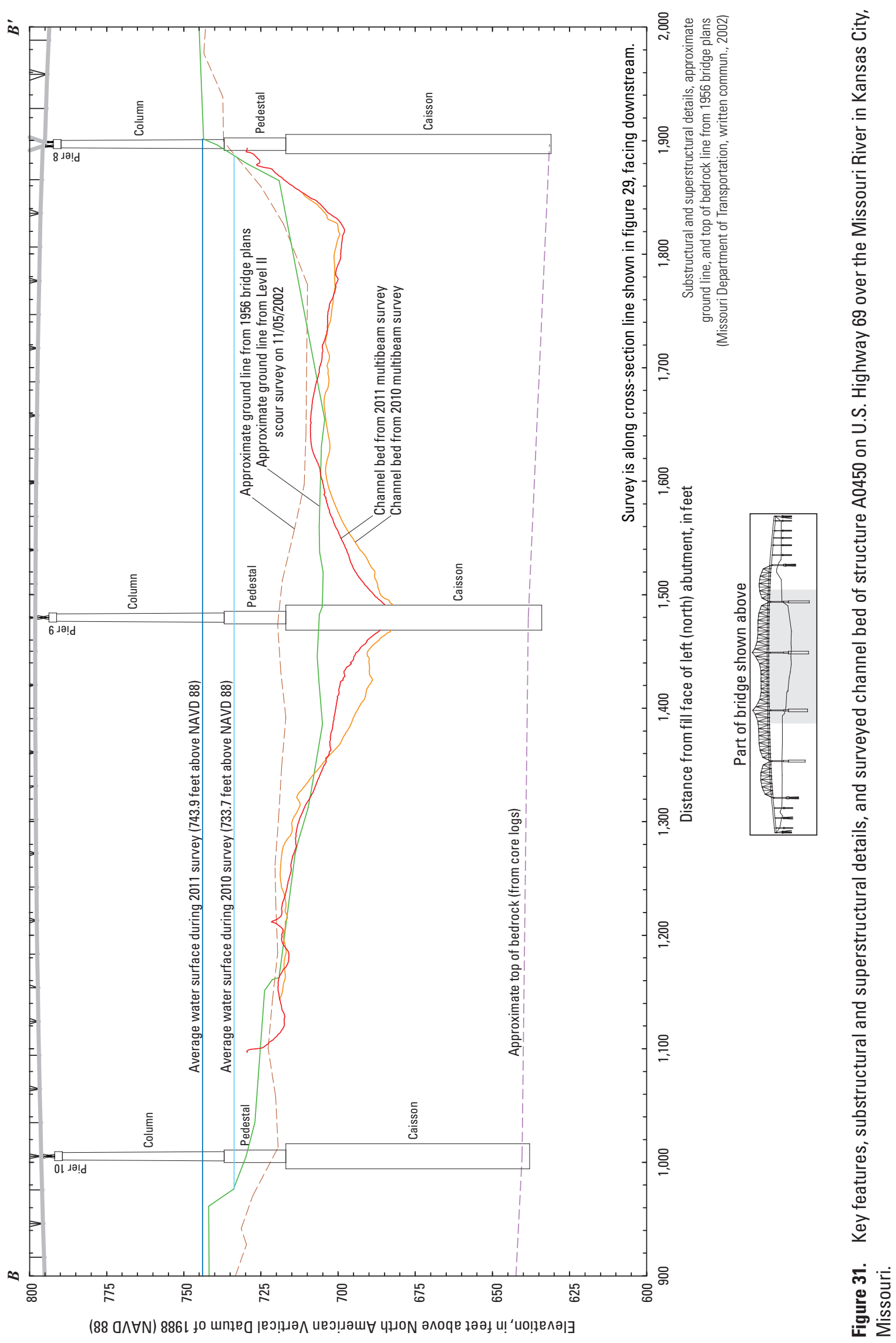




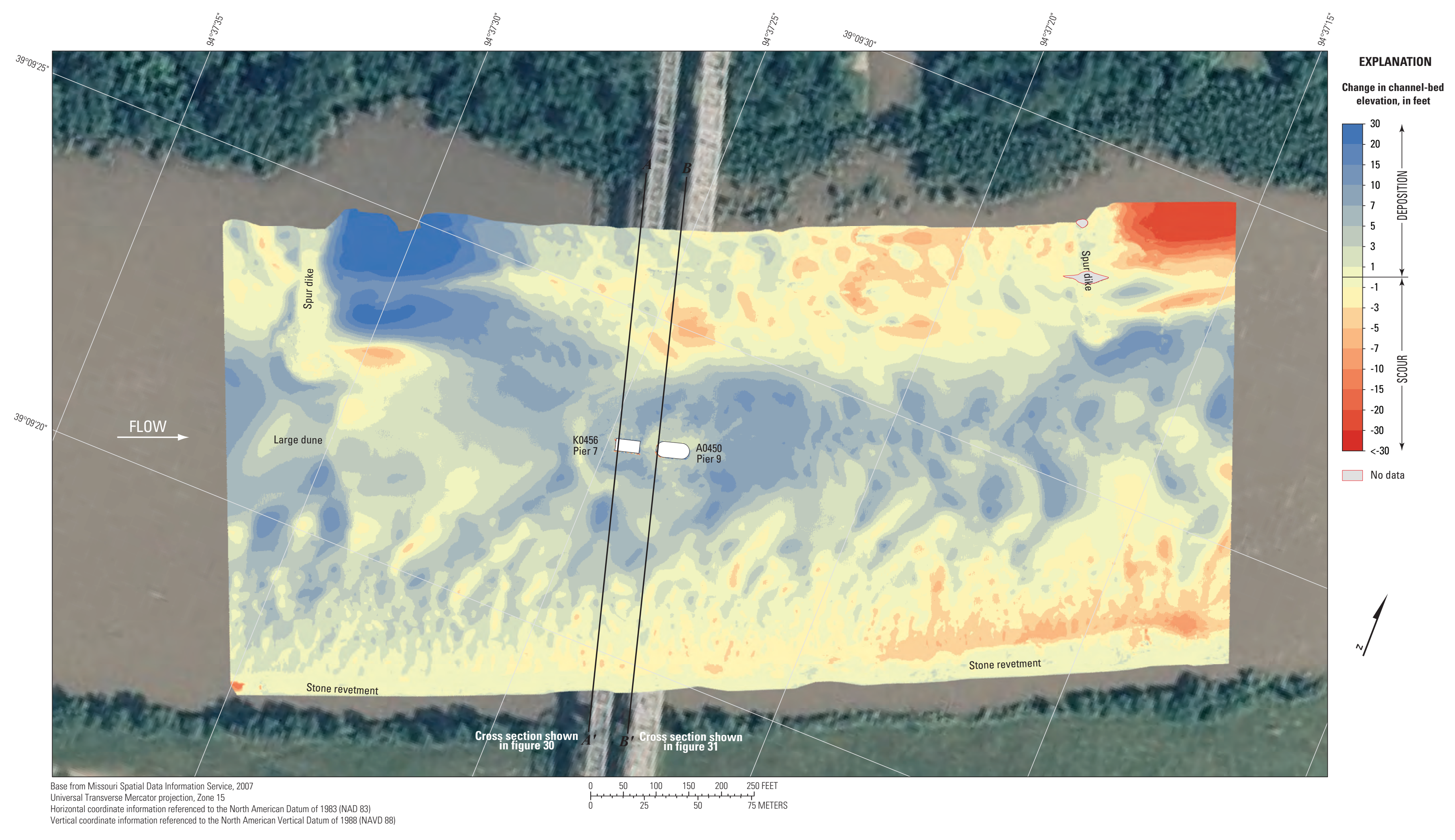

Figure 32. Difference between surfaces created from bathymetric surveys of the Missouri River channel in the vicinity of structures K0456 and A0450 on U.S. Highway 69 in Kansas City, Missouri, on March 15, 2010 , and July 16, 2011. 


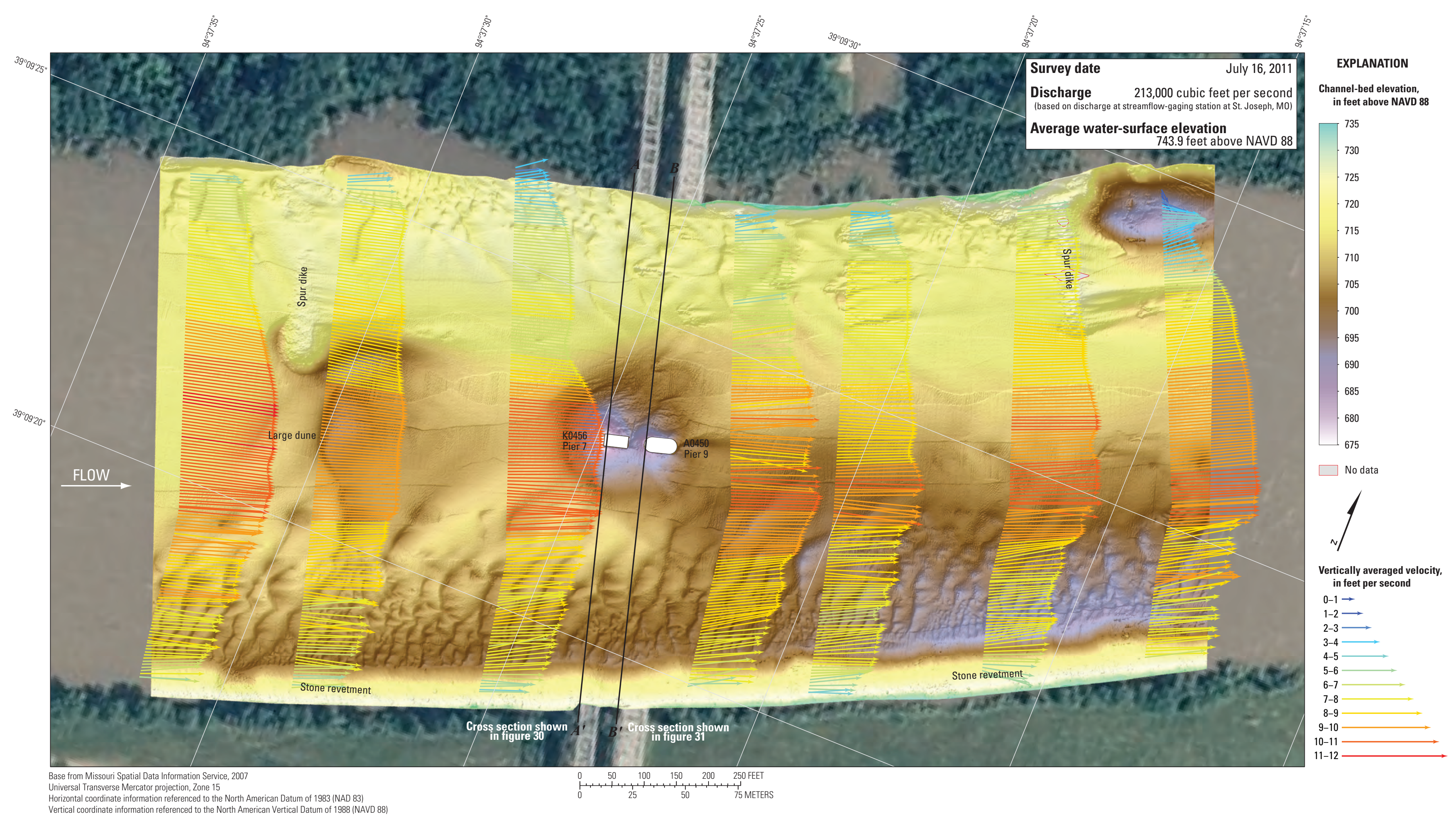

Figure 33. Bathymetry and vertically averaged velocities of the Missouri River channel in the vicinity of structures K0456 and A0450 on U.S. Highway 69 in Kansas City, Missouri. 


\section{Structure A4649 on U.S. Highway 169 in Kansas City, Missouri}

Structure A4649 (site 8) on U.S. Highway 169 crosses the Missouri River at RM 366.2, immediately north of downtown Kansas City, Missouri (fig. 1). The site was surveyed on July 17,2011 , and the average water-surface elevation of the river in the survey area, determined by the RTK GPS tide solution, was $737.6 \mathrm{ft}$ (table 5). Flow on the Missouri River was about $217,000 \mathrm{ft}^{3} / \mathrm{s}$ during the survey, according to the streamgage at Kansas City, Missouri (table 5).

The survey area was about 1,660 ft long and about $885 \mathrm{ft}$ wide, extending from bank to bank in the main channel (fig. 34). The upstream end of the survey area was about $720 \mathrm{ft}$ upstream from the centerline of structure A4649 at pier 2 (fig. 34). The channel-bed elevations ranged from about 692 to $722 \mathrm{ft}$ for most of the surveyed area (5 to 95 percentile range of the bathymetric data), except near pier 2 of structure A4649, the various railroad bridge piers, and the concrete nose upstream from the railroad bridge turntable pier (fig. 34). A deep thalweg on the right (south) bank on the upstream end of the surveyed area was about $25 \mathrm{ft}$ deeper than the channel bed in the middle of the channel (fig. 34). The thalweg became shallower and shifted to the left at the bridges and downstream (fig. 34). Remnants of piers from an old bridge were evident downstream from the existing railroad bridge (fig. 34). One large dune feature was detected in the upstream channel at this site, and numerous medium and small dunes and ripples were detected throughout the channel, particularly in the channel thalweg upstream from structure A4649 and downstream from the railroad bridge (fig. 34). The various bed features were dynamic between survey passes, and there likely were minor variations in the sonar mount (caused by pole flexure), resulting in discrepancies between the swathes that appear as longitudinal stripes in the survey (fig. 34). The shallow area in the upstream left part of the channel was not extensively surveyed because of the increased risk of damage to the sonar head and the inordinate time required to adequately survey the area, resulting in several long patches of no data between swathes in this area (fig. 34). Stone revetment was present on the right (south) bank throughout the reach (fig. 34).

In the vicinity of main channel pier 2 (fig. 34), a scour hole had a minimum channel-bed elevation of about $687 \mathrm{ft}$ (table 6), about $22 \mathrm{ft}$ below the average channel bed immediately upstream from the pier (table 6). The scour hole extended further around the right side of the pier, with a submerged remnant of a structure near the left downstream side of the pier (fig. 34), presumably a nose for the railroad bridge downstream similar to the concrete nose upstream from the railroad bridge turntable pier. As in the previous survey at this site (Huizinga, 2010), the remnants of the old bridge piers were clearly defined, as were the piles of particulate rock debris around them. The remnant downstream from the existing railroad bridge turntable pier had a maximum elevation greater than $710 \mathrm{ft}$, which is about $13 \mathrm{ft}$ above the channel bed immediately upstream from it. Avoiding this pier remnant would be difficult in lower flow conditions than those on the day of the survey. The overall minimum channel-bed elevation was $678.5 \mathrm{ft}$, and occurred upstream from the left railroad bridge pier. Information from bridge plans indicate that main channel pier 2 of structure A4649 is a caisson on bedrock, with about $17 \mathrm{ft}$ of bed material between the bottom of the scour hole and the bottom of the caissons (fig. 35; table 6).

The difference between the survey on July 17, 2011, and the previous survey on March 16, 2010 (fig. 36) indicates substantial deposition throughout the reach from the 2010 to 2011 surveys, with an average difference of $+4.68 \mathrm{ft}$ between the bathymetric surfaces (table 7). There was one area of substantial scour downstream from the large dune feature in the 2011 survey, and about 3 to $5 \mathrm{ft}$ of scour along the bottom of the right (south) bank (fig. 36). The cross sections from the two surveys also were substantially different from one another (fig. 35), with the 2011 section 10 to $15 \mathrm{ft}$ higher than in 2010, despite a water-surface elevation difference of nearly $10 \mathrm{ft}$ and a flow difference of $90,000 \mathrm{ft}^{3} / \mathrm{s}$ (table 7). The scour hole near main channel pier 2 in 2011 was of a similar shape to that in 2010, albeit much shallower (figs. 35, 36); however, near the railroad bridge piers and concrete nose, the scour holes are approximately the same between the two surveys (fig. 36). As with several difference maps earlier in this report, the appearance of substantial deposition or scour at the faces of the piers result from minor horizontal positional variances between the surveys.

The vertically averaged velocity vectors indicate mostly uniform flow upstream from the structure A4649 ranging from about 4 to $11 \mathrm{ft} / \mathrm{s}$ (fig. 37). Flow appeared to be diagonal across the channel immediately upstream of structure A4649 (fig. 37). Substantial turbulence was observed between structure A4649 and the railroad bridge and in the downstream part of the reach at this site (fig. 37).

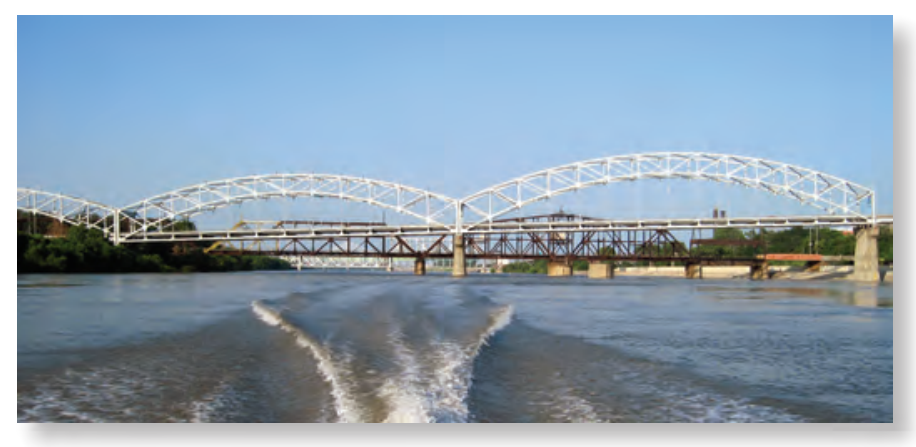

Structure A4649 on U.S. Highway 169 in Kansas City, Missouri. The second Hannibal railroad bridge is in the immediate background. 


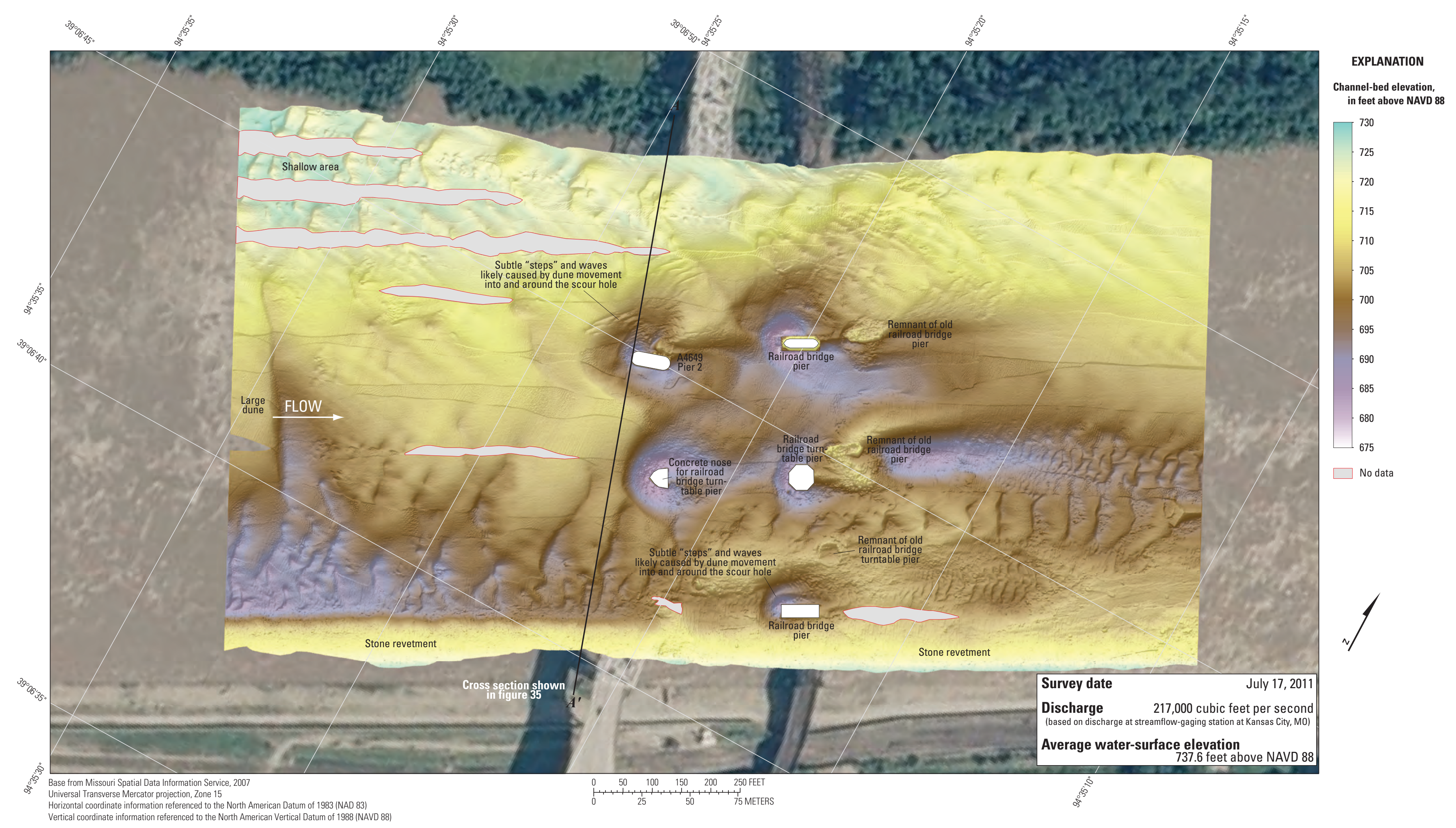

Figure 34. Bathymetric survey of the Missouri River channel in the vicinity of structure A4649 on U.S. Highway 169 in Kansas City, Missouri. 


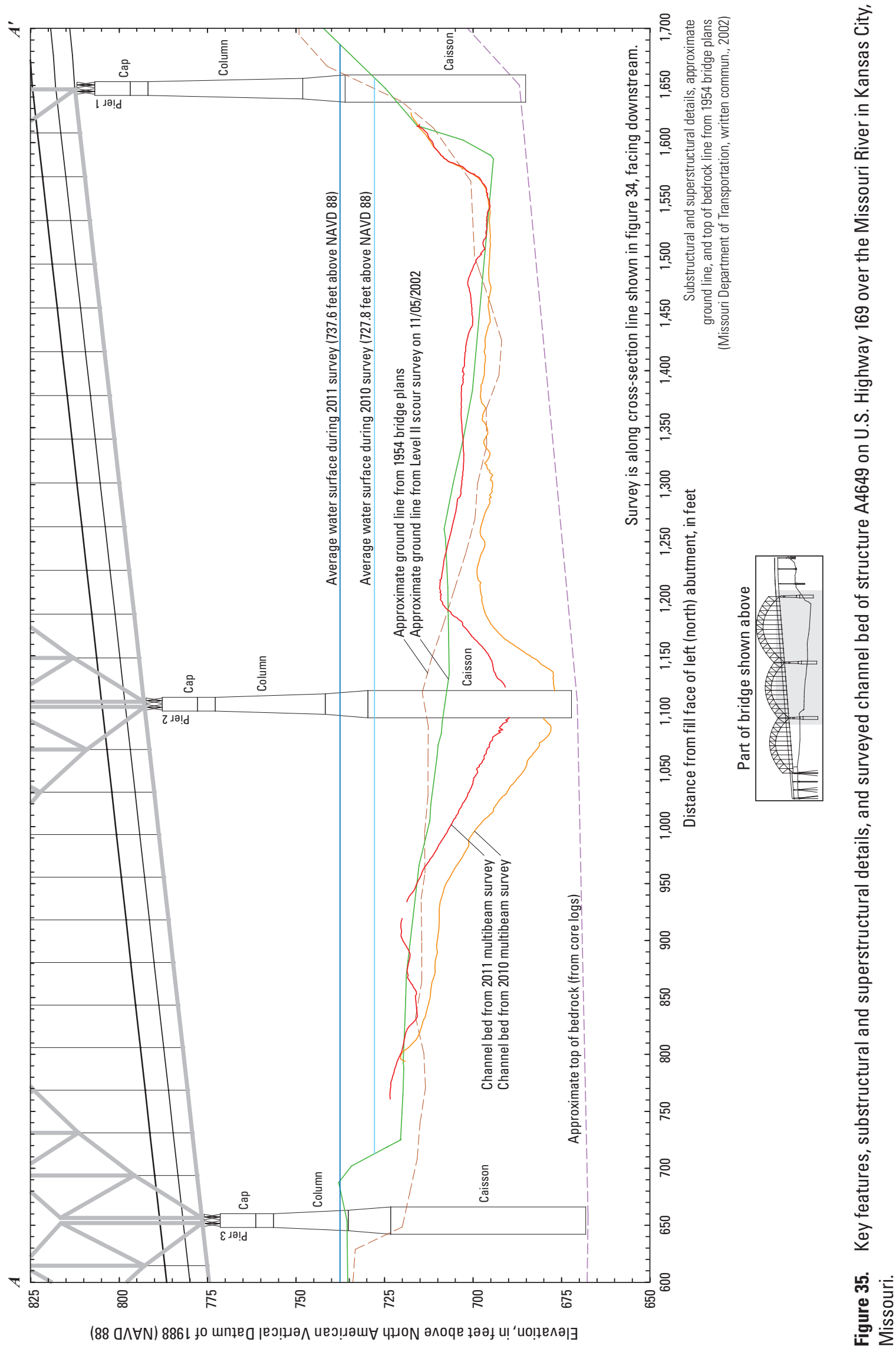




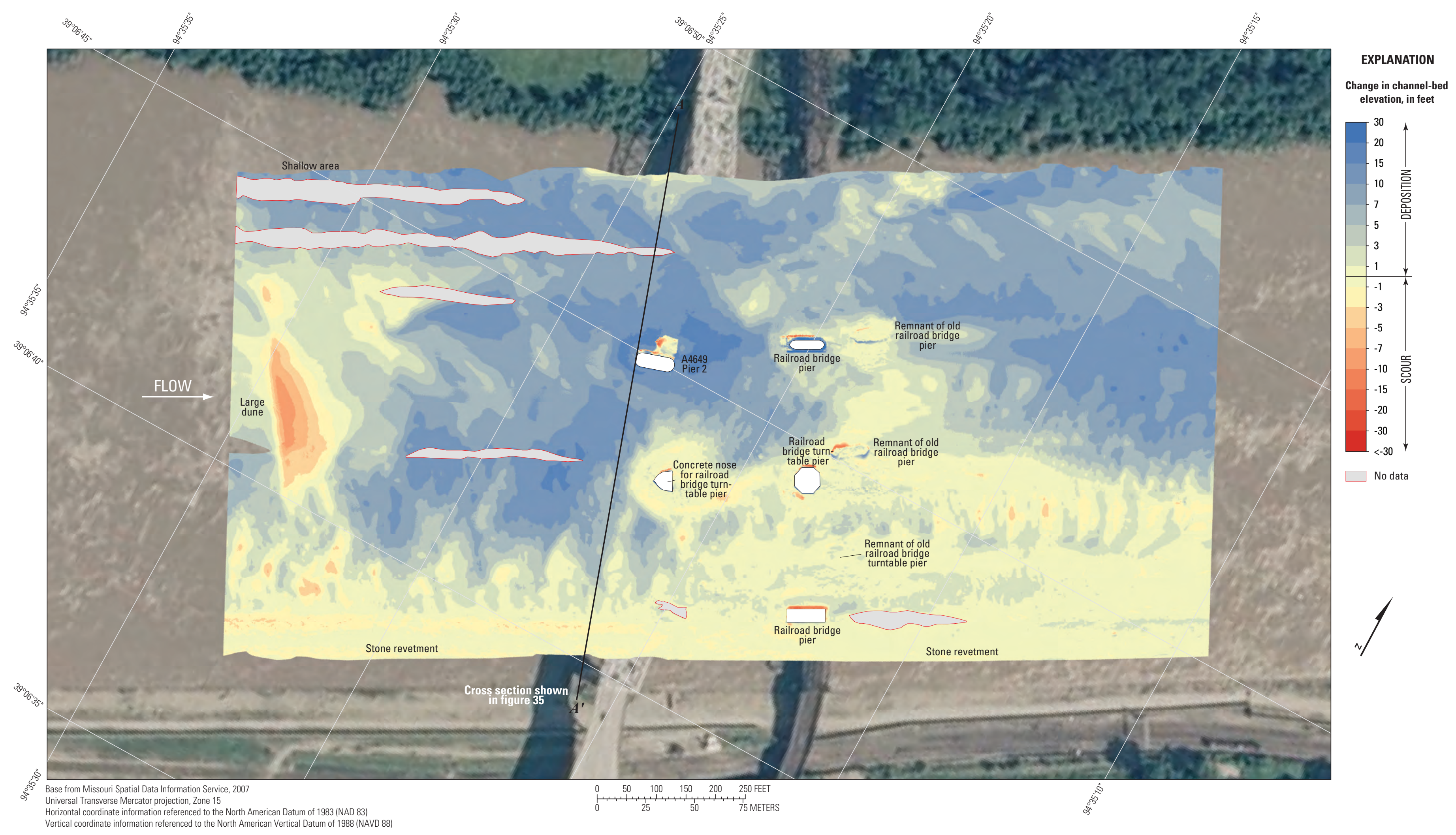

Figure 36. Difference between surfaces created from bathymetric surveys of the Missouri River channel in the vicinity of structure A4649 on U.S. Highway 169 in Kansas City, Missouri, on March 16, 2010 , and July 17, 2011. 


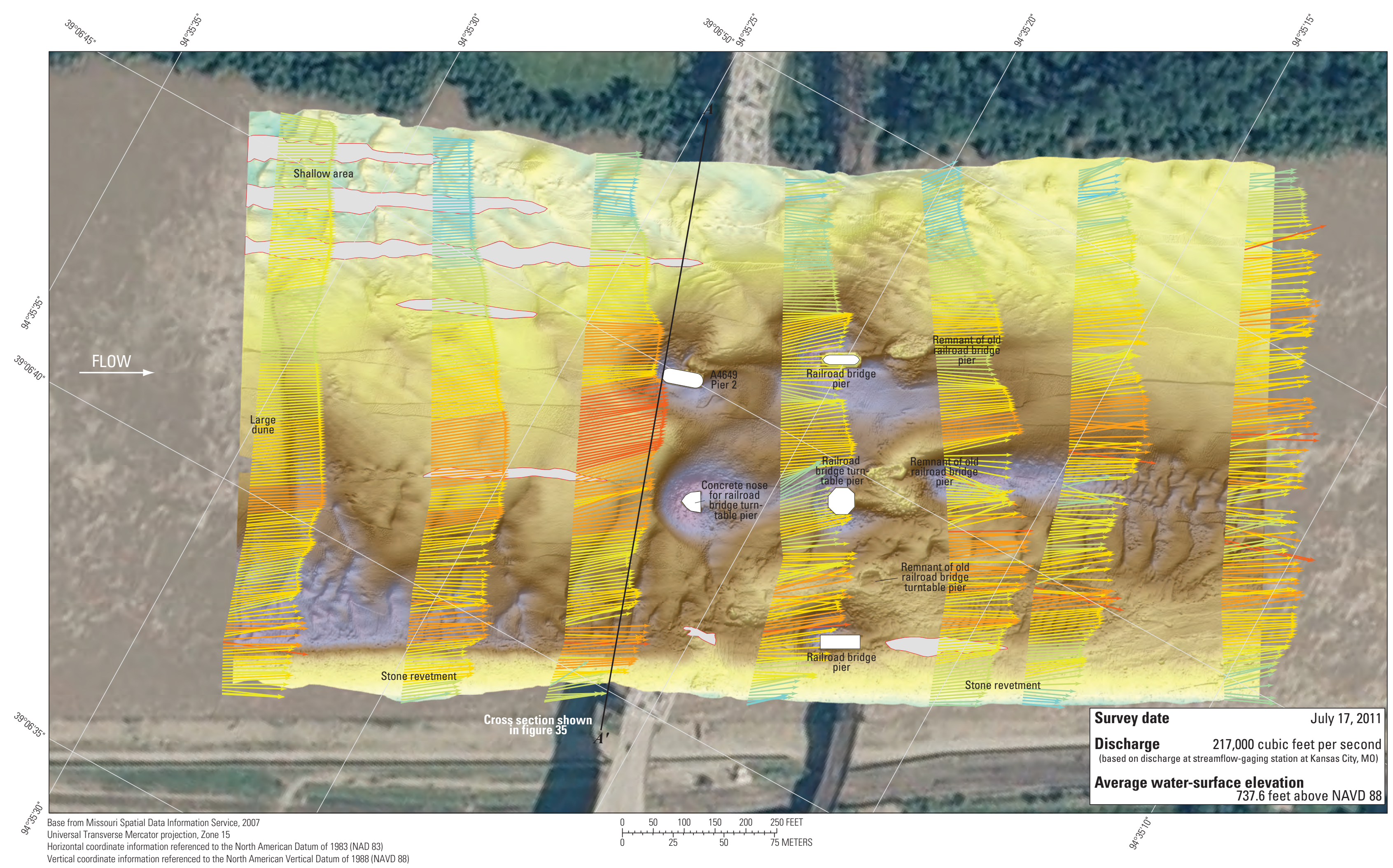

EXPLANATION

Channel-bed elevation,

730

.725

Figure 37. Bathymetry and vertically averaged velocities of the Missouri River channel in the vicinity of structure A4649 on U.S. Highway 169 in Kansas City, Missouri. 


\section{Structure A4060 on State Highway 9 in Kansas City, Missouri}

Structure A4060 (site 9) on State Highway 9 crosses the Missouri River at RM 365.5, immediately north of downtown Kansas City, Missouri (fig. 1), and approximately 3,400 ft downstream from structure A4649 on U.S. Highway 169. The site was surveyed on July 17, 2011, and the average watersurface elevation of the river in the survey area, determined by the RTK GPS tide solution, was $737.1 \mathrm{ft}$ (table 5). Flow on the Missouri River was about 217,000 $\mathrm{ft}^{3} / \mathrm{s}$ during the survey, according to the streamgage at Kansas City, Missouri (table 5).

The survey area was about 1,640 ft long and about $850 \mathrm{ft}$ wide, extending from bank to bank in the main channel (fig. 38). Piers 5 and 6 were in the water and away from the banks, and the upstream end of the survey area was about $665 \mathrm{ft}$ upstream from the centerline of structure A4060 at pier 6 (fig. 38). The channel-bed elevations ranged from about 693 to $713 \mathrm{ft}$ for most of the surveyed area ( 5 to 95 percentile range of the bathymetric data), except near the railroad bridge pier upstream from pier 6 of structure A4060 (fig. 38). A thalweg along the right (south) bank throughout the surveyed area was about $15 \mathrm{ft}$ deeper than the channel bed in the middle of the channel (fig. 38). A few medium dune features were detected in the middle of the channel upstream from the bridges, and numerous smaller dunes and ripples were present along the channel thalweg on the right (south) side (fig. 38). Downstream from structure A4060, the elevations in the middle of the channel were 4 to $7 \mathrm{ft}$ lower than elevations upstream from the bridges (fig. 38). Stone revetment was present on the right (south) bank throughout the reach (fig. 38).

In the immediate vicinity of left (north) main channel pier 5 (fig. 38), a scour hole had a minimum channel-bed elevation of about $689 \mathrm{ft}$ (table 6), about $7 \mathrm{ft}$ below the elevation of the bottom of the pier seal course of $696.26 \mathrm{ft}$ (fig. 39; table 6). Several beams or piles were protruding from the channel bed immediately upstream from pier 5 (fig. 38). Near the right (south) main channel pier 6 (fig. 38), a poorly defined scour hole had a minimum channel-bed elevation of about $686 \mathrm{ft}$; however, a substantial scour hole immediately upstream from the pier had a minimum channel-bed elevation of about $676 \mathrm{ft}$. This deeper hole likely was the result of flow over large sheet piling panels that were lying on the channel bottom on the right (south) side of the upstream railroad bridge pier (fig. 38) observed in the previous survey (Huizinga, 2010). A pile of particulate rock material immediately upstream from pier 6 of structure A4060 extended around the right (south) side (fig. 38 ), but the highest point on this pile was about $1 \mathrm{ft}$ below the elevation of the bottom of the pier seal course of $696.26 \mathrm{ft}$ (fig. 38; table 6). The minimum channel-bed elevation in the vicinity of pier 6 was about $10 \mathrm{ft}$ below the elevation of the bottom of the pier seal course (fig. 38; table 6). Information from bridge plans indicates that piers 5 and 6 are founded on shafts drilled $20 \mathrm{ft}$ into bedrock, with about $22 \mathrm{ft}$ of bed material between the bottom of the scour hole and bedrock at pier 5 and $16 \mathrm{ft}$ of material at pier 6 (fig. 39; table 6).

The difference between the survey on July 17, 2011, and the previous survey on March 16, 2010 (fig. 40) indicates substantial deposition throughout the reach from 2010 to 2011, with an average difference of $+2.03 \mathrm{ft}$ between the bathymetric surfaces (table 7). There were a few areas of substantial scour: one along the left bank downstream from the left (north) railroad bridge pier, one at the downstream end of the reach, and one upstream from the right (south) railroad bridge pier (fig. 40). There also were a few areas of minor scour among the medium and small dunes and ripples in the thalweg (fig. 40). The cross sections from the two surveys were similar to one another in the thalweg on the right side of the channel (fig. 39), despite a water-surface elevation difference of more than $10 \mathrm{ft}$ and a flow difference of 91,000 ft $3 / \mathrm{s}$ (table 7); however, the sections were substantially different from one another in the left part of the channel (fig. 39). The scour hole near main channel pier 5 in 2011 was of a similar shape to that in 2010, albeit shallower on one side and deeper on the other (figs. 39, 40). As with several difference maps earlier in this report, the appearance of substantial deposition or scour at the faces of the piers result from minor horizontal positional variances between the surveys. The stone revetment on the right (south) bank appeared to have several areas of localized scour (fig. 40).

The vertically averaged velocity vectors indicate mostly uniform flow in the shallow part of the channel on the left (north) side, ranging from about 6 to $11 \mathrm{ft} / \mathrm{s}$ (fig. 41). In the deeper thalweg, flow was slightly slower and more turbulent (fig. 41). Substantial turbulence was observed between the right (south) piers of the railroad bridge and structure A4060 (fig. 41).

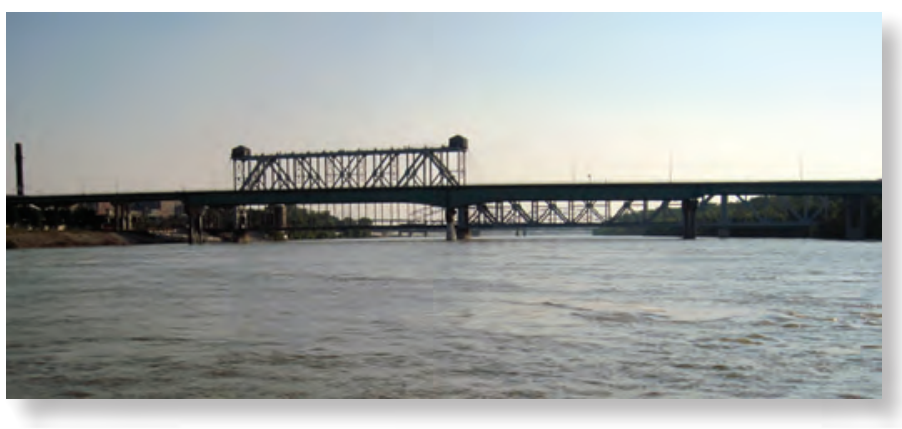

Structure A4060 on State Highway 9 in Kansas City, Missouri. The Armour-Swift-Burlington railroad bridge is in the immediate background. 


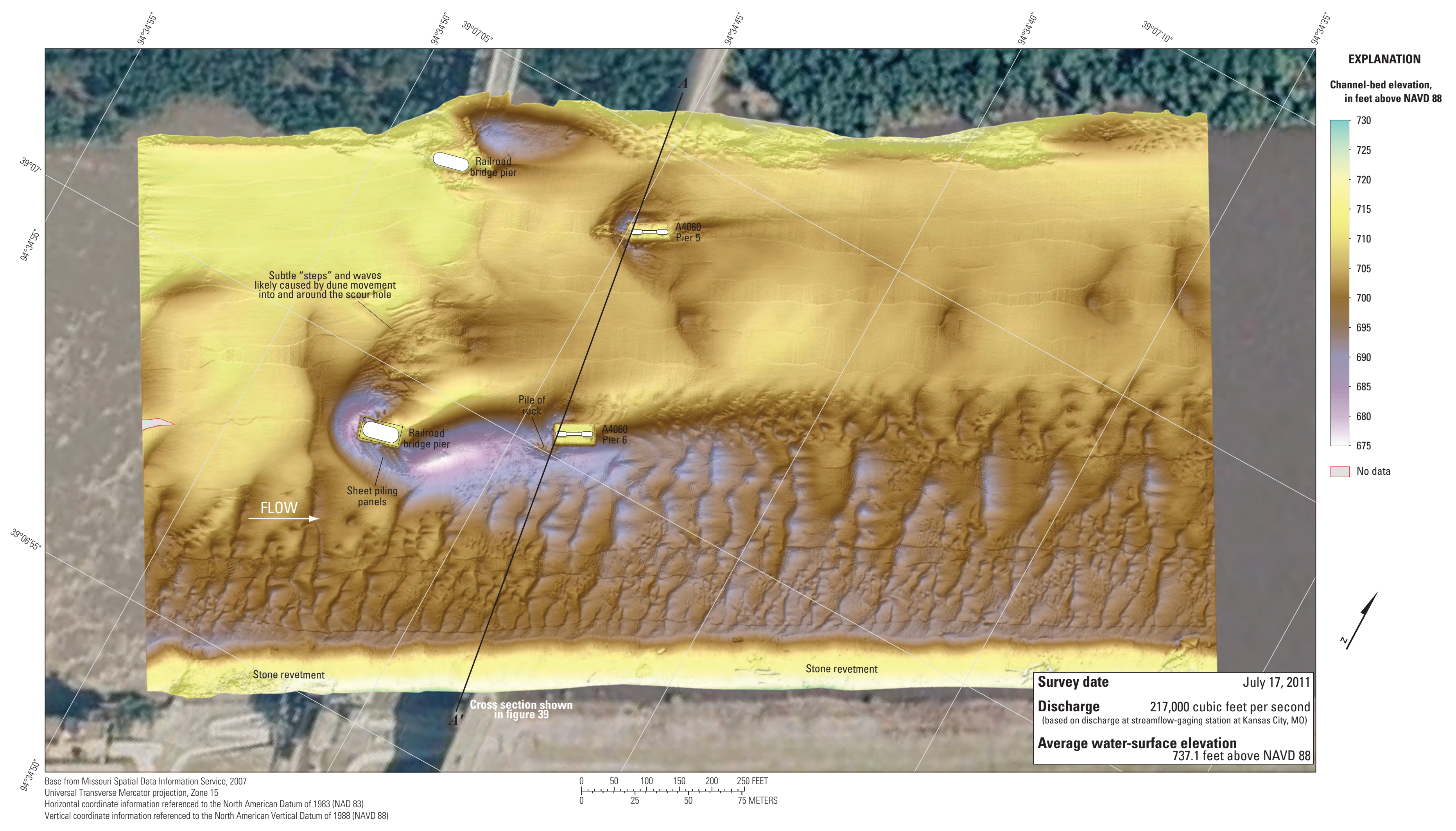

Figure 38. Bathymetric survey of the Missouri River channel in the vicinity of structure A4060 on State Highway 9 in Kansas City, Missouri. 


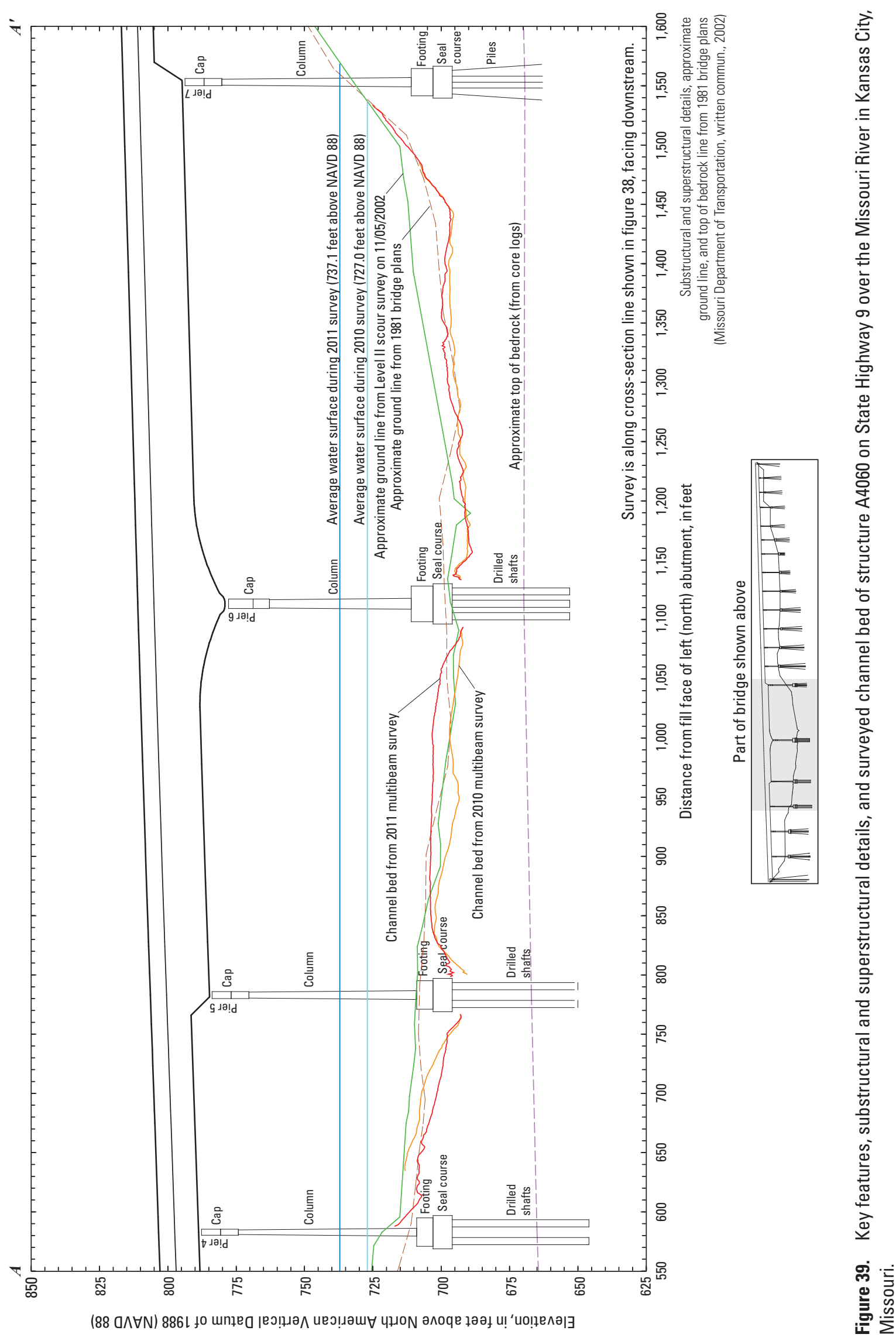




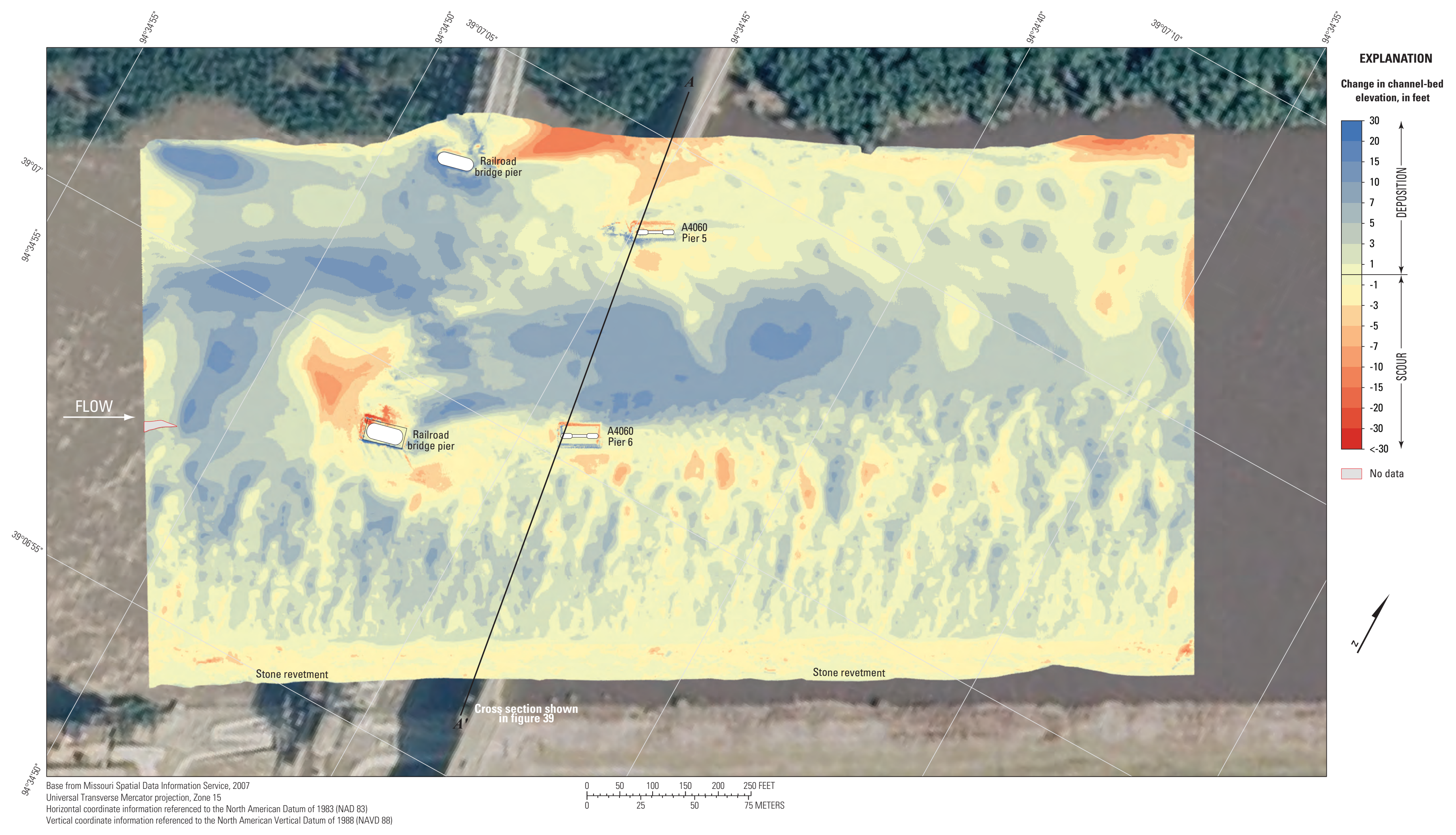

Figure 40. Difference between surfaces created from bathymetric surveys of the Missouri River channel in the vicinity of structure A4060 on State Highway 9 in Kansas City, Missouri, on March 16, 2010 , and July 17, 2011. 


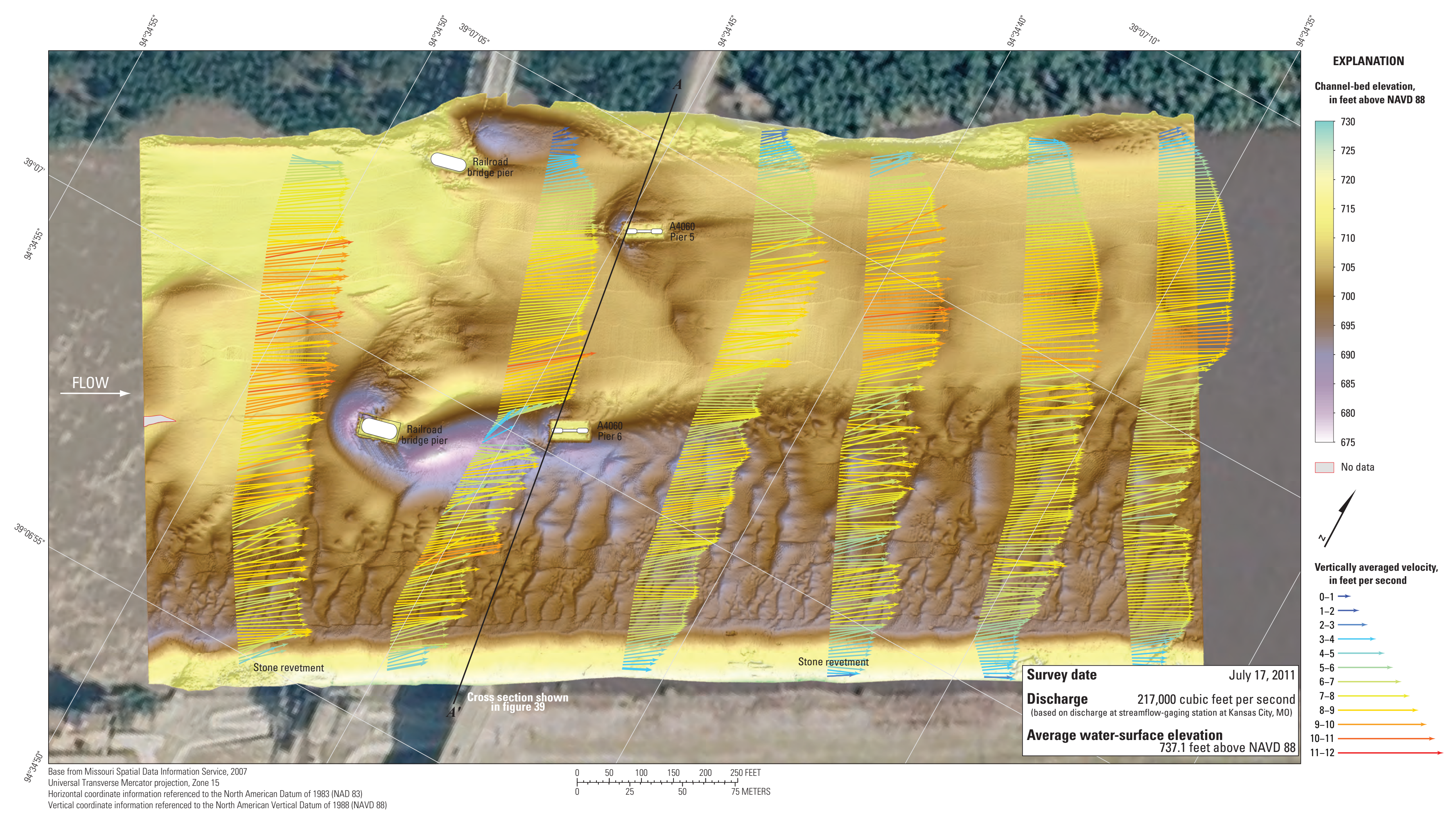

Figure 41. Bathymetry and vertically averaged velocities of the Missouri River channel in the vicinity of structure A4060 on State Highway 9 in Kansas City, Missouri. 


\section{Structure A7650 on Interstate 35 in Kansas City, Missouri}

Structure A7650 (site 10) on Interstate 35 crosses the Missouri River at RM 364.7, immediately north of downtown Kansas City, Missouri (fig. 1), and approximately 4,300 ft downstream from structure A4060 on State Highway 9. The site was surveyed on July 17, 2011, and the average watersurface elevation of the river in the survey area, determined by the RTK GPS tide solution, was $736.4 \mathrm{ft}$ (table 5). Flow on the Missouri River was about 217,000 $\mathrm{ft}^{3} / \mathrm{s}$ during the survey, according to the streamgage at Kansas City, Missouri (table 5).

The survey area was about 1,640 ft long and about $850 \mathrm{ft}$ wide, extending from bank to bank in the main channel (fig. 42). The upstream end of the survey area was about $700 \mathrm{ft}$ upstream from the centerline of structure A7650 at the pylon (fig. 42). The channel-bed elevations ranged from about 690 to $718 \mathrm{ft}$ for most of the surveyed area (5 to 95 percentile range of the bathymetric data), except in the vicinity of the pylon and the old pier of structure L0734 upstream from structure A7650 (fig. 42). Unlike upstream structures A4649 and A4060, there was no definitive thalweg along either side of the channel (fig. 42). A few large dune features were detected on the left (north) side of the channel upstream from the bridge, and numerous medium and small dunes and ripples were present throughout the rest of the channel (fig. 42). Downstream from the spur dike on the left (north) side of the downstream reach, the elevations were 12 to $17 \mathrm{ft}$ higher than elevations on the right side (fig. 42). Stone revetment was present on the right (south) bank throughout the reach (fig. 42), and appeared to have an area where it had slumped near the downstream end of the reach.
The main channel pylon appeared to be surrounded by a mound of rock riprap, with a local minimum channel-bed elevation of about $678 \mathrm{ft}$ near the downstream left (north) corner (figs. 42, 43; table 6). The top of the riprap around the upstream face of the pylon were at an elevation of about $699 \mathrm{ft}$, which is slightly below the elevation of the bottom of the pylon seal course of $699.50 \mathrm{ft}$ (table 6); the top of the riprap along the sides of the pylon is lower than at the upstream face (fig. 43). Several piles of particulate rock were observed in the channel near structure A7650. The minimum channelbed elevation in the vicinity of the pylon was about $21 \mathrm{ft}$ below the elevation of the bottom of the pylon seal course (fig. 43; table 6). Information from bridge plans indicates that the pylon is founded on shafts drilled $32 \mathrm{ft}$ into bedrock, with about $31 \mathrm{ft}$ of bed material between the bottom of the scour hole and bedrock (fig. 43; table 6). A scour hole with a minimum channel-bed elevation of $679 \mathrm{ft}$ was observed near the old pier of structure L0734 upstream from structure A7650, but this pier was in the process of being demolished at the time of the survey. The surveyed bed generally was similar to the original ground line from bridge plans (2008), with an area of 15 to $20 \mathrm{ft}$ of scour to the left of the pylon and an area of 15 to $20 \mathrm{ft}$ of deposition downstream from the old pier of structure L0734 (fig. 43).

The vertically averaged velocity vectors indicate mostly uniform flow throughout most of the channel, with velocities ranging from about 5 to $10 \mathrm{ft} / \mathrm{s}$ (fig. 44), except downstream from the rocky left (north) bank near the bridge. Substantial turbulence was observed downstream from the main channel pylon (fig. 44), likely as a result of the pylon being skewed to flow.

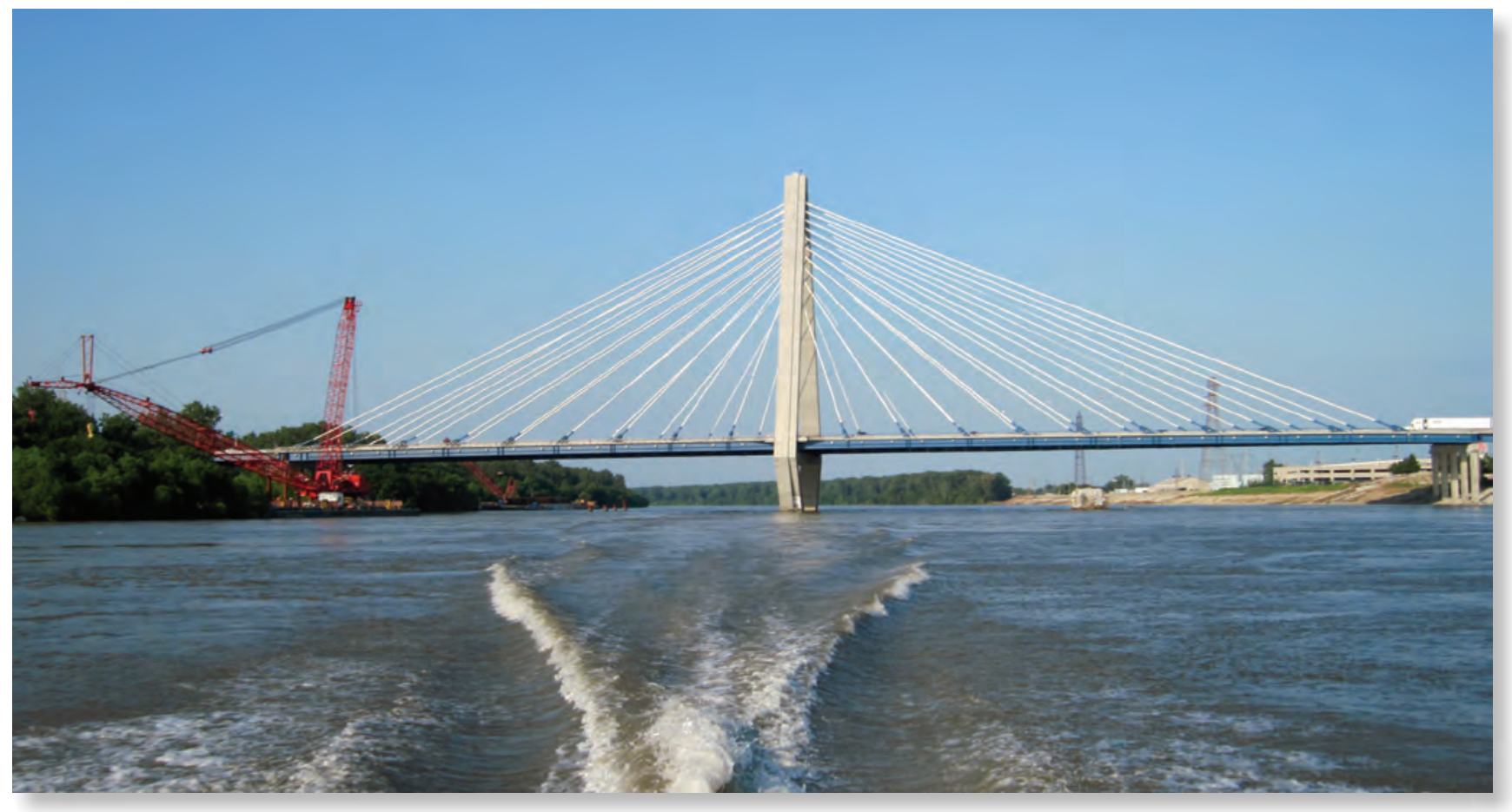

Structure A7650 on Interstate 35 in Kansas City, Missouri. 


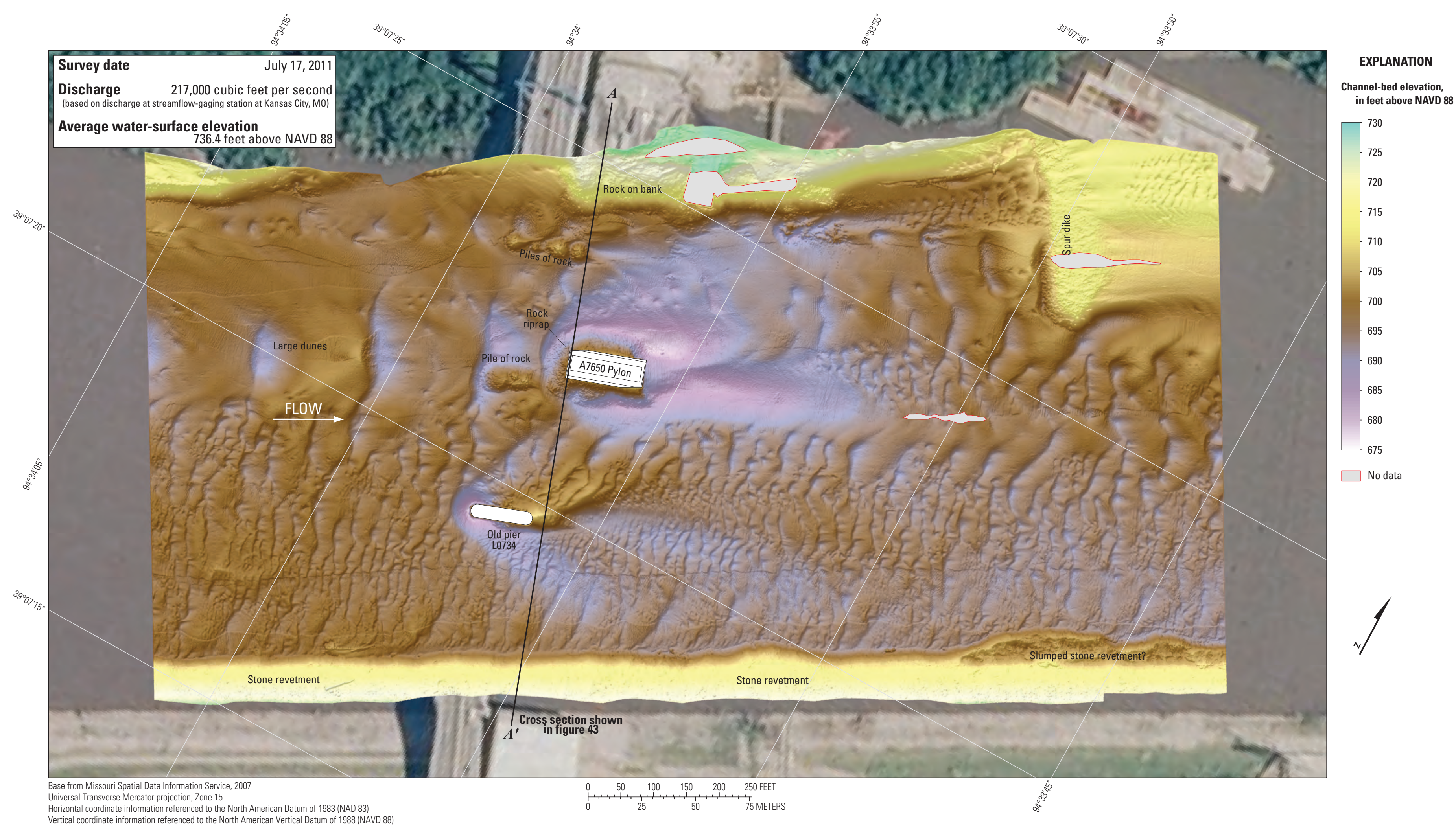

Figure 42. Bathymetric survey of the Missouri River channel in the vicinity of structure A7650 on Interstate 35 in Kansas City, Missouri. 


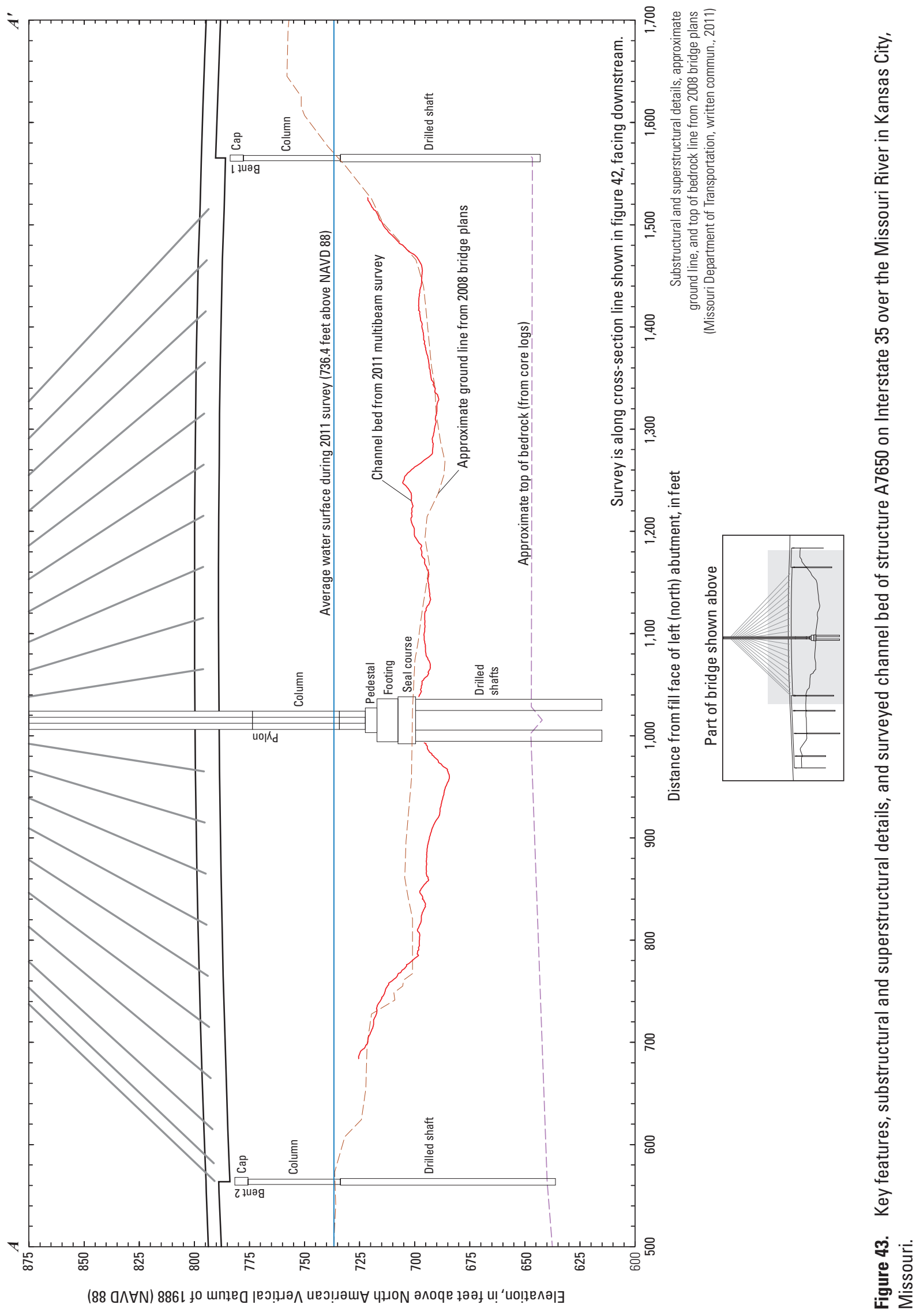




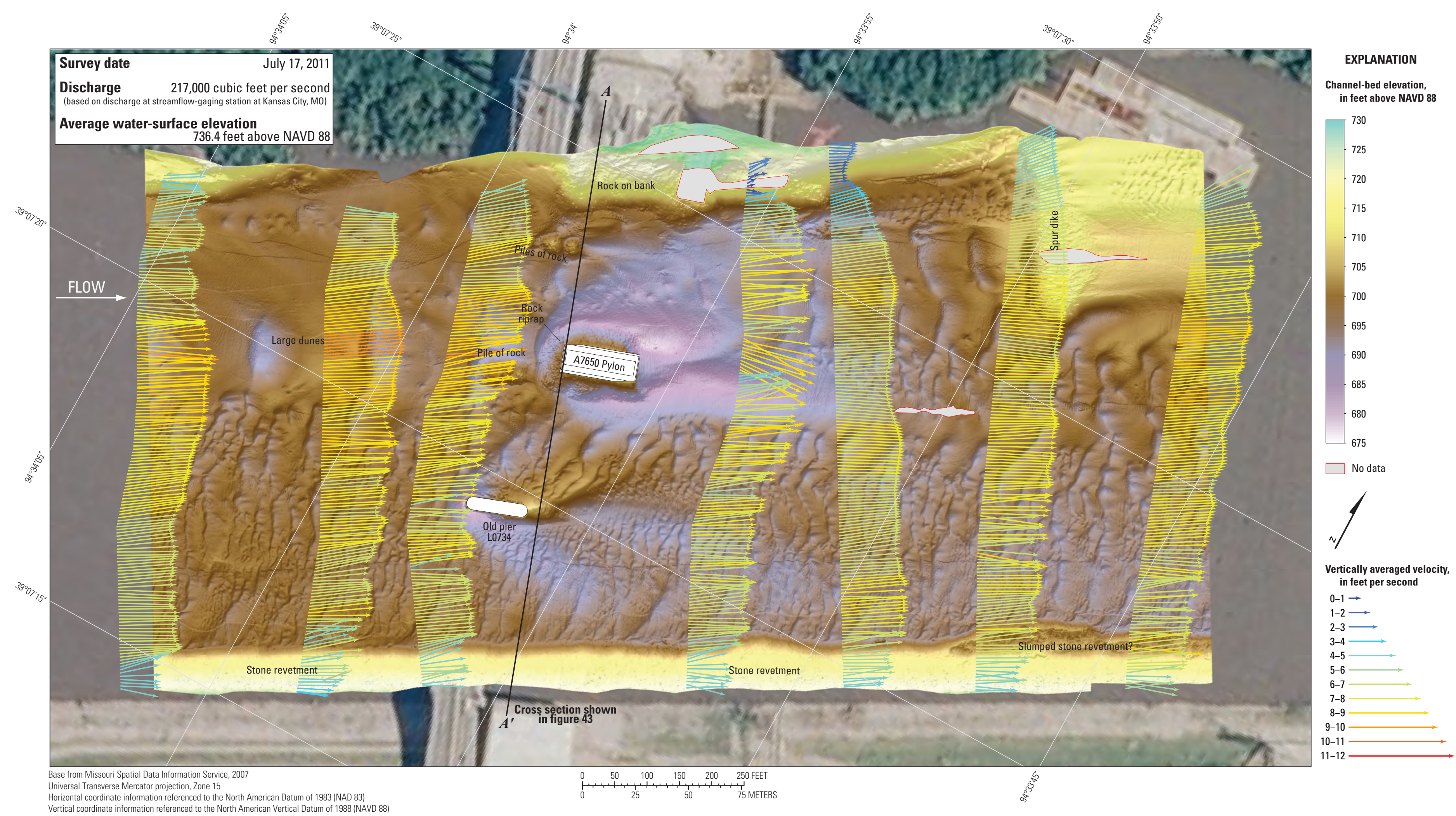

Figure 44. Bathymetry and vertically averaged velocities of the Missouri River channel in the vicinity of structure A7650 on Interstate 35 in Kansas City, Missouri. 


\section{Structure A5817 on State Highway 269 in Kansas City, Missouri}

Structure A5817 (site 11) on State Highway 269 crosses the Missouri River at RM 362.3, northeast of downtown Kansas City, Missouri (fig. 1). The site was surveyed on July 18,2011 , and the average water-surface elevation of the river in the survey area, determined by the RTK GPS tide solution, was $733.7 \mathrm{ft}$ (table 5). Flow on the Missouri River was about $212,000 \mathrm{ft}^{3} / \mathrm{s}$ during the survey, according to the streamgage at Kansas City, Missouri (table 5).

The survey area was about 1,640 ft long and about $970 \mathrm{ft}$ wide, extending from bank to bank in the main channel (fig. 45). Piers 2 and 3 were in the water and away from the banks and the upstream end of the survey area was about $670 \mathrm{ft}$ upstream from the centerline of structure A5817 at pier 2 (fig. 45). The channel-bed elevations ranged from about 691 to $713 \mathrm{ft}$ for most of the surveyed area (5 to 95 percentile range of the bathymetric data; fig. 45). A deep thalweg along the left (north) bank throughout the surveyed area contained evidence of bedrock exposure, and was about $25 \mathrm{ft}$ deeper than the channel bed in the middle of the channel (fig. 45). One large dune feature was observed in the upstream reach, and numerous medium to small dunes and ripples were present throughout the rest of the channel, particularly along the right (south) bank (fig. 45). In addition to the rock outcrops on the left (north) bank, stone revetment also was present on the left bank throughout the reach (fig. 45). The channel bed was dynamic between survey passes, particularly in the thalweg, resulting in discrepancies between the swathes that appear as longitudinal stripes in the survey (fig. 45).

In the vicinity of main channel pier 2 (fig. 45), a minor scour hole had a minimum channel-bed elevation of about $702 \mathrm{ft}$ (table 6), about $14 \mathrm{ft}$ above the elevation of the bottom of the pier seal course of $687.26 \mathrm{ft}$ (fig. 46; table 6). The top of the pier footing was evident along the right (south) side of the pier during the survey (fig. 45). The minor scour hole near pier 3 was difficult to discern from nearby small dunes and ripples (fig. 45). Information from bridge plans indicates that piers 2 and 3 of structure A5817 are founded on shafts drilled $20 \mathrm{ft}$ into bedrock, with about $25 \mathrm{ft}$ of bed material between the bottom of the scour hole and bedrock at pier 2 and about $48 \mathrm{ft}$ of material at pier 3 (fig. 46; table 6).

The difference between the survey on July 18, 2011, and the previous survey on March 17, 2010 (fig. 47) indicates substantial deposition throughout the reach from 2010 to 2011, with an average difference $+3.30 \mathrm{ft}$ between the bathymetric surfaces (table 7). There were a few areas of scour from 2010 to 2011, predominantly in the upstream reach: near the large dune feature and the various smaller dunes and ripples in the middle of the channel, and along the right (south) bank (fig. 47). The cross sections from the two surveys also indicate substantial deposition throughout (fig. 46), despite a water-surface elevation difference of nearly $10 \mathrm{ft}$ and a flow difference of $88,000 \mathrm{ft}^{3} / \mathrm{s}$ (table 7). Whereas the scour hole near main channel pier 2 was below the seal course in 2010, in 2011 it was at the top of the footing (fig. 46). The stone revetment on the left (north) bank appeared to have several areas of localized scour in the upstream reach (fig. 47).

The vertically averaged velocity vectors indicate mostly uniform flow throughout the reach, ranging from about $4 \mathrm{ft} / \mathrm{s}$ along the inside of the bend on the right (south) bank to $12 \mathrm{ft} / \mathrm{s}$ near the downstream thalweg (fig. 48). Flow was angled to the left (north) in the upstream part of the reach because of the bend in the channel (fig. 48). Moderate to substantial turbulence was observed along the thalweg near bedrock outcrops, and along the inside of the bend along the right (south) bank (fig. 48).

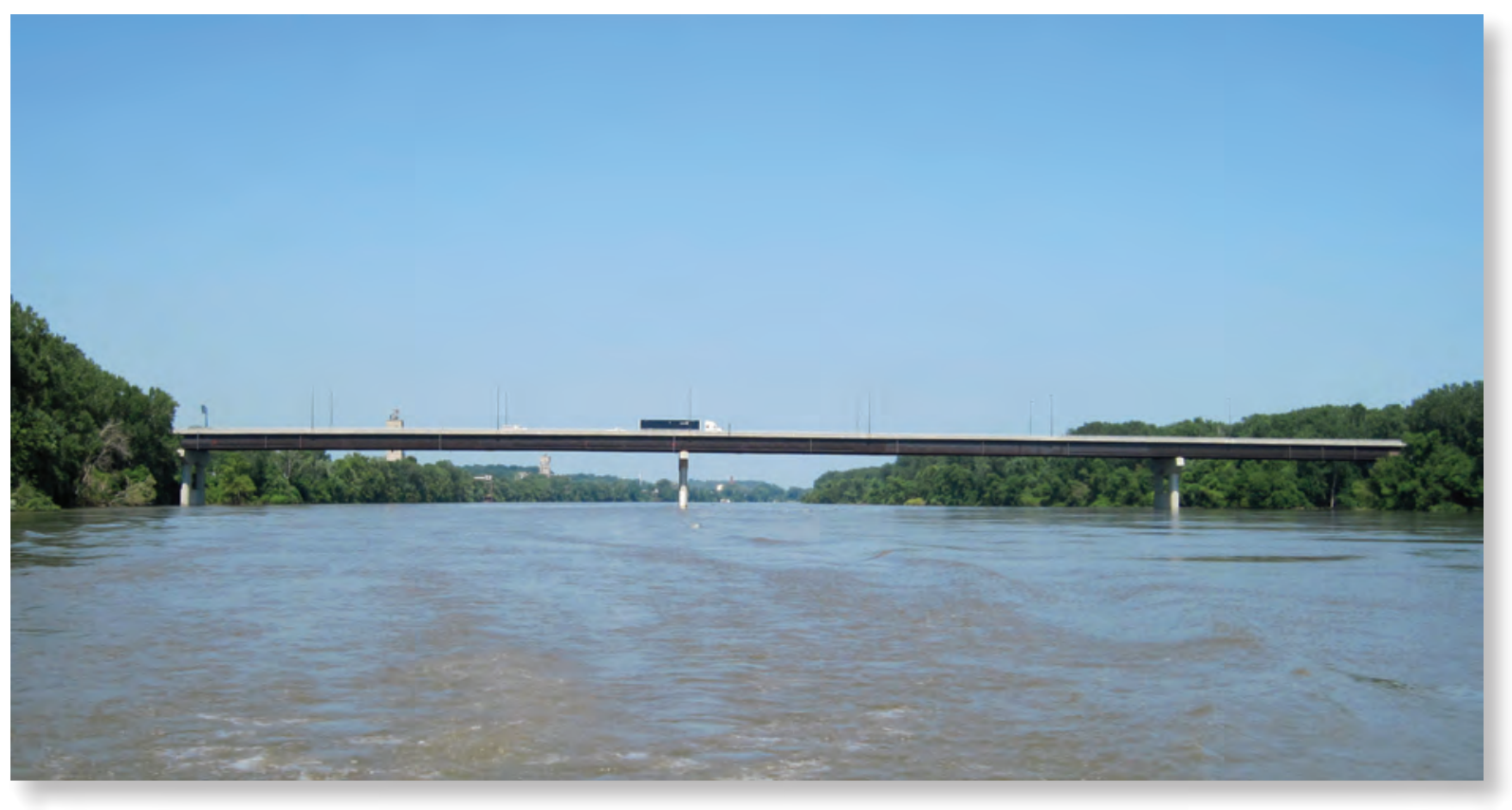

Structure A5817 on State Highway 269 in Kansas City, Missouri. 


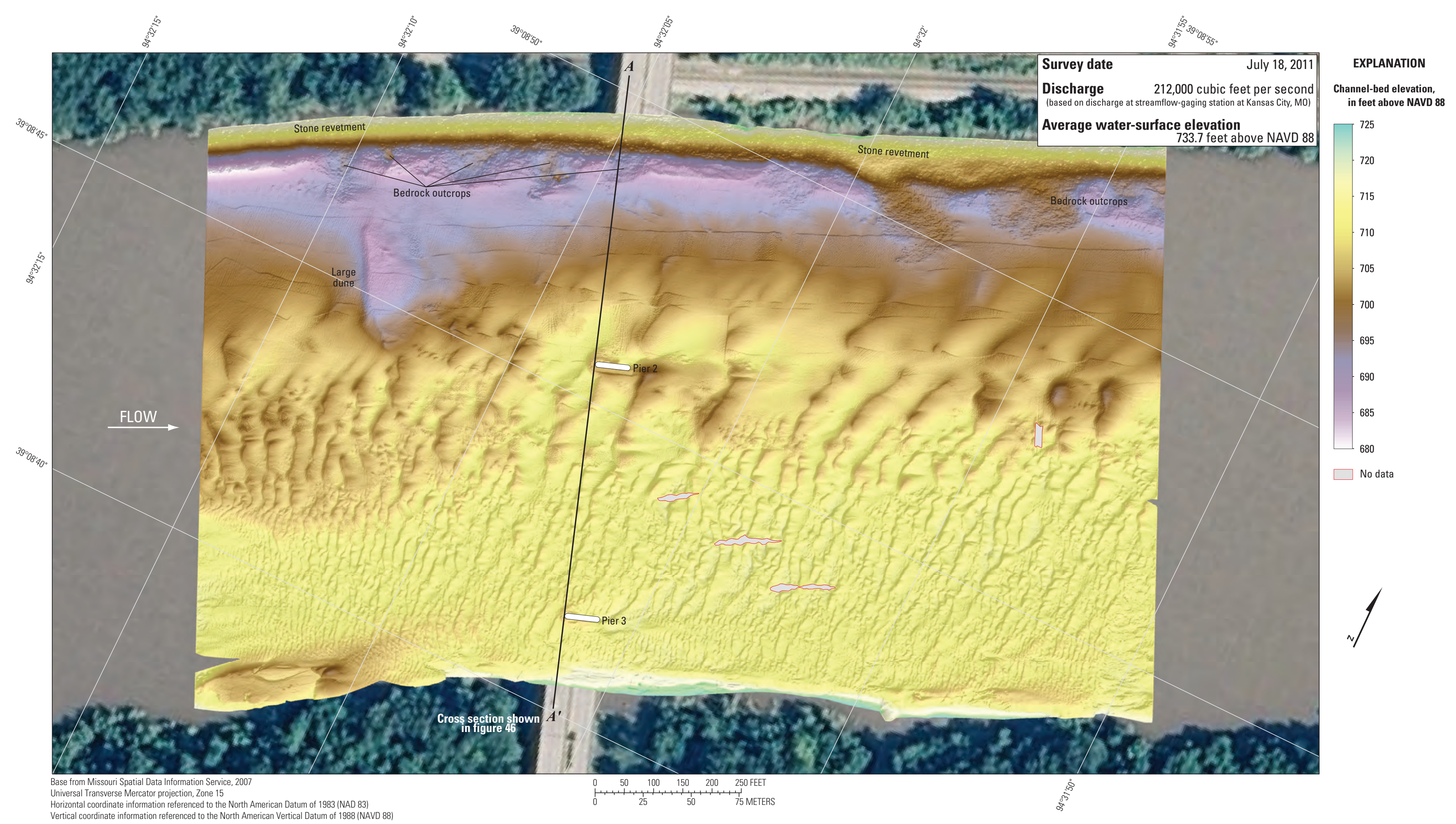

Figure 45. Bathymetric survey of the Missouri River channel in the vicinity of structure A5817 on State Highway 269 in Kansas City, Missouri. 


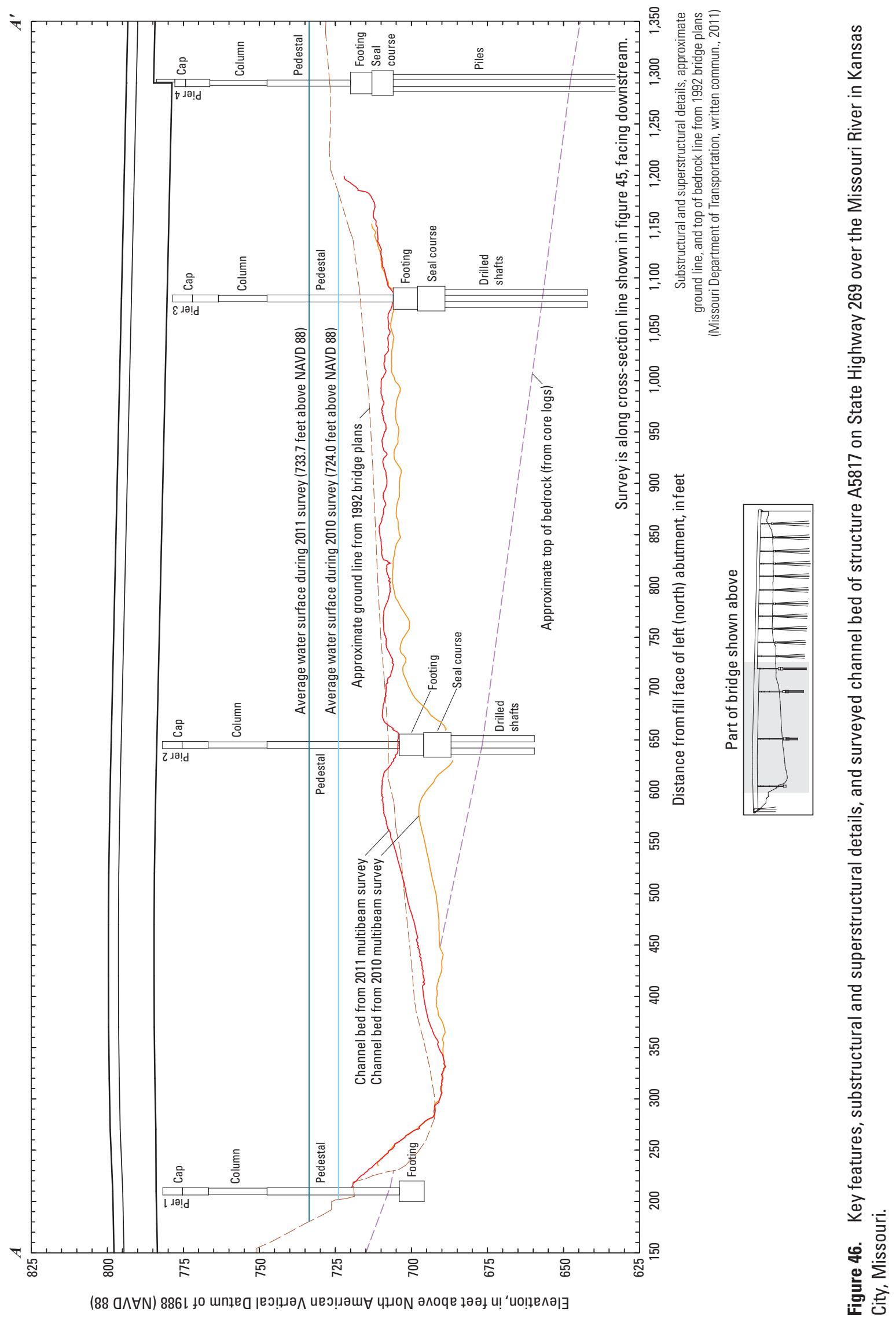




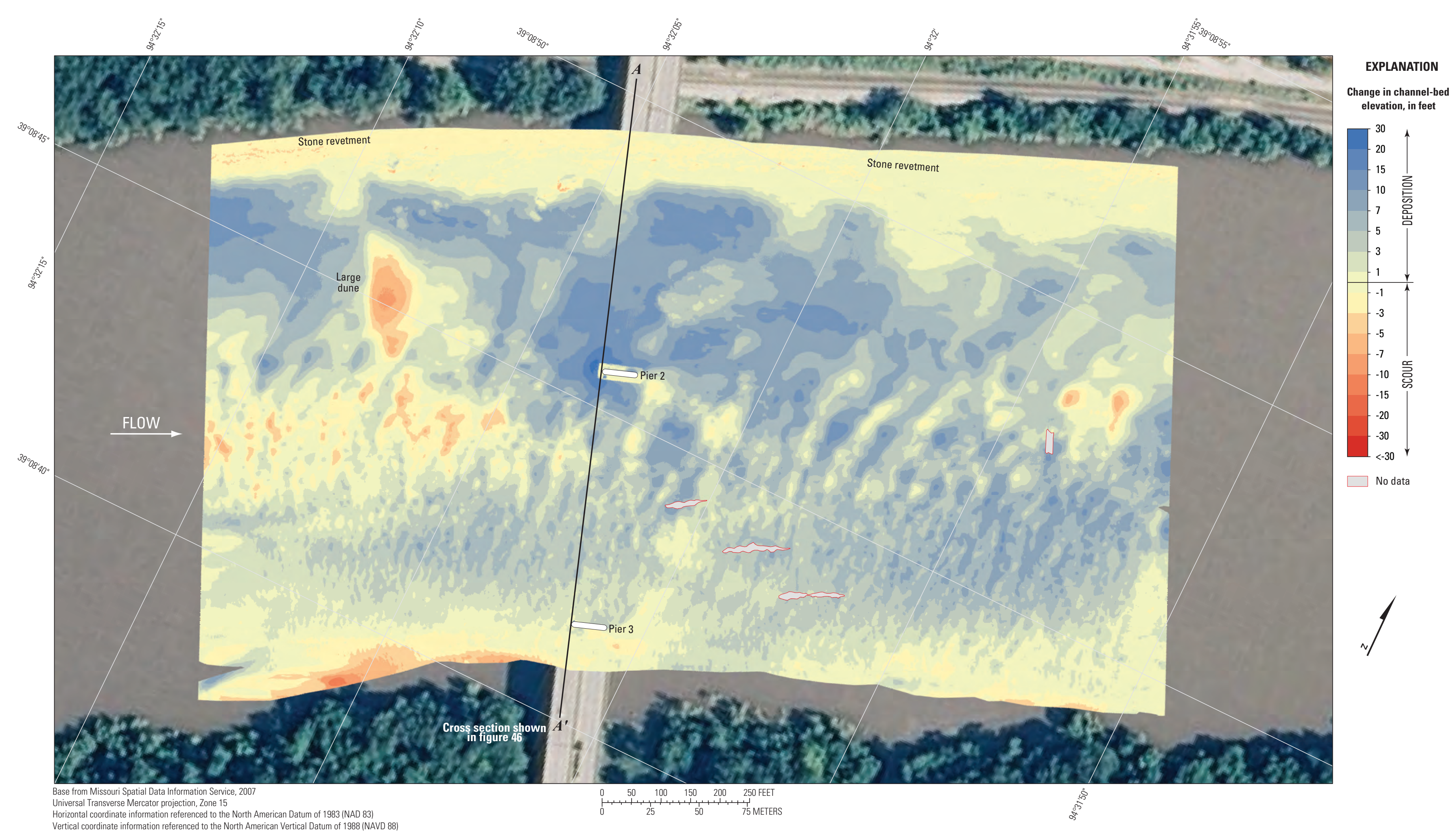

Figure 47. Difference between surfaces created from bathymetric surveys of the Missouri River channel in the vicinity of structure A5817 on State Highway 269 in Kansas City, Missouri, on March 17, 2010, and July 18, 2011 . 


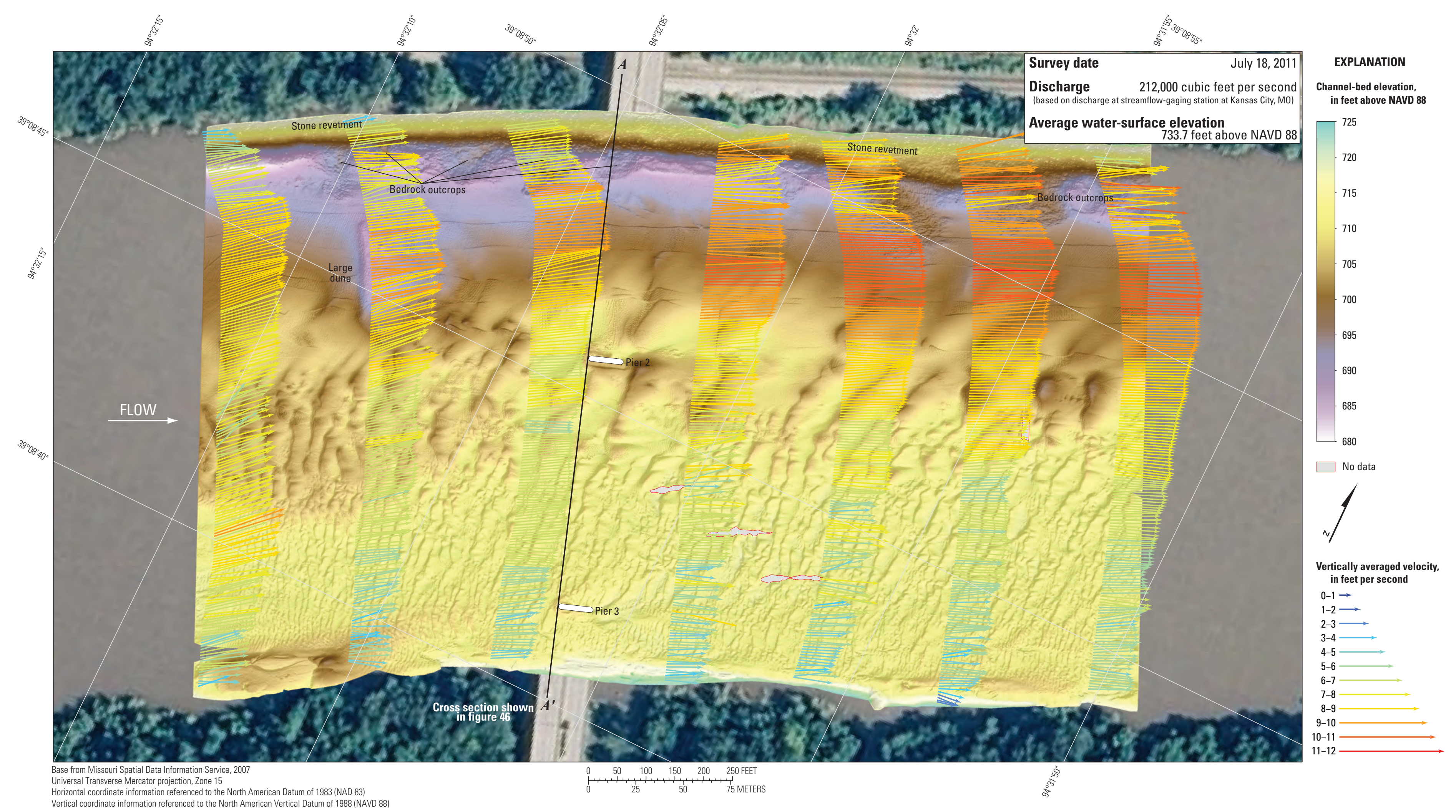

Figure 48. Bathymetry and vertically averaged velocities of the Missouri River channel in the vicinity of structure A5817 on State Highway 269 in Kansas City, Missouri. 


\section{Structure A0767 on Interstate 435 in Kansas City, Missouri}

Structure A0767 (site 12) on Interstate 435 crosses the Missouri River at RM 360.3, on the northeastern side Kansas City, Missouri (fig. 1). The site was surveyed on July 18, 2011, and the average water-surface elevation of the river in the survey area, determined by the RTK GPS tide solution, was $732.3 \mathrm{ft}$ (table 5). Flow on the Missouri River was about $212,000 \mathrm{ft}^{3} / \mathrm{s}$ during the survey, according to the streamgage at Kansas City, Missouri (table 5).

The survey area was about $1,640 \mathrm{ft}$ long and about $890 \mathrm{ft}$ wide, extending from bank to bank in the main channel (fig. 49). Piers 7 and 8 were in the water and away from the banks at structure A0767; however, pier 8 was immediately downstream from a spur dike and was surrounded by a substantial debris raft, and only limited bathymetric data could be obtained near it (fig. 49). The upstream end of the survey area was about $660 \mathrm{ft}$ upstream from the centerline of structure A0767 at pier 7 (fig. 49). The channel-bed elevations ranged from about 691 to $713 \mathrm{ft}$ for most of the surveyed area ( 5 to 95 percentile range of the bathymetric data), except downstream from the tip of the spur dike and an unidentified object in the channel downstream from structure A0767, near pier 7 of structure A0767, and in the downstream reach near the rock outcrop on the left (north) bank (fig. 49). The channel thalweg was along the left (north) bank throughout the surveyed area, and became deeper in the downstream direction. The channel was filled with numerous large and very large dune features, as well as numerous medium and small dunes and ripples along the right (south) bank (fig. 49). Along the inside of the bend in the downstream reach, deposits reached an elevation of about $706 \mathrm{ft}$ (fig. 49).

In the immediate vicinity of main channel pier 7 (fig. 49), the scour hole had a minimum channel-bed elevation of about $674 \mathrm{ft}$ (table 6), about $15 \mathrm{ft}$ below the elevation of the bottom of the pier seal course of $689.26 \mathrm{ft}$ (fig. 50; table 6). The upstream end of pier 8 was embedded in the rock spur dike, and could not be surveyed because of a substantial debris raft (fig. 49). The top of the footing on the downstream end of the pier was visible (fig. 49), but the minimum channel elevation was $700 \mathrm{ft}$, nearly $11 \mathrm{ft}$ higher than the bottom of the seal course elevation of $689.26 \mathrm{ft}$ (fig. 49; table 6). Information from bridge plans indicates that piers 7 and 8 are founded on shafts drilled $20 \mathrm{ft}$ into bedrock, with about $14 \mathrm{ft}$ of bed material between the bottom of the scour hole and bedrock at pier 7 and about $52 \mathrm{ft}$ of material at pier 8 (fig. 50; table 6). A point cloud visualization of the multibeam depth points obtained during the survey at pier 7 indicates the bottom of the seal course as a sonic "shadow," with the sides of drilled shafts appearing as points in the shadow (fig. 51).

The difference between the survey on July 18, 2011, and the previous survey on March 17, 2010 (fig. 52) indicates moderate scour throughout the reach from 2010 to 2011, with an average difference of $-1.86 \mathrm{ft}$ between the bathymetric surfaces (table 7). There were a few areas of deposition, predominantly in the middle of the channel near the large dune features and the various smaller dunes and ripples (fig. 52). The cross sections from the two surveys are similar to each other, with the 2011 survey generally being below the 2010 survey section (fig. 52), despite a water-surface elevation difference of nearly $10 \mathrm{ft}$ and a flow difference of $89,000 \mathrm{ft}^{3} / \mathrm{s}$ (table 7). The scour hole near pier 7 was slightly deeper and longer on the right (south) side in 2011 than in 2010, as evidenced by the horseshoe-shaped area of additional scour around it (figs. 51, 52). The stone revetment on the left (north) bank appeared to have several areas of localized shifting, resulting in the appearance of deposition and scour (fig. 52).

The vertically averaged velocity vectors indicate mostly uniform flow throughout the reach, ranging from about $3 \mathrm{ft} / \mathrm{s}$ along the inside of the bend on the right (south) bank to $12 \mathrm{ft} / \mathrm{s}$ in the thalweg (fig. 53). Flow was angled to the right (south) near the upstream face of the bridge, and there was flow reversal downstream from the spur dike, debris raft, and pier 8 (fig. 53). Moderate to substantial turbulence was observed in several transects (fig. 53).

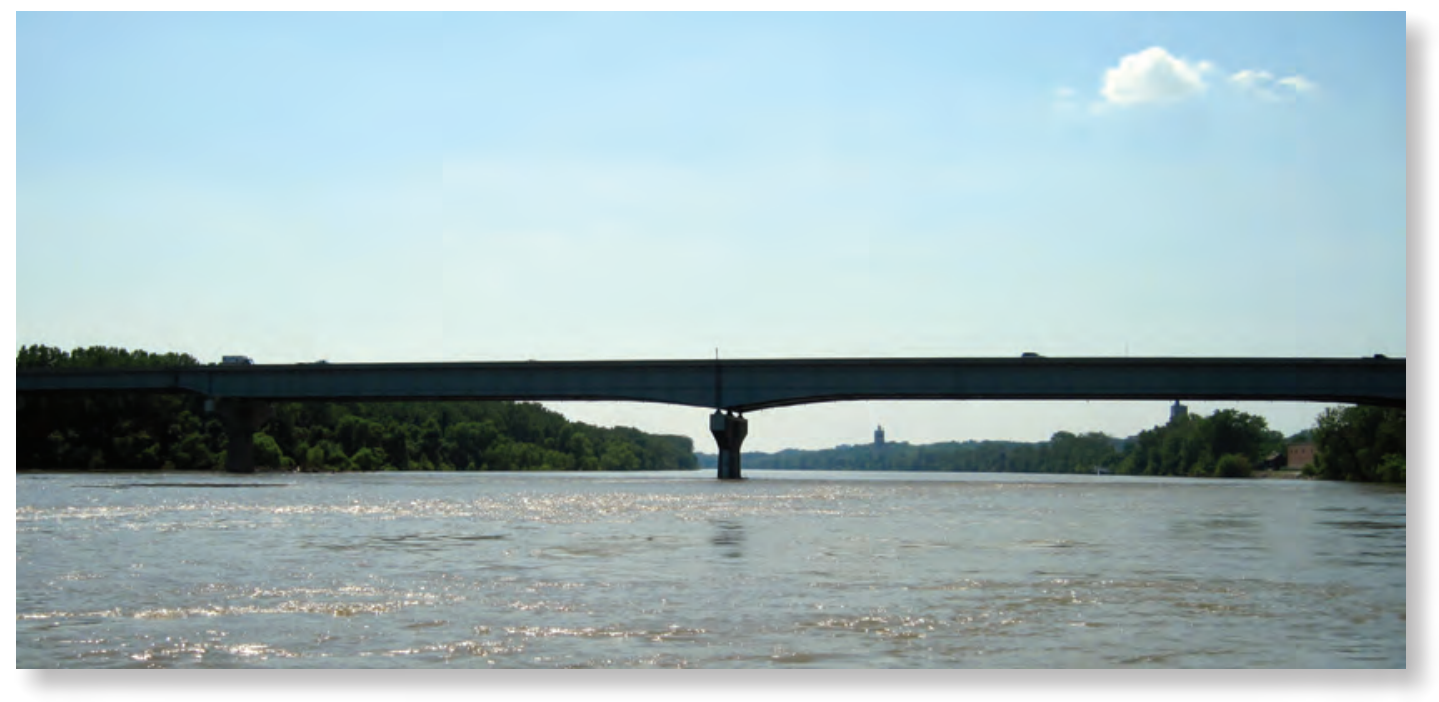

Structure A0767 on Interstate 435 in Kansas City, Missouri. 


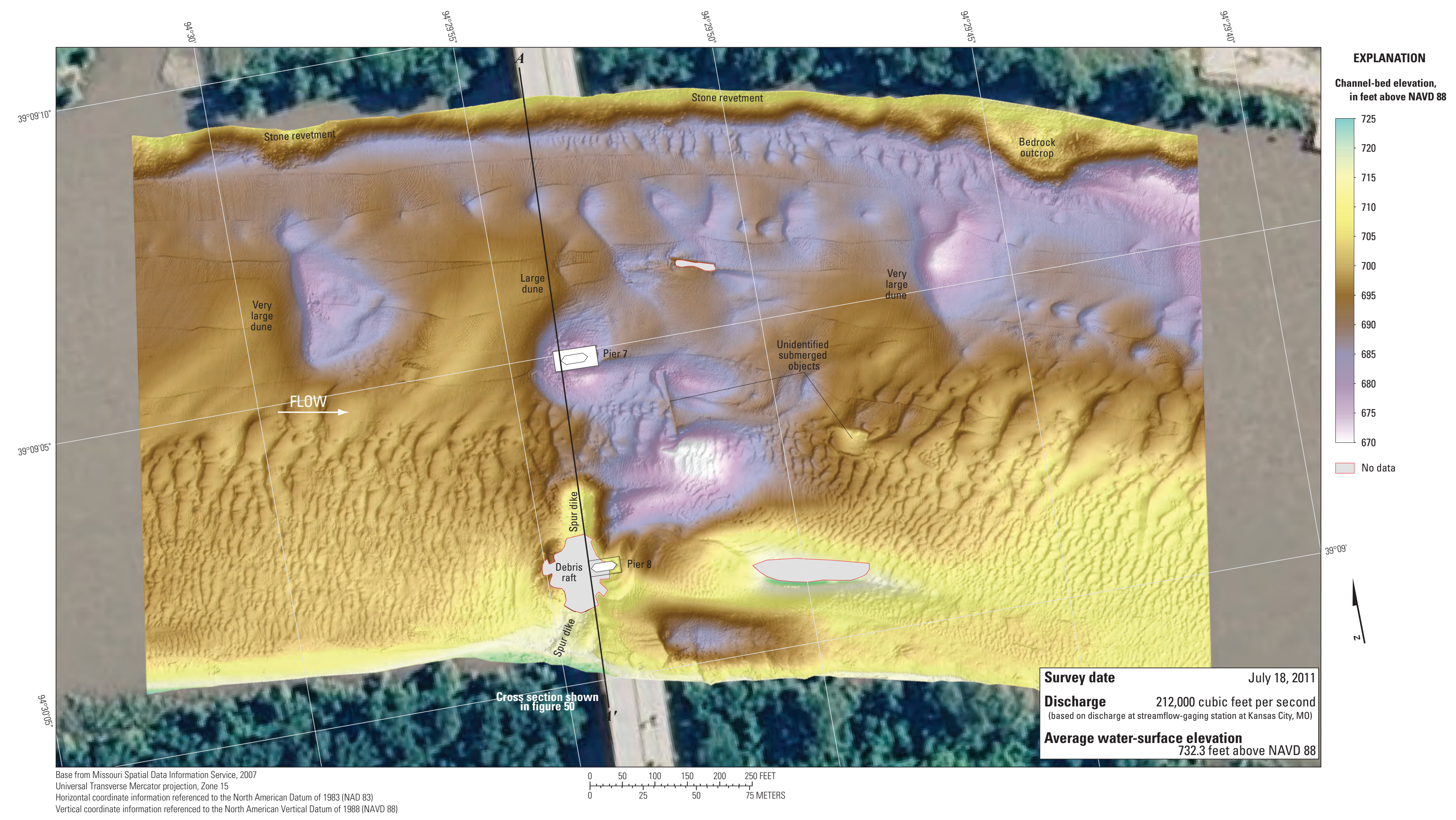

Figure 49. Bathymetric survey of the Missouri River channel in the vicinity of structure A0767 on Interstate 435 in Kansas City, Missouri. 


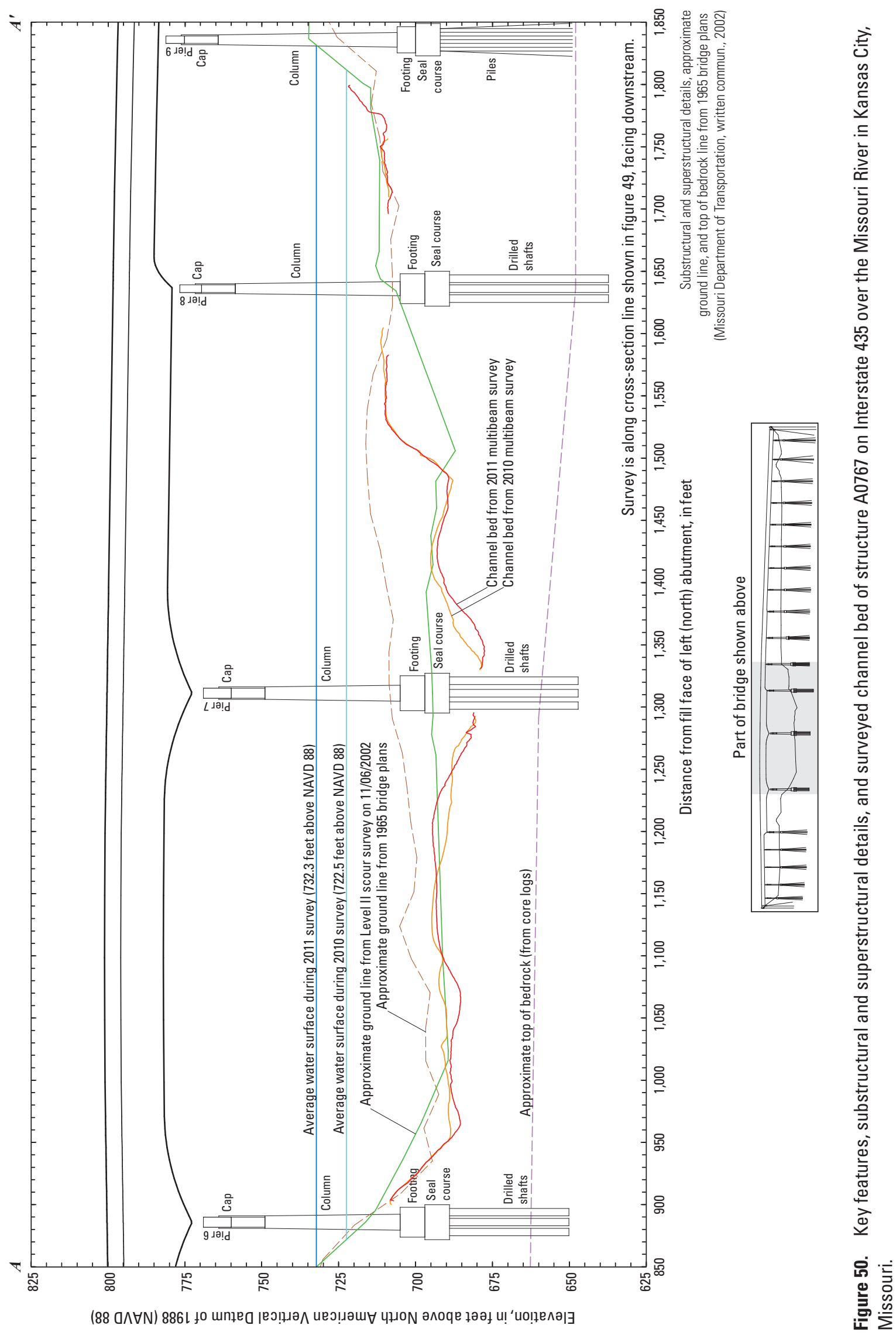




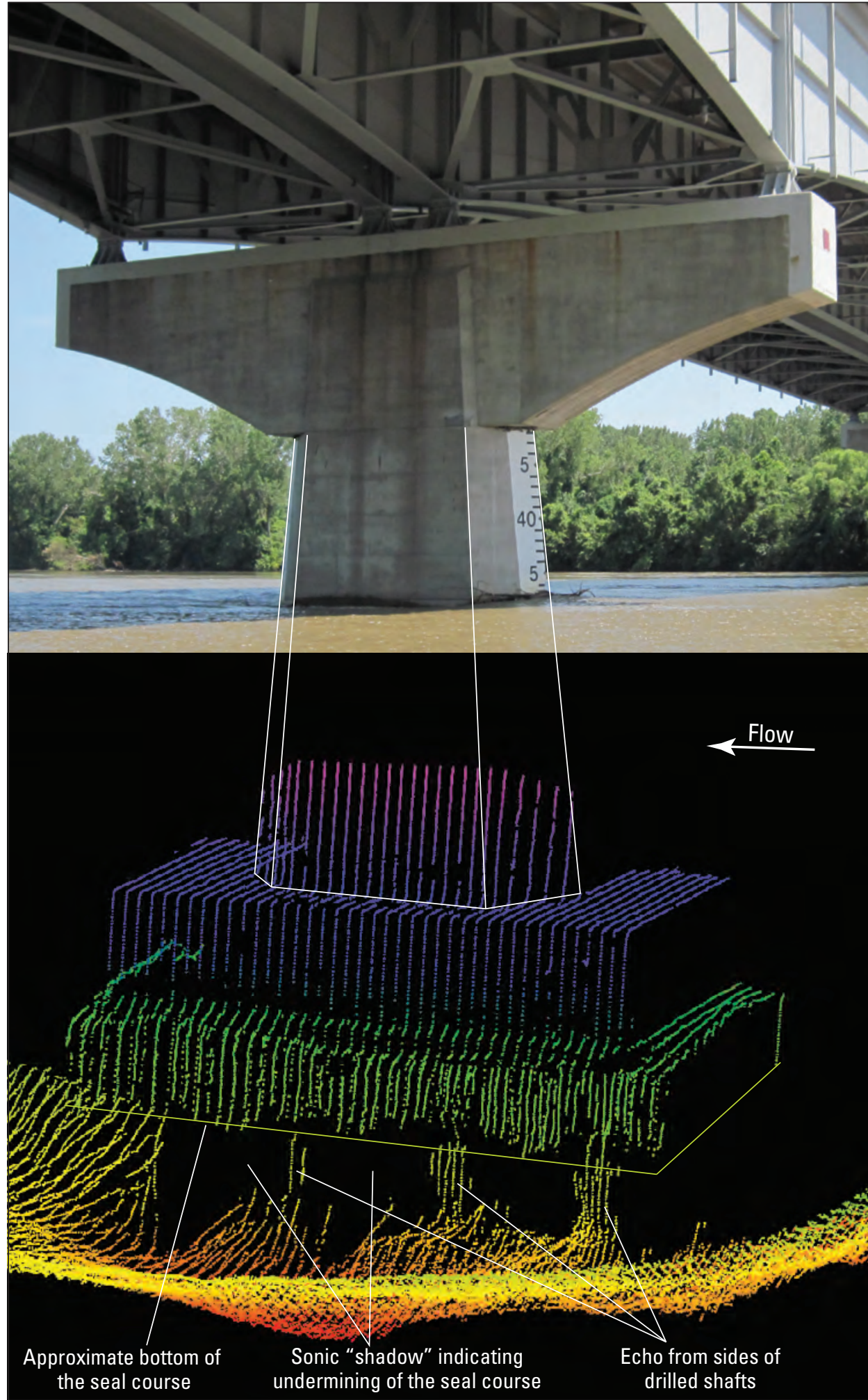

\section{EXPLANATION}

Elevation of point, in feet above the North American Vertical Datum of 1988

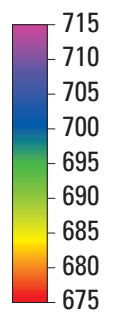

Figure 51. Point cloud visualization of the channel bed and left (north) side of main channel pier 7 of structure A0767 on Interstate 435 over the Missouri River in Kansas City, Missouri. 


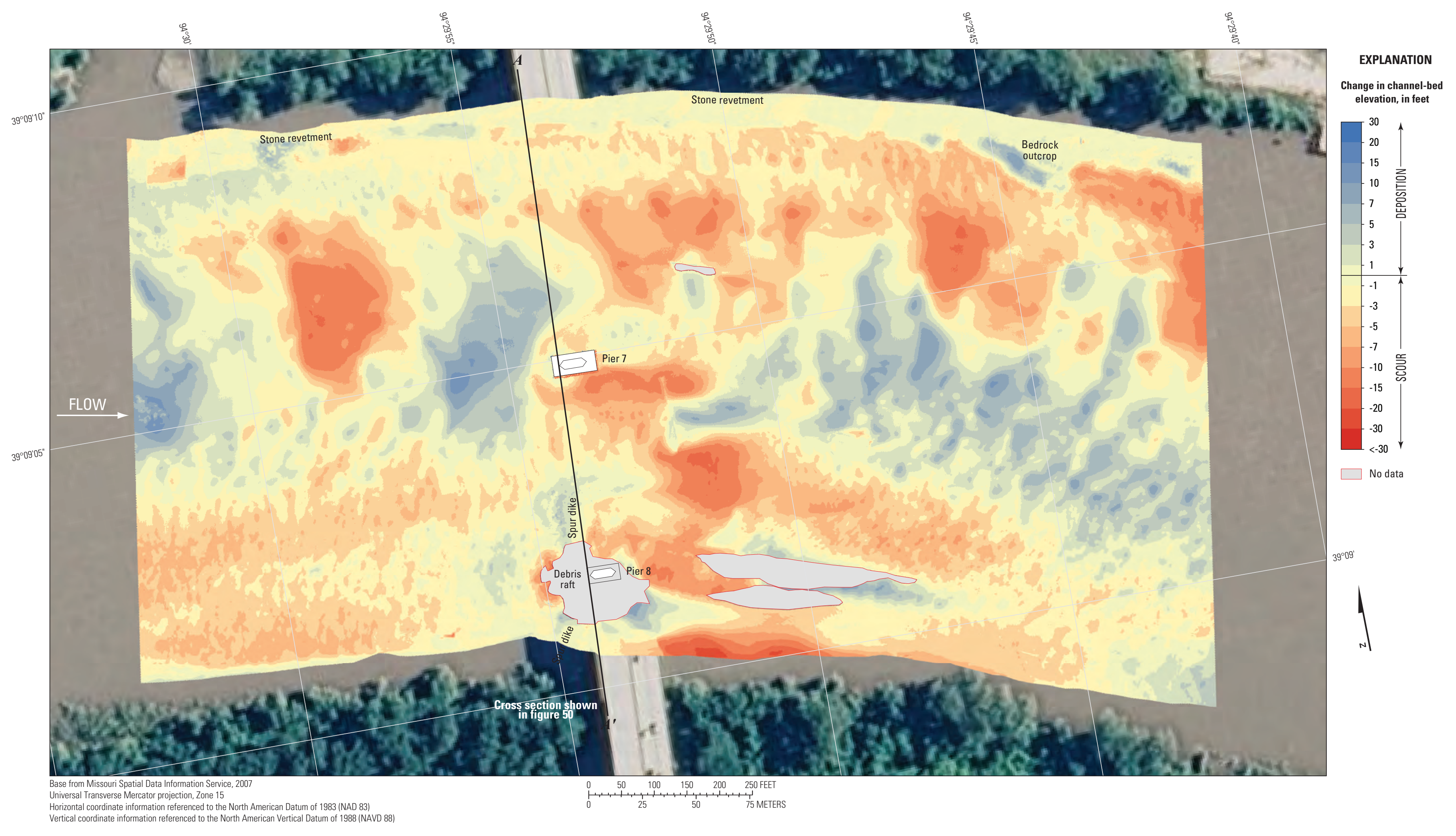

Figure 52. Difference between surfaces created from bathymetric surveys of the Missouri River channel in the vicinity of structure A0767 on Interstate 435 in Kansas City, Missouri, on March 17, 2010 , and July 18, 2011. 


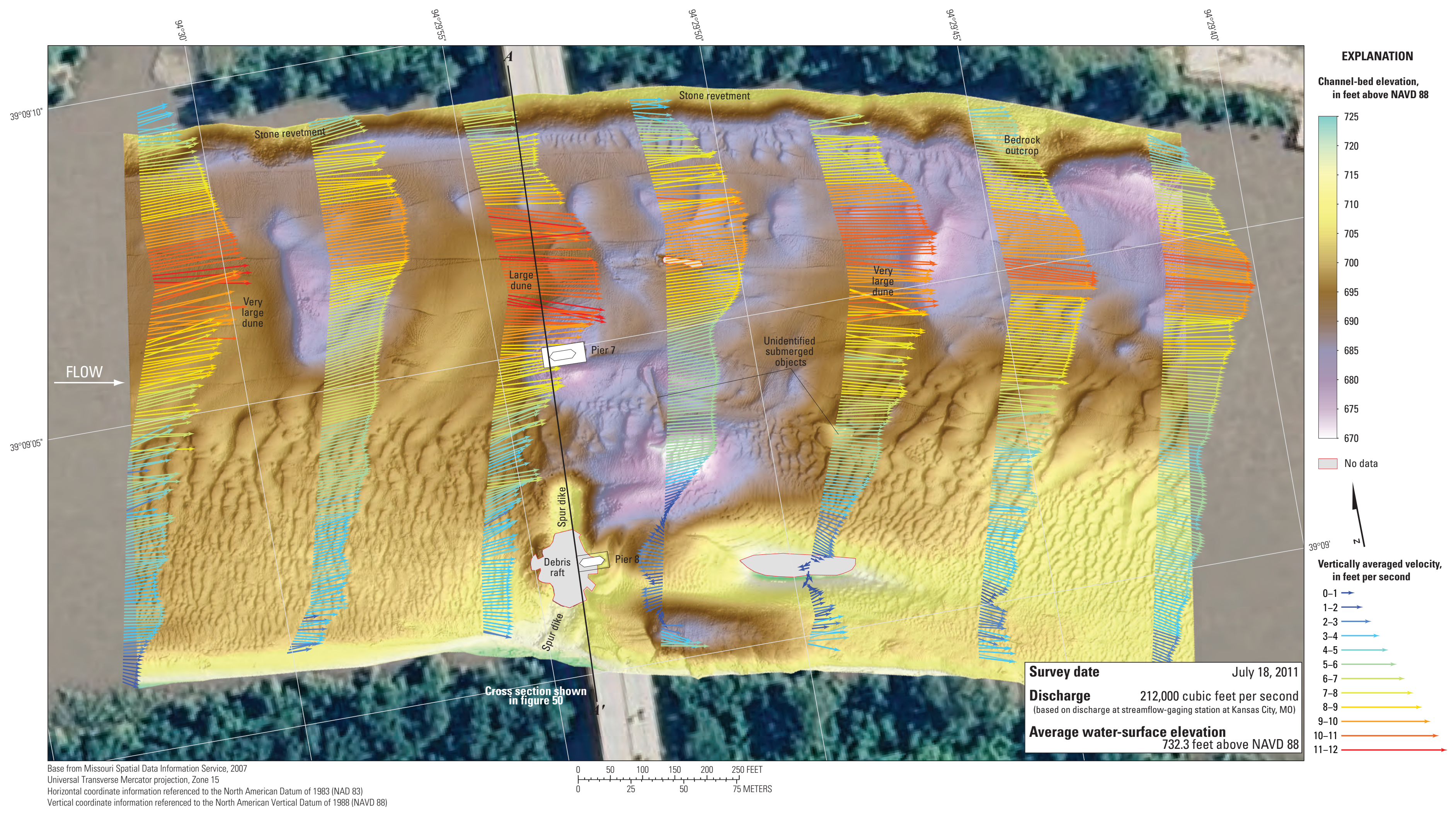

Figure 53. Bathymetry and vertically averaged velocities of the Missouri River channel in the vicinity of structure A0767 on Interstate 435 in Kansas City. Missouri 


\section{Structures A4757 and L0568 on State Highway 291 in Kansas City, Missouri}

Structures A4757 and L0568 (site 13) are dual bridges on State Highway 291, crossing the Missouri River at RM 352.7 on the northeastern side of Kansas City, Missouri (fig. 1). The site was surveyed on July 19, 2011, and the average watersurface elevation of the river in the survey area, determined by the RTK GPS tide solution, was $726.7 \mathrm{ft}$ (table 5). Flow on the Missouri River was about 212,000 $\mathrm{ft}^{3} / \mathrm{s}$ during the survey, according to the streamgage at Kansas City, Missouri (table 5).

The survey area was about 1,640 ft long and about $850 \mathrm{ft}$ wide, extending from bank to bank in the main channel (fig. 54). The upstream end of the survey area was about $720 \mathrm{ft}$ upstream from the centerline between structures A4757 and L0568 (fig. 54). The channel-bed elevations ranged from about 674 to $703 \mathrm{ft}$ for most of the surveyed area (5 to 95 percentile range of the bathymetric data), except near the main channel piers of structures A4757 and L0568 (fig. 54). A narrow channel thalweg was along the left (north) bank at the upstream end of the surveyed area that deepened and widened in the downstream direction (fig. 54). Several large dune features were detected in the channel upstream from the bridges, as well as numerous medium and small dunes and ripples along the right (south) bank upstream from the bridge and across the channel downstream from the bridges (fig. 54). A noticeable channel constriction was at and immediately downstream from the bridges (fig. 54). The left (north) bank appeared to be covered with stone revetment (fig. 54).

In the vicinity of the main channel piers (fig. 54), a large scour hole encompassing both piers had a minimum channelbed elevation of about $662 \mathrm{ft}$ (table 6). The main channel piers were skewed to the approaching flow, which caused a wide scour hole with somewhat unique characteristics as compared to scour holes at the other surveyed bridges. Pier 5 of structure L0568 was in the wake of pier 2C of structure A4757, and, therefore, had no well-defined scour hole specific to it. The point of overall minimum channel-bed elevation in the reach occurred on the right (south) side of pier $2 \mathrm{C}$ of structure A4757 (fig. 54). At the upstream end of pier 2C of structure A4757, the minimum channel-bed elevation was about $666 \mathrm{ft}$, and at the upstream end of pier 5 of structure L0568, the minimum channel-bed elevation was about $669 \mathrm{ft}$ (fig. 54; table 6). Information from bridge plans indicates that the main channel pier of structure A4757 is founded on shafts drilled $20 \mathrm{ft}$ into bedrock (fig. 55), with about $43 \mathrm{ft}$ of bed material between the bottom of the scour hole and bedrock at the point of minimum elevation of the scour hole (table 6), and about $47 \mathrm{ft}$ of material near the upstream pier face (fig. 55). At the point of minimum elevation, the surveyed channel bed was about $4 \mathrm{ft}$ lower than the bottom of the seal course elevation of 666.26 $\mathrm{ft}$ (table 6). Information from bridge plans indicate that the main channel pier of structure L0568 is a caisson on bedrock (fig. 56), with about $44 \mathrm{ft}$ of bed material between the bottom of the scour hole and bedrock at the point of minimum elevation of the scour hole (table 6), and about $51 \mathrm{ft}$ of material near the upstream pier face (fig. 56).

The difference between the survey on July 19, 2011, and the previous survey on March 18, 2010 (fig. 57) indicates moderate scour throughout the reach from 2010 to 2011, with an average difference of $-2.32 \mathrm{ft}$ between the bathymetric surfaces (table 7). There were a few areas of deposition, predominantly in the upstream reach and around main channel pier 5 of downstream structure L0568 (fig. 57); however, additional scour of as much as $7 \mathrm{ft}$ had occurred around main channel pier 2C of upstream structure A4757. The cross sections from the 2011 survey are similar to but lower than the 2010 survey at both bridges (figs. 55, 56), likely as a result of the water-surface elevation difference of more than $9 \mathrm{ft}$ and a flow difference of $92,000 \mathrm{ft}^{3} / \mathrm{s}$ (table 7). The scour hole near pier $2 \mathrm{C}$ of structure A4757 was slightly narrower at the top and deeper in 2011 than in 2010 (figs. 55, 57), whereas the scour hole near pier 5 of structure L0568 was of a similar shape but shallower in 2011 than in 2010 (figs. 56, 57). As with several difference maps presented earlier in this report, the appearance of substantial deposition or scour at the faces of the piers results from minor horizontal positional variances between the surveys. The stone revetment on the upstream left (north) bank appeared to have experienced general scour, whereas the right (south) bank near the bridges and downstream appeared to have experienced deposition with localized scour downstream from structure L0568 (fig. 57).

The vertically averaged velocity vectors indicate mostly uniform flow throughout the reach, ranging from about $3 \mathrm{ft} / \mathrm{s}$ along the inside of the bend on the right (south) bank to nearly $12 \mathrm{ft} / \mathrm{s}$ in the thalweg (fig. 58). Flow was angled to the left (north) near the upstream and downstream faces of the bridges (fig. 58). Moderate turbulence was observed in several transects, particularly near the bank protrusions near the bridges and downstream from the main channel piers (fig. 58). Velocities were slightly lower downstream from the bridges, likely caused by the flow expansion downstream from the constriction at the bridges (fig. 58).

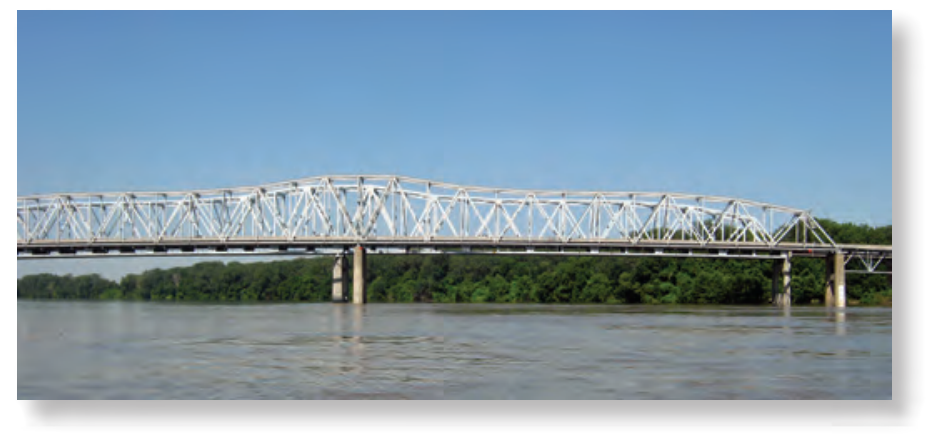

Structures A4757 and L0568 on State Highway 291 in Kansas City, Missouri. Structure L0568 is in the foreground and A4757 is in the background. Photograph by Joseph Richards, USGS. 


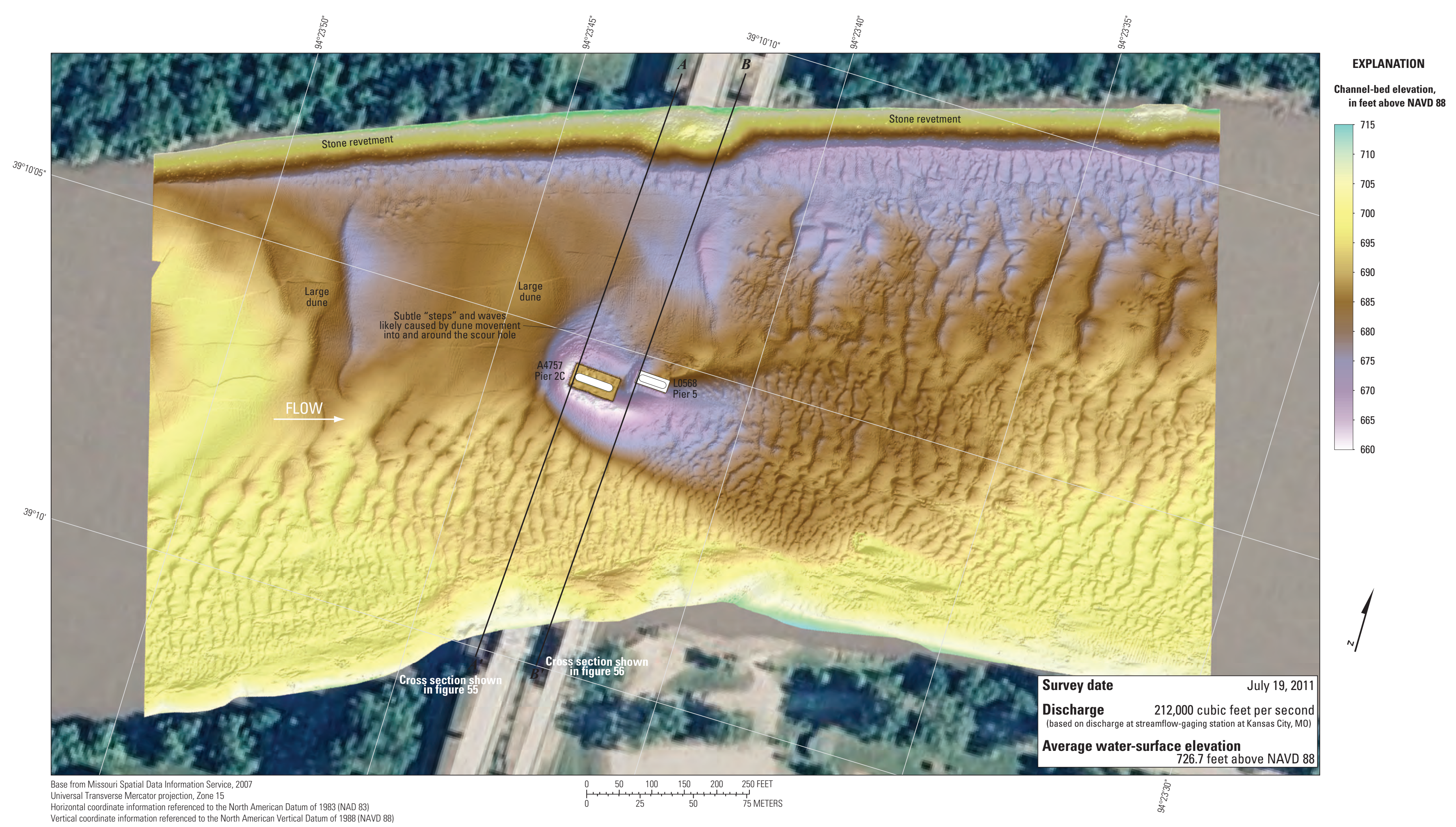

Figure 54. Bathymetric survey of the Missouri River channel in the vicinity of structures A4757 and L0568 on State Highway 291 in Kansas City, Missouri. 


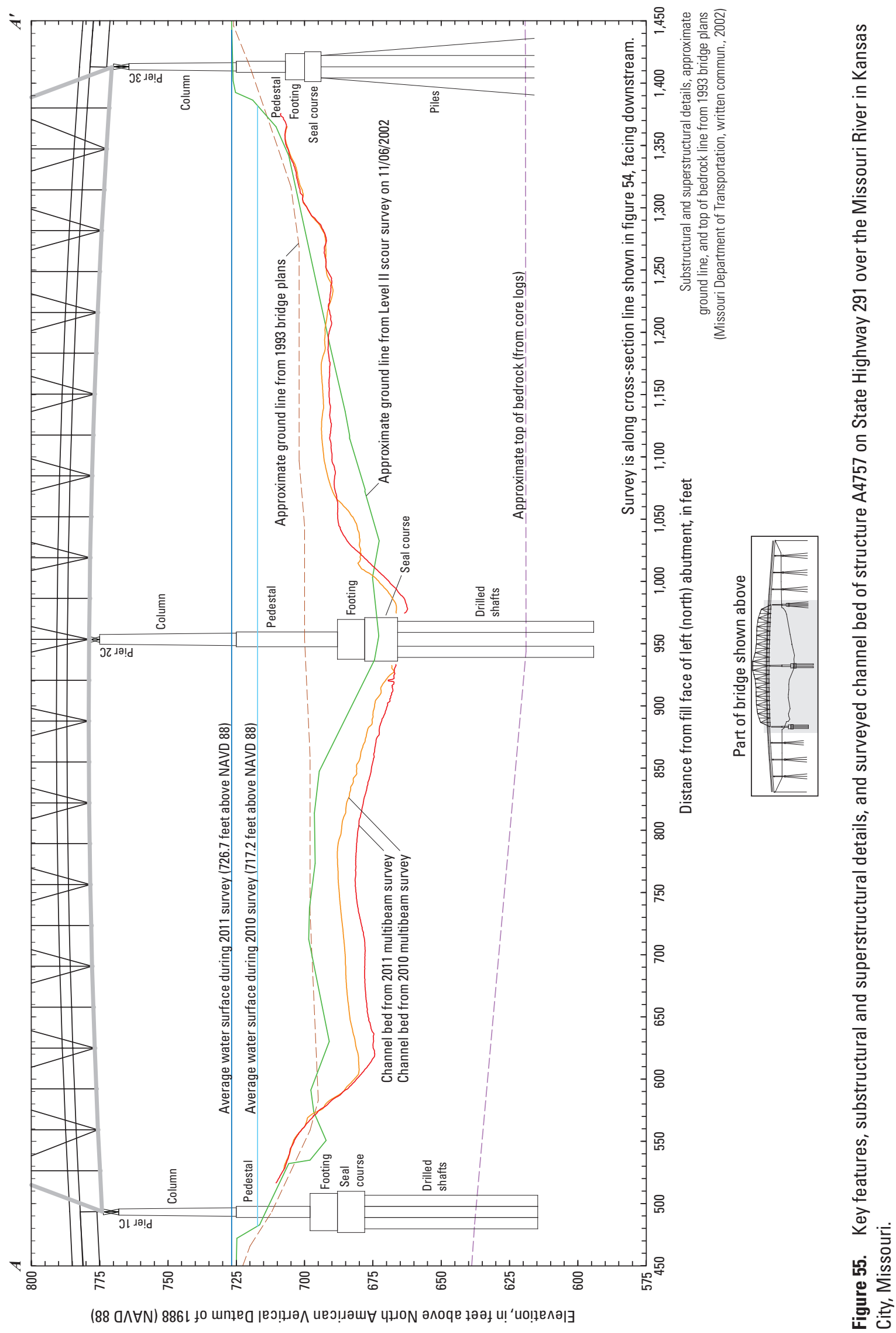




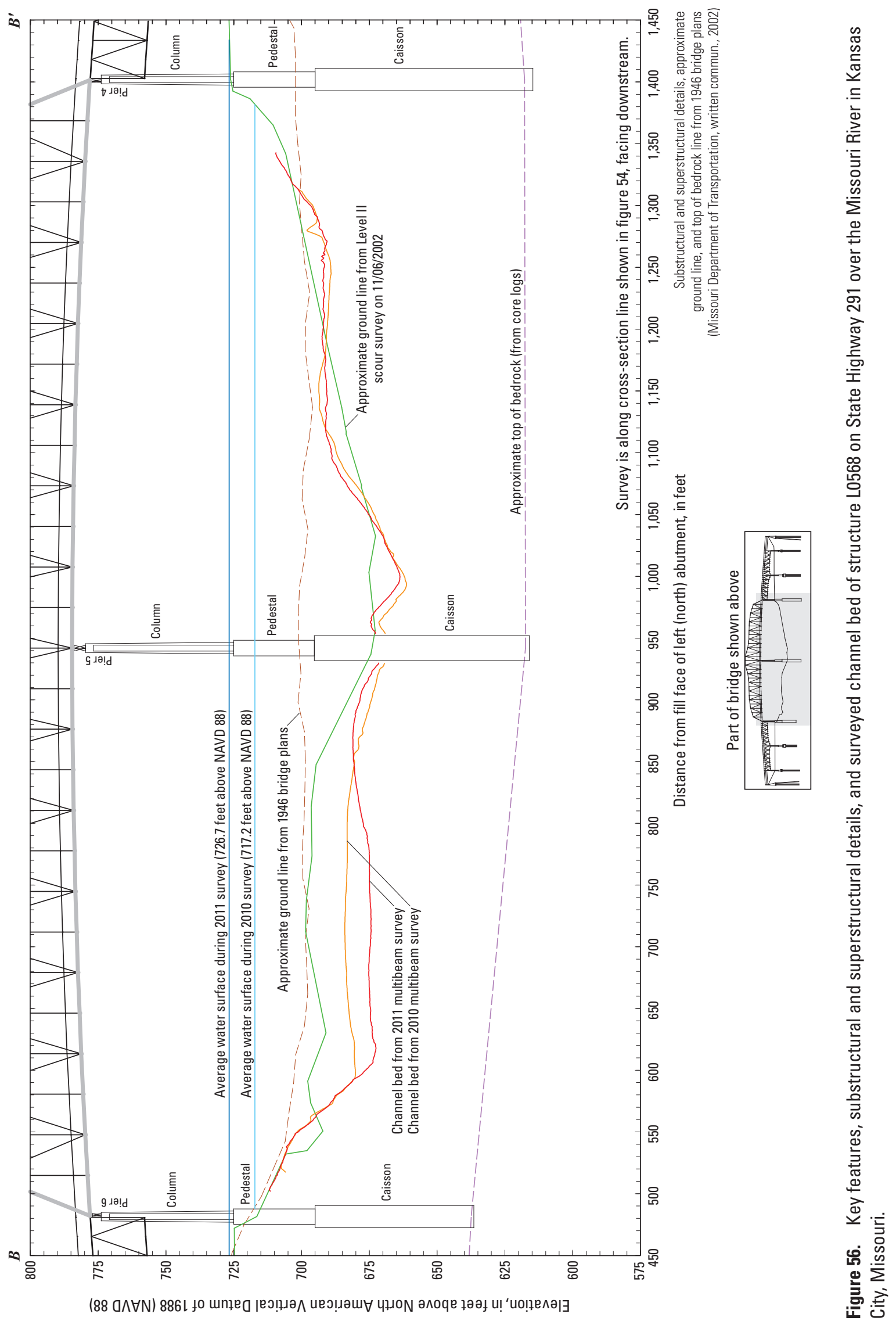




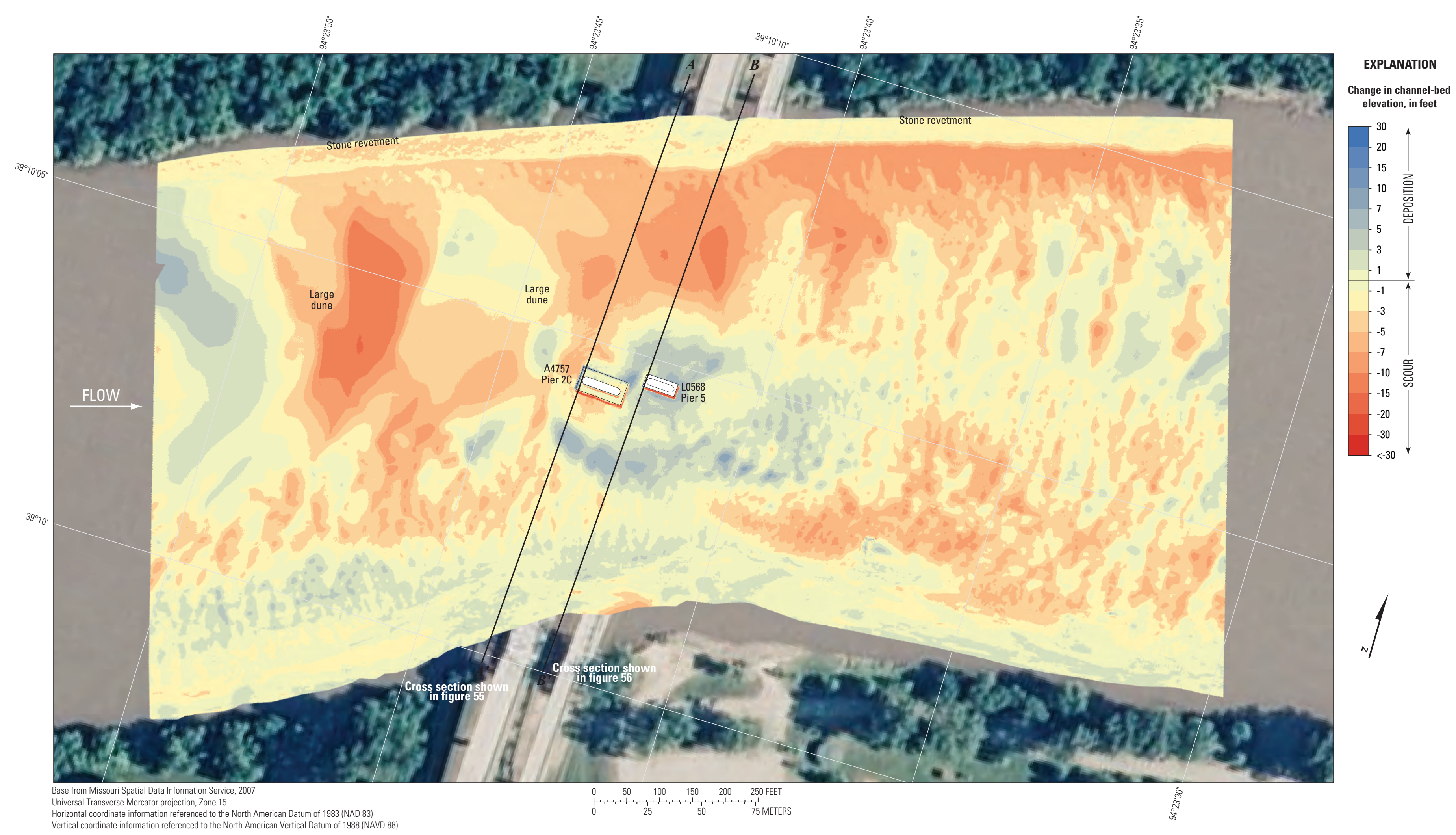

Figure 57. Difference between surfaces created from bathymetric surveys of the Missouri River channel in the vicinity of structures A4757 and L0568 on State Highway 291 in Kansas City, Missouri, on March 18, 2010 , and July 19, 2011. 


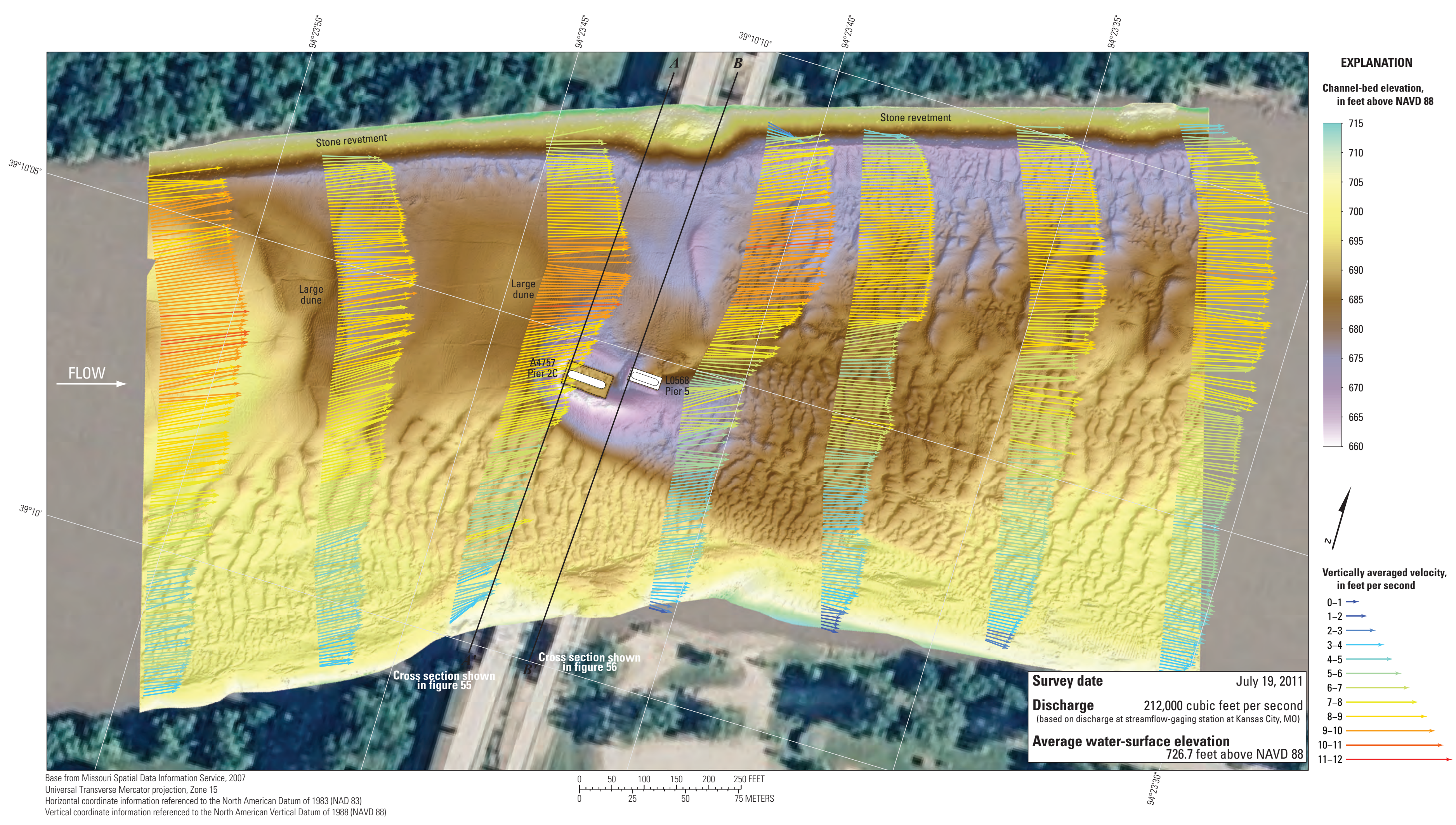

Figure 58. Bathymetry and vertically averaged velocities of the Missouri River channel in the vicinity of structures A4757 and L0568 on State Highway 291 in Kansas City, Missouri. 


\section{Between Kansas City and St. Louis}

There are nine unique highway crossings of the Missouri River between Kansas City and St. Louis (table 1; fig. 1). All of these crossings were surveyed during the 2011 summer flooding, and one crossing had previous bathymetric surveys.

\section{Structure A5664 on State Highway 13 at Lexington, Missouri}

Structure A5664 (site 14) on State Highway 13 crosses the Missouri River at RM 314.9 at Lexington, Missouri, east of Kansas City (fig. 1). The site was surveyed on July 20, 2011, and the average water-surface elevation of the river in the survey area, determined by the RTK GPS tide solution, was $693.9 \mathrm{ft}$ (table 5). Flow on the Missouri River was about $211,000 \mathrm{ft}^{3} / \mathrm{s}$ during the survey, according to the streamgage at Kansas City, Missouri (table 5).

The survey area was about 1,640 ft long and about $950 \mathrm{ft}$ wide, extending from bank to bank in the main channel (fig. 59). The upstream end of the survey area was about $670 \mathrm{ft}$ upstream from the centerline of structure A5664 (fig. 59), and piers 21 and 22 were in the water and away from the banks. The channel-bed elevations ranged from about 652 to $670 \mathrm{ft}$ for most of the surveyed area ( 5 to 95 percentile range of the bathymetric data), except in the vicinity of the spur dikes on the right (south) bank (fig. 59). A wide, shallow thalweg with medium dune features was present along the left (north) bank, and numerous medium and small dunes and ripples were present throughout the rest of the channel (fig. 59). Large scour holes were present downstream from the spur dikes on the right (south) side. Stone revetment was present on the left (north) bank throughout the reach (fig. 59).

The minor scour holes in the vicinity of both main channel piers 21 and 22 were difficult to discern from nearby dunes and ripples (fig. 59). The top of the footing for pier 21 was evident at the downstream end of the pier (fig. 59). Information from bridge plans indicates that piers 21 and 22 are founded on shafts drilled 28 to $50 \mathrm{ft}$ into bedrock, with about $49 \mathrm{ft}$ of bed material between the channel bottom and bedrock at pier 21 and about $27 \mathrm{ft}$ of material at pier 22 (fig. 60; table 8). The surveyed bed generally was similar to the original ground line from bridge plans (1999), with an area of 5 to $10 \mathrm{ft}$ of deposition near pier 22 (fig. 60).

The vertically averaged velocity vectors indicate mostly uniform flow throughout most of the channel, ranging from about 4 to $10 \mathrm{ft} / \mathrm{s}$ (fig. 61), except downstream from the spur dikes on the right (south) bank. Moderate turbulence was observed at several transects (fig. 61), likely as a result of flow disturbances caused by the spur dikes. The bridge piers were aligned with flow, with no evident turbulence downstream from either (fig. 61).

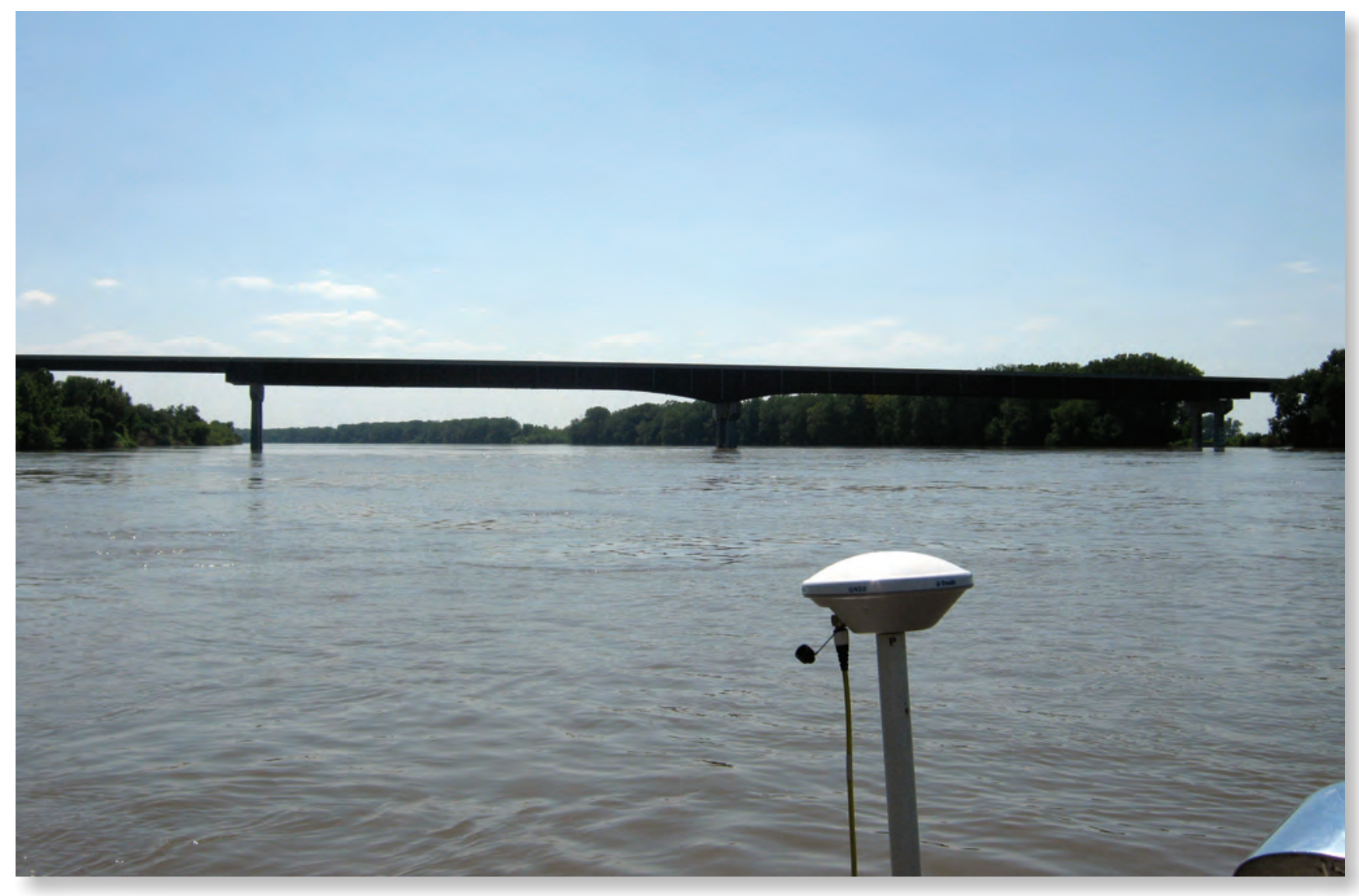

Structure A5664 on State Highway 13 at Lexington, Missouri. Photograph by Joseph Richards, USGS. 


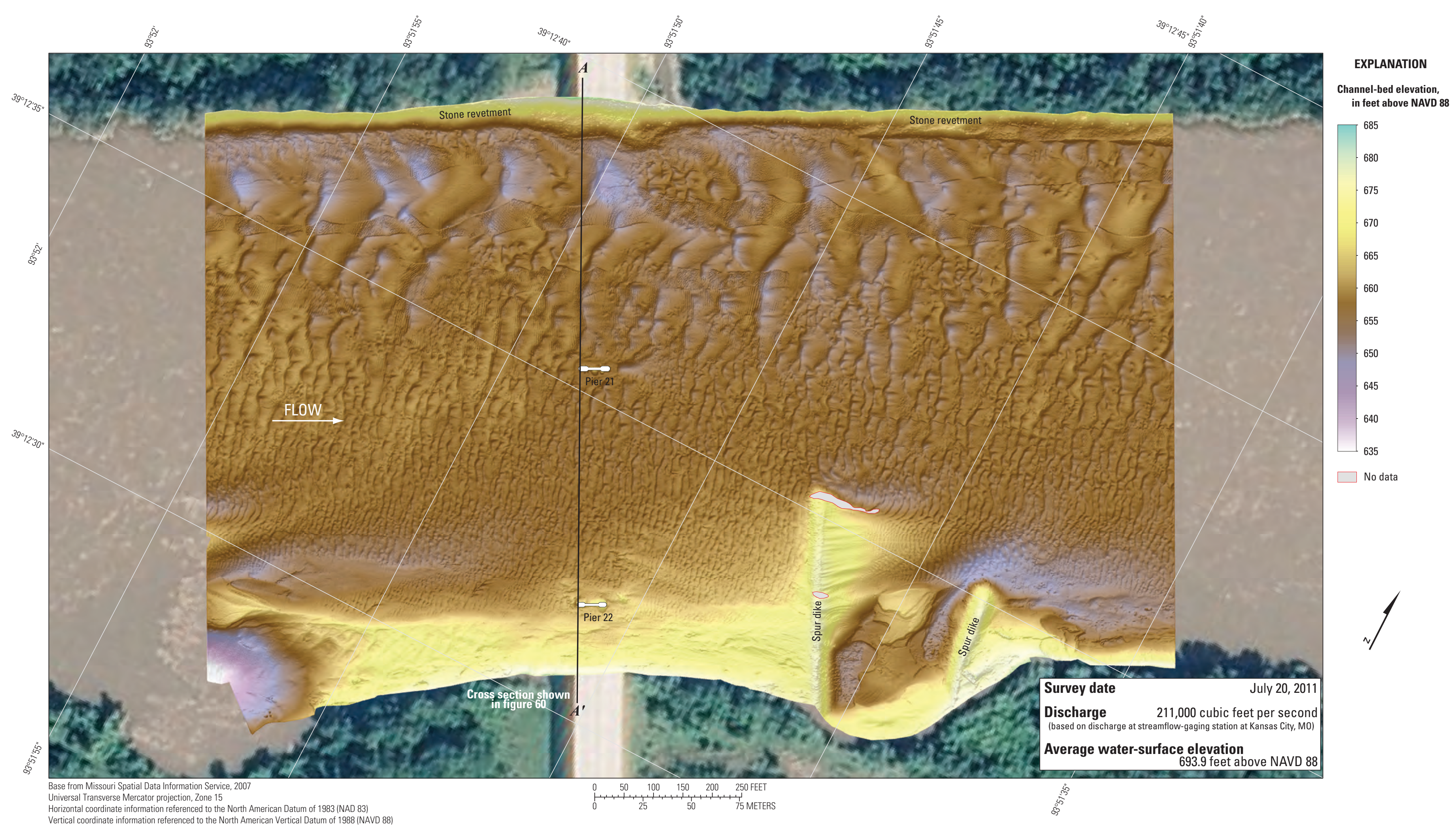

Figure 59. Bathymetric survey of the Missouri River channel in the vicinity of structure A5664 on State Highway 13 at Lexington, Missouri 


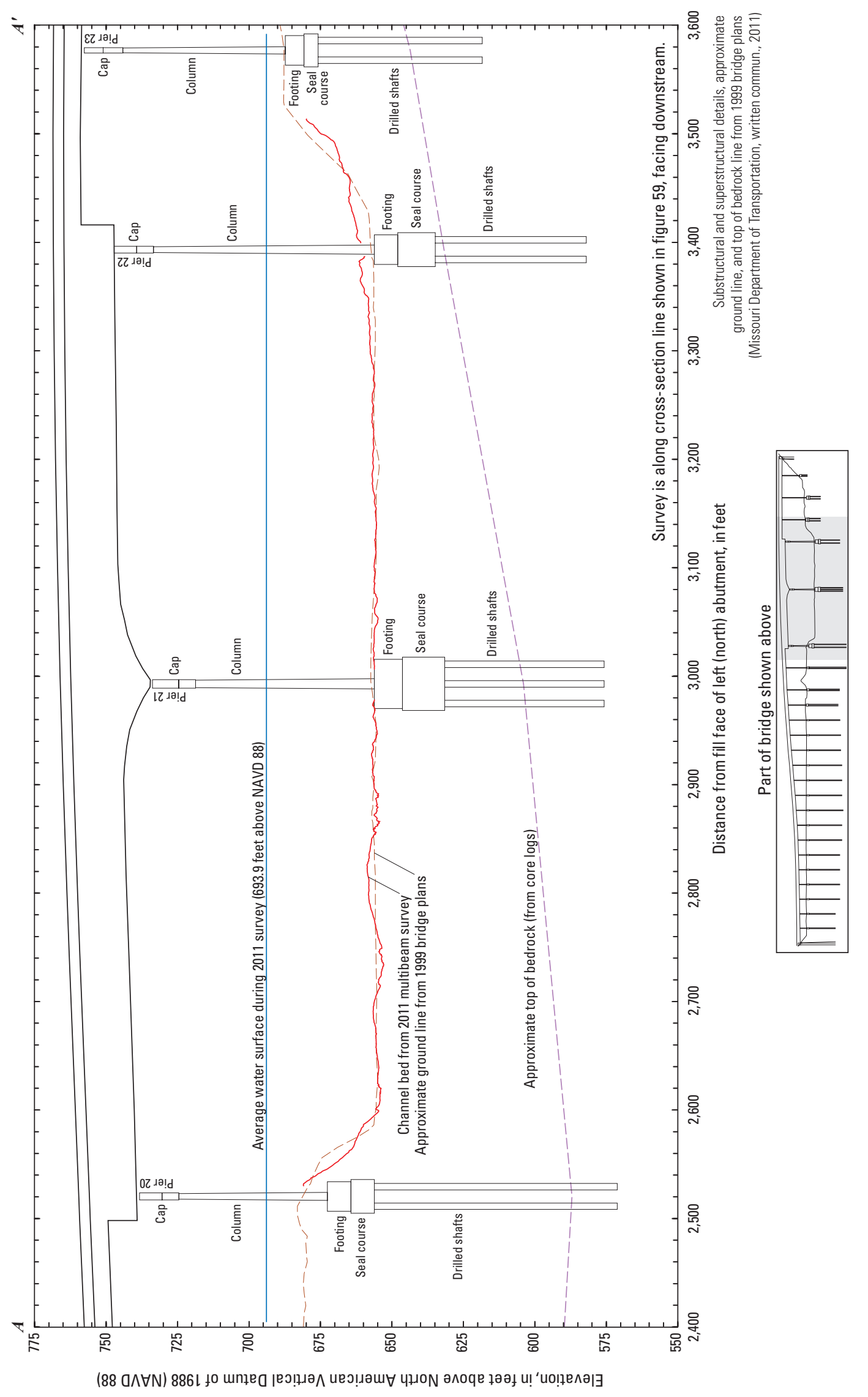

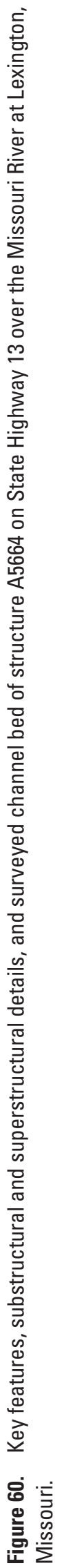




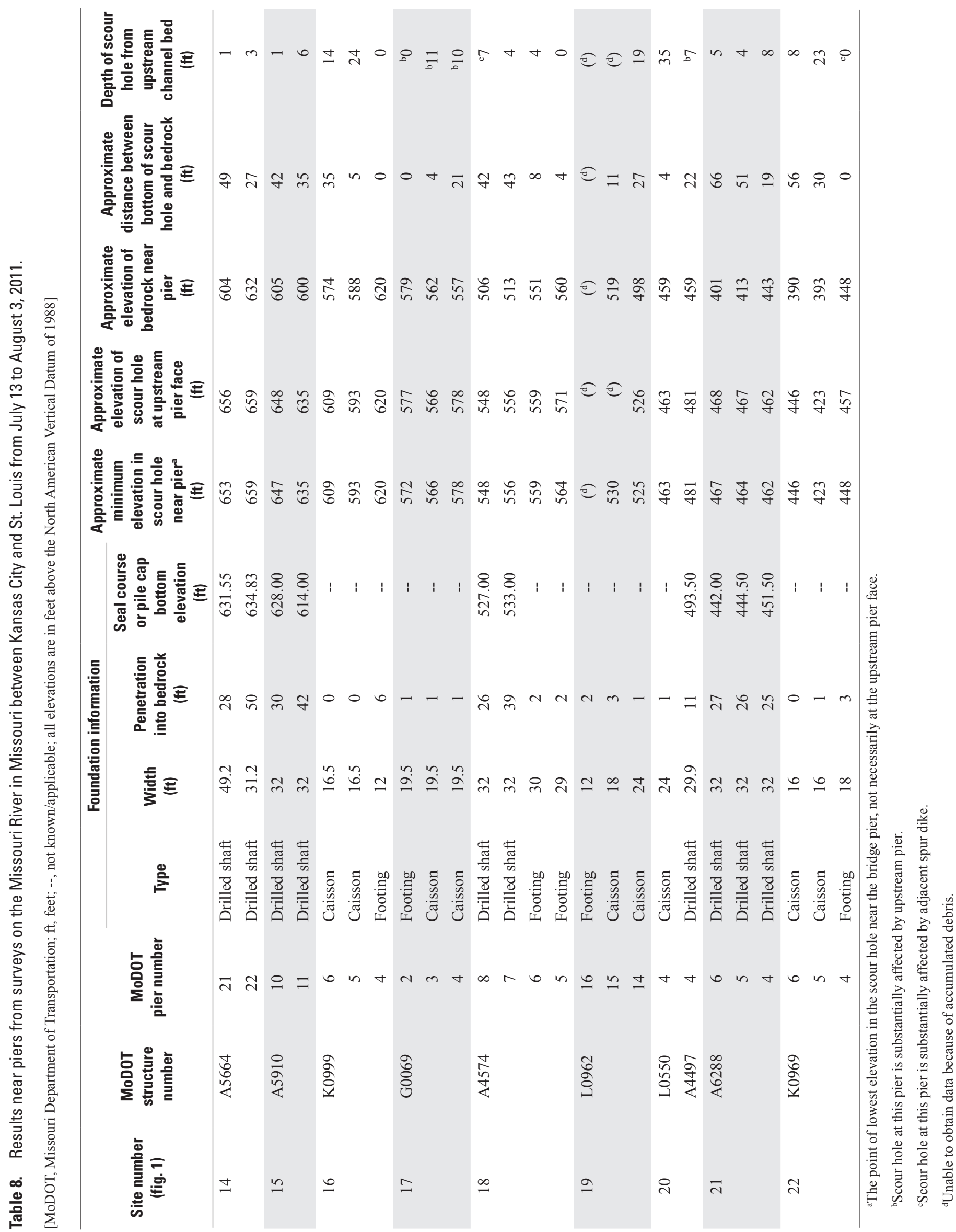




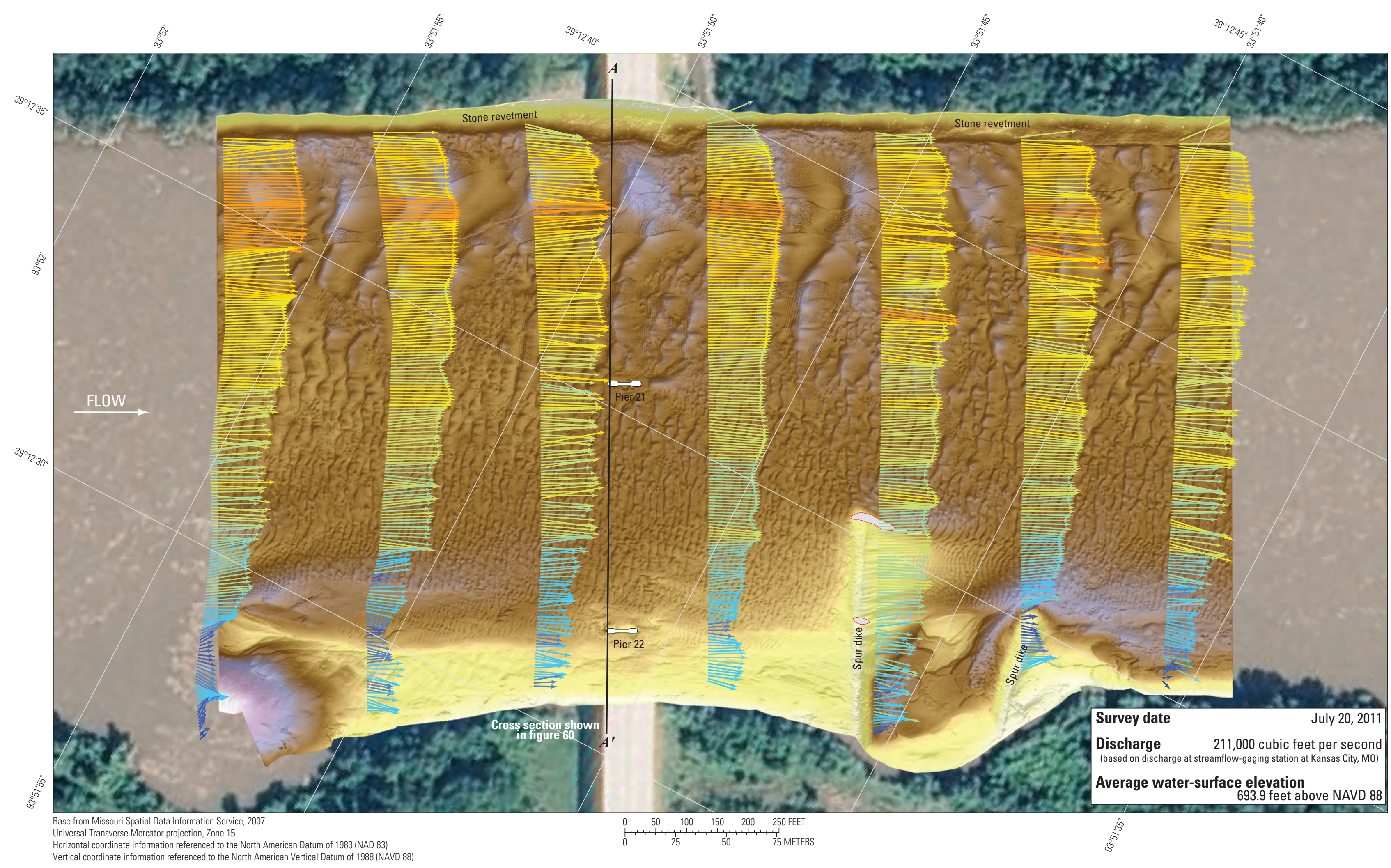

EXPLANATION Channel-bed elevation,
in feet above NAVD 88 685 


\section{Structure A5910 on U.S. Highway 24 at Waverly, Missouri}

Structure A5910 (site 15) on U.S. Highway 24 crosses the Missouri River at RM 293.2 at Waverly, Missouri, east of Lexington and Kansas City (fig. 1). The site was surveyed on July 21, 2011, and the average water-surface elevation of the river in the survey area, determined by the RTK GPS tide solution, was $674.3 \mathrm{ft}$ (table 8). Flow on the Missouri River was about $213,000 \mathrm{ft}^{3} / \mathrm{s}$ during the survey, according to the streamgage at Waverly, Missouri (table 8).

The survey area was about 1,640 ft long and about $1,020 \mathrm{ft}$ wide, extending from bank to bank in the main channel (fig. 62). The upstream end of the survey area was about $650 \mathrm{ft}$ upstream from the centerline of structure A5910 (fig. 62), and piers 10 and 11 were in the water and away from the banks. The channel-bed elevations ranged from about 632 to $653 \mathrm{ft}$ for most of the surveyed area (5 to 95 percentile range of the bathymetric data), except in the vicinity of the upstream spur dike on the left (north) bank (fig. 62). A deep thalweg on the right (south) bank on the upstream end of the surveyed area was about $20 \mathrm{ft}$ deeper than the channel bed in the middle of the channel (fig. 62). A series of large dune features were detected in the middle of the channel, and numerous medium and small dunes and ripples were present throughout the rest of the channel (fig. 62). Around the downstream spur dike on the left (north) side, the elevations were 20 to $25 \mathrm{ft}$ higher than elevations in the thalweg on the right side (fig. 62). Rock outcrops, stone revetment, and longitudinal spur dikes were present on the right (south) bank throughout the reach (fig. 62).

Minor scour holes were observed near the two piers in water. In the vicinity of main channel pier 11 (fig. 62), a minor scour hole had a minimum channel-bed elevation of about $635 \mathrm{ft}$ (table 8), about $21 \mathrm{ft}$ above the elevation of the bottom of the pier seal course of $614.00 \mathrm{ft}$ (fig. 63; table 8). The minor scour hole near pier 10 was difficult to discern from nearby small dunes and ripples (figs. 62, 63). Information from bridge plans indicates that piers 10 and 11 are founded on shafts drilled 30 to $42 \mathrm{ft}$ into bedrock, with about $42 \mathrm{ft}$ of bed material between the bottom of the scour hole and bedrock at pier 10 and about $35 \mathrm{ft}$ of material at pier 11 (fig. 63; table 8). The surveyed bed generally was similar to the original ground line from bridge plans (1999), with localized areas of scour and deposition across the section (fig. 63).

The vertically averaged velocity vectors indicate mostly uniform flow throughout most of the channel, with velocities ranging from about 4 to $11 \mathrm{ft} / \mathrm{s}$ (fig. 64), except downstream from the upstream spur dike on the left (north) bank. Moderate turbulence was observed in the channel thalweg at and downstream from the bridge (fig. 64), and local flow reversal was observed downstream from the upstream spur dike on the left (north) bank (fig. 64). The bridge piers were aligned with flow, with no evident turbulence downstream from either pier (fig. 64).

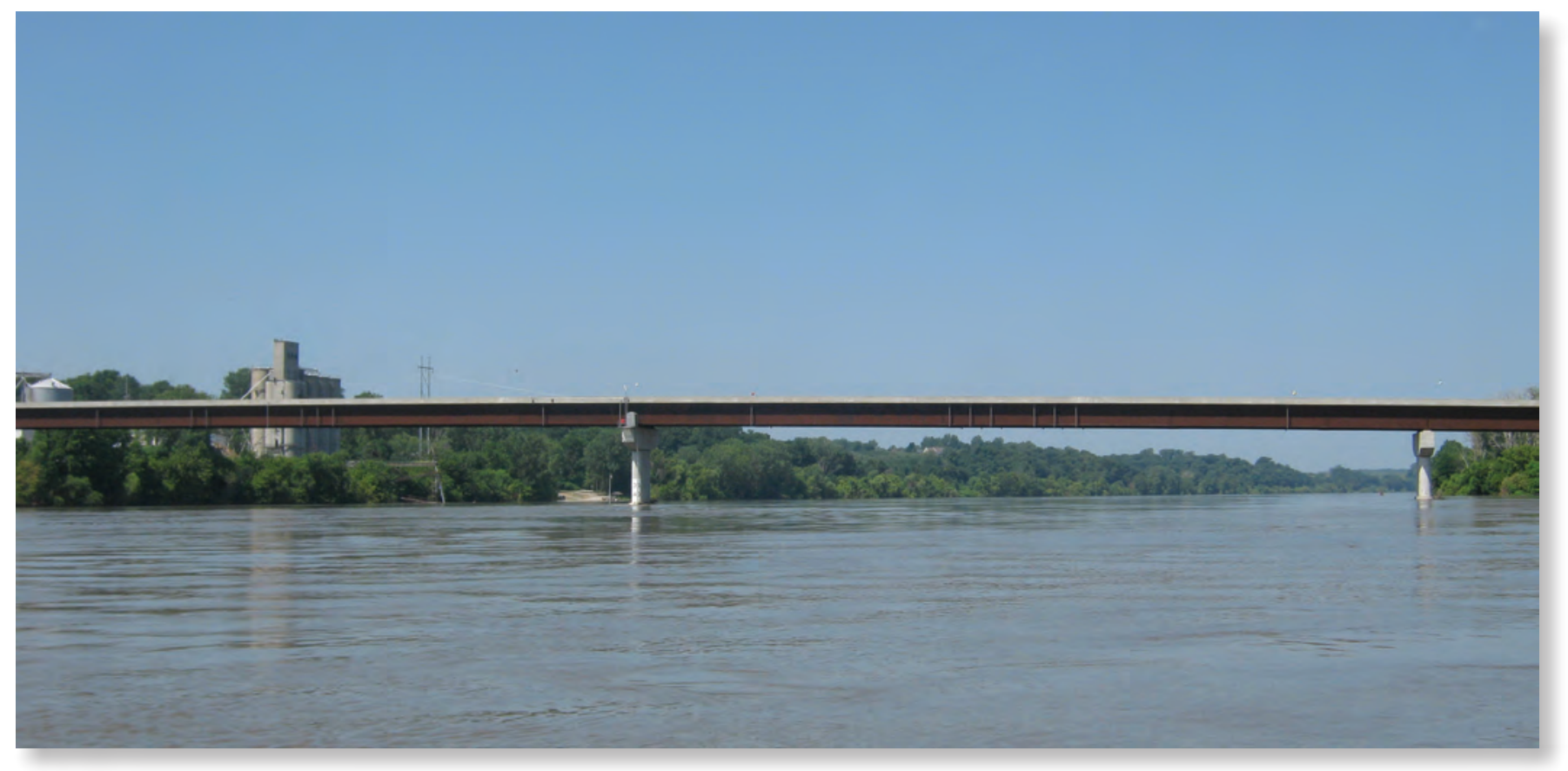

Structure A5910 on U.S. Highway 24 at Waverly, Missouri. Photograph by Joseph Richards, USGS. 


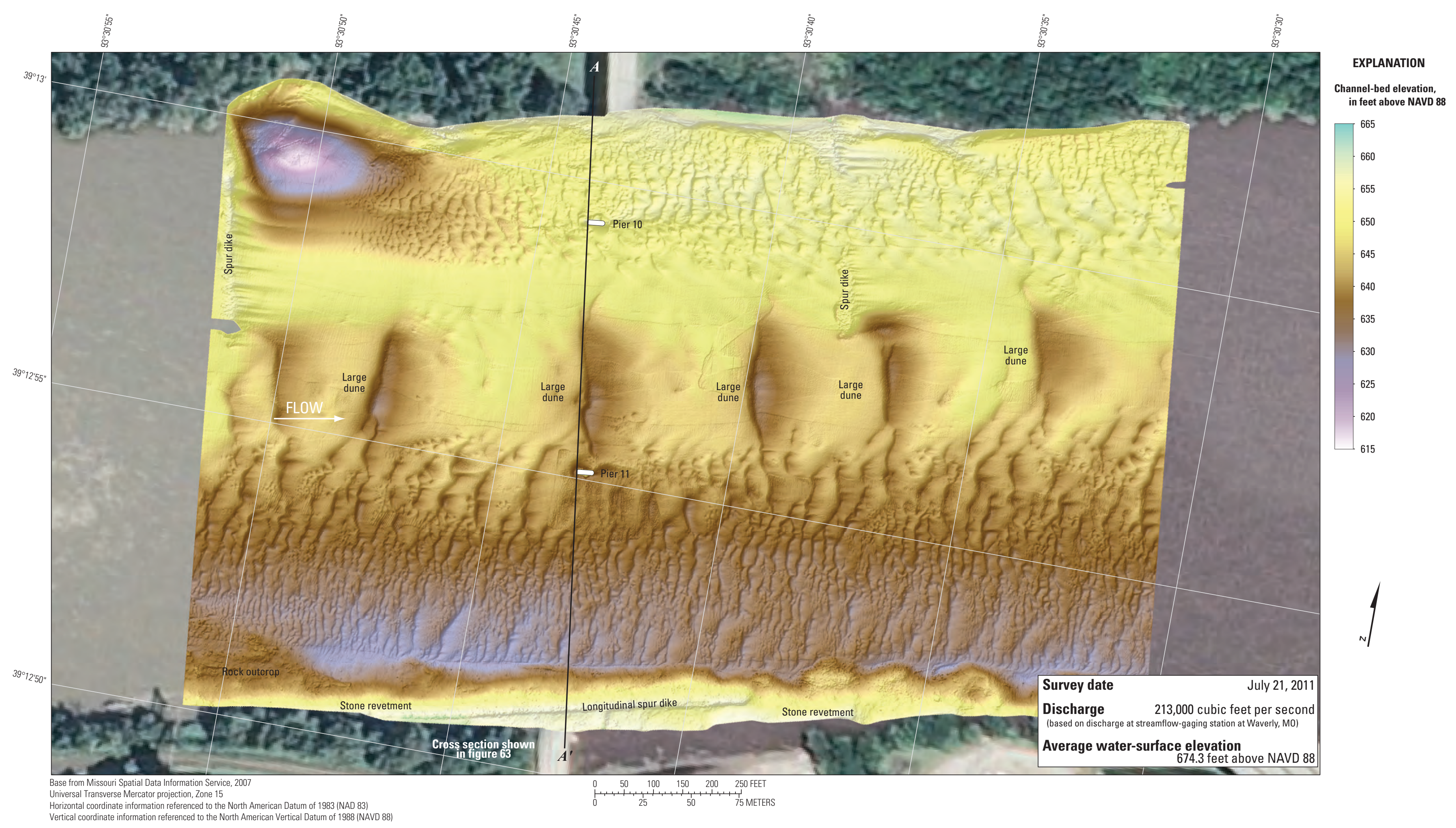

Figure 62. Bathymetric survey of the Missouri River channel in the vicinity of structure A5910 on U.S. Highway 24 at Waverly, Missouri. 


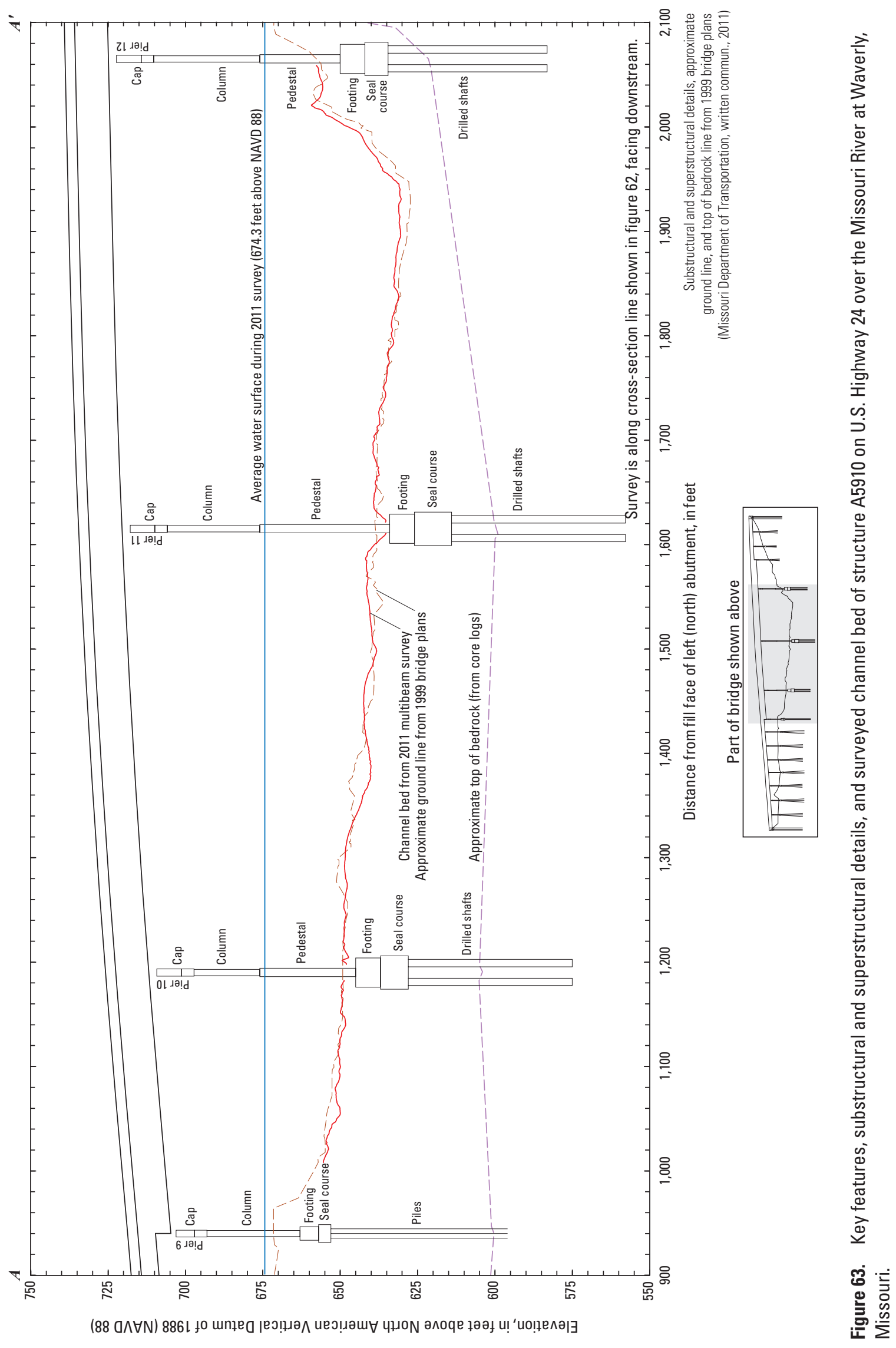




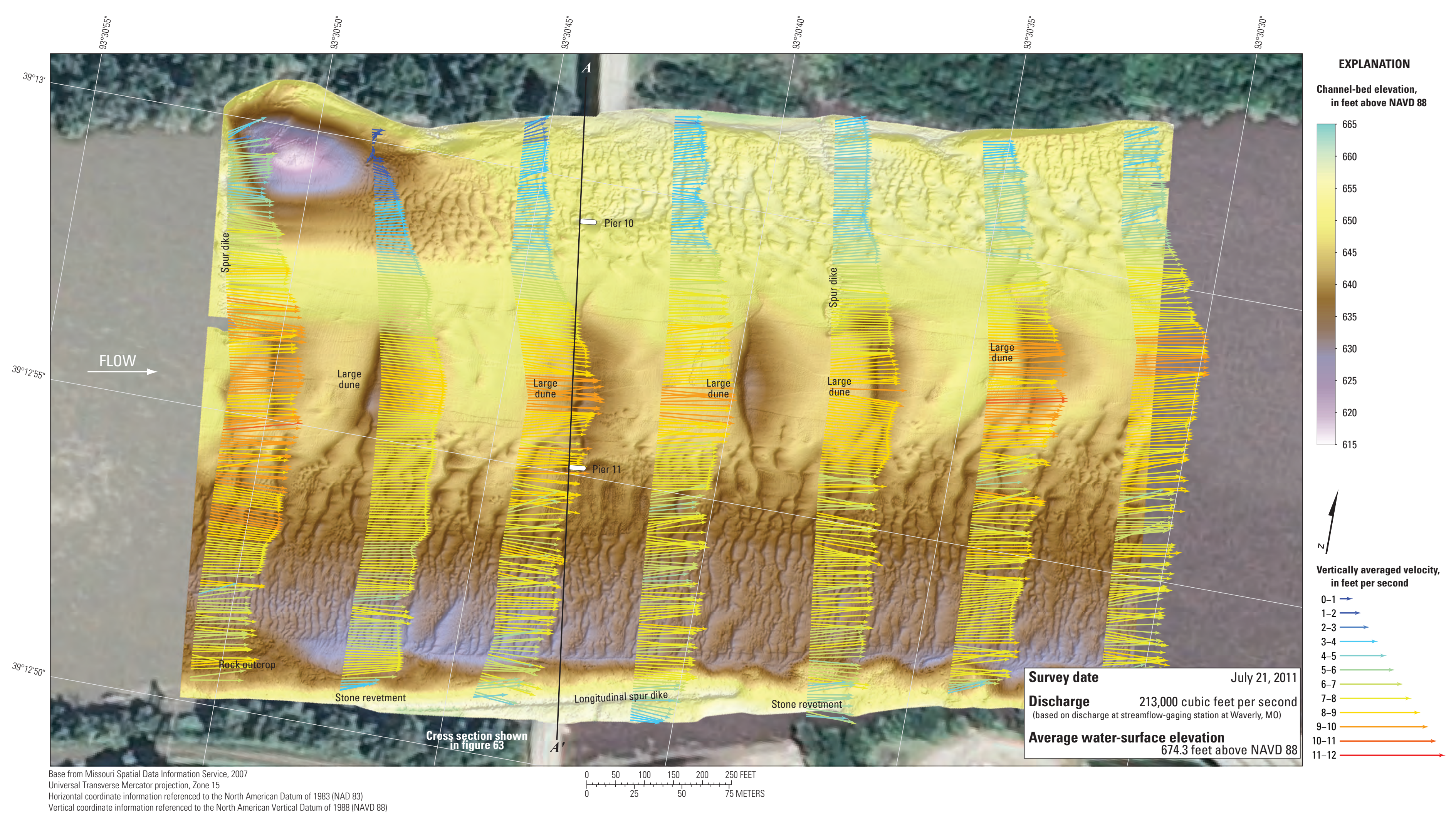

Figure 64. Bathymetry and vertically averaged velocities of the Missouri River channel in the vicinity of structure A5910 on U.S. Highway 24 at Waverly, Missouri. 


\section{Structure K0999 on State Highway 41 at Miami, Missouri}

Structure K0999 (site 16) on State Highway 41 crosses the Missouri River at RM 262.6 at Miami, Missouri, east of Waverly and Kansas City (fig. 1). The site was surveyed on July 21, 2011, and the average water-surface elevation of the river in the survey area, determined by the RTK GPS tide solution, was $648.3 \mathrm{ft}$ (table 5). Flow on the Missouri River was about $213,000 \mathrm{ft}^{3} / \mathrm{s}$ during the survey, according to the streamgage at Waverly, Missouri (table 5).

The survey area was about 1,640 ft long, and varied from about $1,330 \mathrm{ft}$ wide at the upstream end to about $1,060 \mathrm{ft}$ wide near the downstream end, extending from bank to bank in the main channel (fig. 65). The upstream end of the survey area was about $625 \mathrm{ft}$ upstream from the centerline of structure K0999, and piers 4 through 6 were in the water and away from the banks (fig. 65). The channel-bed elevations ranged from about 607 to $628 \mathrm{ft}$ for most of the surveyed area (5 to 95 percentile range of the bathymetric data), except in the channel thalweg along the right (south) bank, which reached a minimum channel-bed elevation of about $600 \mathrm{ft}$ (fig. 65; table 5). The thalweg was about 20 to $25 \mathrm{ft}$ deeper than the channel bed on the left (north) side (fig. 65). A substantial area of exposed bedrock was present on the right (south) bank, along with longitudinal spur dikes (fig. 65). A few large dune features also were detected in the thalweg along the interface with the exposed bedrock, and numerous medium and small dunes and ripples were present throughout the rest of the channel (fig. 65).

Scour holes were observed near two of the three piers in water. In the vicinity of pier 6 (fig. 65), a moderate scour hole had a minimum channel-bed elevation of about $609 \mathrm{ft}$ (table 8), about $14 \mathrm{ft}$ below the average channel bed upstream from the pier (figs. 65, 66; table 8). A substantial scour hole was observed in the vicinity of pier 5 , with a minimum channel-bed elevation of about $593 \mathrm{ft}$ (figs. 65, 66; table 8). Information from bridge plans indicates that piers 5 and 6 are caissons founded on bedrock, with about $35 \mathrm{ft}$ of bed material between the bottom of the scour hole and bedrock at pier 6 , but only about $5 \mathrm{ft}$ of material at pier 5 (fig. 66; table 8). No scour hole was observed near pier 4 (fig. 65), which is founded on a footing on bedrock according to bridge plans (fig. 66; table 8). The surveyed bed generally was similar to the ground line from the Level II bridge scour assessment in 2002 except near the piers, with about 5 to $10 \mathrm{ft}$ of deposition between piers 5 and 6 and between pier 5 and the channel thalweg, and about $15 \mathrm{ft}$ of scour near the left bank (fig. 66). The approximate top of bedrock line from bridge plans confirms that the fluvial material near the right bank has washed away, exposing the bedrock along the thalweg (fig. 66). In modern construction, bridge substructural elements usually are pinned or socketed to bedrock (American Association of State Highway Transportation Officials, 2012; Brown and others, 2010), but full exposure of usually buried substructural elements warrants special consideration and observation.

The vertically averaged velocity vectors indicate mostly uniform flow throughout most of the channel, with velocities ranging from about 4 to $10 \mathrm{ft} / \mathrm{s}$ (fig. 67). Velocities were higher in the thalweg, and lower in the shallow area on the left (north) side of the channel (fig. 67). Moderate turbulence was observed at various locations in the channel thalweg (fig. 67), and local velocity minima were observed downstream from the spur dike on the left (north) bank and behind the longitudinal spur dike on the right (south) bank (fig. 67). The bridge piers were aligned with flow, with no evident turbulence downstream from any pier (fig. 67).

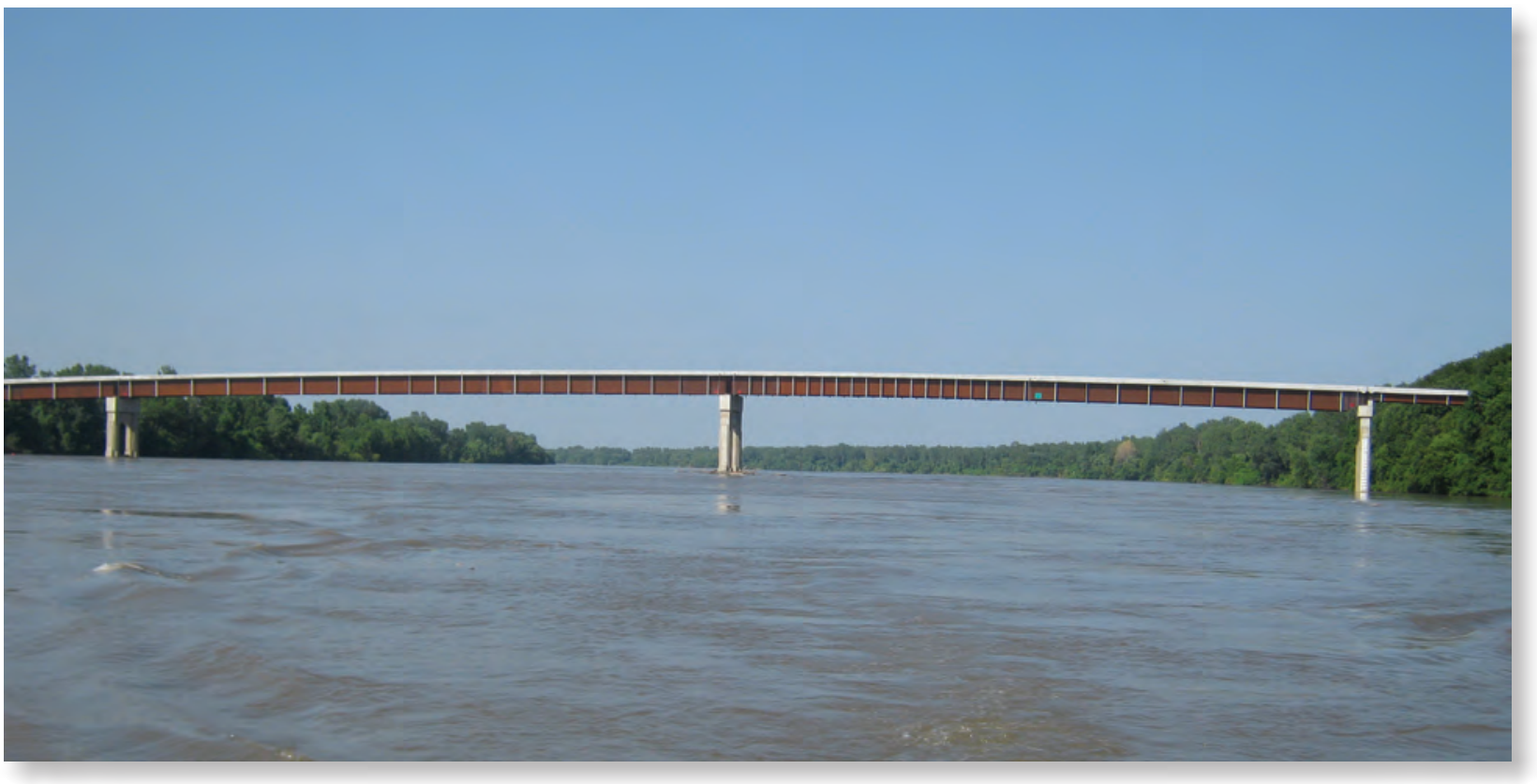

Structure K0999 on State Highway 41 at Miami, Missouri. Photograph by Joseph Richards, USGS. 


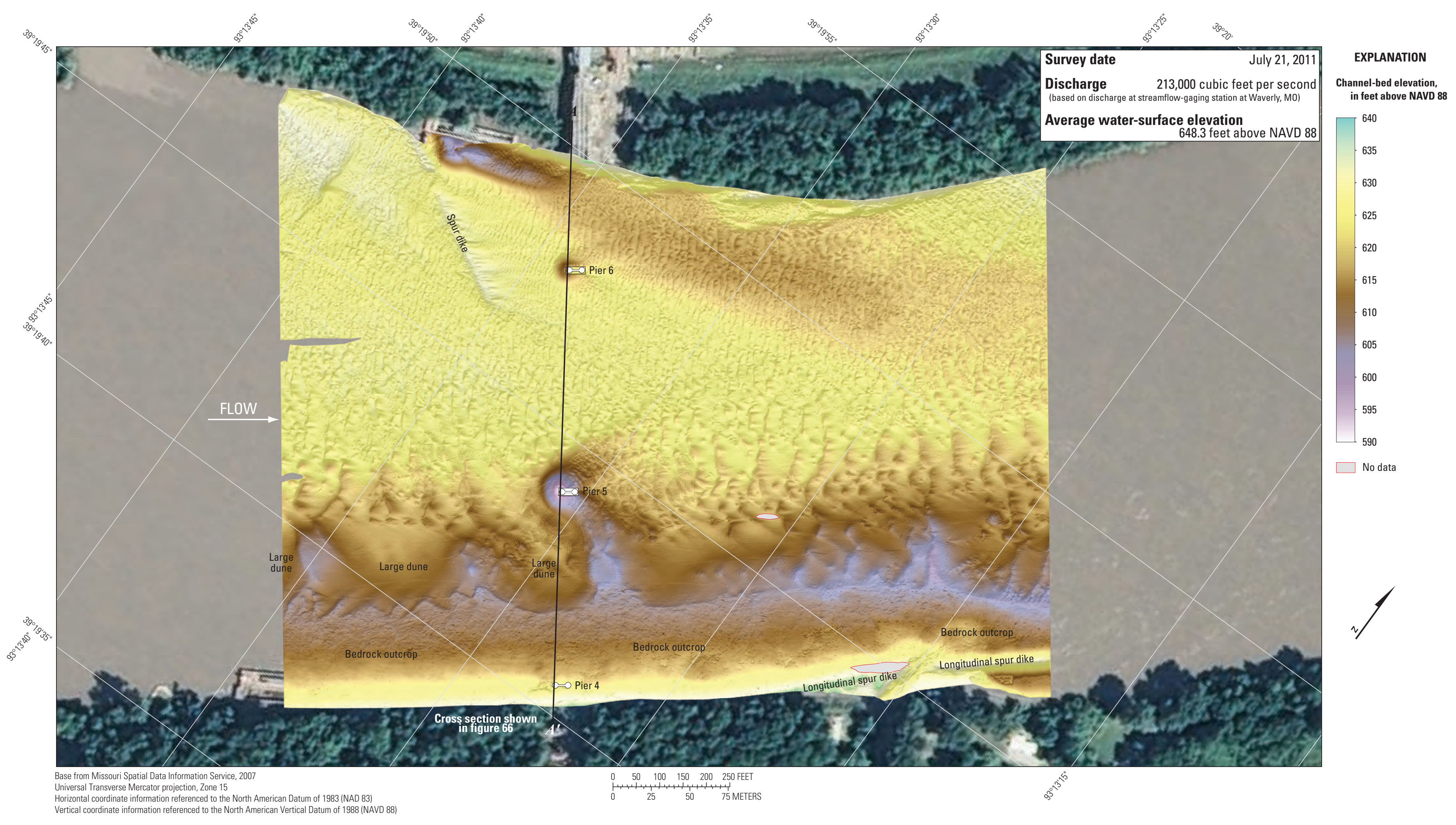

Figure 65. Bathymetric survey of the Missouri River channel in the vicinity of structure K0999 on State Highway 41 at Miami, Missouri. 


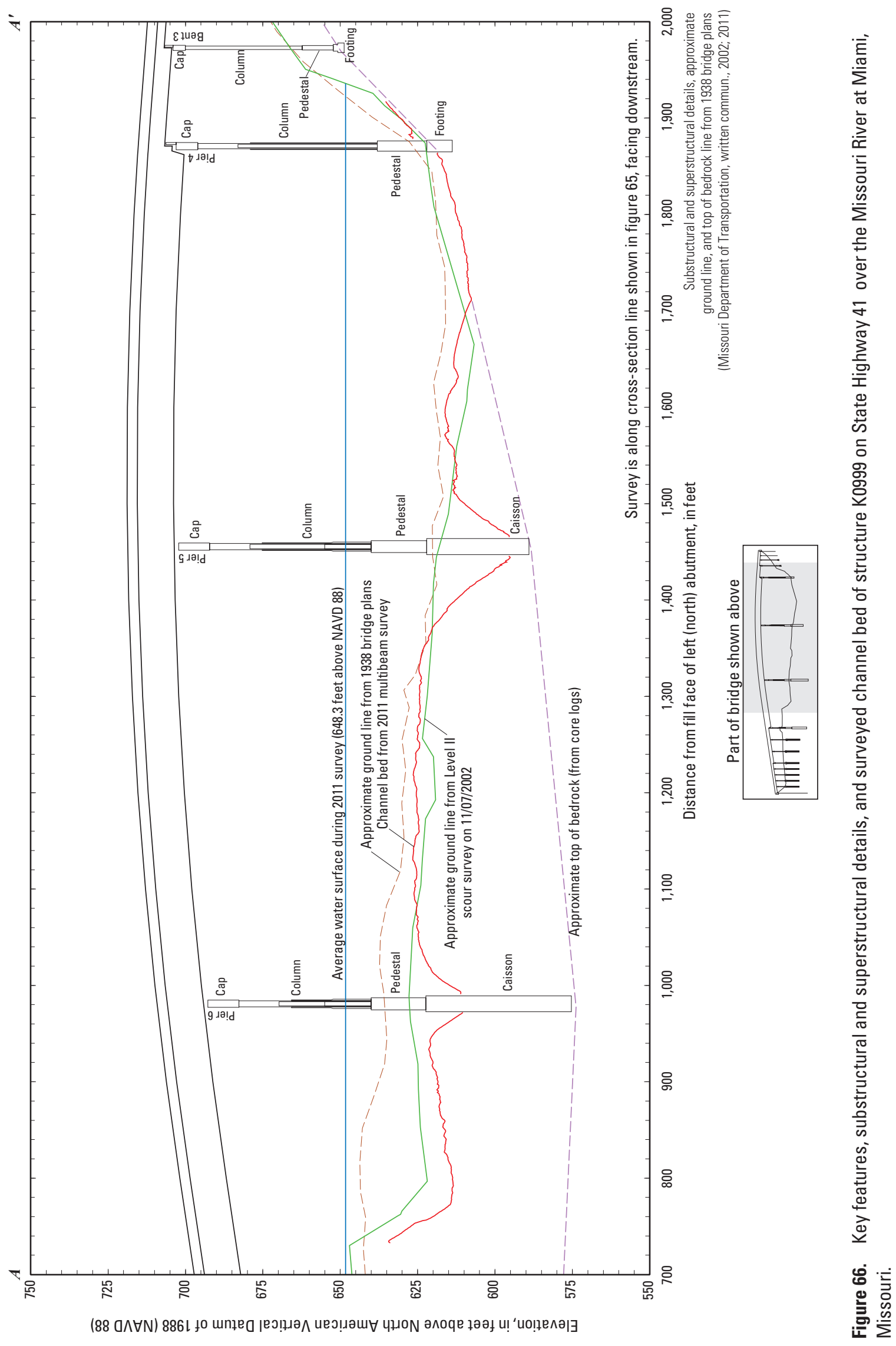




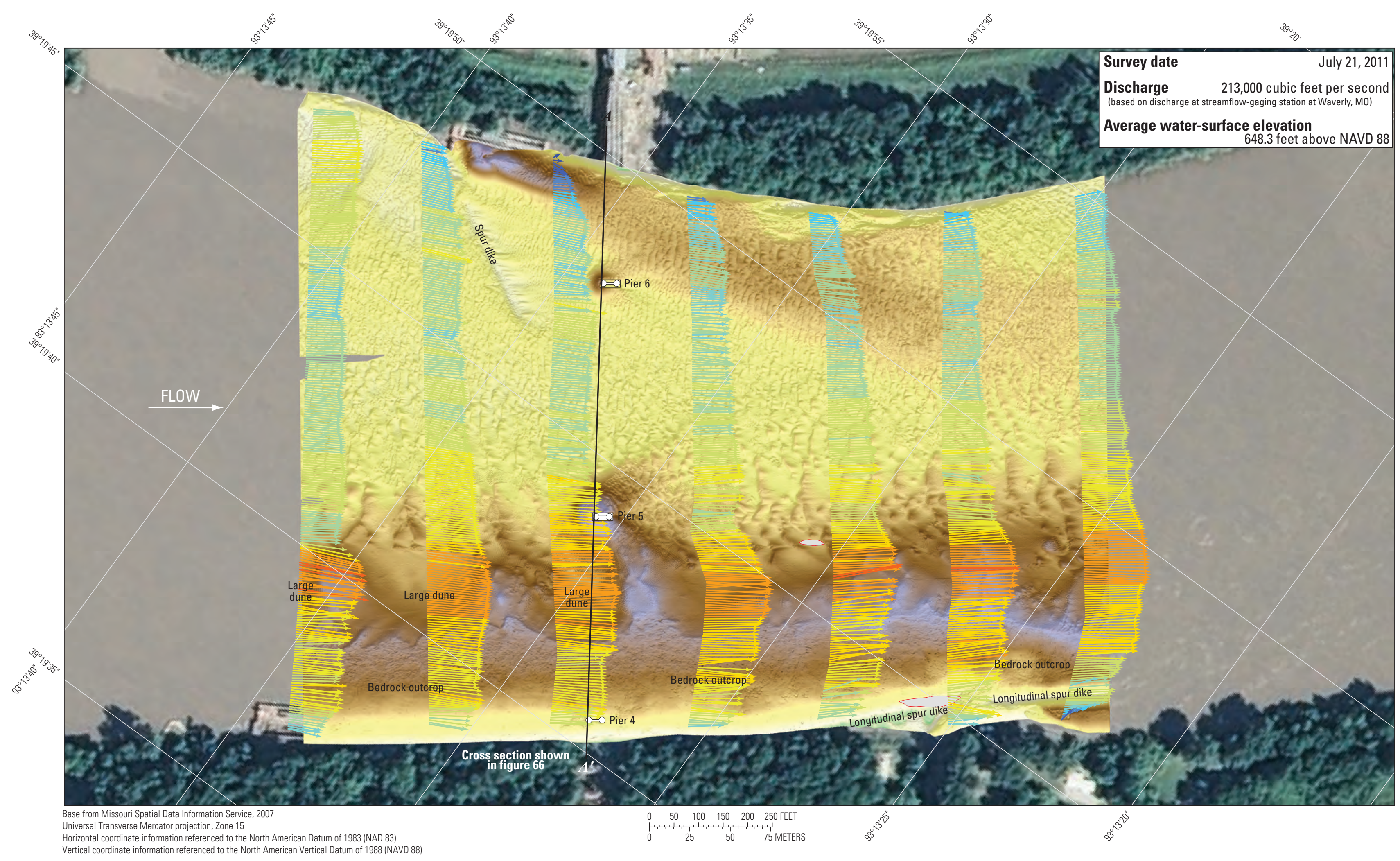

EXPLANATION

Channel-bed elevation, $\square^{640}$

635

630

625

620

615

610

605

600

Vertically averaged velocity, $\underset{0-1 \rightarrow}{\text { in feet per }}$

$\stackrel{1-2 \rightarrow}{0}$

$2-3 \longrightarrow$

$3-4$

$\underset{\substack{5.6 \\ 6 \rightarrow 7}}{6.7}$

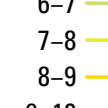

$8-9$
$9-10$
$10-11$

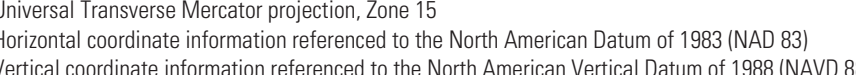

Figure 67. Bathymetry and vertically averaged velocities of the Missouri River channel in the vicinity of structure K0999 on State Highway 41 at Miami, Missouri. 


\section{Structure G0069 on State Highway 240 at Glasgow, Missouri}

Structure G0069 (site 17) on State Highway 240 crosses the Missouri River at RM 226.3 at Glasgow, Missouri, southeast of Miami and about halfway between Kansas City and St. Louis (fig. 1). The site was surveyed on July 22, 2011, and the average water-surface elevation of the river in the survey area, determined by the RTK GPS tide solution, was $615.7 \mathrm{ft}$ (table 5). Flow on the Missouri River was about 214,000 $\mathrm{ft}^{3} / \mathrm{s}$ during the survey, according to the streamgage at Glasgow, Missouri (table 5).

The survey area was about 1,640 ft long, and varied from about $885 \mathrm{ft}$ wide at the upstream end to about 1,060 ft wide near the downstream end, extending from bank to bank in the main channel (fig. 68). The upstream end of the survey area was about $590 \mathrm{ft}$ upstream from the centerline of structure G0069, and piers 2, 3, and 4 were in the water and away from the banks (fig. 68). Structure G0069 is immediately downstream from a railroad bridge (fig. 68). The channel-bed elevations ranged from about 570 to $591 \mathrm{ft}$ for most of the surveyed area ( 5 to 95 percentile range of the bathymetric data), except near the piers and the left (east) bank in the downstream reach (fig. 68; table 5). A poorly defined thalweg along the left (east) bank was constrained by a substantial area of exposed bedrock in the upstream reach, but was about 20 to $25 \mathrm{ft}$ deeper than the channel bed on the right (west) side in the downstream reach (fig. 68). Several small spur dikes were present on the right (west) bank, along with a sunken barge (fig. 68). A few large dune features were detected in the middle of the channel, near the interface of the thalweg with the exposed bedrock, and numerous medium and small dunes and ripples were present throughout the rest of the channel (fig. 68).

No scour hole was observed near pier 2 (fig. 68), which is founded on a footing on bedrock according to bridge plans (fig. 69; table 8); however, a point cloud visualization of the multibeam depth points obtained during the survey near pier 2 indicates the magnitude of the exposure of the bridge and railroad bridge piers (fig. 70). It was difficult to determine from the multibeam depth points if the footing of pier 2 was undermined, because of sonic "ringing" that occurs near perpendicular faces such as that of the bedrock and the side of the footing. The ground line from the bathymetric survey indicated that the right (west) side of the footing may indeed be undermined, but the details of the foundation of the footing of pier 2 in the bridge plans for structure G0069 are not sufficient to tell if it was entrenched in the bedrock in any way, particularly if the top of the bedrock was not level (figs. 68, 69). In modern construction, bridge substructural elements usually are pinned or socketed to bedrock (American Association of State Highway Transportation Officials, 2012; Brown and others, 2010), but full exposure of usually buried substructural elements warrants special consideration and observation, particularly at an older bridge such as structure G0069.

Scour holes were observed near main channel piers 3 and 4 . In the vicinity of main channel pier 3 (fig. 68), a substantial scour hole had a minimum channel-bed elevation of about $566 \mathrm{ft}$ (table 8), about $11 \mathrm{ft}$ below the average channel bed immediately upstream from the pier (figs. 68, 69; table 8). A moderate scour hole was observed in the vicinity of main channel pier 4 , with a minimum channel-bed elevation of about $578 \mathrm{ft}$ (figs. 68, 69; table 8). Information from bridge plans indicates that piers 3 and 4 are caissons founded on bedrock, with only about $4 \mathrm{ft}$ of bed material between the bottom of the scour hole and bedrock at pier 3 , and about $21 \mathrm{ft}$ of material at pier 4 (fig. 69; table 8). The scour observed near all of the highway bridge piers was substantially affected by the upstream railroad bridge piers. The surveyed bed generally was similar to the ground line from the Level II bridge scour assessment in 2002, with about 5 to $10 \mathrm{ft}$ of scour near pier 2, and about 5 to $10 \mathrm{ft}$ of deposition between piers 2 and 3 and between piers 3 and 4 (fig. 69). The approximate top of bedrock line from bridge plans confirms that the fluvial material near the left bank has washed away, exposing the bedrock along the thalweg (fig. 69).

The vertically averaged velocity vectors indicate mostly uniform flow in two of the transects, but moderate turbulence throughout most of the channel, with velocities ranging from about 4 to $11 \mathrm{ft} / \mathrm{s}$ (fig. 71). Velocities were higher in the thalweg, and lower in the shallow area on the right (west) side of the channel (fig. 71). The turbulence observed at various places in the channel (fig. 71) likely was caused by a combination of the substantial bend in the channel immediately upstream from the surveyed reach and the rapidly changing channel bed along the thalweg, as well as local disturbances from the piers and spur dikes in the reach.

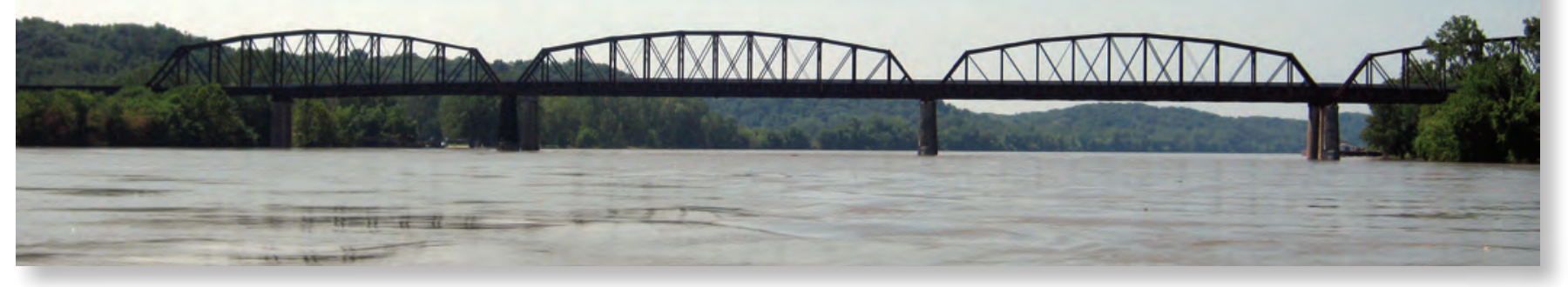

Structure G0069 on State Highway 240 at Glasgow, Missouri. The Glasgow railroad bridge is in the foreground. Photograph by Joseph Richards, USGS. 


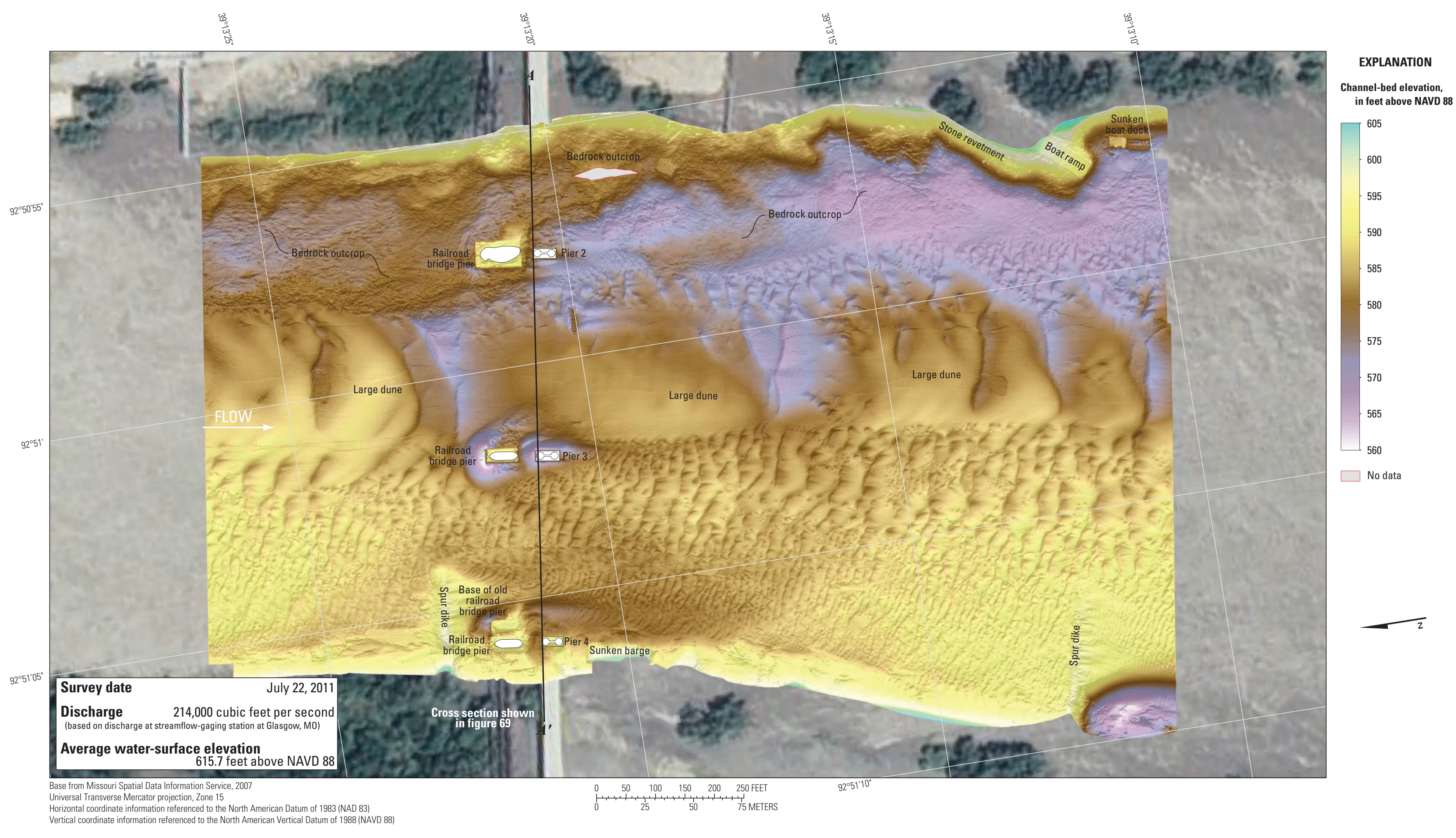

Figure 68. Bathymetric survey of the Missouri River channel in the vicinity of structure G0069 on State Highway 240 at Glasgow, Missouri 


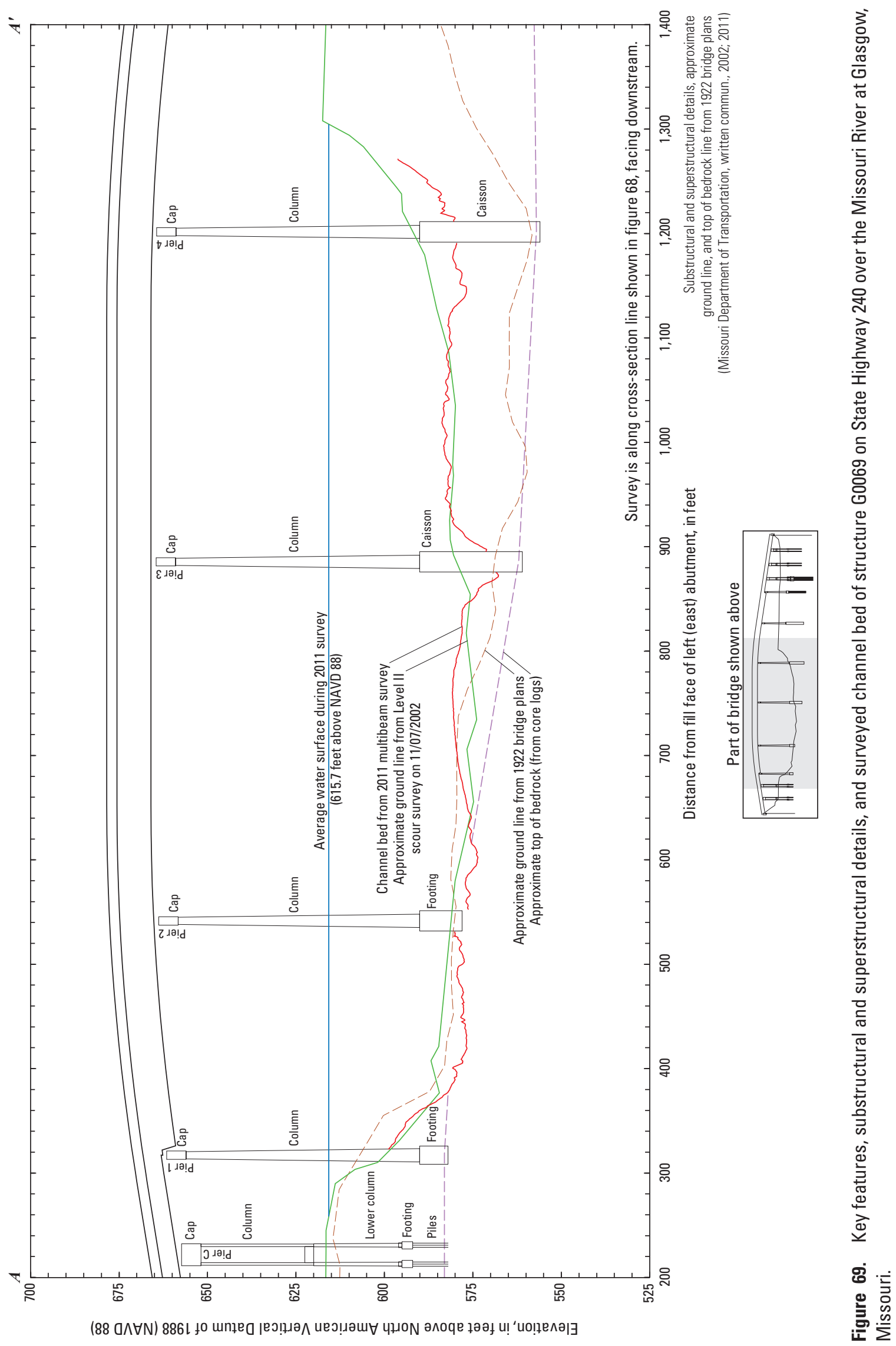




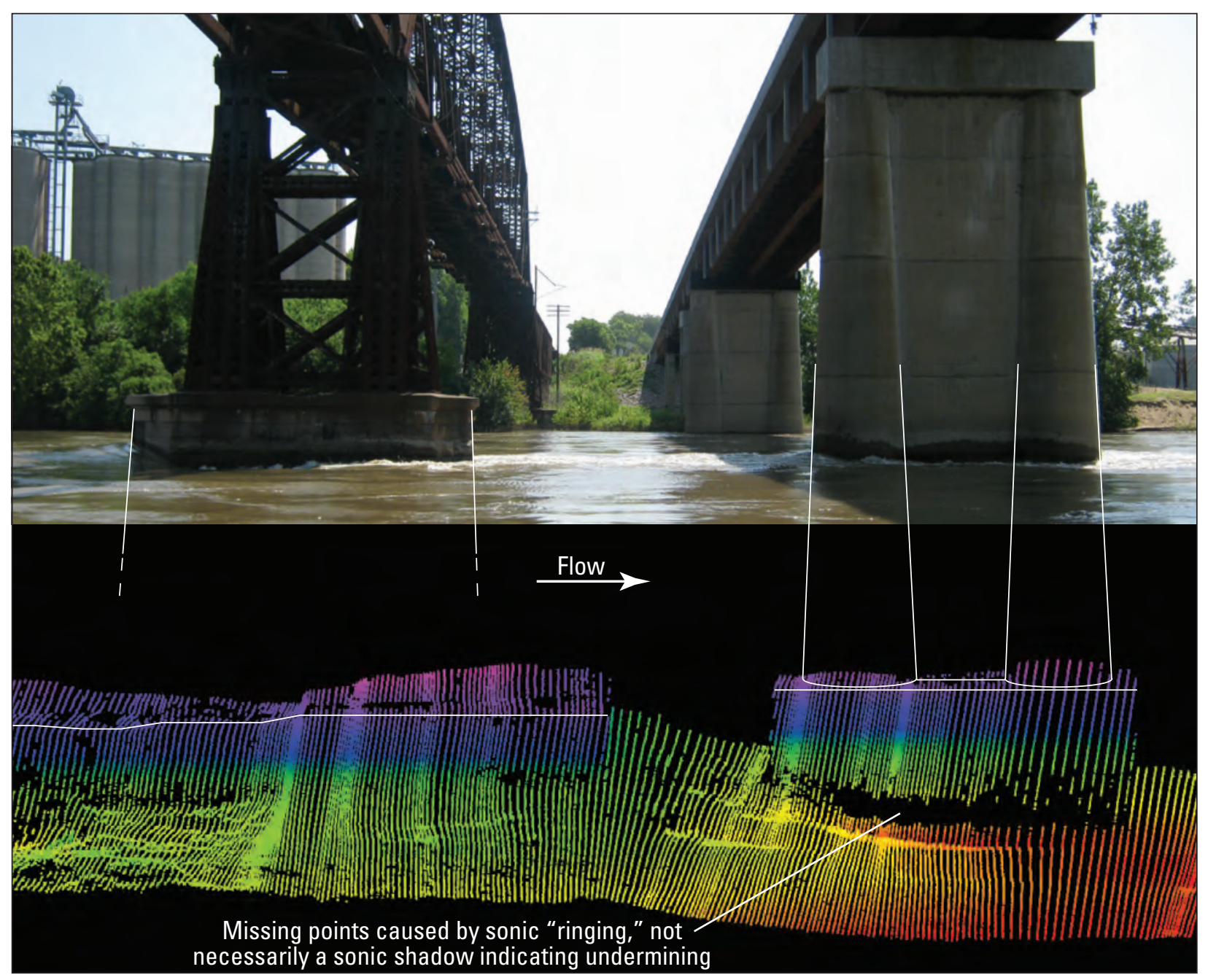

\section{EXPLANATION}

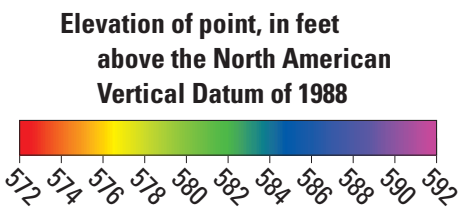

Figure 70. Point cloud visualization of the channel bed and right (west) side of main channel pier 2 of structure G0069 on State Highway 240 and the upstream railroad bridge pier over the Missouri River at Glasgow, Missouri. 


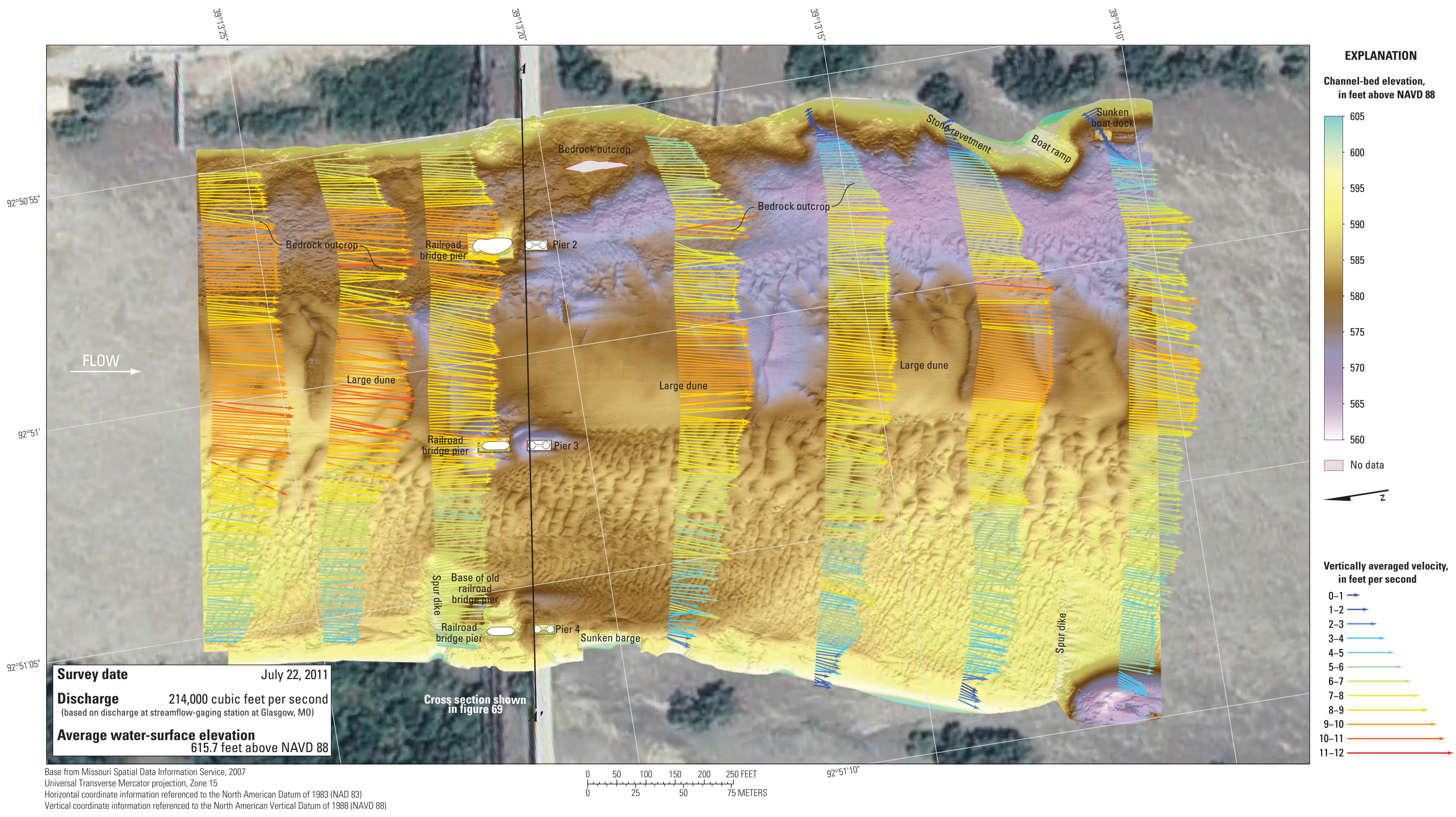

Figure 71. Bathymetry and vertically averaged velocities of the Missouri River channel in the vicinity of structure G0069 on State Highway 240 at Glasgow, Missouri. 


\section{Structure A4574 on State Highway 5 at Boonville, Missouri}

Structure A4574 (site 18) on State Highway 5 crosses the Missouri River at RM 196.6 at Boonville, Missouri, south of Glasgow and about halfway between Kansas City and St. Louis (fig. 1). The site was surveyed on July 25, 2011, and the average water-surface elevation of the river in the survey area, determined by the RTK GPS tide solution, was $590.9 \mathrm{ft}$ (table 5). Flow on the Missouri River was about 219,000 ft $\mathrm{ft}^{3} / \mathrm{s}$ during the survey, according to the streamgage at Boonville, Missouri (table 5).

The survey area was about 1,640 ft long and about $1,250 \mathrm{ft}$ wide, extending from bank to bank in the main channel (fig. 72). The upstream end of the survey area was about $620 \mathrm{ft}$ upstream from the centerline of structure A4574 (fig. 62), and piers 5 through 8 were in the water, although piers 5 and 8 were on the edges of the surveyed area. The channel-bed elevations ranged from about 554 to $569 \mathrm{ft}$ for most of the surveyed area ( 5 to 95 percentile range of the bathymetric data), except in the channel thalweg along the left (north) bank, where a series of large dunes and scour holes created local minimum channel-bed elevations ranging from 547 to $552 \mathrm{ft}$ (fig. 72). Numerous medium and small dunes and ripples were present throughout the channel (fig. 72). A longitudinal spur dike and stone revetment were present on the left (north) bank, and stone revetment appeared to be present near the bridge on the right (south) bank (fig. 72).

Minor scour holes were observed near the central main channel piers 6 and 7. In the vicinity of main channel pier 7 (fig. 72), the scour hole had a minimum channel-bed elevation of about $556 \mathrm{ft}$ (table 8), about $23 \mathrm{ft}$ above the elevation of the bottom of the pier seal course of $533.00 \mathrm{ft}$ (fig. 73; table 8). The minor scour hole near pier 6 had a minimum channel-bed elevation of about $559 \mathrm{ft}$ (table 8). Both scour holes were difficult to discern from nearby dunes and ripples (figs. 72, 73).
Information from bridge plans indicates that pier 7 is founded on shafts drilled $39 \mathrm{ft}$ into bedrock, with about $43 \mathrm{ft}$ of bed material between the bottom of the scour hole and bedrock (fig. 73; table 8). Pier 6 is founded on a footing on bedrock, with about $8 \mathrm{ft}$ of bed material between the bottom of the scour hole and bedrock (fig. 73; table 8). The surveyed bed generally was similar to the original ground line from bridge plans (1998), with localized areas of scour and deposition across the section (fig. 73).

Main channel piers 5 and 8 were along the edges of the surveyed area. Pier 8 is immediately downstream from a longitudinal spur dike, and its proximity to the left (north) bank made it impossible to survey on the left (north) side of the pier. A scour hole near the downstream toe of the spur dike reached a minimum channel-bed elevation of about $548 \mathrm{ft}$ (table 8), about $21 \mathrm{ft}$ above the elevation of the bottom of the pier seal course of $527.00 \mathrm{ft}$ (fig. 73; table 8). Pier 5 is situated on a protruding point of the right (south) bank, and no scour hole was observed near this pier (figs. 72, 73), which is founded on a footing on bedrock according to bridge plans (fig. 73; table 8). At the toe of the right bank near pier 5, the channel-bed elevation was about $564 \mathrm{ft}$, which was about $4 \mathrm{ft}$ above the bedrock near the pier (fig. 73; table 8). In modern construction, bridge substructural elements usually are pinned or socketed to bedrock (American Association of State Highway Transportation Officials, 2012; Brown and others, 2010), but full exposure of usually buried substructural elements warrants special consideration and observation.

The vertically averaged velocity vectors indicate mostly uniform flow throughout most of the channel, ranging from about 4 to $9 \mathrm{ft} / \mathrm{s}$ (fig. 74), except along the banks. Moderate turbulence was observed in the channel thalweg at and downstream from the bridge (fig. 74), and local flow reversal and turbulence was observed along the right (south) bank (fig. 74). The bridge piers were aligned with flow, causing little to no evident turbulence downstream (fig. 74).

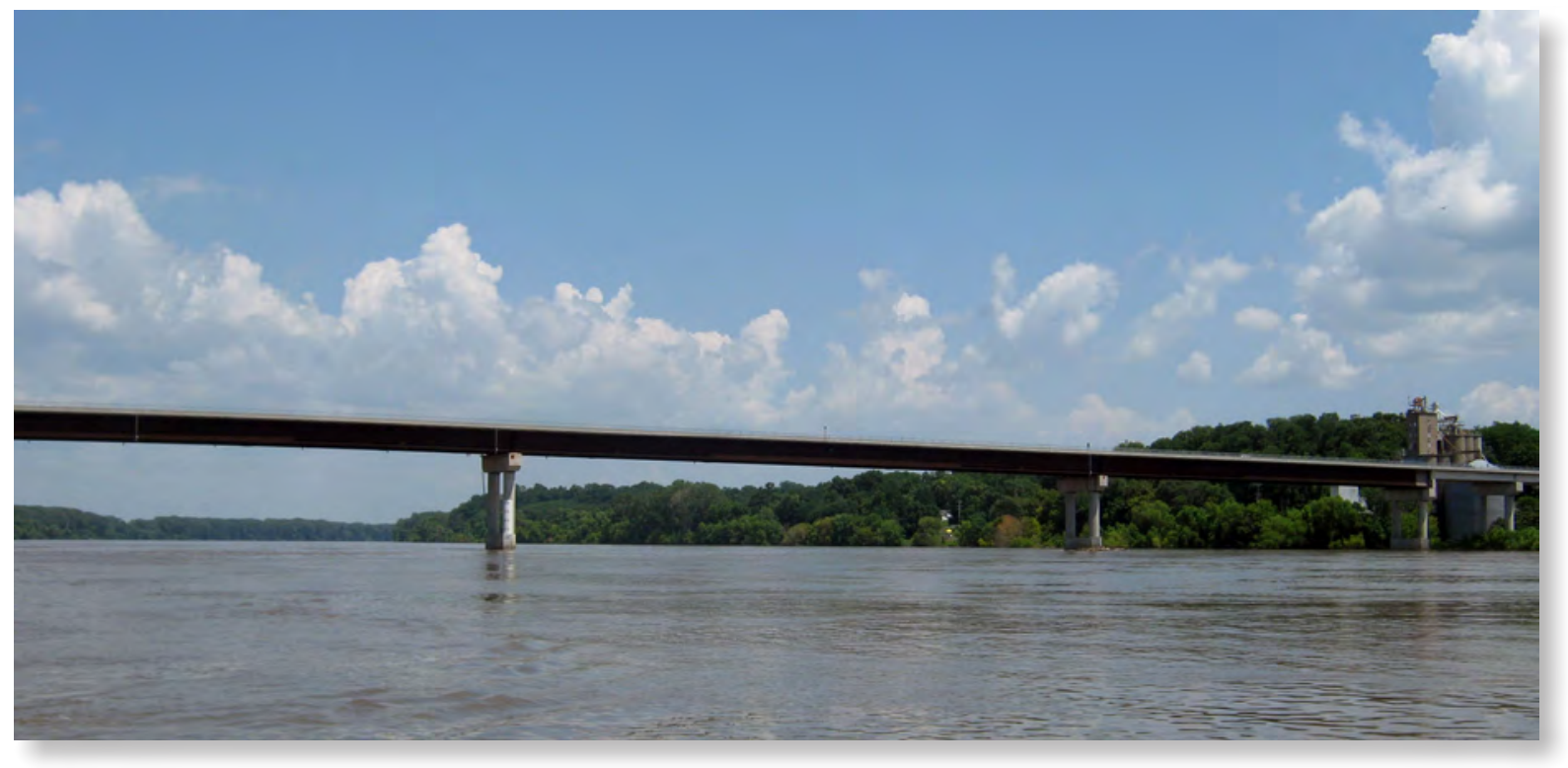

Structure A4574 on State Highway 5 at Boonville, Missouri. Photograph by Joseph Richards, USGS. 


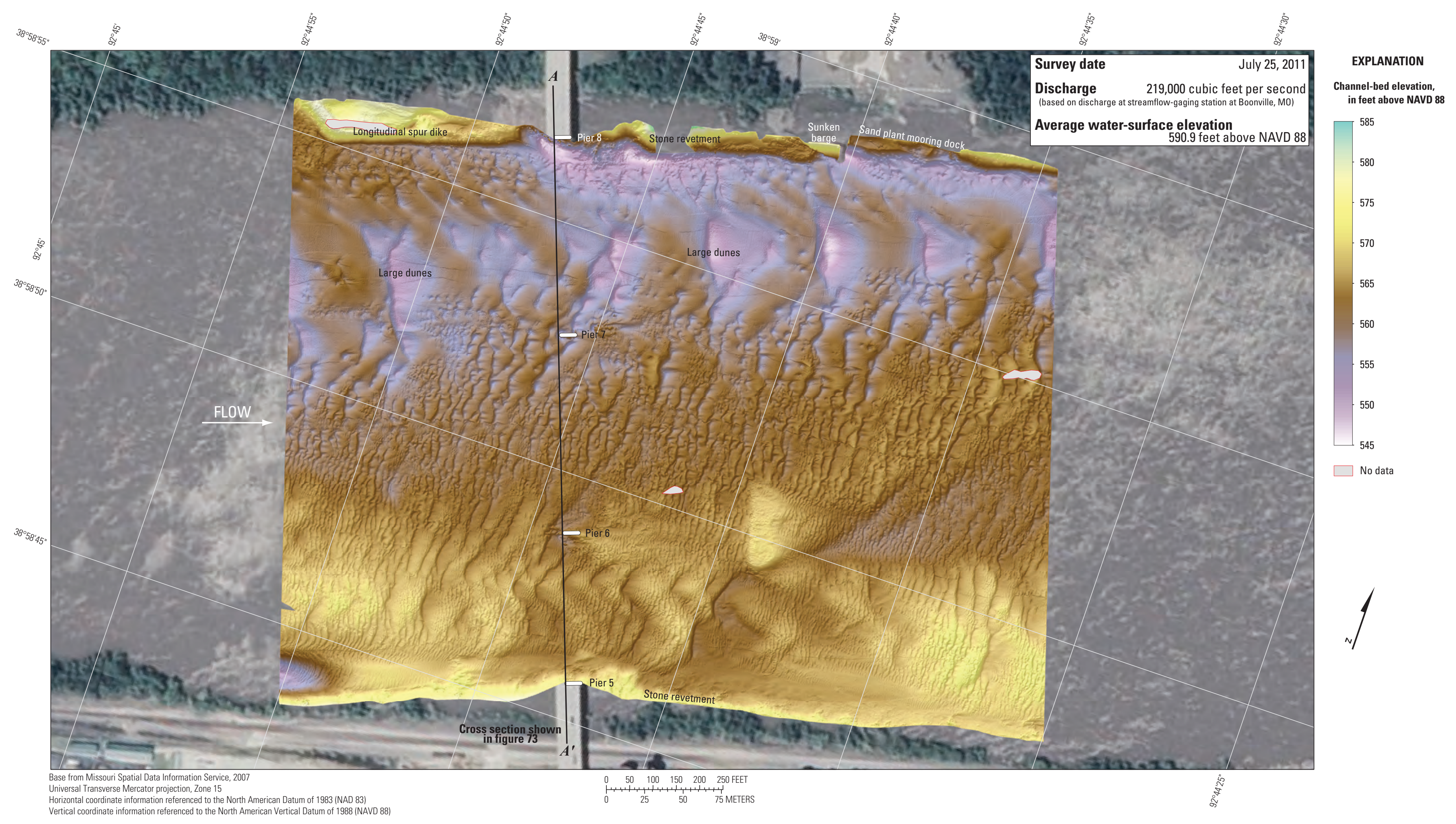

Figure 72. Bathymetric survey of the Missouri River channel in the vicinity of structure A4574 on State Highway 5 at Boonville, Missouri. 


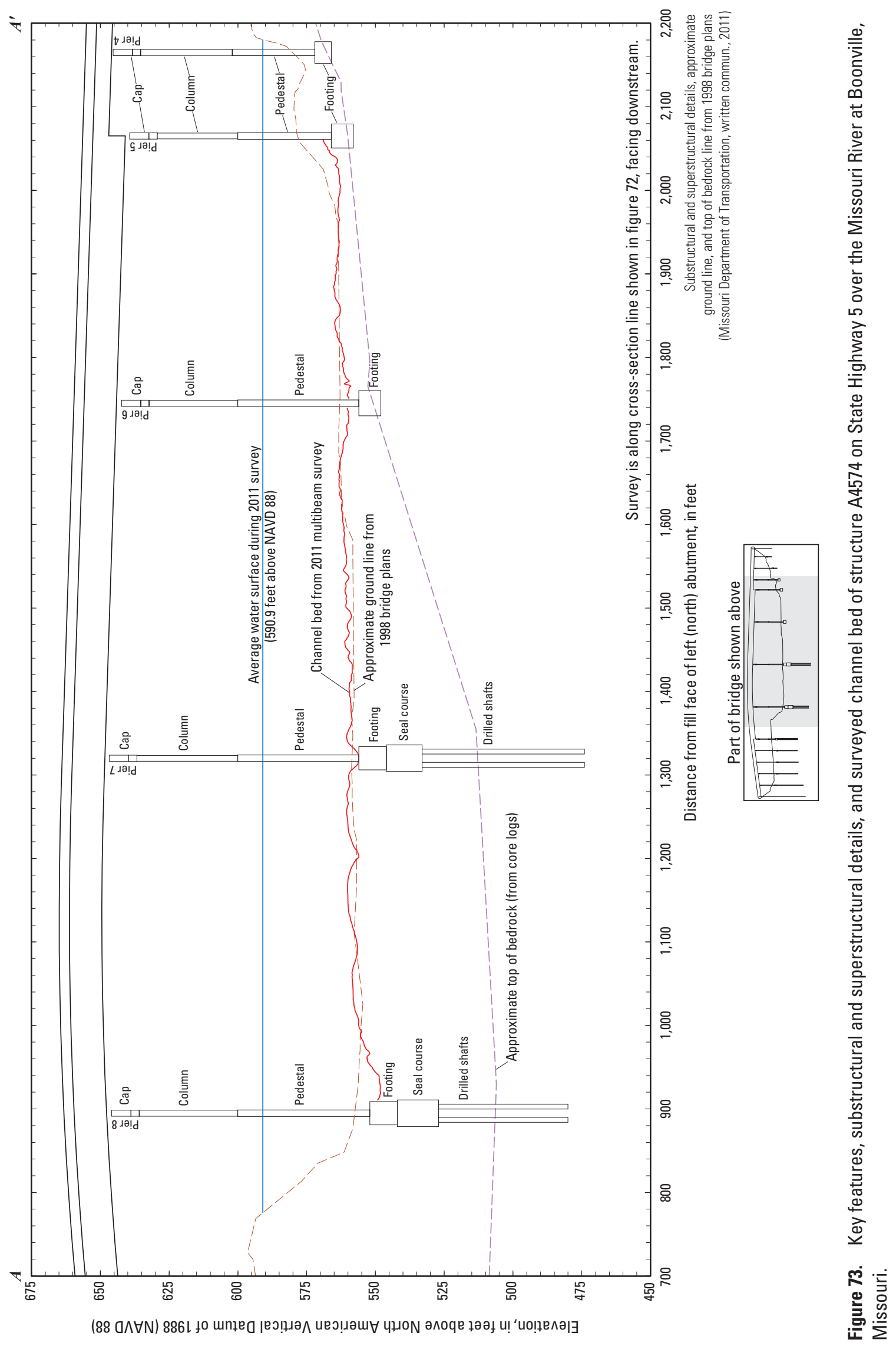




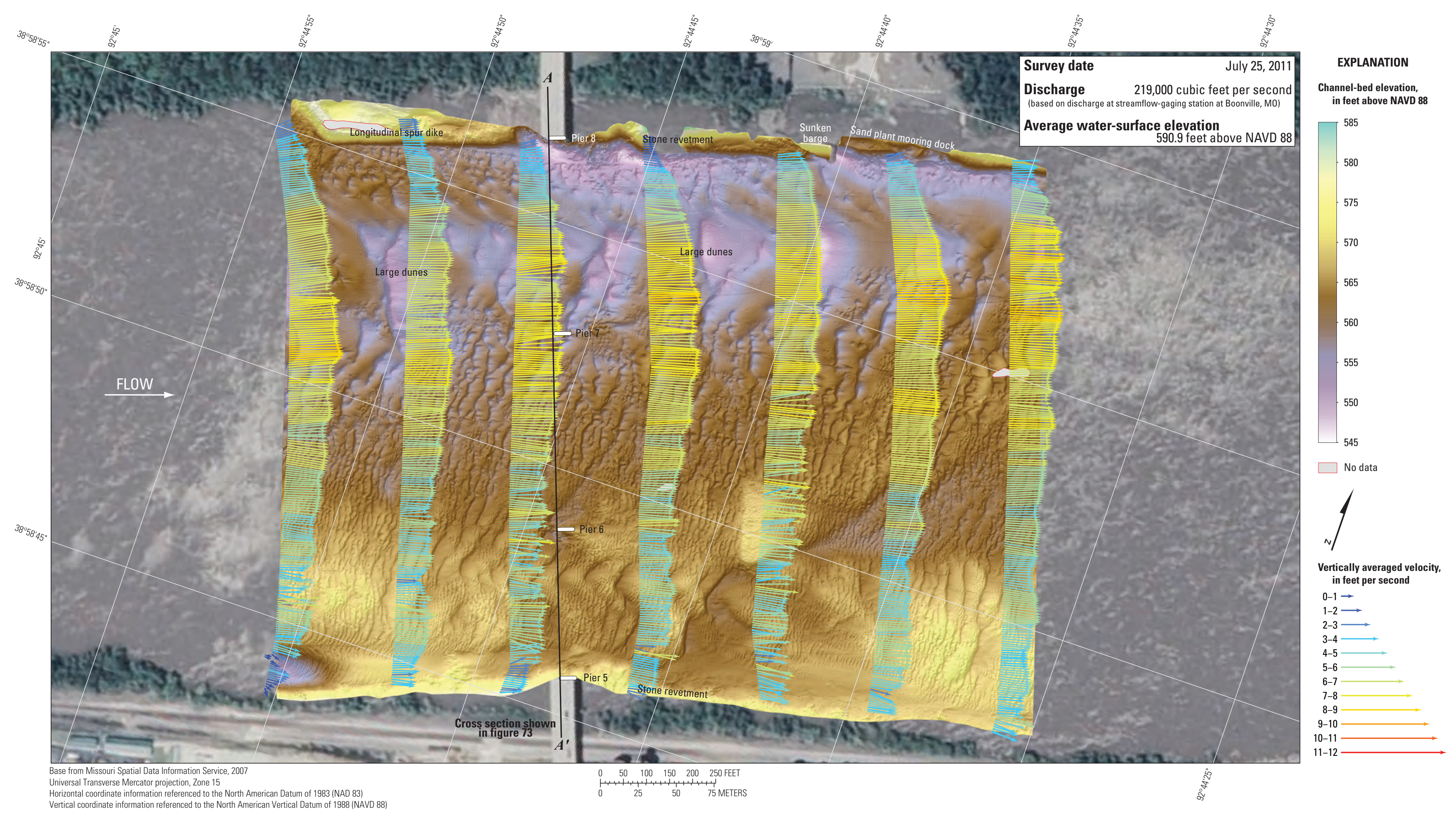

Figure 74. Bathymetry and vertically averaged velocities of the Missouri River channel in the vicinity of structure A4574 on State Highway 5 at Boonville, Missouri. 


\section{Structure L0962 on Interstate 70 near Rocheport, Missouri}

Structure L0962 (site 19) on Interstate 70 crosses the Missouri River at RM 185.1 near Rocheport, Missouri, east of Boonville and west of St. Louis (fig. 1). The site was surveyed on July 26, 2011, and the average water-surface elevation of the river in the survey area, determined by the RTK GPS tide solution, was $580.9 \mathrm{ft}$ (table 5). Flow on the Missouri River was about $219,000 \mathrm{ft}^{3} / \mathrm{s}$ during the survey, according to the streamgage at Boonville, Missouri (table 5).

The survey area was about 1,640 ft long and about $1,180 \mathrm{ft}$ wide, extending from bank to bank in the main channel (fig 75). The upstream end of the survey area was about $580 \mathrm{ft}$ upstream from the centerline of structure L0962 (fig. 62), and piers 14 and 15 and bent 16 were in the water. The channel-bed elevations ranged from about 534 to $560 \mathrm{ft}$ for most of the surveyed area ( 5 to 95 percentile range of the bathymetric data), except near pier 14, in the channel thalweg along the left (north) bank and downstream from the various spur dikes (fig. 75). A series of very large dunes was present in the middle of the channel, and numerous medium and small dunes and ripples were present throughout the rest of the channel (fig. 75). Several longitudinal spur dikes were present on the left (north) bank, and a spur dike was present on the downstream right (south) bank (fig. 75). A substantial debris raft was present on the left bank between pier 15 and bent 16 , which created a shallow area that extended from the upstream end of the longitudinal dike to a point about $125 \mathrm{ft}$ downstream from structure L0962 for which no bathymetric data could be collected (fig. 75). A single survey swath was obtained between the left bank and the left side of the debris pile (fig. 75)

In the vicinity of main channel pier 14 (fig. 75), a substantial scour hole had a minimum channel-bed elevation of about $525 \mathrm{ft}$ (table 8), about $19 \mathrm{ft}$ below the average channel elevation upstream from the bridge (fig. 76; table 8). Information from bridge plans indicates that pier 14 is founded on a caisson on bedrock, with about $27 \mathrm{ft}$ of bed material between the bottom of the scour hole and bedrock (fig. 76; table 8). Pier 15 is embedded in the longitudinal spur dike, and the minimum channel elevation at the toe of the dike was about $530 \mathrm{ft}$ (figs. 75, 76; table 8). Pier 15 also is founded on a caisson on bedrock, with about $11 \mathrm{ft}$ of material between the minimum channel elevation and bedrock (fig. 76; table 8); however, the rock of the spur dike will limit or prevent a local scour hole near pier 15 . Bent 16 is founded on a footing on bedrock, likely with $20 \mathrm{ft}$ or more of bed material between the channel bed and bedrock based on the minimum elevation of the single survey swath obtained near bent 16 (fig. 76). The surveyed bed was substantially different from the ground line from the Level II bridge scour assessment in 2002, with as much as $20 \mathrm{ft}$ of scour in the channel thalweg and as much as $10 \mathrm{ft}$ of scour between pier 14 and the right bank (fig. 76).

The vertically averaged velocity vectors indicate areas of uniform flow with areas of substantial turbulence (fig. 77). Velocities ranged from about 4 to $11 \mathrm{ft} / \mathrm{s}$ for most of the channel (fig. 77), except in the vicinity of the spur dikes. Substantial turbulence was observed in the transect upstream from the bridge (fig. 77), and local flow reversal and turbulence were observed along the left (north) bank (fig. 77). Pier 14 was aligned with flow, causing no evident turbulence downstream (fig. 77).

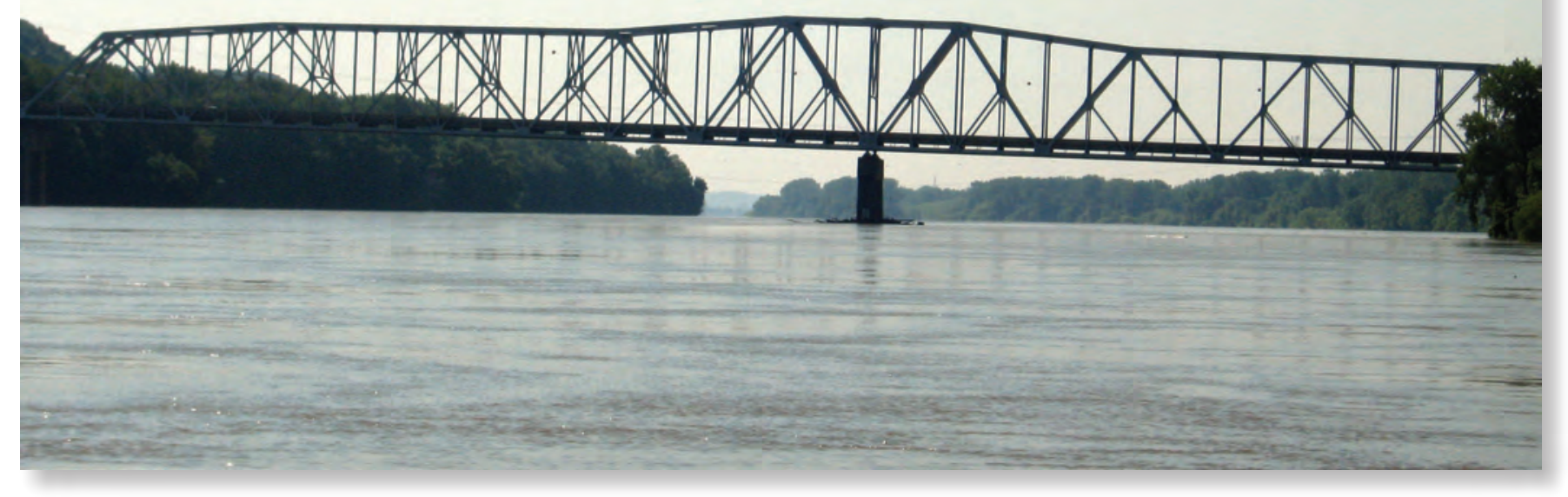

Structure L0962 on Interstate 70 near Rocheport, Missouri. Photograph by Joseph Richards, USGS 


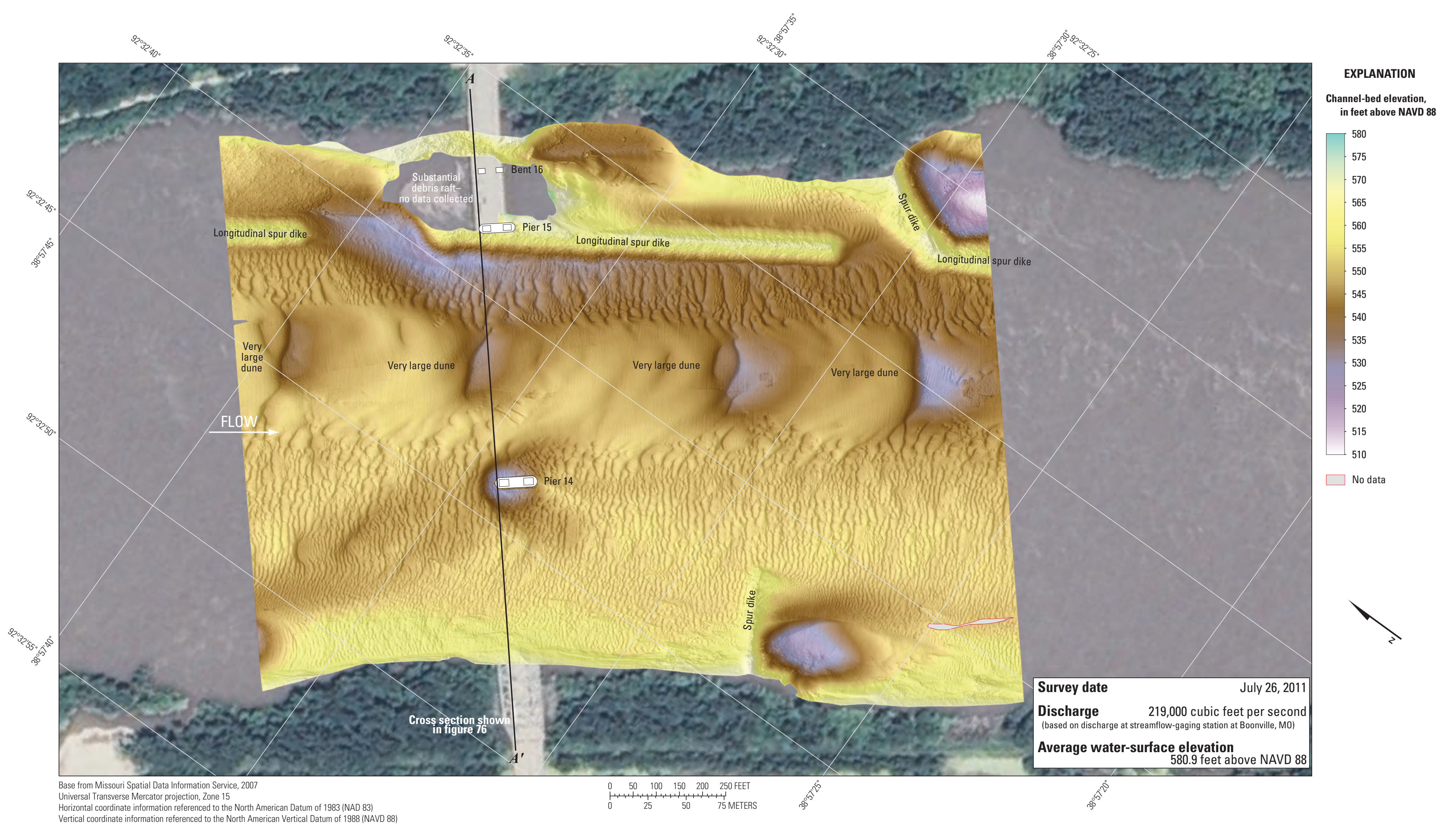

Figure 75. Bathymetric survey of the Missouri River channel in the vicinity of structure L0962 on Interstate 70 near Rocheport, Missouri. 


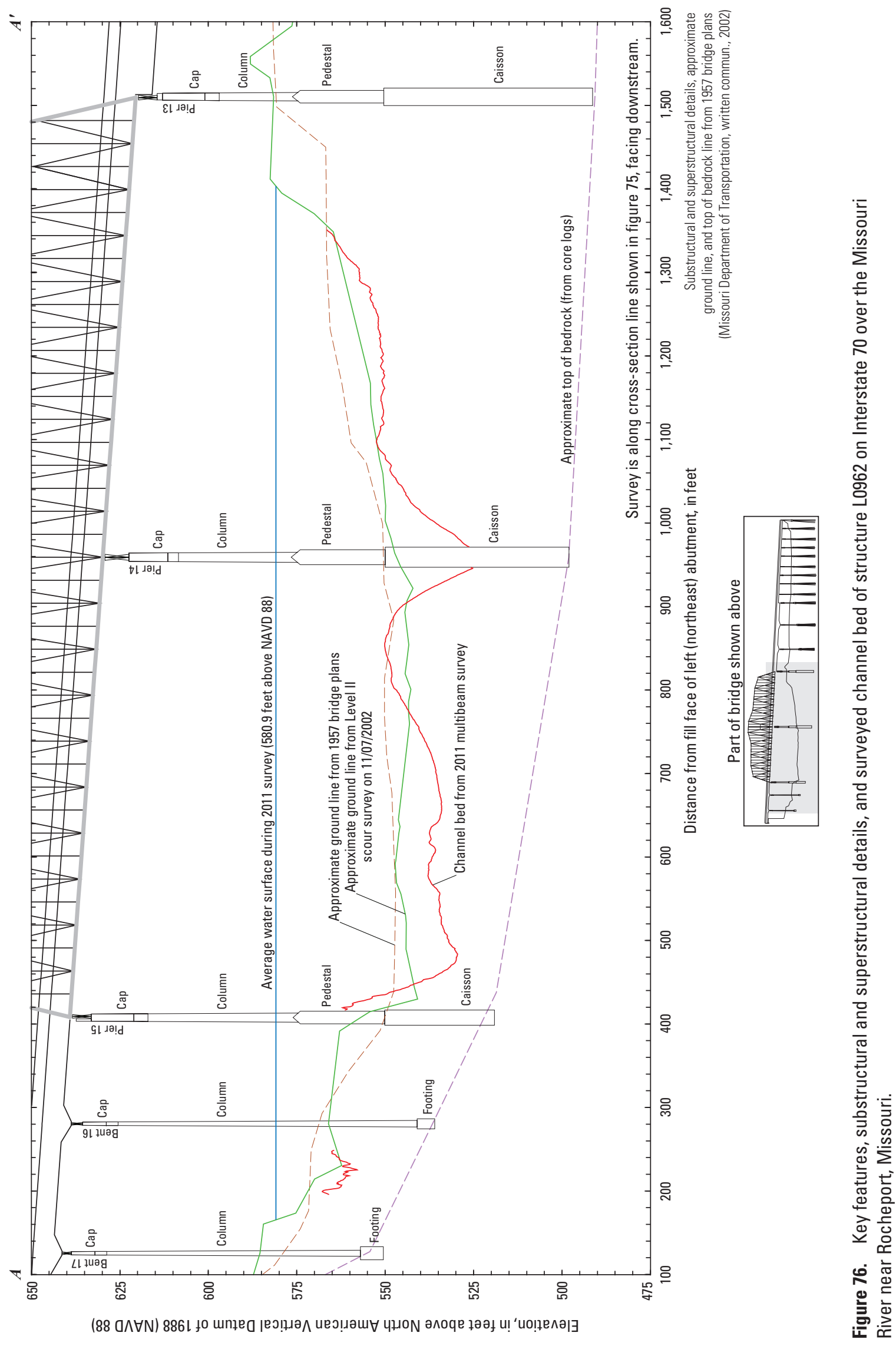




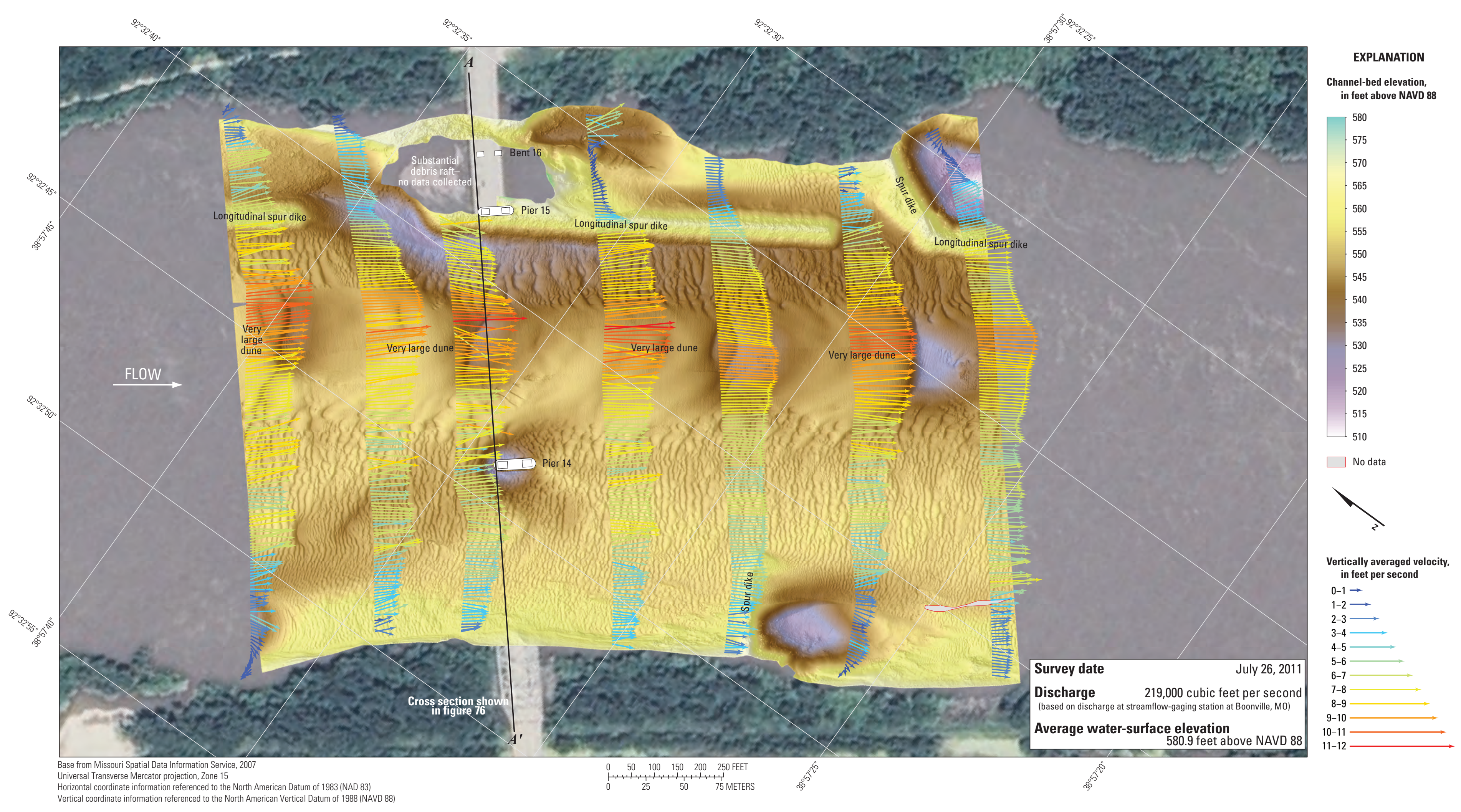

Figure 77. Bathymetry and vertically averaged velocities of the Missouri River channel in the vicinity of structure L0962 on Interstate 70 near Rocheport, Missouri. 


\section{Structures L0550 and A4497 on U.S. Highway 54 at Jefferson City, Missouri}

Structures L0550 and A4497 (site 20) are dual bridges on U.S. Highway 54 crossing the Missouri River at RM 143.9 at Jefferson City, Missouri, southeast of Rocheport and west of St. Louis (fig. 1). The site was surveyed on July 27, 2011, and the average water-surface elevation of the river in the survey area, determined by the RTK GPS tide solution, was $544.7 \mathrm{ft}$ (table 5). Flow on the Missouri River was about 219,000 $\mathrm{ft}^{3} / \mathrm{s}$ during the survey, according to the streamgage at Boonville, Missouri (table 5).

The survey area was about 1,640 ft long and about $1,010 \mathrm{ft}$ wide, extending from bank to bank in the main channel (fig 78). The upstream end of the survey area was about $630 \mathrm{ft}$ upstream from the centerline between structures L0550 and A4497 (fig. 78), and only pier 4 of each structure was in the water and away from the banks. The channel-bed elevations ranged from about 495 to $525 \mathrm{ft}$ for most of the surveyed area (5 to 95 percentile range of the bathymetric data), except near the piers (fig. 78). A series of large dunes was present in the middle of the upstream channel, and numerous medium and small dunes and ripples were present throughout the rest of the channel (fig. 78). A spur dike was present on the upstream left (north) bank, and stone revetment was present on the right (south) bank throughout the reach (fig. 78).

A substantial scour hole was observed near the main channel piers. In the vicinity of pier 4 of upstream structure L0550 (fig. 78), the scour hole had a minimum channel-bed elevation of about $463 \mathrm{ft}$ (table 8), about $35 \mathrm{ft}$ below the average channel elevation upstream from the bridge (fig. 79; table 8). Information from bridge plans indicates that pier 4 of structure L0550 is founded on a caisson on bedrock, with only about $4 \mathrm{ft}$ of bed material between the bottom of the scour hole and bedrock (fig. 79; table 8). The scour hole near pier 4 of downstream structure A4497 was substantially affected by the upstream pier, with a minimum channel-bed elevation of about $481 \mathrm{ft}$ (table 8), about $12 \mathrm{ft}$ below the elevation of the bottom of the pier seal course of $493.50 \mathrm{ft}$ (fig. 80; table 8). Pier 4 of structure A4497 is founded on shafts drilled $11 \mathrm{ft}$ into bedrock, with about $22 \mathrm{ft}$ of bed material between the bottom of the surveyed scour hole and bedrock (fig. 80; table 8). The surveyed bed was similar to the ground line from the Level II bridge scour assessment in 2002 in the channel to the left of pier 4 at both bridges, except for as much as $25 \mathrm{ft}$ of scour along the toe of the right (west) bank compared to the Level II ground line (figs. 79, 80). In modern construction, bridge substructural elements usually are pinned or socketed to bedrock (American Association of State Highway Transportation Officials, 2012; Brown and others, 2010), but full exposure of usually buried substructural elements warrants special consideration and observation.

Structures L0550 and A4497 were the subject of a realtime scour monitoring project during 2011 using fixed, singlebeam acoustic transducers attached to the upstream nose of pier 4 at each bridge (see Rydlund, 2009, for a similar study).
Bathymetric surveys of the area were performed for reconnaissance in January 2010, and again during spring flooding in March 2011, in an attempt to identify problems with the upstream monitor. These surveys provide additional bathymetric surfaces (fig. 81) that can be compared to the survey from July 27,2011 . The bathymetric surface from the survey on January 26, 2010 (fig. 81A), had substantially fewer dune features in the channel, whereas the surface from the survey on March 1, 2011 (fig. 81B), had more dunes than in January 2010 , but fewer than in July 2011. These differences in bedforms may be the result of different water temperatures during the surveys, which affects the water viscosity and has been shown to affect the formation of bedforms in alluvial channels (Simon, Li and Associates, 1985); however, water temperature differences do not explain the same kind of bedform differences observed at two of the bridge sites examined during this study [structure A1800 (site 6) and structures K0456 and A0450 (site 7)]. The scour hole near the piers appears more square in the January 2010 survey than in the other surveys, but otherwise the holes are similar in appearance and depth (figs. 78, 81). The scour hole at downstream structure A4497 appeared to be consistent in size and depth between the various surveys (fig. 80); however, the scour hole at upstream structure L0550 was substantially deeper in the July 2011 survey than the other surveys by more than $10 \mathrm{ft}$ (fig. 79).

The real-time scour monitors were collecting data during the March 2011 and July 2011 surveys. The monitor attached to pier 4 of upstream structure L0550 was struck and bent on February 26, 2010, such that it was returning a signal from the top of the caisson (elevation $513 \mathrm{ft}$ ) rather than the channel bed; however, the monitor on pier 4 of downstream structure A4497 functioned flawlessly through both events. During the March 2011 survey, the monitor sensed an average bed elevation of $485.9 \mathrm{ft}$ during the survey. The bed elevation near the center of the nose of the downstream pier during the survey was about $483.0 \mathrm{ft}$, about $3 \mathrm{ft}$ lower than the monitor. During the July 2011 survey, the monitor sensed an average bed reading of $485.4 \mathrm{ft}$ during the survey. The bed elevation near the center of the nose of the pier during that survey was about $482.2 \mathrm{ft}$, again about $3 \mathrm{ft}$ lower than the monitor.

There are several sources of error that might contribute to the difference between the elevations from the MBES and the channel-bed monitor. First, it was necessary to program the approximate elevation of the monitor when the monitor was installed in November 2010, and it is possible that the monitor elevation was set incorrectly because of potential inaccuracies of measurement. Second, and more significantly, the monitor transducer was tilted forward from vertical to allow the beam to clear the top of the footing and seal course (fig. 82), resulting in uncertainty about the exact location of the transducer beam in the scour hole. It is known that the transducer is obtaining its return signal from someplace on the front of the hole, and it was assumed that the distance from the monitor to the channel bed at the front of the hole is approximately the same as the depth directly below the monitor (fig. 82), but this may not be a totally accurate assumption in all cases. 
Furthermore, the front of the scour hole can be dynamic - for example, a sand dune may wash into the hole and subsequently erode away because of the horseshoe vortex at the pier nose - and this will affect the distance measurement from the transducer, and thereby the recorded "depth" of the hole. Ultimately, the differences between the MBES and monitor elevations are deemed to be reasonable, and the downstream monitor has functioned as designed with a tolerance of plus or minus $3 \mathrm{ft}$. The upstream monitor was repaired on January 11, 2012. Both monitors have documented scour holes forming during flood events and filling during flood recessions and low-flow periods (Paul Rydlund, U.S. Geological Survey, unpub. data, 2012).

The difference between the surveys on July 27,2011 , and January 26, 2010 (fig. 83), indicates substantial scour of as much as $20 \mathrm{ft}$ has occurred throughout the channel, with small areas of deposition of as much as $10 \mathrm{ft}$ downstream from the spur dike and the boat ramp on the left (north) bank and around the submerged object near the piers. The average difference between the January 2010 and July 2011 bathymetric surfaces is $-4.92 \mathrm{ft}$ (table 7), indicating moderate to substantial scour overall. The difference between the surveys on July 27, 2011, and during the spring flooding on March 1, 2011 (fig. 84), indicates slightly more widespread scour of as much as $20 \mathrm{ft}$ throughout the channel, with smaller areas of deposition as much as $7 \mathrm{ft}$ near the spur dike and boat ramp on the left (north) bank and around the submerged object near the piers. The average difference between the March 2011 and July 2011 bathymetric surfaces is $-5.40 \mathrm{ft}$ (table 7), again indicating moderate to substantial scour overall. In both of the difference maps (figs. 83, 84), the appearance of substantial deposition or scour near the piers results from minor horizontal positional variances between the surveys; however, there was as much as $15 \mathrm{ft}$ of additional scour near the upstream left side of pier 4 of upstream structure L0550 between the January 2010 and July 2011 scans (figs. 79, 83), and as much as $10 \mathrm{ft}$ of additional scour between the March 2011 and July 2011 scans (figs. 79, 84). Although the January 2010 and March 2011 scans had similar water-surface elevations near the bridges, the flow rates were moderately different from each other $\left(10,000 \mathrm{ft}^{3} / \mathrm{s}\right.$ difference; table 7), and substantially different from the July 2011 flood (more than 64,000 $\mathrm{ft}^{3} / \mathrm{s}$ difference; table 7).

The vertically averaged velocity vectors indicate uniform flow in the downstream reach, and areas of substantial turbulence in the upstream reach, particularly near the spur dike on the upstream left (north) bank (fig. 85). Velocities ranged from about 3 to $10 \mathrm{ft} / \mathrm{s}$ for most of the channel (fig. 85), except in the vicinity of the spur dike, where low velocities and flow reversals were observed. Moderate to substantial turbulence also was observed in the transects upstream from the bridge (fig. 85). The piers of both bridges generally were aligned with flow, causing no evident turbulence downstream (fig. 85).

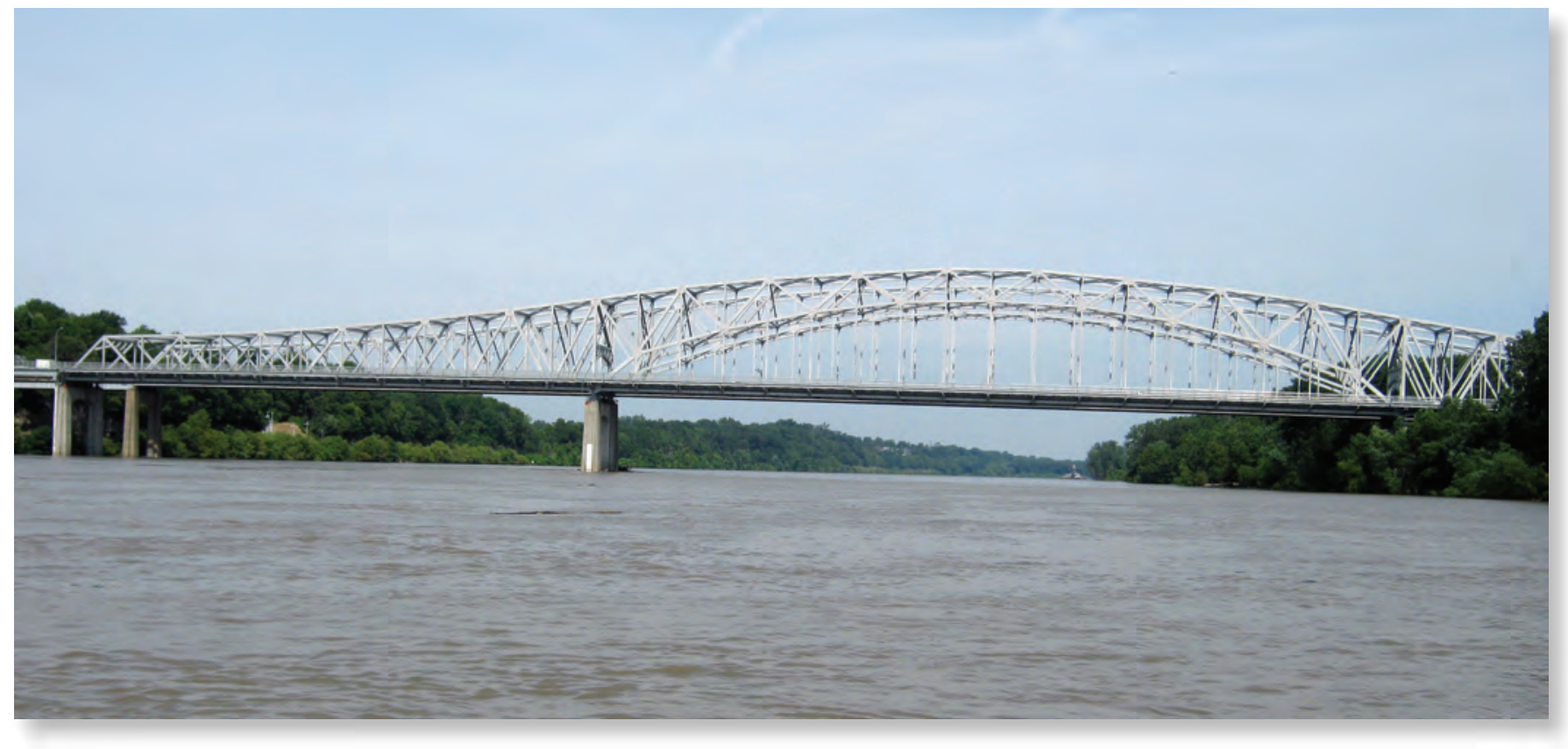

Structures L0550 and A4497 on U.S. Highway 54 at Jefferson City, Missouri. Structure A4497 is in the foreground, and L0550 is in the background. Photograph by Joseph Richards, USGS. 


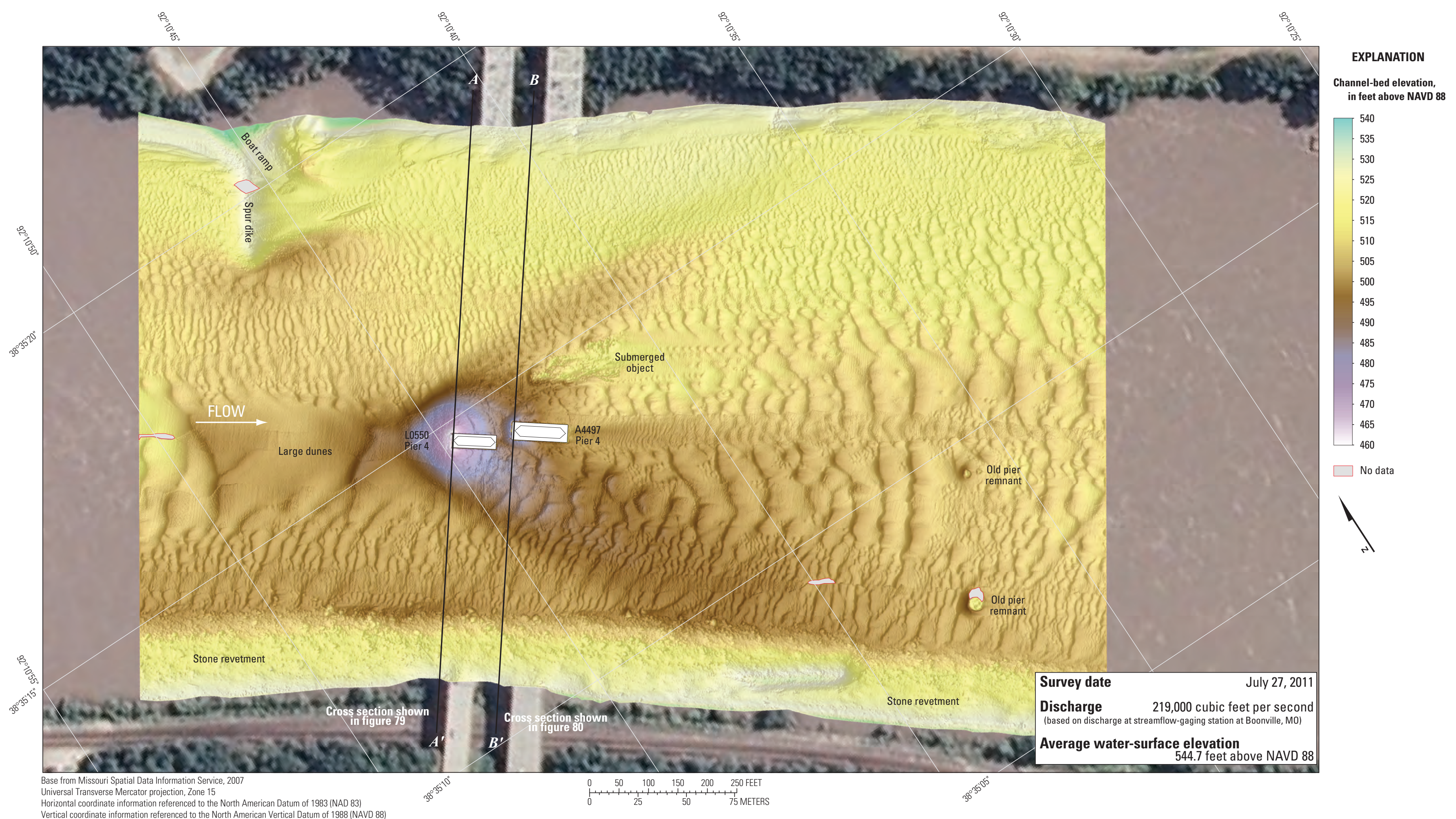

Figure 78. Bathymetric survey of the Missouri River channel in the vicinity of structures L0550 and A4497 on U.S. Highway 54 at Jefferson City, Missouri. 


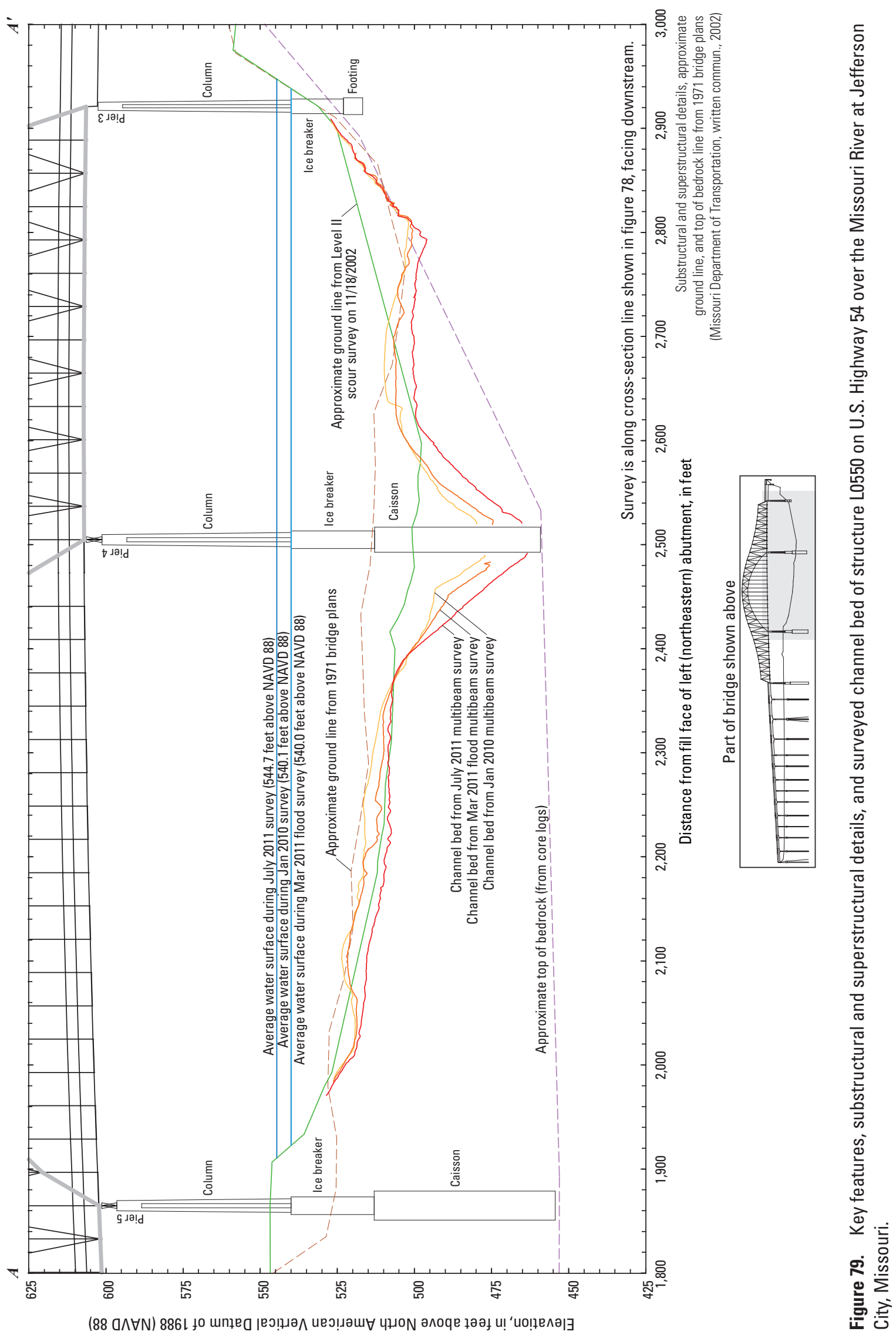




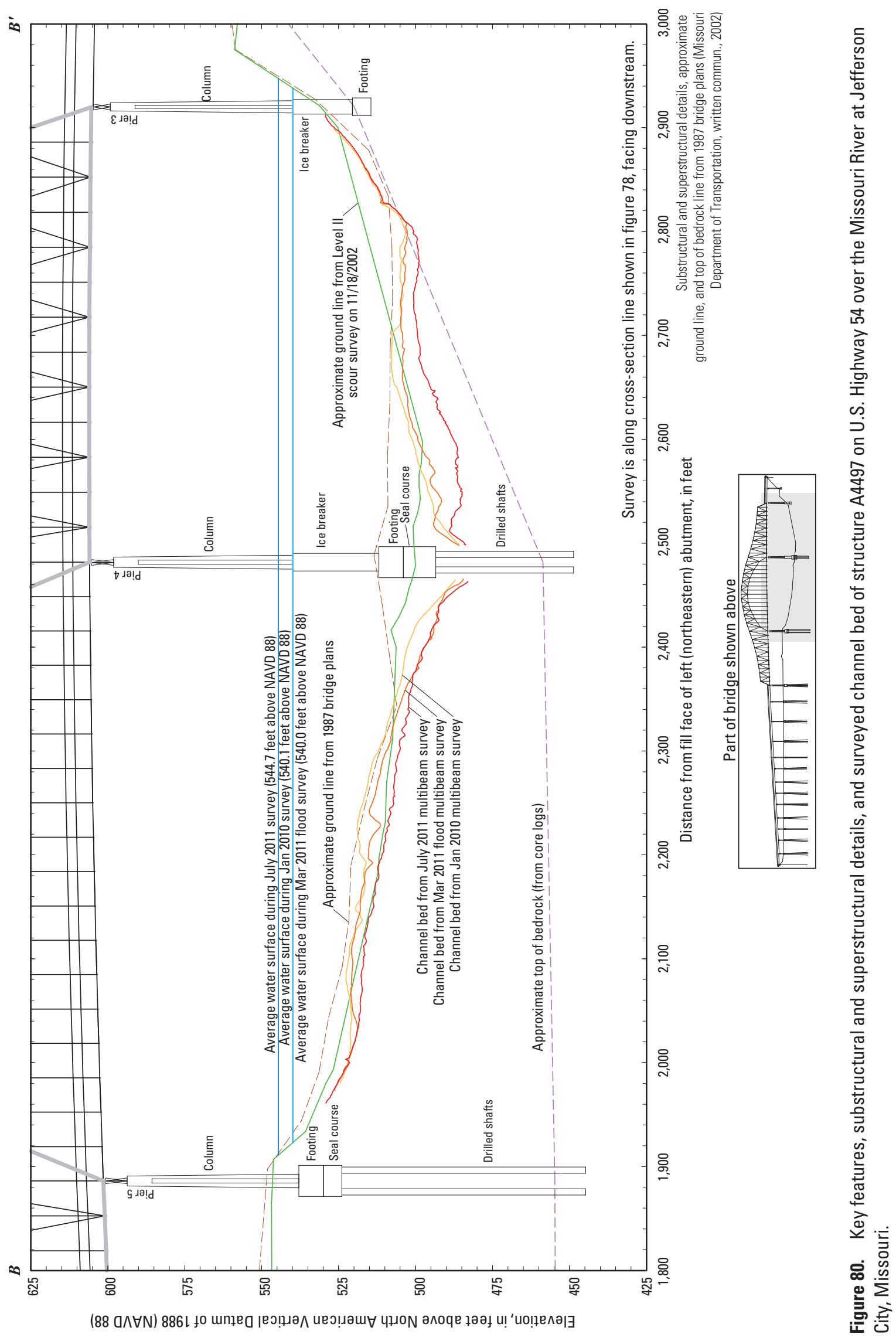




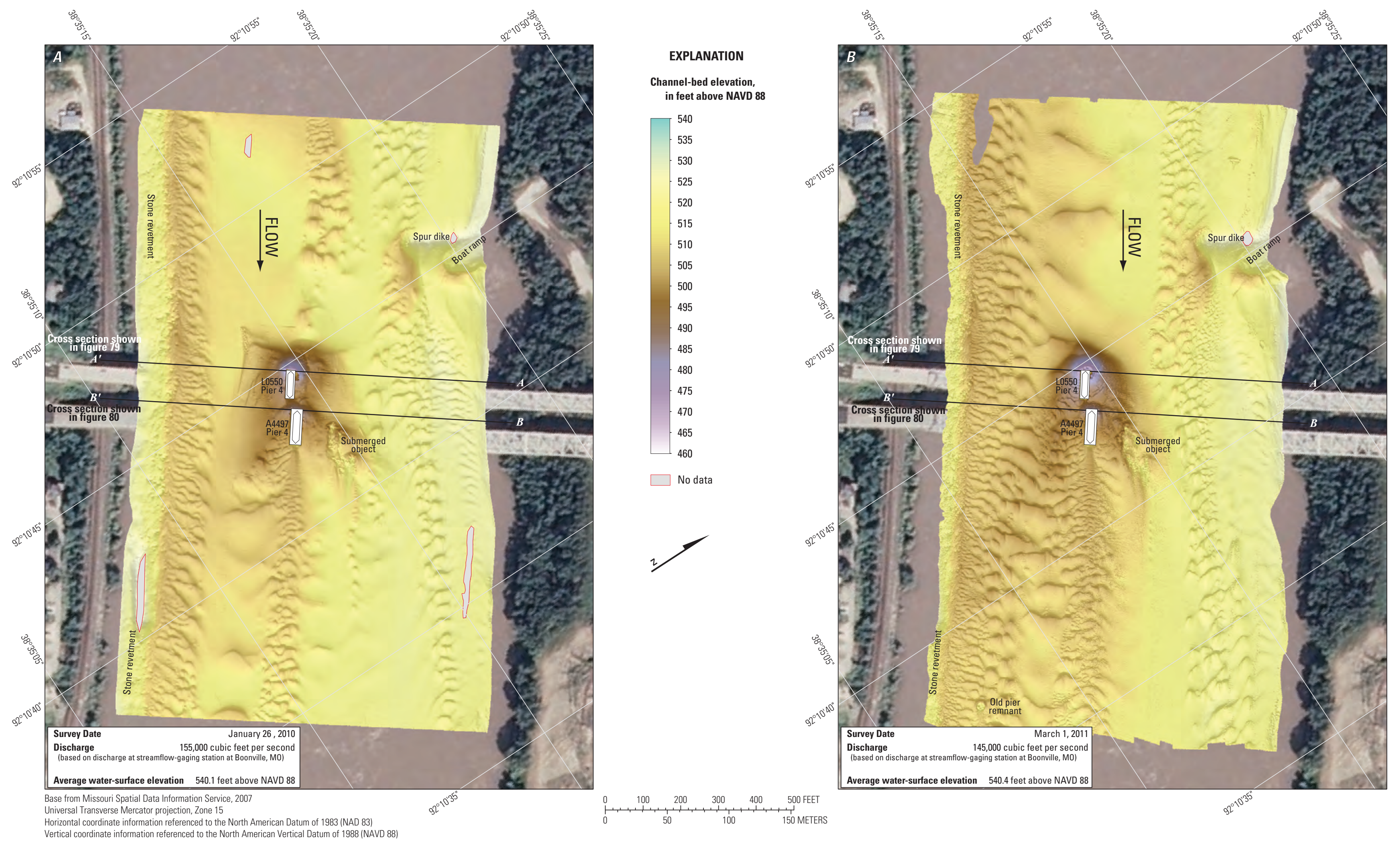

Figure 81. Bathymetric surveys of the Missouri River channel in the vicinity of structures L0550 and A4497 on U.S. Highway 54 at Jefferson City, Missouri, on A, January 26, 2010, and B, March 1, 2011. 


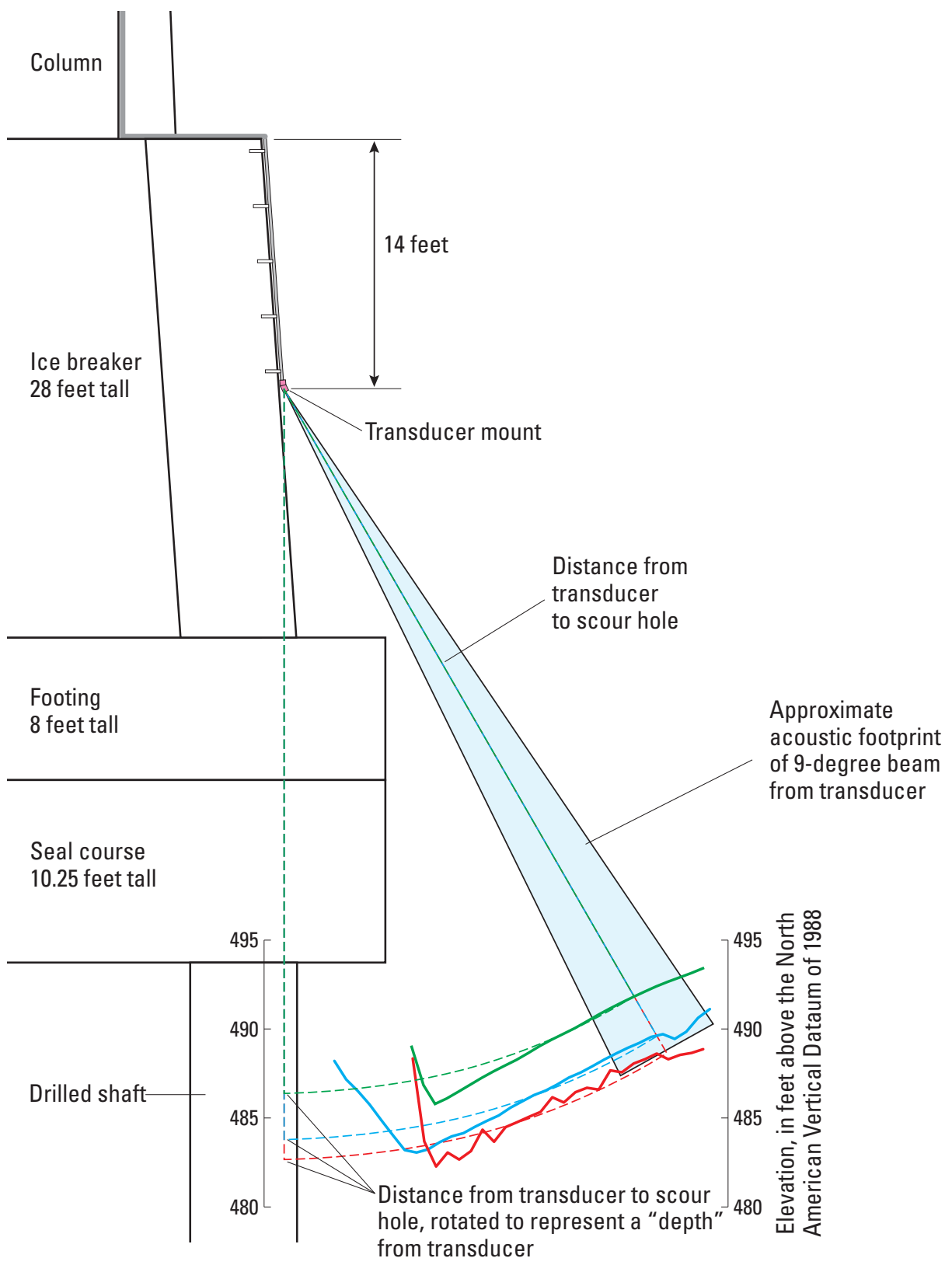

EXPLANATION

Approximate longitudinal section of scour hole along centerline of pier, from bathymetric survey on

- January 26, 2010

March 1, 2011

July 27, 2011

Figure 82. Design and approximate function of the channel-bed monitor at pier 4 of structure A4497 on U.S. Highway 54 over the Missouri River at Jefferson City, Missouri. 


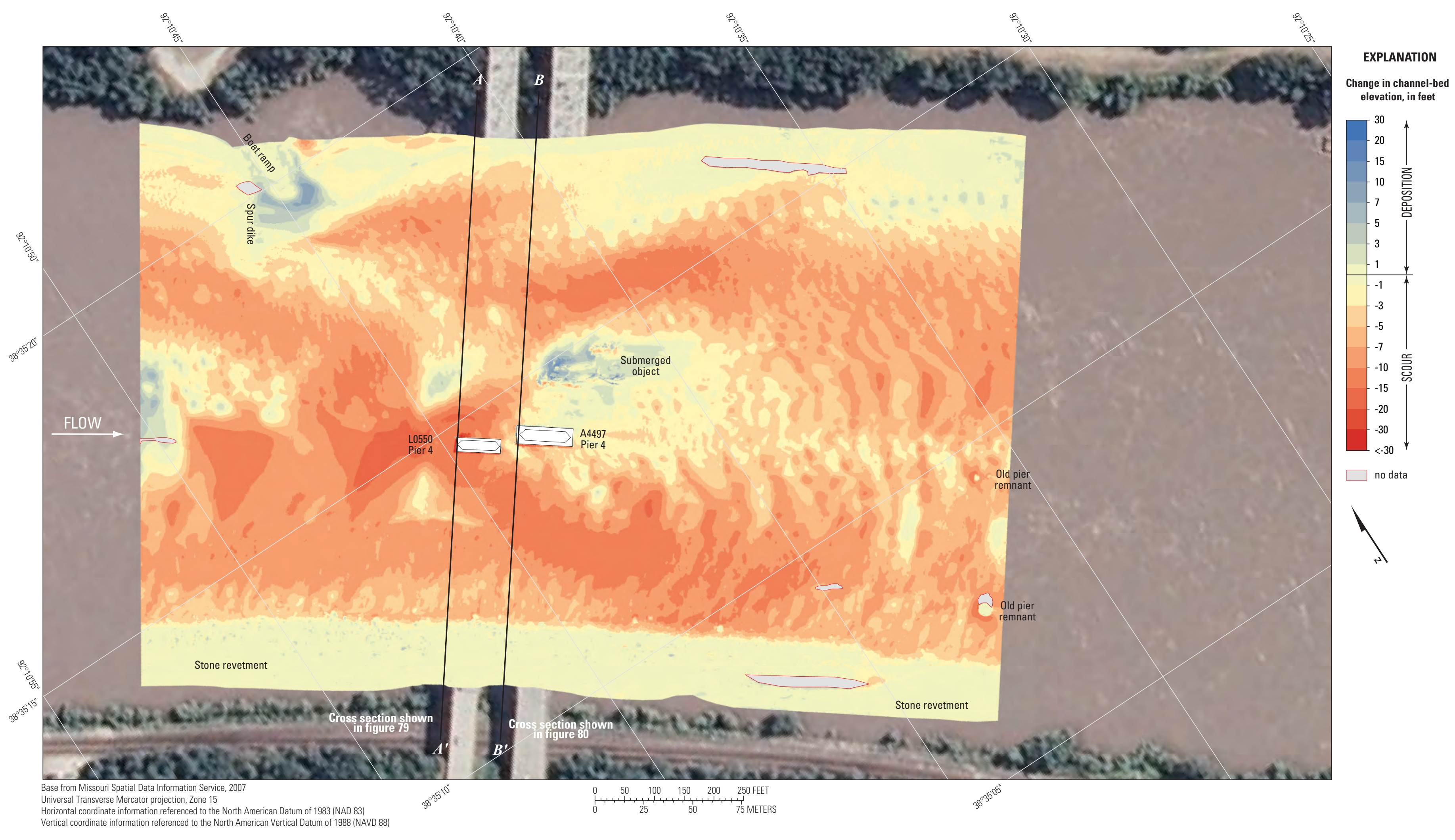

Figure 83. Difference between surfaces created from bathymetric surveys of the Missouri River channel in the vicinity of structures L0550 and A4497 on U.S. Highway 54 at Jefferson City, Missouri, on January 26, 2010 , and July 27, 2011. 


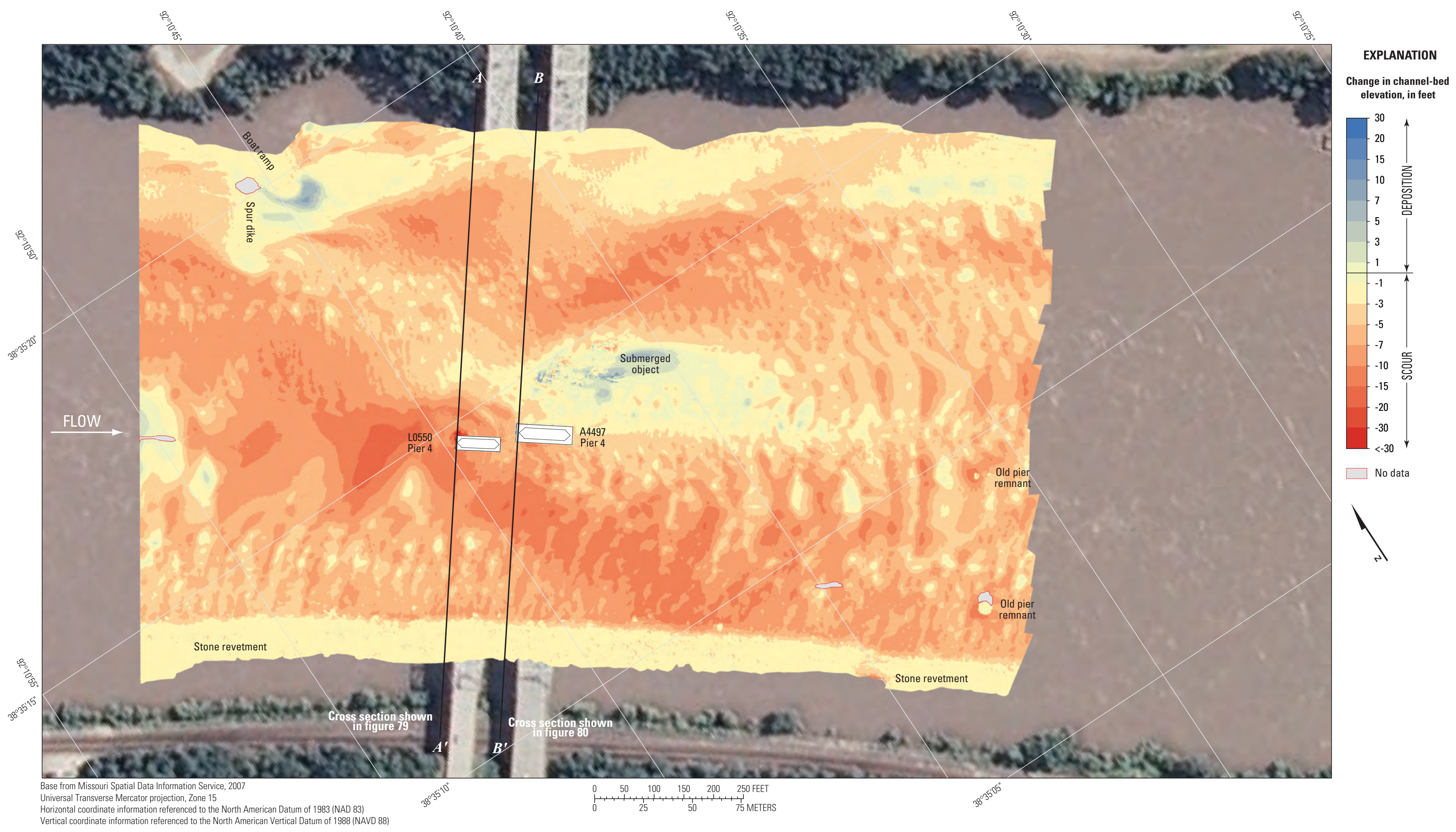

Figure 84. Difference between surfaces created from bathymetric surveys of the Missouri River channel in the vicinity of structures L0550 and A4497 on U.S. Highway 54 at Jefferson City, Missouri, on March 1, 2011 , and July 27, 2011. 


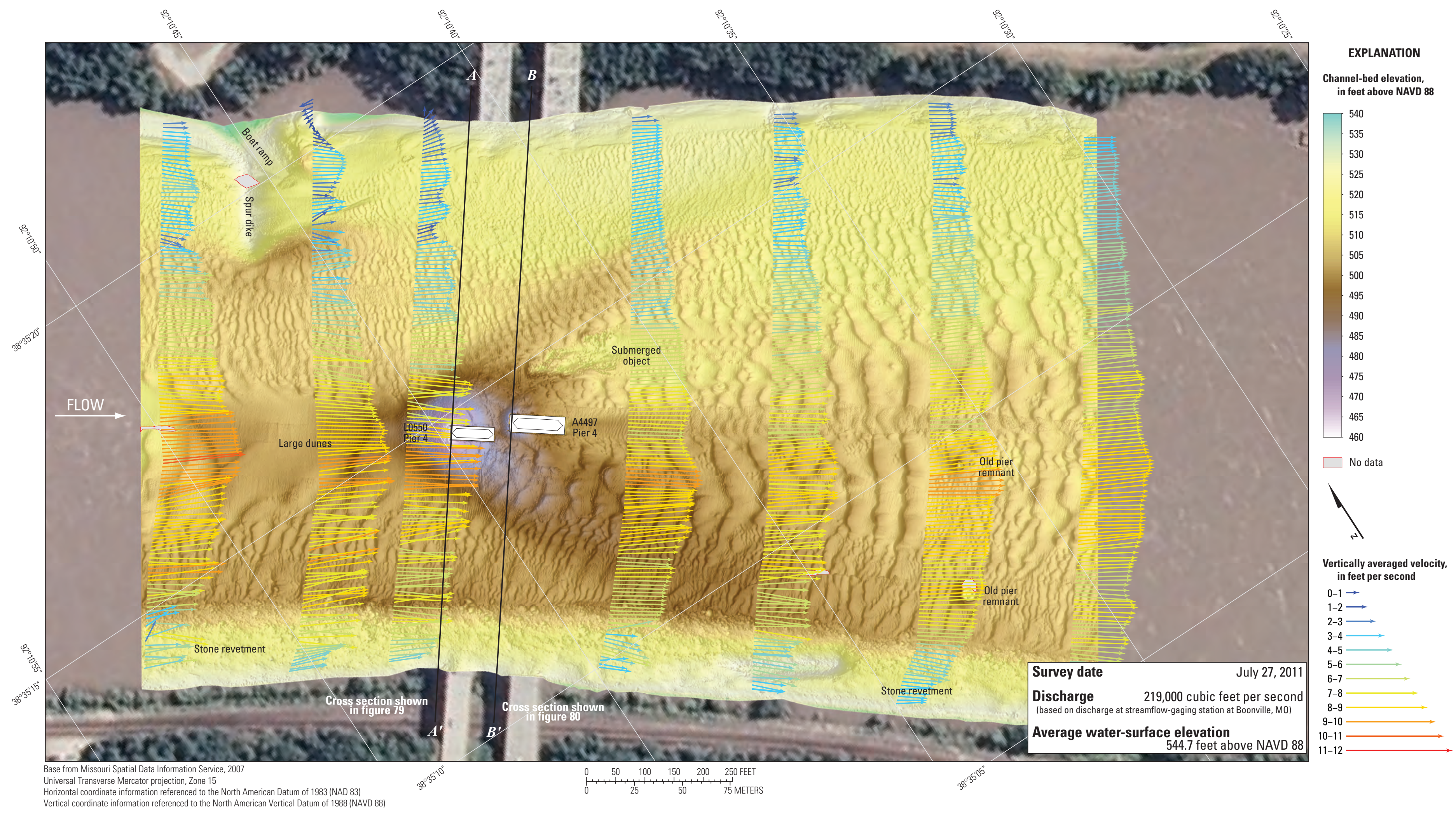

Figure 85. Bathymetry and vertically averaged velocities of the Missouri River channel in the vicinity of structures L0550 and A4497 on U.S. Highway 54 at Jefferson City, Missouri. 


\section{Structure A6288 on State Highway 19 at Hermann, Missouri}

Structure A6288 (site 21) on State Highway 19 crosses the Missouri River at RM 97.9 at Hermann, Missouri, east of Jefferson City and west of St. Louis (fig. 1). The site was surveyed on July 28, 2011, and the average water-surface elevation of the river in the survey area, determined by the RTK GPS tide solution, was $504.2 \mathrm{ft}$ (table 5). Flow on the Missouri River was about $215,000 \mathrm{ft}^{3} / \mathrm{s}$ during the survey, according to the streamgage at Hermann, Missouri (table 5).

The survey area was about $1,840 \mathrm{ft}$ long and about $1,400 \mathrm{ft}$ wide, extending from bank to bank in the main channel (fig. 86). The upstream end of the survey area was about $690 \mathrm{ft}$ upstream from the centerline of structure A6288 at pier 5 (fig. 86), and piers 4 through 6 were in the water and away from the banks. The channel-bed elevations ranged from about 465 to $485 \mathrm{ft}$ for most of the surveyed area (5 to 95 percentile range of the bathymetric data), except in the scour hole downstream from the upstream left (north) longitudinal spur dike which had a local minimum channel-bed elevation of about $449 \mathrm{ft}$ (fig. 86). A thalweg was present along the left (north) bank throughout the reach that was approximately $15 \mathrm{ft}$ deeper than the tops of the dunes in the middle of the channel (fig. 86). A series of medium to large dunes were present in the middle of the channel, and numerous medium and small dunes and ripples were present throughout the rest of the channel (fig. 86). Longitudinal spur dikes were present on the left (north) bank, and a rock outcrop, spur dikes, and stone revetment were present on the right (south) bank (fig. 86).

Minor scour holes were observed near all of the main channel piers in water. In the vicinity of main channel pier 6 (fig. 86), the scour hole had a minimum channel-bed elevation of about $467 \mathrm{ft}$ (table 8), about $25 \mathrm{ft}$ above the elevation of the bottom of the pier seal course of $442.00 \mathrm{ft}$ (fig. 87; table 8). The minor scour hole near pier 5 had a minimum channelbed elevation of about $464 \mathrm{ft}$ (table 8), about $20 \mathrm{ft}$ above the elevation of the bottom of the pier seal course of $444.50 \mathrm{ft}$ (fig. 87; table 8); this hole was difficult to discern from nearby dunes and ripples, but the downstream top of the footing was evident (figs. 86, 87). The moderate scour hole near pier 4 had a minimum channel-bed elevation of about $462 \mathrm{ft}$ (table 8), about $11 \mathrm{ft}$ above the elevation of the bottom of the pier seal course of $451.50 \mathrm{ft}$ (fig. 87; table 8); the upstream top of the footing was evident at this pier (figs. 86, 87). Information from bridge plans indicates that piers 4 through 6 are founded on shafts drilled as much as $27 \mathrm{ft}$ into bedrock, with about $66 \mathrm{ft}$ of bed material between the bottom of the scour hole and bedrock at pier 6 , about $51 \mathrm{ft}$ of material at pier 5 , and about $19 \mathrm{ft}$ of material at pier 4 (fig. 87; table 8). The surveyed bed generally was similar to the original ground line from bridge plans (2001), with localized areas of scour near pier 6 and to the right of pier 4 (fig. 87).

The vertically averaged velocity vectors indicate mostly uniform flow throughout most of the channel, ranging from about 4 to $8 \mathrm{ft} / \mathrm{s}$ (fig. 88), except behind the longitudinal spur dike on the upstream left (north) bank. Moderate turbulence was observed throughout the channel, with localized velocity spikes as high as $11 \mathrm{ft} / \mathrm{s}$ (fig. 88). Local flow reversal and substantial turbulence were observed behind the longitudinal spur dike on the left bank (fig. 88). The bridge piers were skewed to flow, but caused little to no evident turbulence downstream (fig. 88).

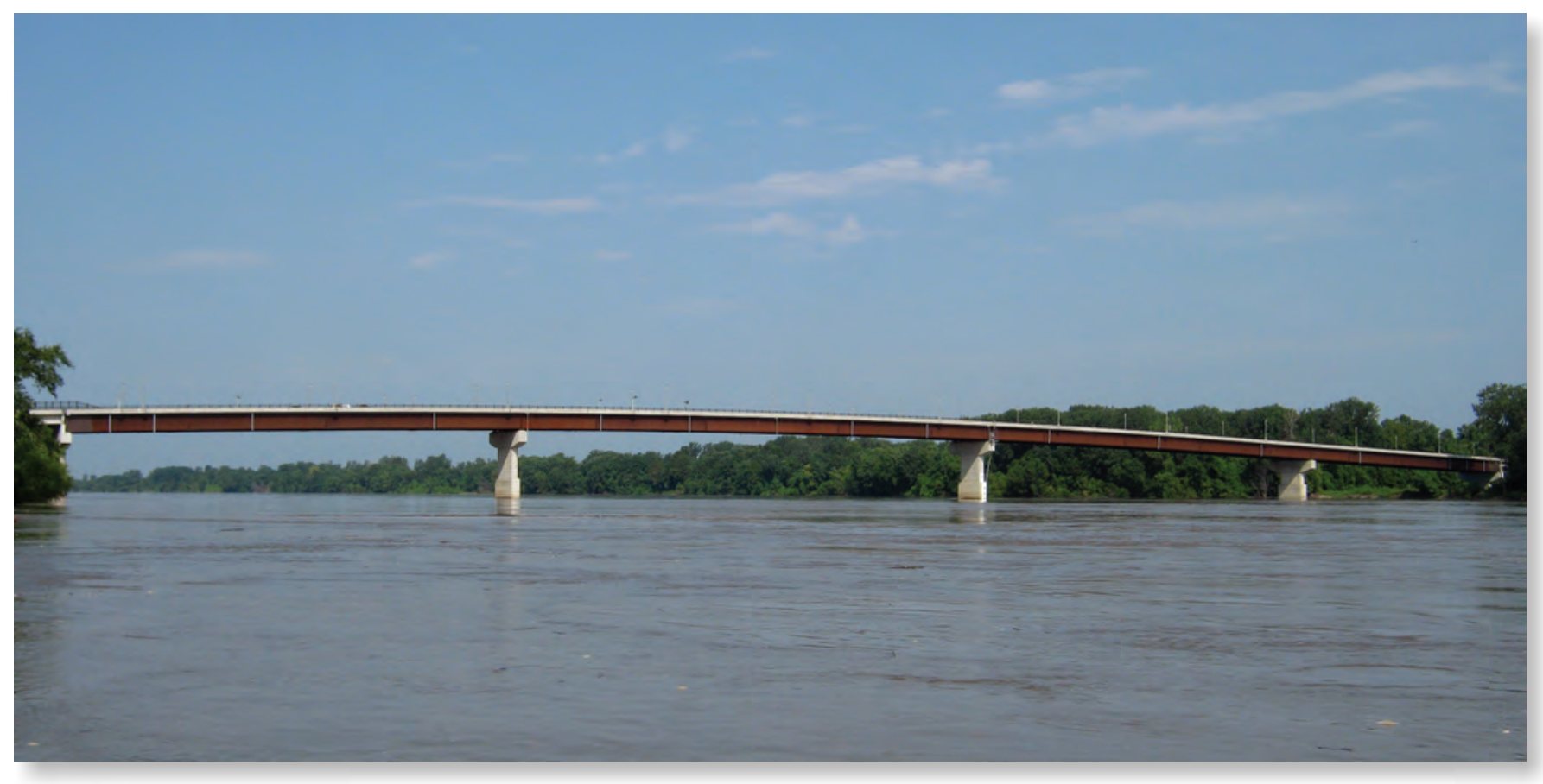

Structure A6288 on State Highway 19 at Hermann, Missouri. Photograph by Joseph Richards, USGS. 


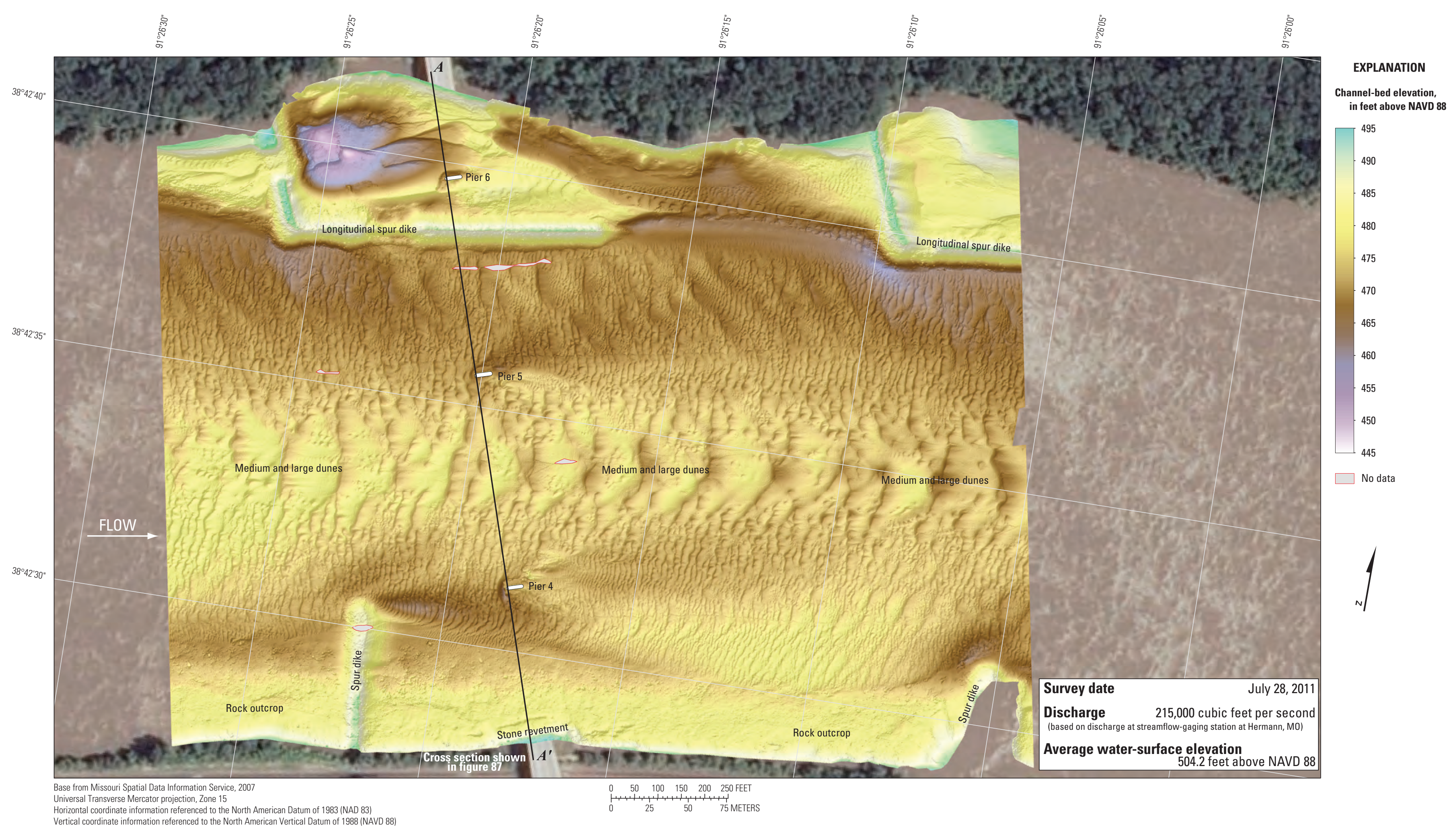

Figure 86. Bathymetric survey of the Missouri River channel in the vicinity of structure A6288 on State Highway 19 at Hermann, Missouri. 


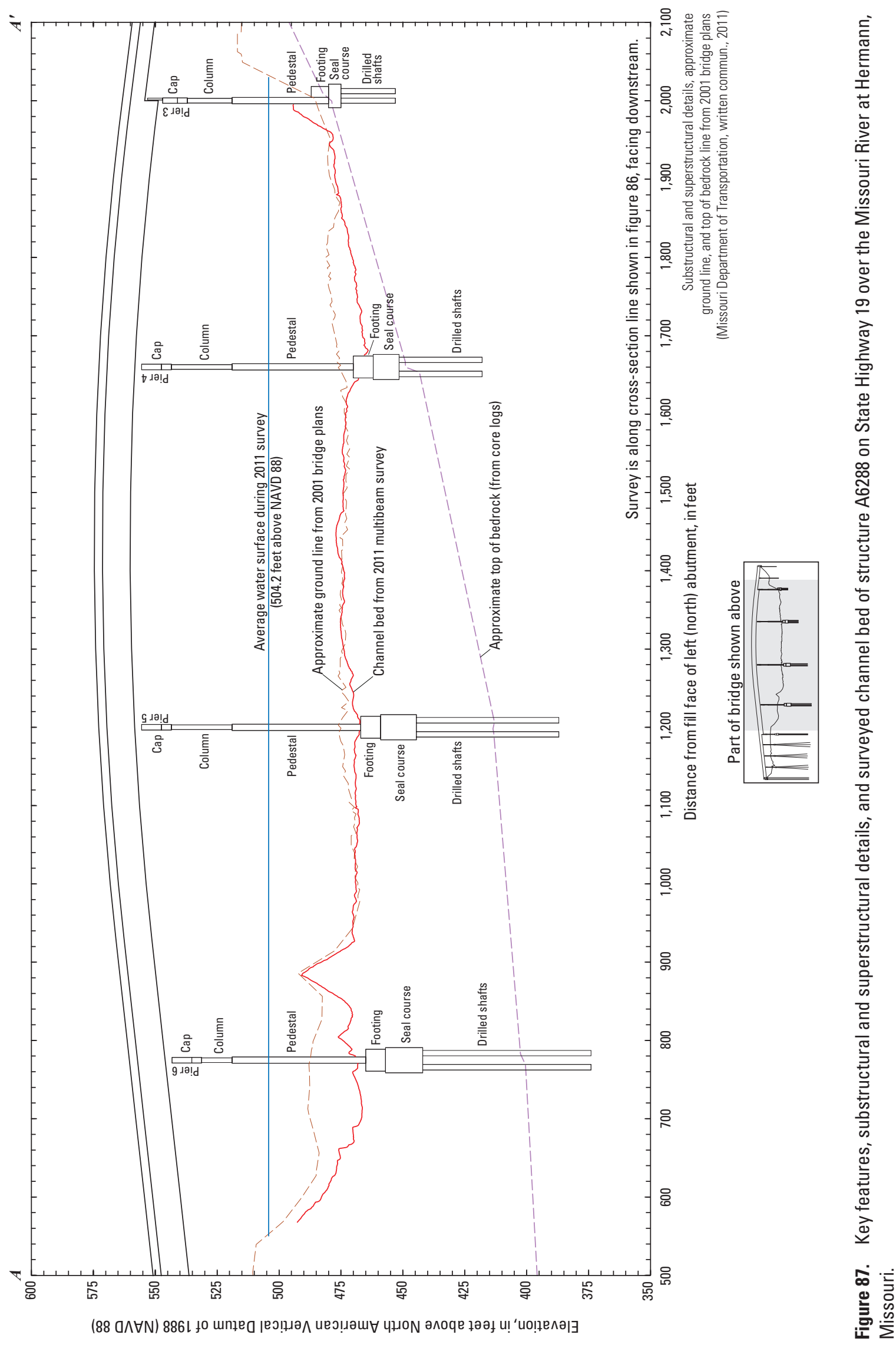




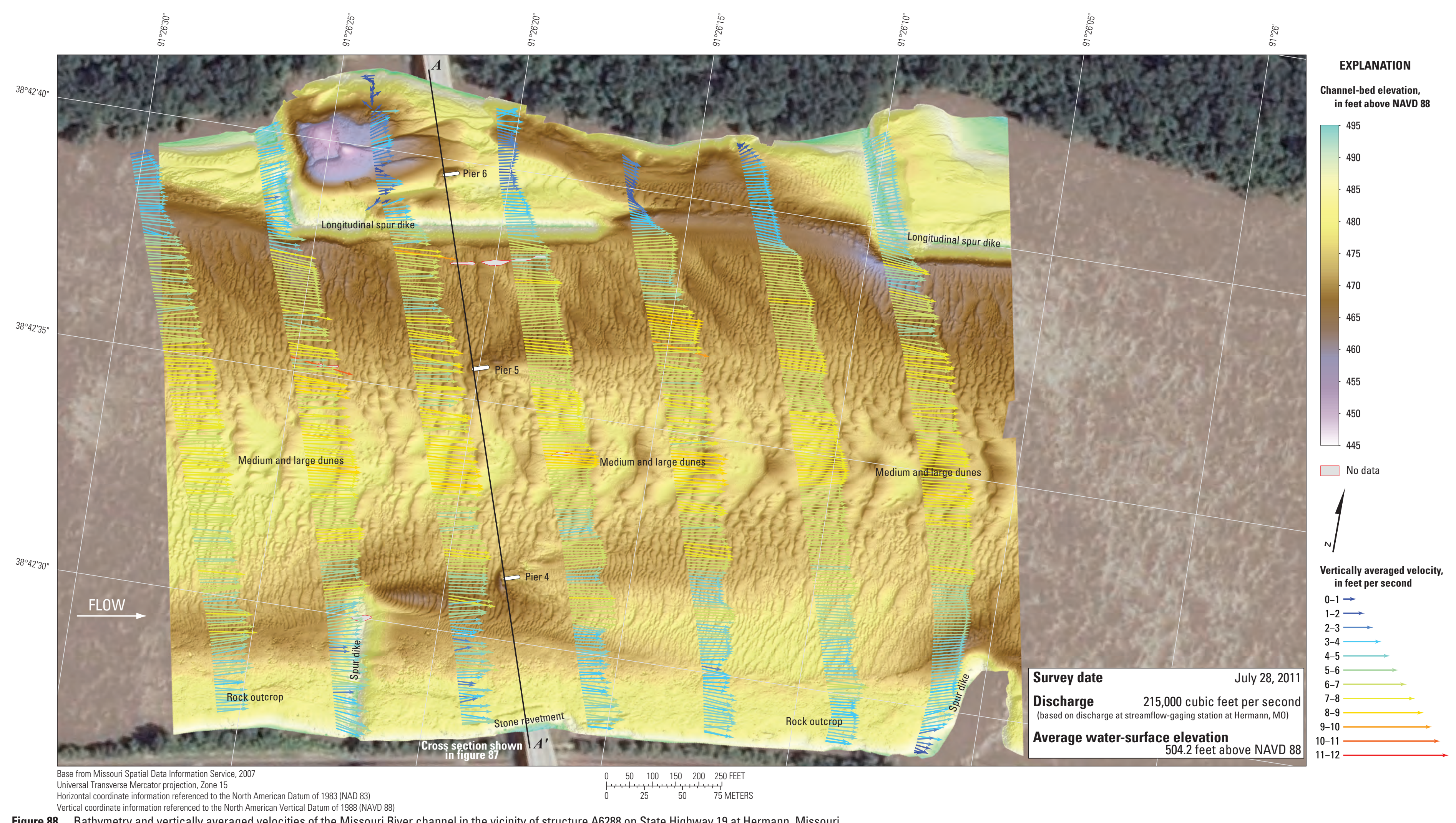

Figure 88. Bathymetry and vertically averaged velocities of the Missouri River channel in the vicinity of structure A6288 on State Highway 19 at Hermann, Missouri. 


\section{Structure K0969 on State Highway 47 at Washington, Missouri}

Structure K0969 (site 22) on State Highway 47 crosses the Missouri River at RM 67.6 at Washington, Missouri, east of Hermann and west of St. Louis (fig. 1). The site was surveyed on July 27,2011 , and the average water-surface elevation of the river in the survey area, determined by the RTK GPS tide solution, was $476.8 \mathrm{ft}$ (table 5). Flow on the Missouri River was about $214,000 \mathrm{ft}^{3} / \mathrm{s}$ during the survey, according to the streamgage at Hermann, Missouri (table 5).

The survey area was about 1,640 ft long and about $1,480 \mathrm{ft}$ wide, extending from bank to bank in the main channel (fig. 89). The upstream end of the survey area was about $570 \mathrm{ft}$ upstream from the centerline of structure K0969 (fig. 89), and piers 4 through 6 were in the water. The channel-bed elevations ranged from about 439 to $458 \mathrm{ft}$ for most of the surveyed area (5 to 95 percentile range of the bathymetric data), except in the scour hole at pier 5 and downstream from the downstream left (north) spur dike, which had a local minimum channel-bed elevation of about $417 \mathrm{ft}$ (fig. 89). A thalweg was present along the right (south) bank throughout the reach (fig. 89). A few medium dunes were present in the middle of the upstream channel, with numerous medium and small dunes and ripples throughout the rest of the channel (fig. 89). There appeared to be a rock outcrop on the right (south) bank, and longitudinal and lateral spur dikes were present on the right (south) bank with a single spur dike on the left (north) bank in the survey area (fig. 89).

Scour holes were observed near piers 5 and 6 . There was a substantial scour hole in the vicinity of main channel pier 5 (fig. 89), with a minimum channel-bed elevation of about $423 \mathrm{ft}$ (table 8), about $23 \mathrm{ft}$ below the average channelbed elevation upstream from the pier (fig. 90; table 8 ). The moderate scour hole near pier 6 had a minimum channel-bed elevation of about $446 \mathrm{ft}$ (table 8 ), about $8 \mathrm{ft}$ below the average channel-bed elevation upstream from the pier (fig. 90; table 8); this hole was more difficult to discern from nearby dunes (figs. 89, 90). Information from bridge plans indicates that piers 5 and 6 are founded on caissons on bedrock, with about $56 \mathrm{ft}$ of bed material between the bottom of the scour hole and bedrock at pier 6 , and about $30 \mathrm{ft}$ of material at pier 5 (fig. 90; table 8). Pier 4 was embedded in the longitudinal spur dike, and the minimum channel elevation at the toe of the dike was about $448 \mathrm{ft}$ (figs. 89, 90; table 8). Pier 4 is founded on a footing on bedrock, and bedrock was exposed at the toe of the spur dike (fig. 90; table 8); however, the rock of the spur dike likely will limit or prevent a local scour hole near pier 4 . The surveyed bed generally was below the ground line from bridge modification plans (1993), with areas of substantial scour on the left side of the channel, near pier 5 , and between piers 4 and 5 (fig. 90).

The vertically averaged velocity vectors indicate moderate turbulence throughout the channel, with velocities ranging from about 3 to $9 \mathrm{ft} / \mathrm{s}$ (fig. 91). Localized velocity fluctuations as low as $2 \mathrm{ft} / \mathrm{s}$ and as high as $11 \mathrm{ft} / \mathrm{s}$ were observed (fig. 91). Local flow reversal and substantial turbulence were observed downstream from the various spur dikes on both banks (fig. 91). The bridge piers were aligned with flow, and caused little to no evident turbulence downstream (fig. 91).

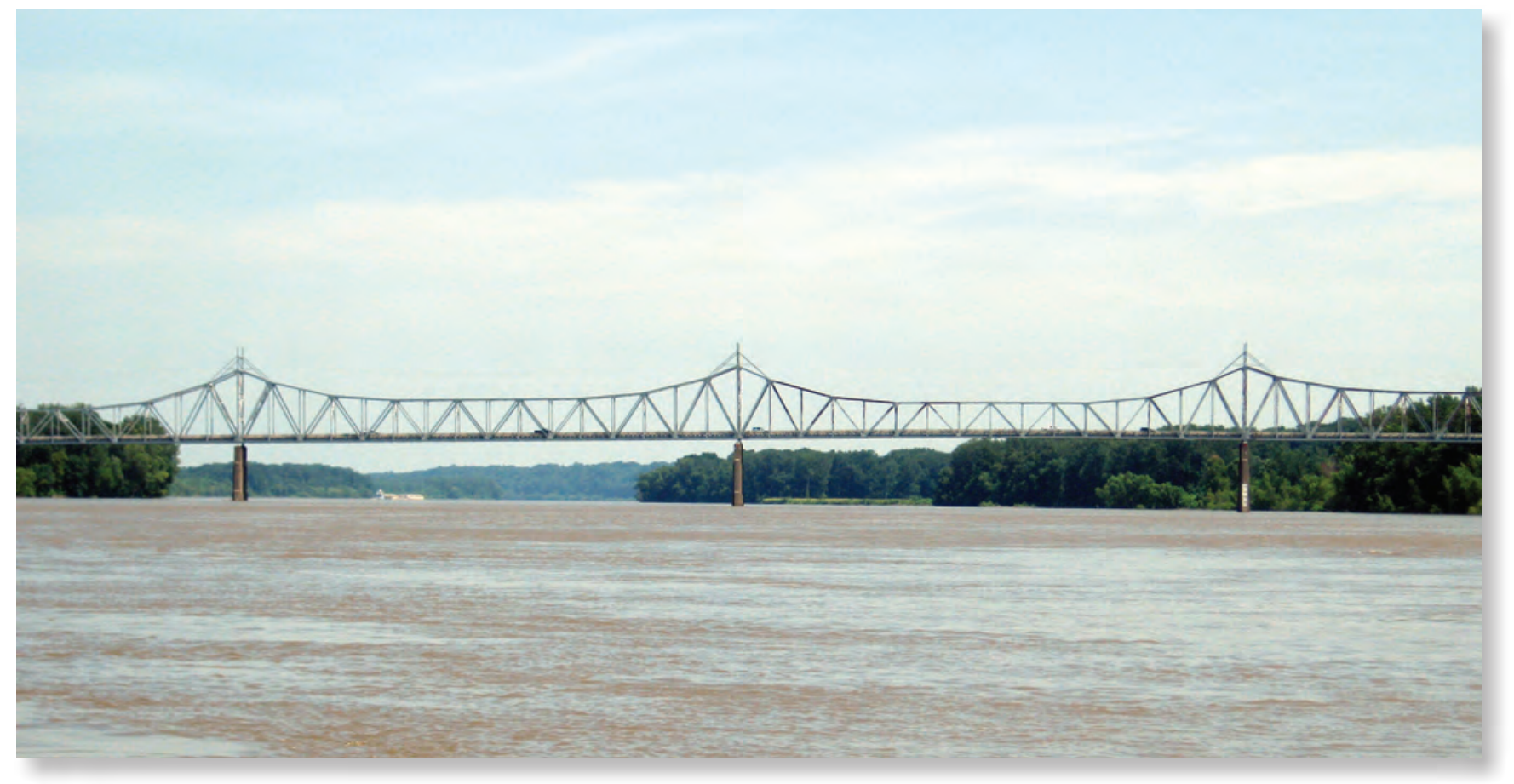

Structure K0969 on State Highway 47 at Washington, Missouri. Photograph by Joseph Richards, USGS. 


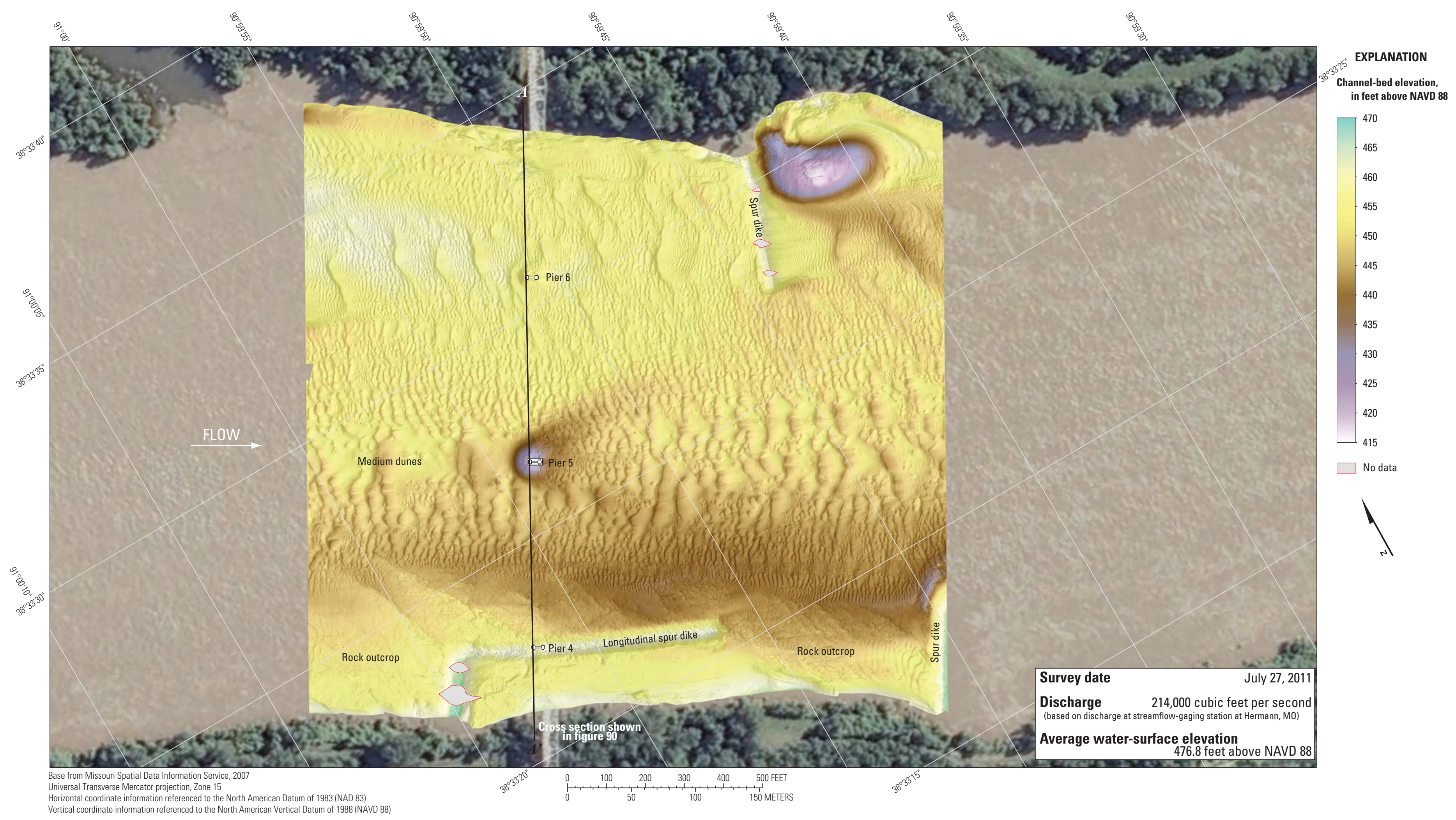

Figure 89. Bathymetric survey of the Missouri River channel in the vicinity of structure K0969 on State Highway 47 at Washington, Missouri. 


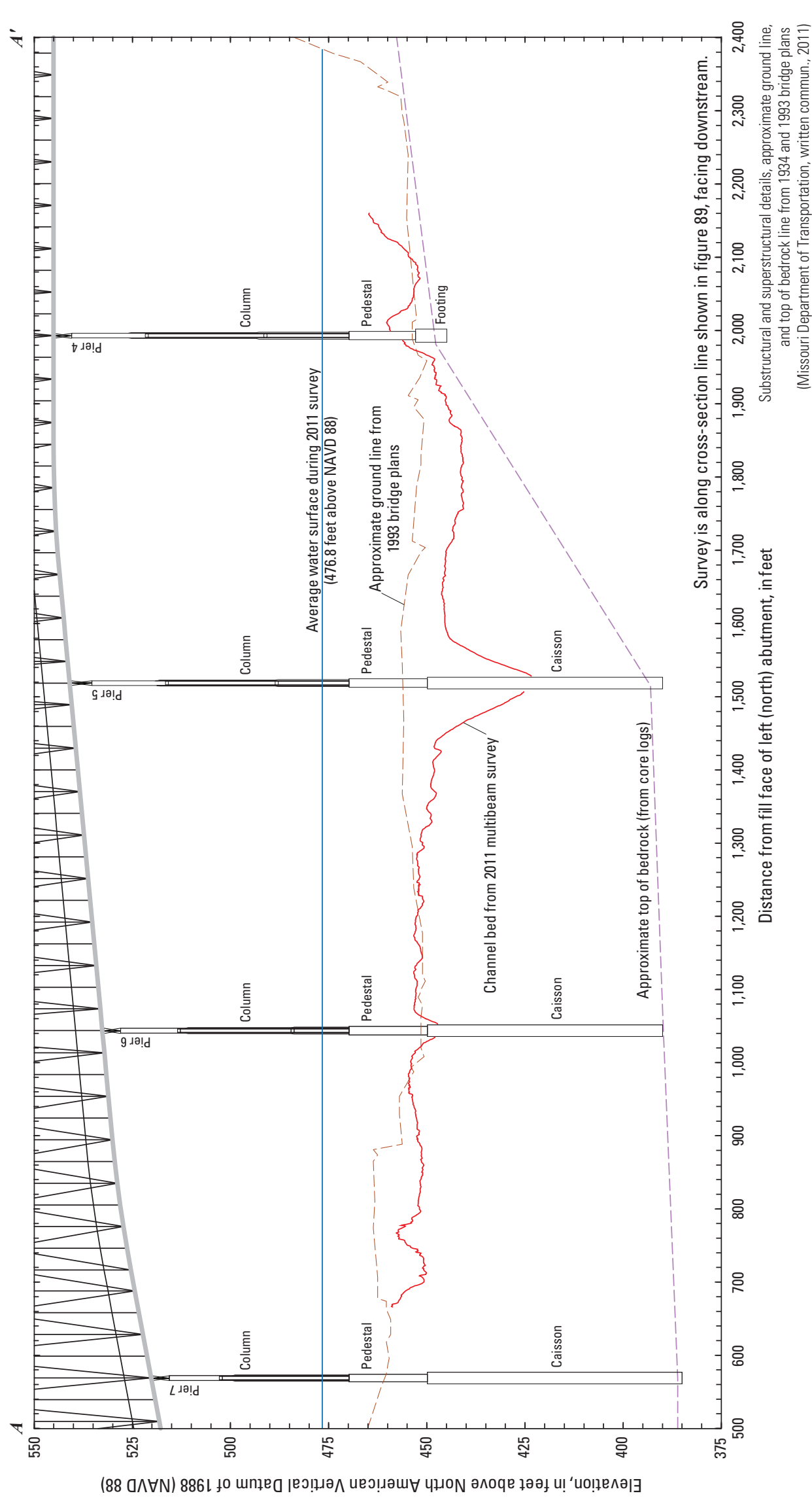

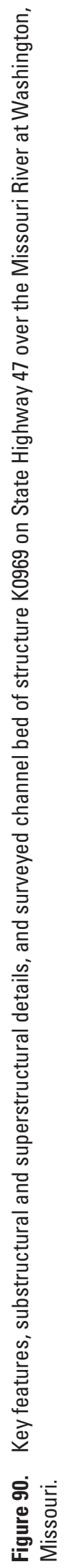




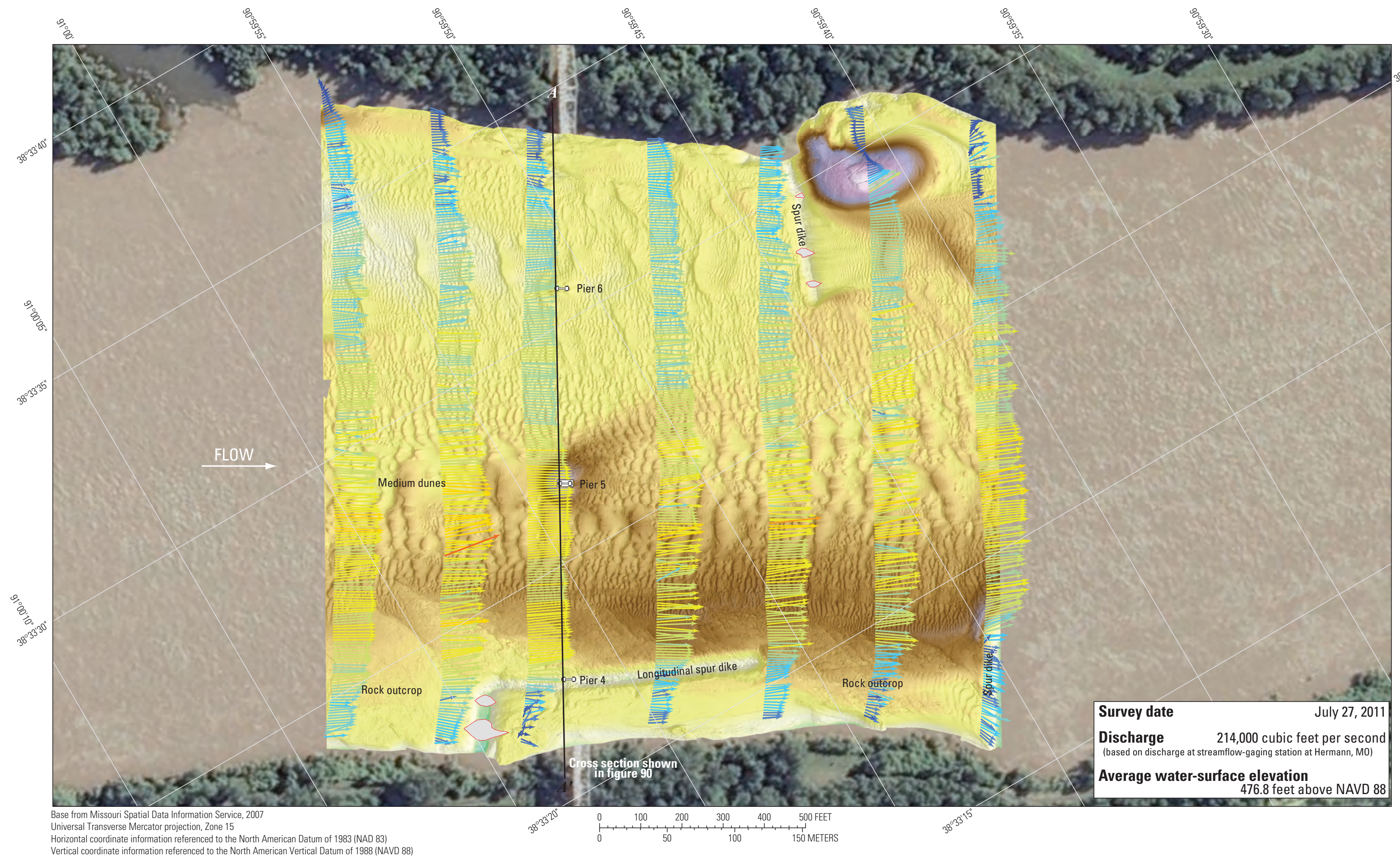

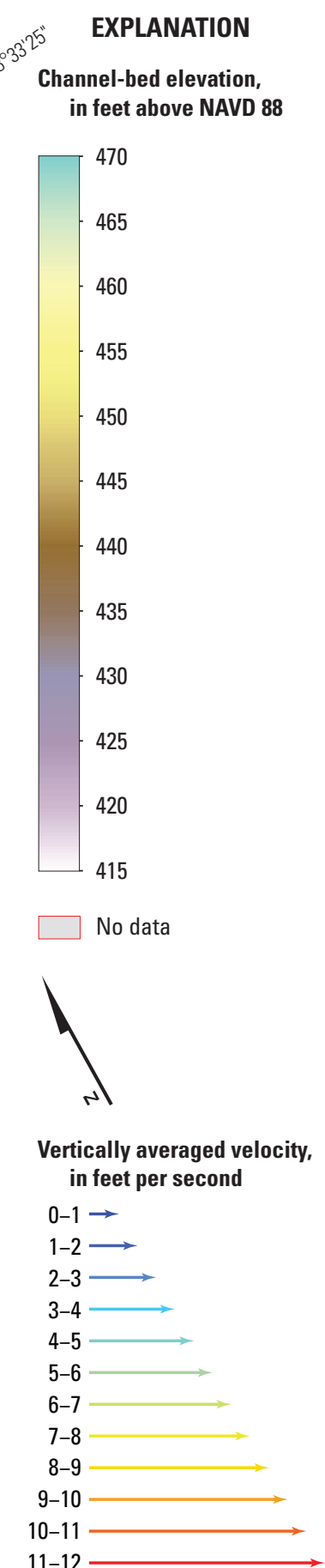

Figure 91. Bathymetry and vertically averaged velocities of the Missouri River channel in the vicinity of structure K0969 on State Highway 47 at Washington, Missouri. 


\section{Greater St. Louis Area}

There are five unique highway crossings of the Missouri River in the greater St. Louis area on the eastern side of Missouri (table 1; fig. 1). All of the sites have had previous bathymetric surveys in October 2010 (Huizinga, 2011).

\section{Structures A4017 and J1000 on U.S. Highway 40 near St. Louis, Missouri}

Structures A4017 and J1000 (site 23) are dual bridges on U.S. Highway 40 crossing the Missouri River at RM 43.9, on the western side of the greater St. Louis area (fig. 1). The site was surveyed on July 29, 2011, and the average watersurface elevation of the river in the survey area, determined by the RTK GPS tide solution, was $453.4 \mathrm{ft}$ (table 5). Flow on the Missouri River was about 220,000 $\mathrm{ft}^{3} / \mathrm{s}$ during the survey, according to the streamgage at St. Charles, Missouri (table 5).

The survey area was about $1,860 \mathrm{ft}$ long and about $1,640 \mathrm{ft}$ wide, extending from bank to bank in the main channel (fig. 92). The upstream end of the survey area was about $740 \mathrm{ft}$ upstream from the centerline of structures A4017 and J1000 (fig. 92). The channel-bed elevations ranged from about 414 to $437 \mathrm{ft}$ for most of the surveyed area ( 5 to 95 percentile range of the bathymetric data), except near the main channel piers of structures A4017 and J1000, near the ends of various spur dikes, and in the channel thalweg downstream from the bridges (fig. 92). The thalweg was not well defined in the upstream channel, but developed downstream from the bridges, and was about $10 \mathrm{ft}$ deeper than the channel bed in the middle of the channel (fig. 92). A series of medium dunes was present in the middle of the channel, with numerous other small dunes and ripples present throughout the rest of the channel (fig. 92). A rock outcrop and a longitudinal spur dike were present on the left (north) bank downstream from the bridges, and several other spur dikes were present on the both banks (fig. 92).

In the vicinity of the left main channel piers (pier 4 at both structures, fig. 92), a localized deep scour hole near the end of the spur dike had a minimum channel-bed elevation of about $411 \mathrm{ft}$. A debris raft between the piers on the left side made it impossible to acquire bathymetry data in the area upstream from pier 4 of downstream structure J1000. At the upstream nose of pier 4 of upstream structure A4017, a local scour hole had a minimum channel-bed elevation of approximately $416 \mathrm{ft}$ (table 9), about $13 \mathrm{ft}$ below the average channel bed immediately upstream from the pier (fig. 93). Downstream from pier 4 of downstream structure J1000, another localized deep scour hole had a minimum channel-bed elevation of about $407 \mathrm{ft}$ (fig. 92), which exposed the downstream right corner of the caisson of that pier. Information from bridge plans indicates that pier 4 of structure A4017 is founded on footings on bedrock, with about $11 \mathrm{ft}$ of bed material between the bottom of the upstream scour hole and bedrock at the upstream pier (fig. 93; table 9). Pier 4 of structure J1000 is founded on a caisson on bedrock, with the bottom of the local scour hole downstream from this pier was only about $2 \mathrm{ft}$ above the bottom of the caisson and bedrock (table 9); however, the local scour hole likely was the result of flow over the spur dike and not directly caused by the pier, and the piers essentially were embedded in the rock of the dike (fig. 94), which will limit or prevent additional scour near both left main channel piers and minimize the effect of the local scour hole on the stability of the piers.

In the vicinity of the central main channel piers (pier 5 at both structures, fig. 92), a discontinuous local scour hole had a minimum channel-bed elevation of approximately $403 \mathrm{ft}$ (fig. 92; table 9), about $16 \mathrm{ft}$ below the average channel bed immediately upstream from the piers. The minimum scour elevation was well above the bottom of the seal course elevation (383 ft) of the upstream pier (figs. 92, 93; table 9); however, the local scour hole exposed the upper part of the caissons of the downstream pier (figs. 92, 94). The central main channel piers were skewed to the approaching flow, which caused a wider scour hole with somewhat unique characteristics, similar to that observed at structures A4757 and L0568 on State Highway 291 in Kansas City. On the right (south) side of the upstream pier, the scour hole was slightly deeper, and extended beyond the downstream pier caissons, whereas the leeward left (north) side of the upstream pier had a local ridge of deposition (fig. 92). This deposition was eroded by the scour hole that formed upstream from the downstream pier caissons (fig. 92). Information from bridge plans indicates that pier 5 of upstream structure A4017 is founded on shafts drilled $26 \mathrm{ft}$ into bedrock, with about $43 \mathrm{ft}$ of bed material between the bottom of the scour hole and bedrock (fig. 93; table 9), whereas pier 5 of structure $\mathrm{J} 1000$ is founded on caissons on bedrock, with about $36 \mathrm{ft}$ of bed material between the bottom of the scour hole and bedrock (fig. 94; table 9). The exposed caissons of the downstream pier is clearly seen in a point cloud visualization of the multibeam depth points obtained during the survey (fig. 95).

In the vicinity of the right main channel piers (pier 6 at both structures, fig. 92), local scour was affected by rock piles upstream from each pier. A moderate scour hole near pier 6 of upstream structure A4017 had a minimum channel-bed elevation of about $414 \mathrm{ft}$ (table 9), but the rock piles upstream from the piers mitigated scour near the upstream nose of each pier (figs. 92, 93, 94). A minor scour hole near pier 6 of downstream structure $\mathrm{J} 1000$ had a minimum channel-bed elevation of about $418 \mathrm{ft}$ (figs. 92, 94; table 9). Information from bridge plans indicates that pier 6 of upstream structure A4017 is founded on shafts drilled $13 \mathrm{ft}$ into bedrock, with about $54 \mathrm{ft}$ of bed material between the bottom of the scour hole and bedrock (fig. 93; table 9). Pier 6 of structure J1000 is founded on caissons on bedrock, with about $58 \mathrm{ft}$ of bed material between the bottom of the scour hole and bedrock (fig. 94; table 9).

The difference between the survey on July 29, 2011, and the previous survey on October 18, 2010 (fig. 96) indicates widespread areas of scour and deposition throughout the reach from 2010 to 2011, with an average difference of $-0.38 \mathrm{ft}$ between the bathymetric surfaces (table 7). There was 
substantial deposition downstream from the spur dike on the left (north) bank near the left main channel piers (pier 4) and on the downstream right bank, whereas there was scour in the thalweg downstream from the bridges (fig. 96). In most of the channel, there was minor scour and deposition of less than $10 \mathrm{ft}$, with minimal net change between the surveys as indicated by the mean difference being near zero. The scour holes near pier 4 of upstream structure A4017 were of similar shape in the two surveys (fig. 93). Near the center main channel piers (pier 5), there was minor deposition near upstream structure A4017, and moderate scour near downstream structure J1000 (fig. 96). The scour hole near pier 5 of downstream structure J1000 was deeper and wider in 2011 than in 2010 (fig. 94). Near the right main channel piers (pier 6), there was moderate to substantial scour from a wider and deeper scour hole at upstream structure A4017 (fig. 94), with minor scour near downstream structure J1000 (fig. 96). The cross sections from the 2011 survey are similar to the 2010 survey at both bridges (figs. 93, 94), despite the water-surface elevation difference of more than $9 \mathrm{ft}$ and a flow difference of nearly $125,000 \mathrm{ft}^{3} / \mathrm{s}$ (table 7).

The vertically averaged velocity vectors indicate moderate to substantial turbulence throughout the reach, with velocities ranging from about 2 to $9 \mathrm{ft} / \mathrm{s}$ (fig. 97). Flow was angled to the left (north) for much of the reach because of the bend in the river, and there were numerous flow reversals downstream from the various spur dikes (fig. 97). Substantial turbulence was observed in the vicinity of pier 5 of both bridges, likely exacerbated by the piers being skewed to flow and in staggered formation (fig. 97).

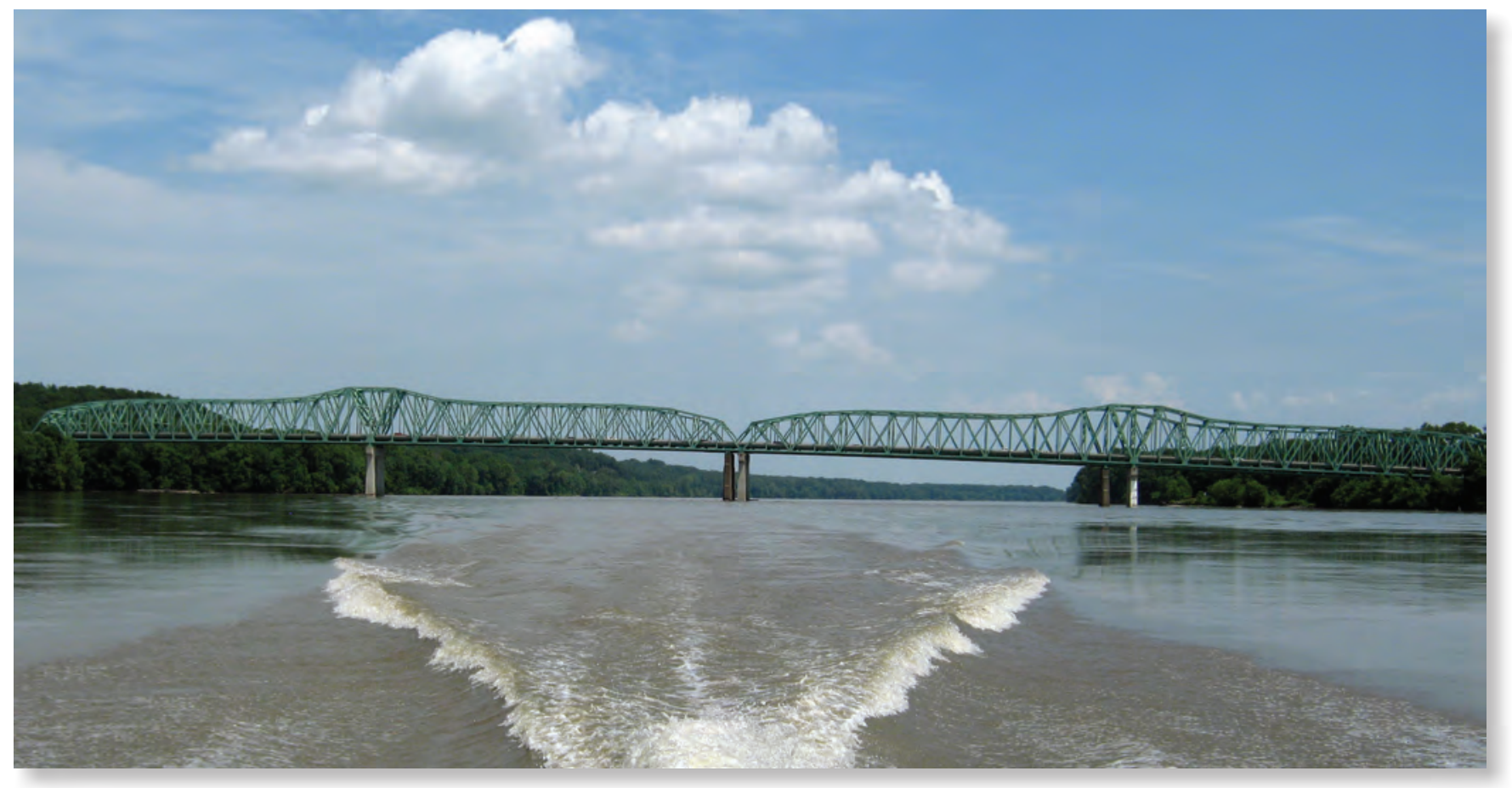

Structures A4017 and J1000 on U.S. Highway 40 near St. Louis, Missouri. Structure A4017 is in the foreground and J1000 is in the background. Photograph by Joseph Richards, USGS. 


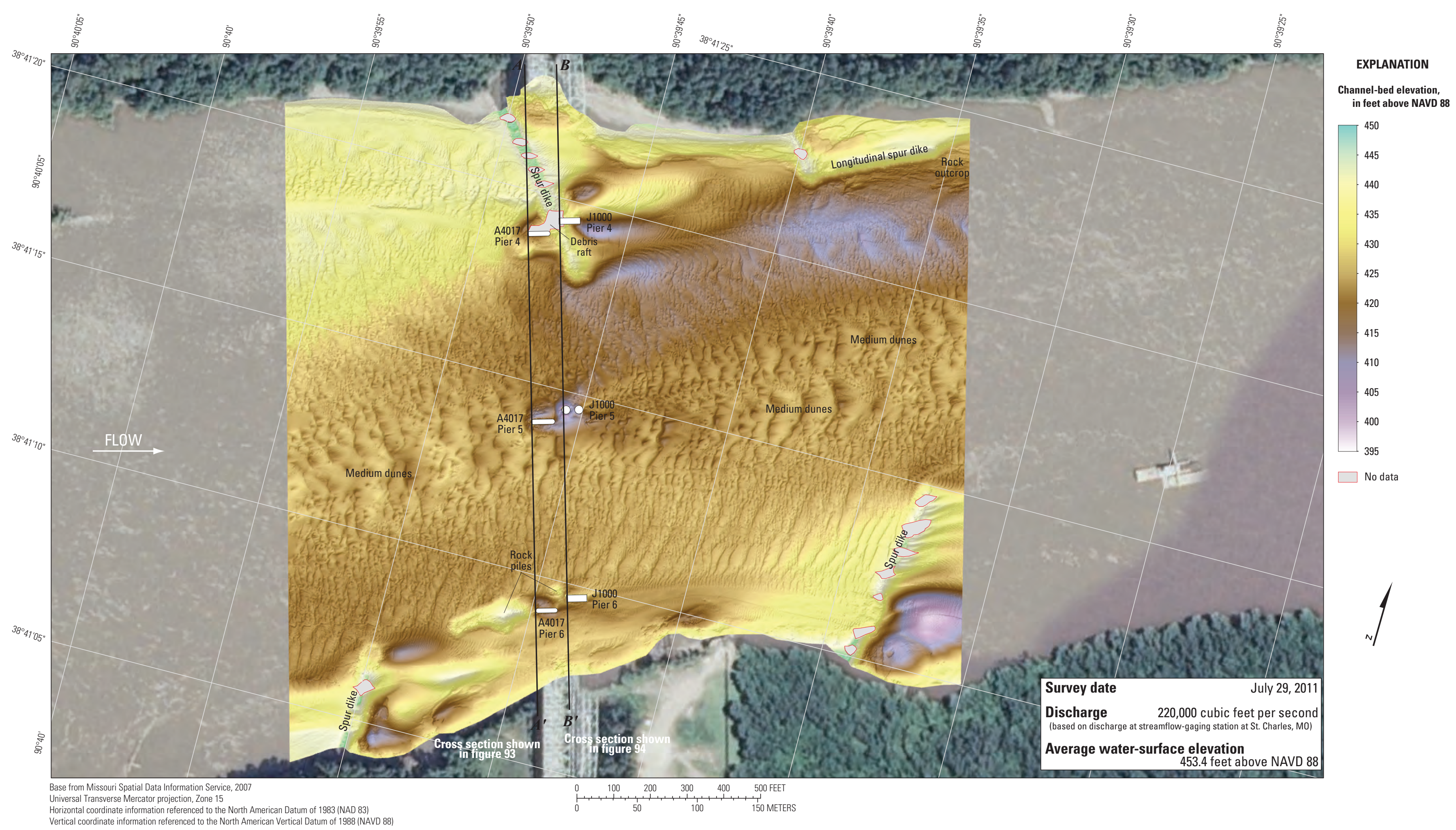

Figure 92. Bathymetric survey of the Missouri River channel in the vicinity of structures A4017 and J1000 on U.S. Highway 40 near St. Louis, Missouri. 


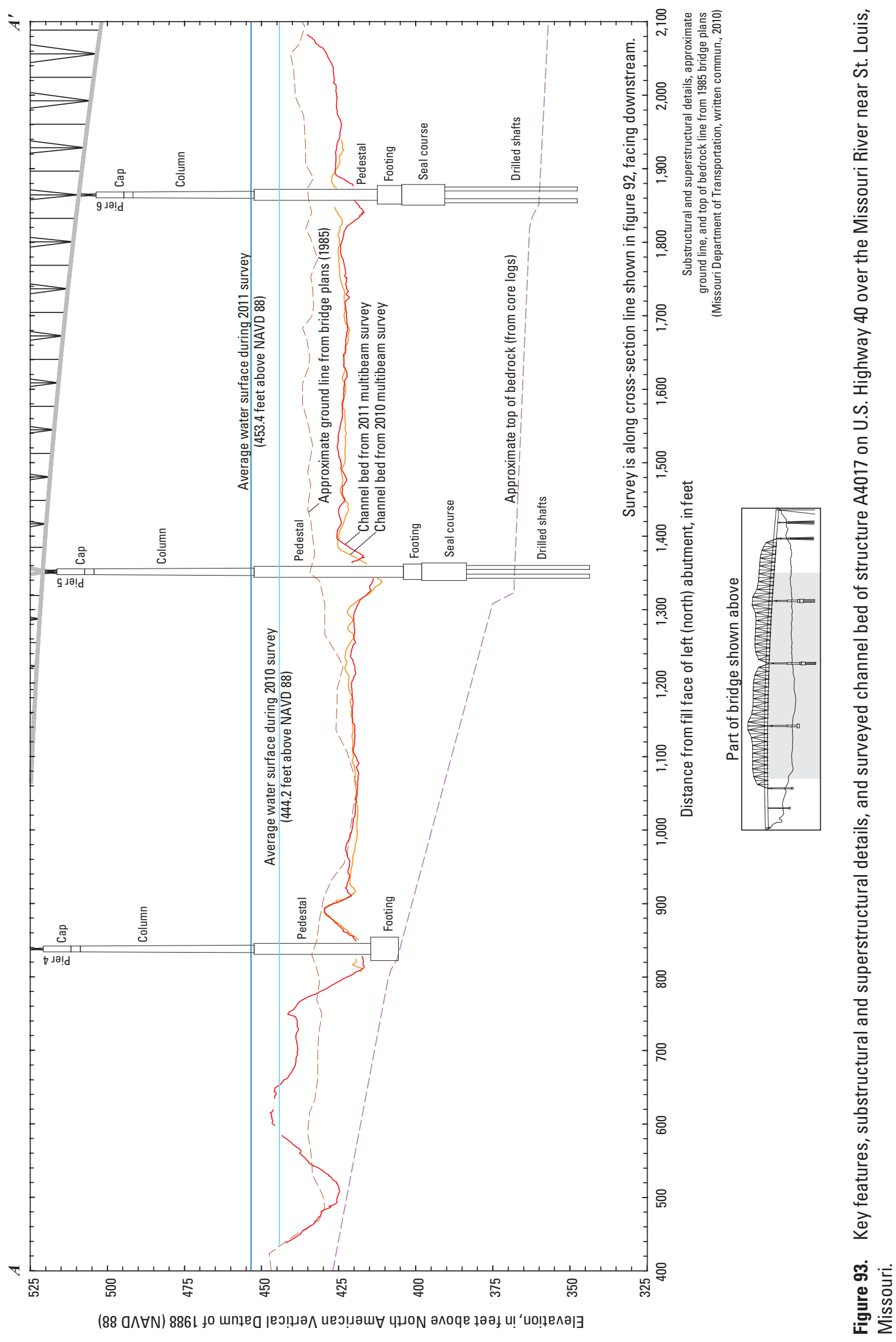




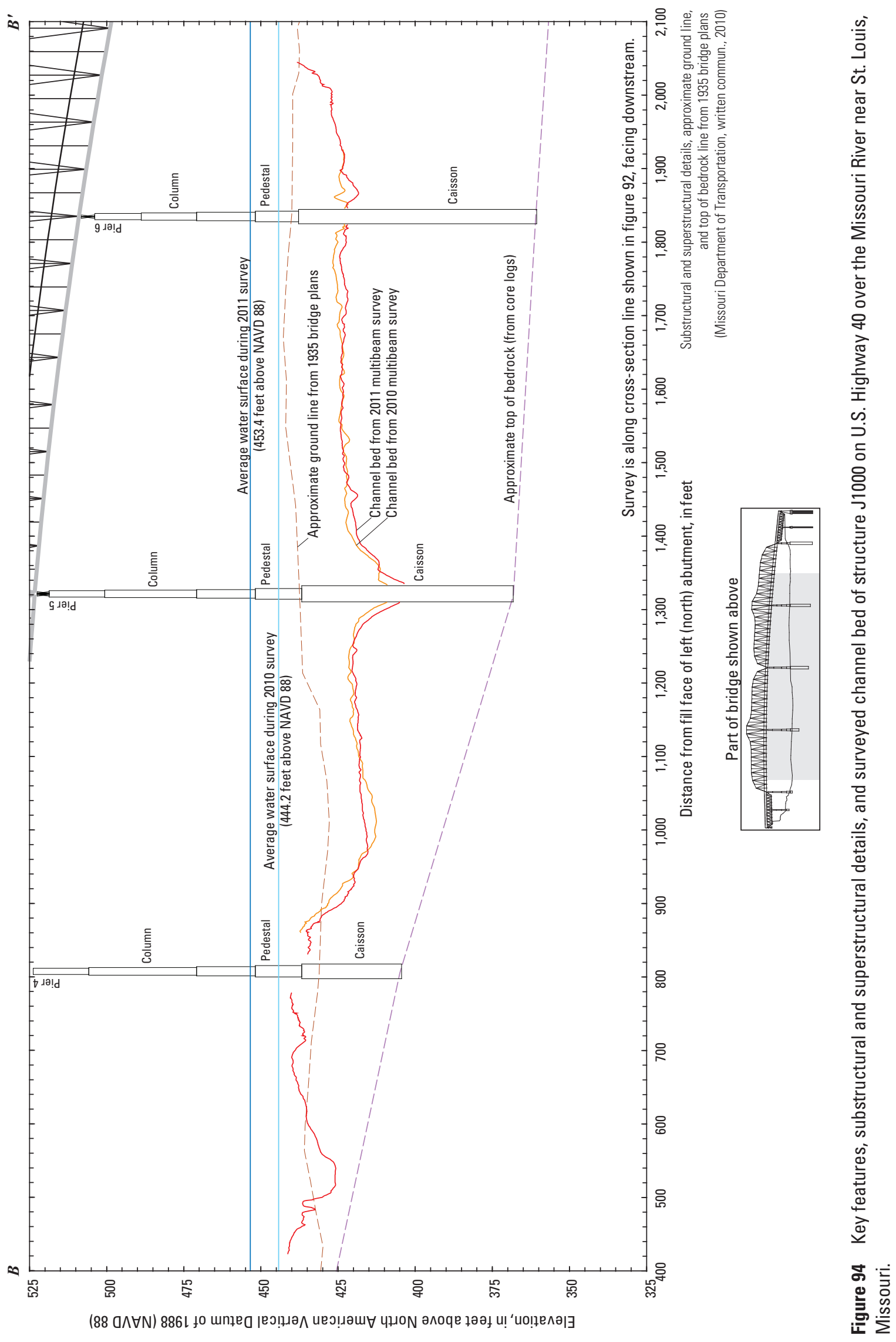




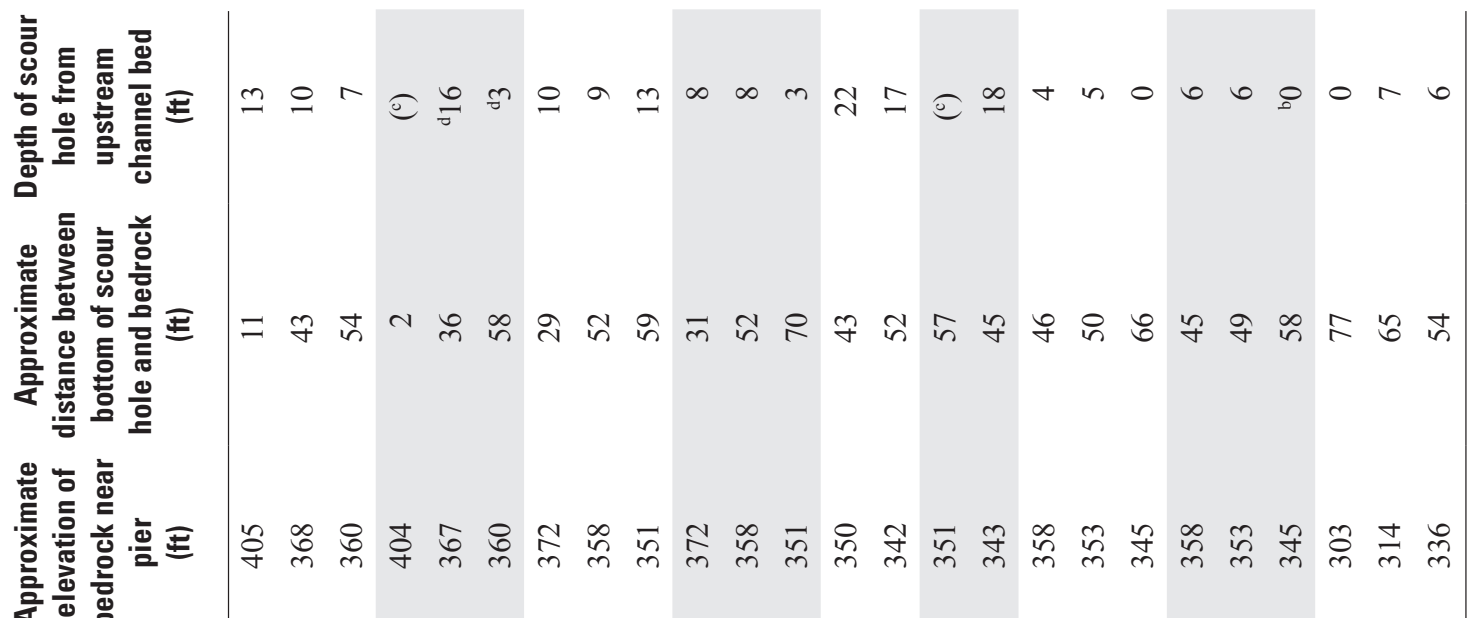

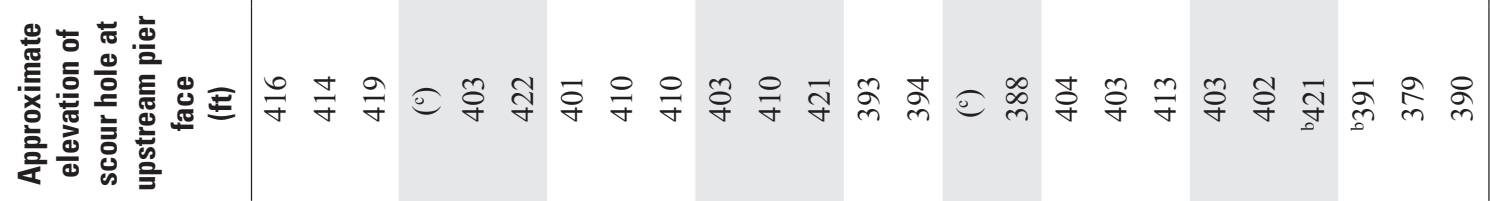

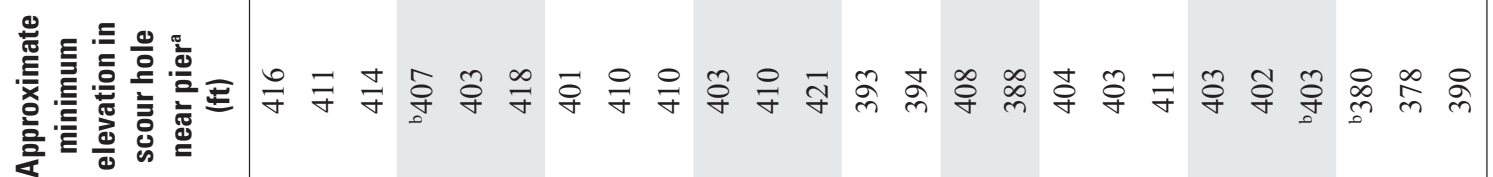

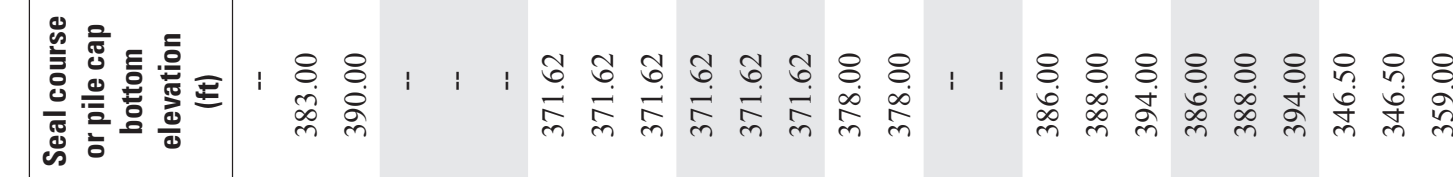

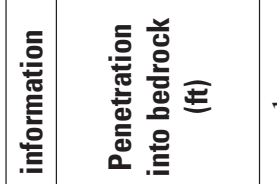

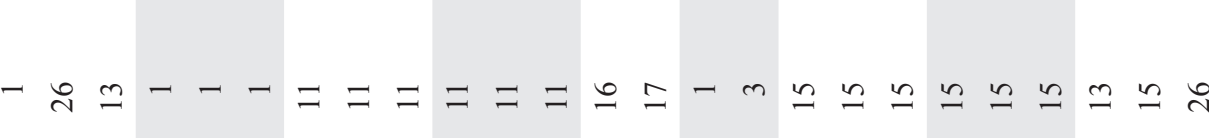

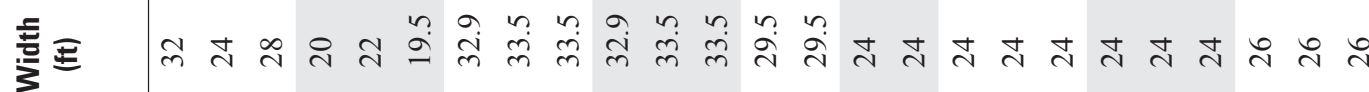

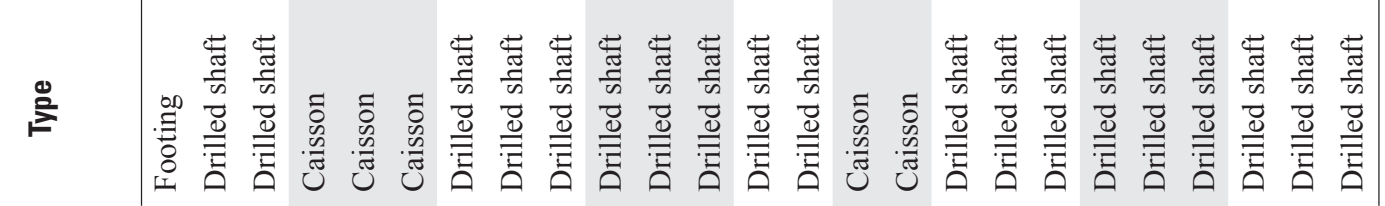
占高
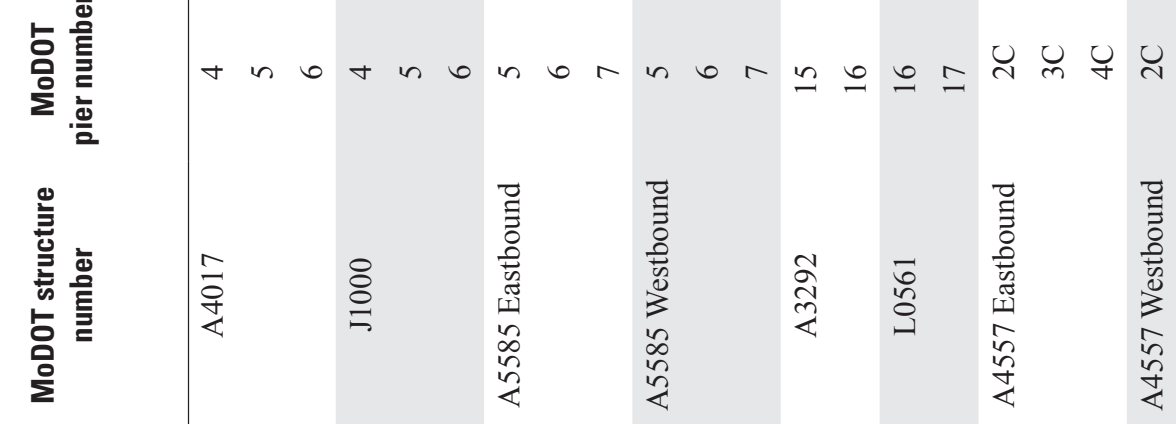

站言咅家

กิ

$\stackrel{+}{4}$

茨

ก 2 ก

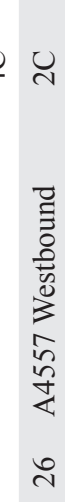

$y \circ=\simeq$

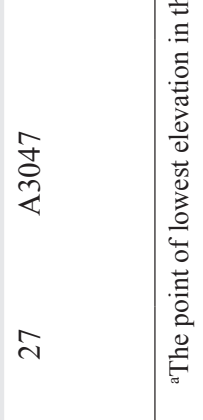

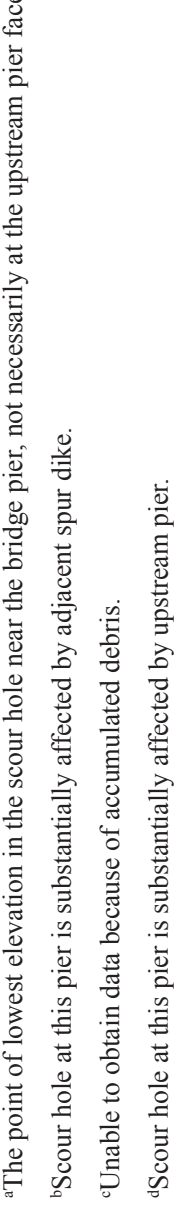




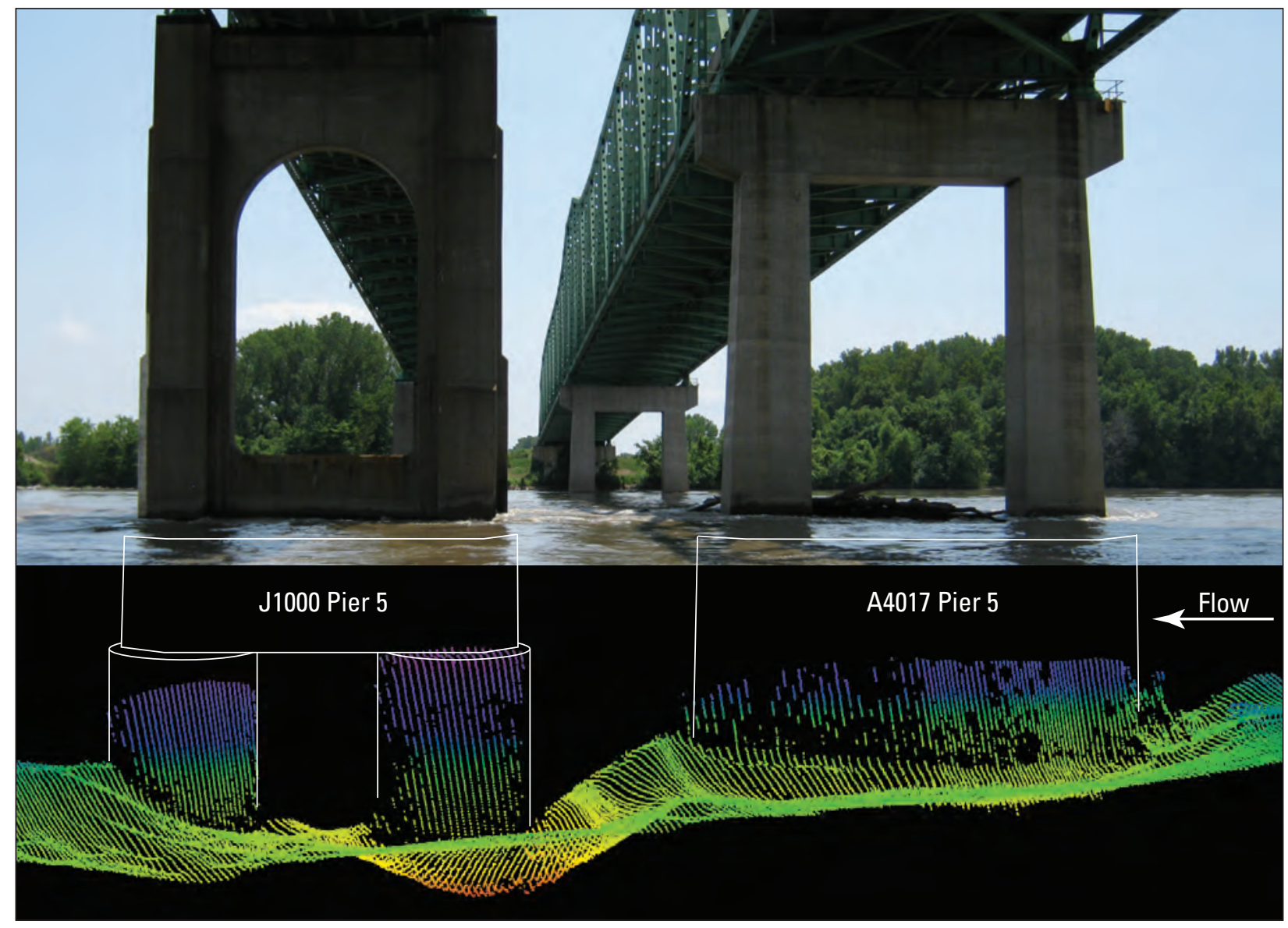

EXPLANATION

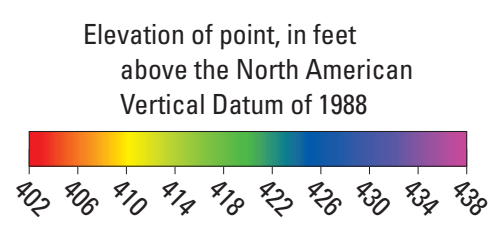

Figure 95. Point cloud visualization of the channel bed and left (north) side of the central main channel piers (pier 5) of structures A4017 and J1000 on U.S. Highway 40 over the Missouri River near St. Louis, Missouri. 


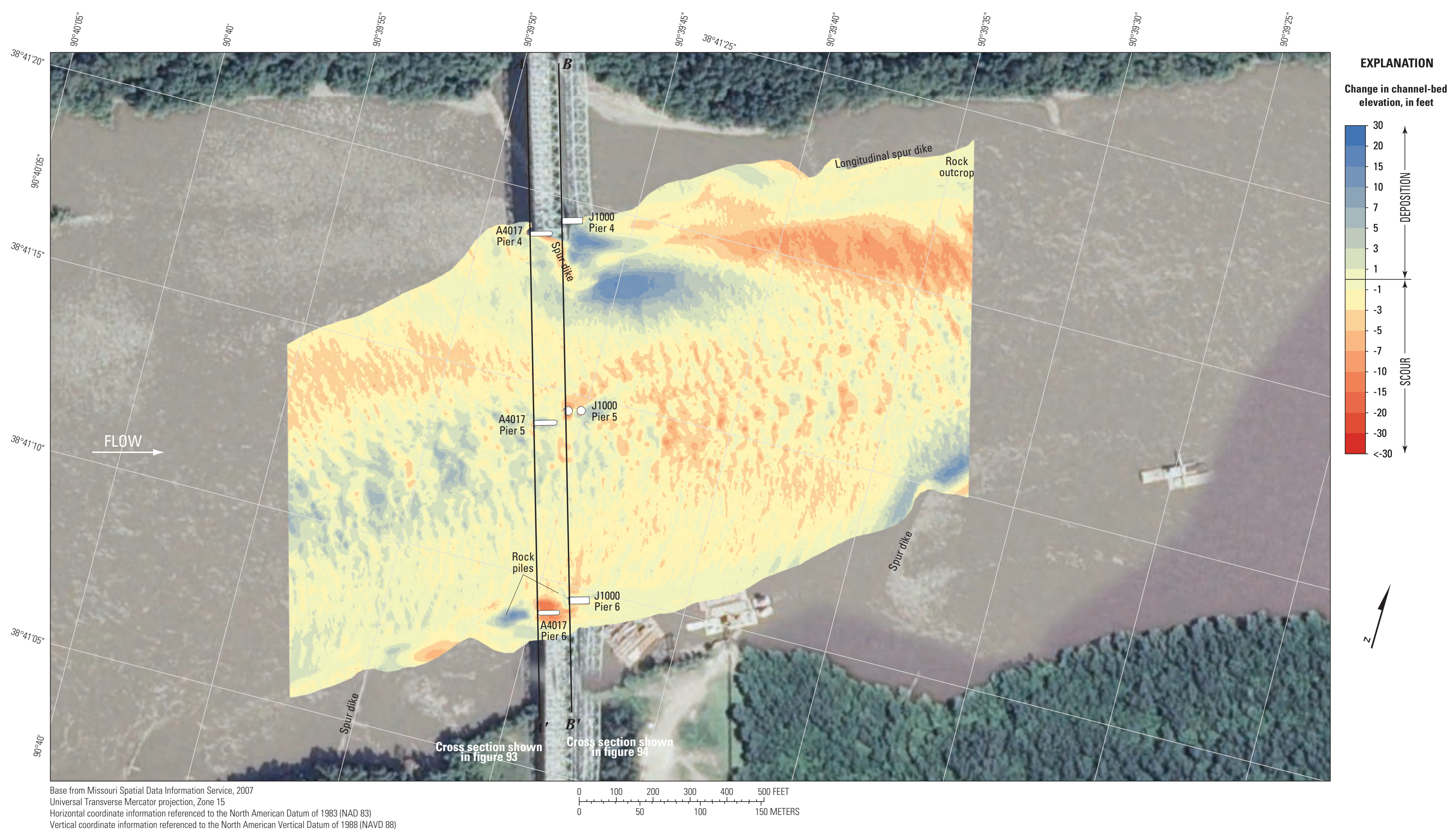

Figure 96. Difference between surfaces created from bathymetric surveys of the Missouri River channel in the vicinity of structures A4017 and J1000 on U.S. Highway 40 near St. Louis, Missouri, on October 18, 2010, and July 29, 2011. 


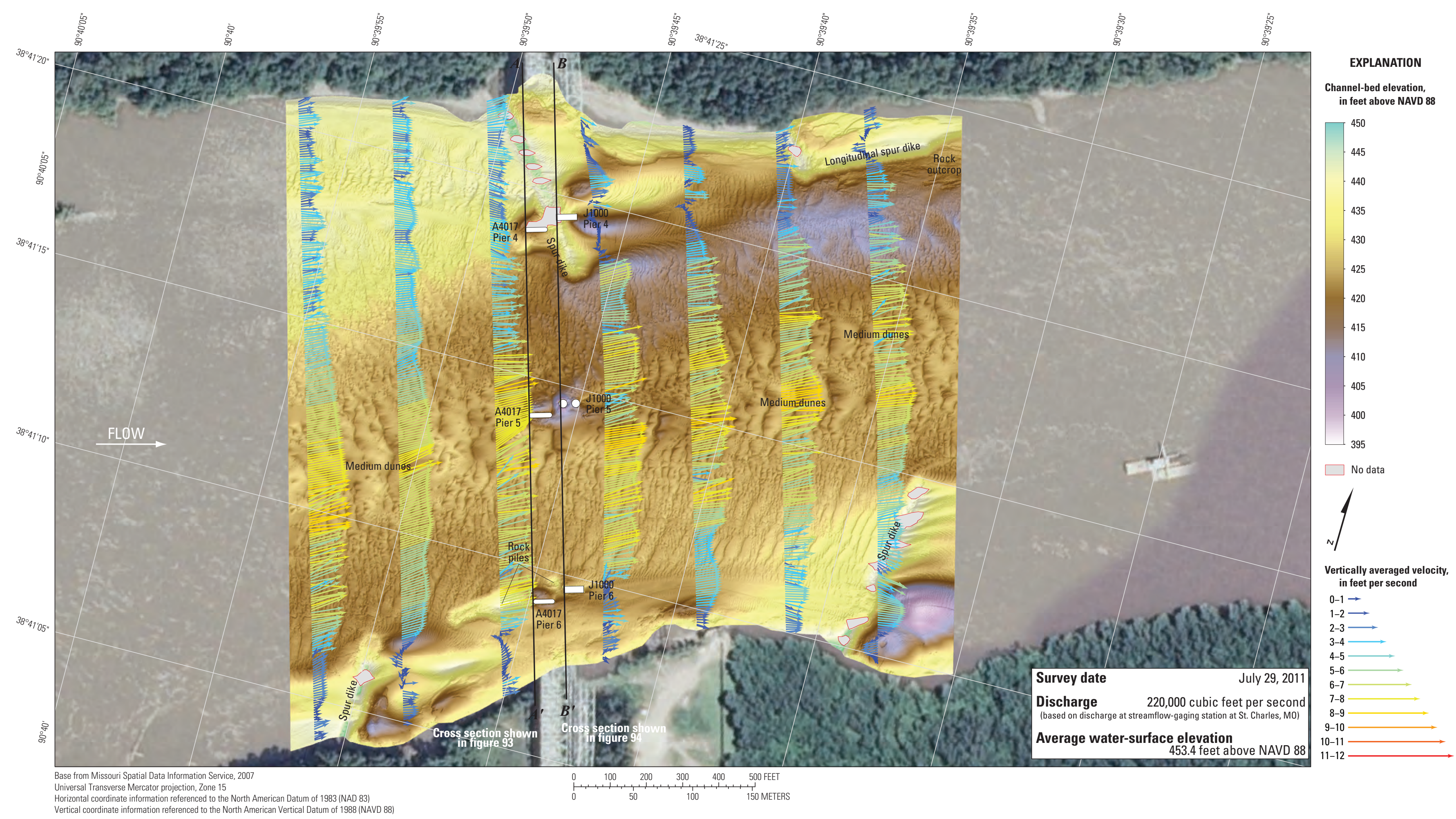

Figure 97. Bathymetry and vertically averaged velocities of the Missouri River channel in the vicinity of structures A4017 and J1000 on U.S. Highway 40 near St. Louis, Missouri. 


\section{Dual Bridge Structure A5585 on State Highway 364 near St. Louis, Missouri}

Structure A5585 (site 24) consists of twin bridges on State Highway 364 crossing the Missouri River at RM 32.7, on the west-central side of the greater St. Louis area (fig. 1). The site was surveyed on August 1, 2011, and the average water-surface elevation of the river in the survey area, determined by the RTK GPS tide solution, was $443.2 \mathrm{ft}$ (table 5). Flow on the Missouri River was about 224,000 $\mathrm{ft}^{3} / \mathrm{s}$ during the survey, according to the streamgage at St. Charles, Missouri (table 5).

The survey area was about 1,640 ft long and averaged about $1,250 \mathrm{ft}$ wide, extending from bank to bank in the main channel (fig. 98). The upstream end of the survey area was about $740 \mathrm{ft}$ upstream from the centerline of structure A5585 (fig. 98). The channel-bed elevations ranged from about 405 to $426 \mathrm{ft}$ for most of the surveyed area (5 to 95 percentile range of the bathymetric data), except along the channel thalweg where substantial dunes caused local minimum channel-bed elevations of about $396.5 \mathrm{ft}$ (fig. 98). The thalweg was along the outside of the river bend on the left (north) bank, and was about 15 to $25 \mathrm{ft}$ deeper than the channel bed in the middle of the channel (fig. 98). In addition to a series of medium to large dune features in the channel thalweg, there were numerous medium and small dunes and ripples throughout the rest of the channel (fig. 98). A rock outcrop was clearly present on the left (north) bank throughout the reach, with indications of exposure in the troughs of the upstream large dune features (fig. 98). A spur dike was present on the right (south) bank just upstream from the bridges (fig. 98).

Scour holes were present in the vicinity of the main channel piers of structure A5585 (fig. 98), and generally there was more substantial scour associated with the upstream (eastbound) piers than the downstream (westbound) piers. The scour hole at upstream (eastbound) pier 5 had a minimum channel-bed elevation of about $401 \mathrm{ft}$ (fig. 98; table 9), about $10 \mathrm{ft}$ below the average channel bed immediately upstream from the pier, whereas the scour hole at downstream (westbound) pier 5 had a minimum channel-bed elevation of about $403 \mathrm{ft}$ (fig. 98; table 9), about $8 \mathrm{ft}$ below the average channel bed immediately upstream from the pier. The scour holes at pier 6 had a minimum channel-bed elevation of about $410 \mathrm{ft}$ at both upstream and downstream piers (fig. 98; table 9), which was about $9 \mathrm{ft}$ below the average channel bed immediately upstream from the upstream pier and about $8 \mathrm{ft}$ below the average channel bed immediately upstream from the downstream pier. A moderate debris raft was present on the nose of upstream pier 7, which contributed to a scour hole with a minimum channel-bed elevation of about $410 \mathrm{ft}$ (fig. 98; table 9), about $13 \mathrm{ft}$ below the average channel bed immediately upstream from the pier. The scour hole at downstream pier 7 had a minimum channel-bed elevation of about $421 \mathrm{ft}$ (fig. 98; table 9), only about $3 \mathrm{ft}$ below the average channel bed immediately upstream from the pier.
Information from bridge plans indicates that the main channel piers of both bridges of structure A5585 are founded on shafts drilled $11 \mathrm{ft}$ into bedrock (figs. 99, 100; table 9). Depth of bed material between bedrock and the bottom of the various scour holes at dual bridge structure A5585 ranged from 29 to $70 \mathrm{ft}$ because of the sloping bedrock in the area (figs. 99, 100; table 9). The minimum channel-bed elevation in each of the scour holes was substantially higher than the bottom of the seal course elevation at each pier of $371.62 \mathrm{ft}$ (figs. 99, 100; table 9).

The difference between the survey on August 1, 2011, and the previous survey on October 21, 2010 (fig. 101) indicates widespread areas of scour and deposition throughout the reach from 2010 to 2011, with an average difference of $-0.53 \mathrm{ft}$ between the bathymetric surfaces (table 7 ). There was substantial deposition on the inside of the river bend on the right (south) bank, whereas there was substantial scour in the thalweg, particularly downstream from the bridges (fig. 101). Overall, there was minimal net change between the surveys as indicated by the mean difference being near zero despite the water-surface elevation difference of more than $11 \mathrm{ft}$ and a flow difference of more than 132,000 ft $3 / \mathrm{s}$ (table 7). The scour holes near pier 5 were deeper on the right (south) side of the piers in the later survey (fig. 101), whereas the scour holes near pier 6 were shallower (fig. 101). The scour hole near pier 7 was substantially deeper at the upstream end-likely because of the debris raft- - but there was deposition from the middle of the upstream pier and downstream (fig. 101). The cross sections from the 2011 survey show the pattern of scour in the thalweg and deposition on the right (south) side of the channel compared to the 2010 survey (figs. 99, 100).

The vertically averaged velocity vectors indicate substantial turbulence throughout the reach, with velocities ranging from about 3 to $10 \mathrm{ft} / \mathrm{s}$ (fig. 102). Flow was angled to the left (north) in the upstream reach because of the bend in the river, and there were numerous local velocity minima on the right (south) side of the channel (fig. 102). Substantial turbulence was observed in the channel thalweg (fig. 102). Piers 5 through 7 were aligned with flow, resulting in minimal turbulence downstream (fig. 102).

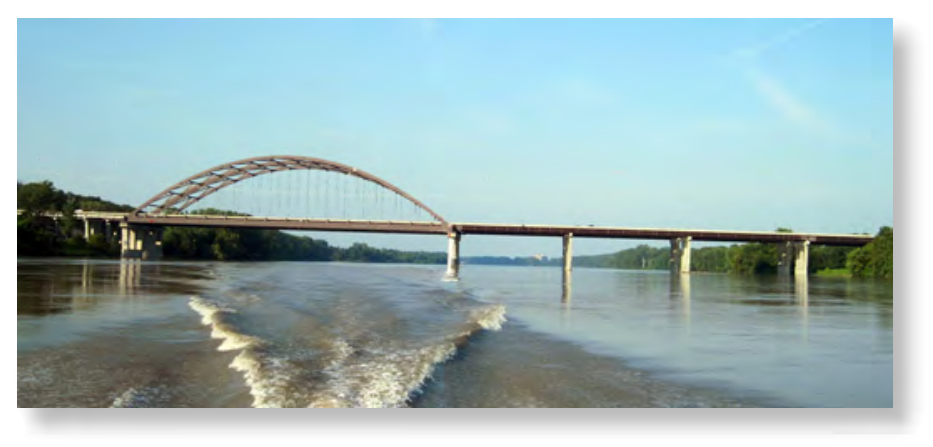

Dual bridge structure A5585 on State Highway 364 near St. Louis, Missouri. 


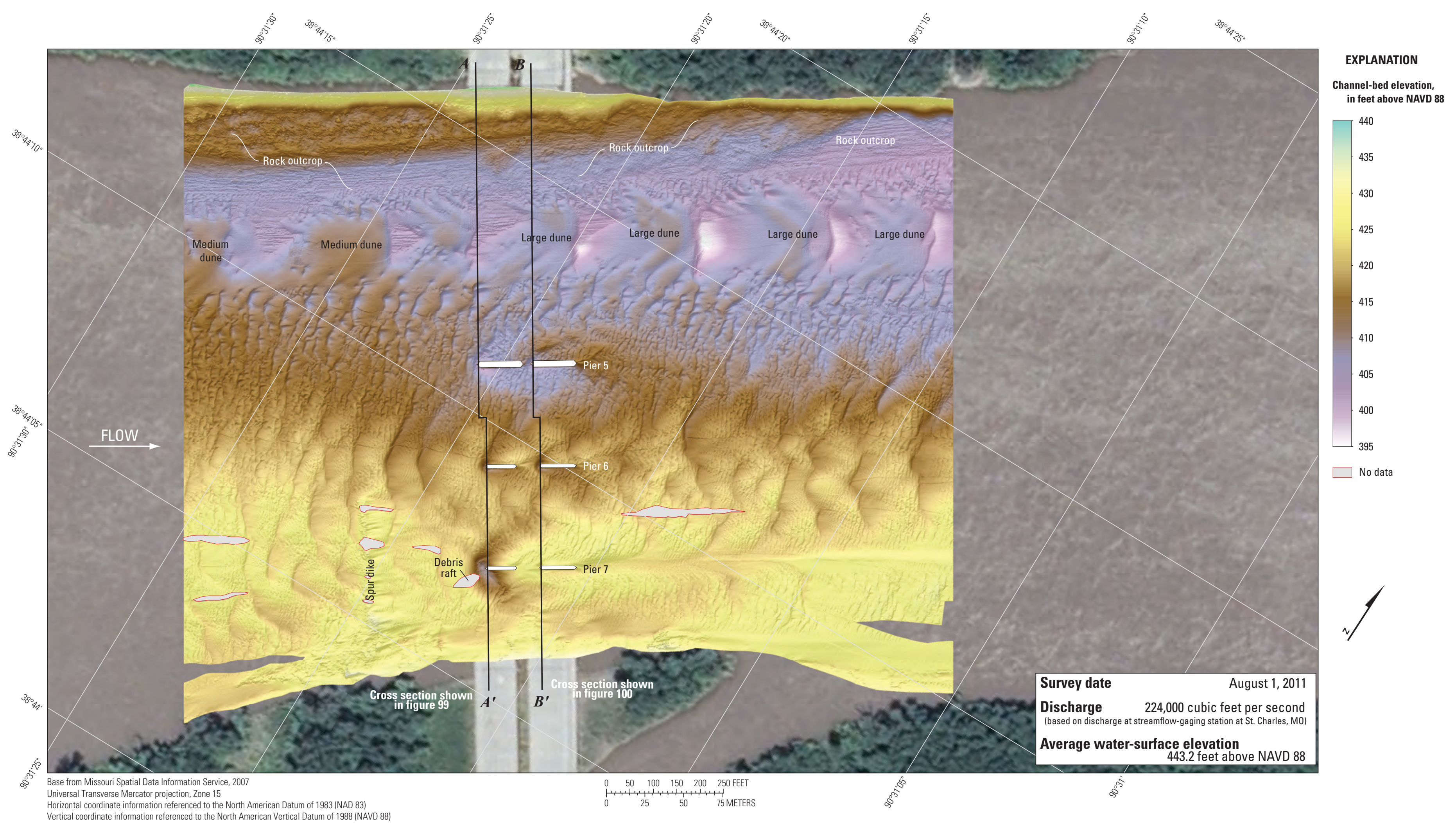

Figure 98. Bathymetric survey of the Missouri River channel in the vicinity of dual bridge structure A5585 on State Highway 364 near St. Louis, Missouri. 


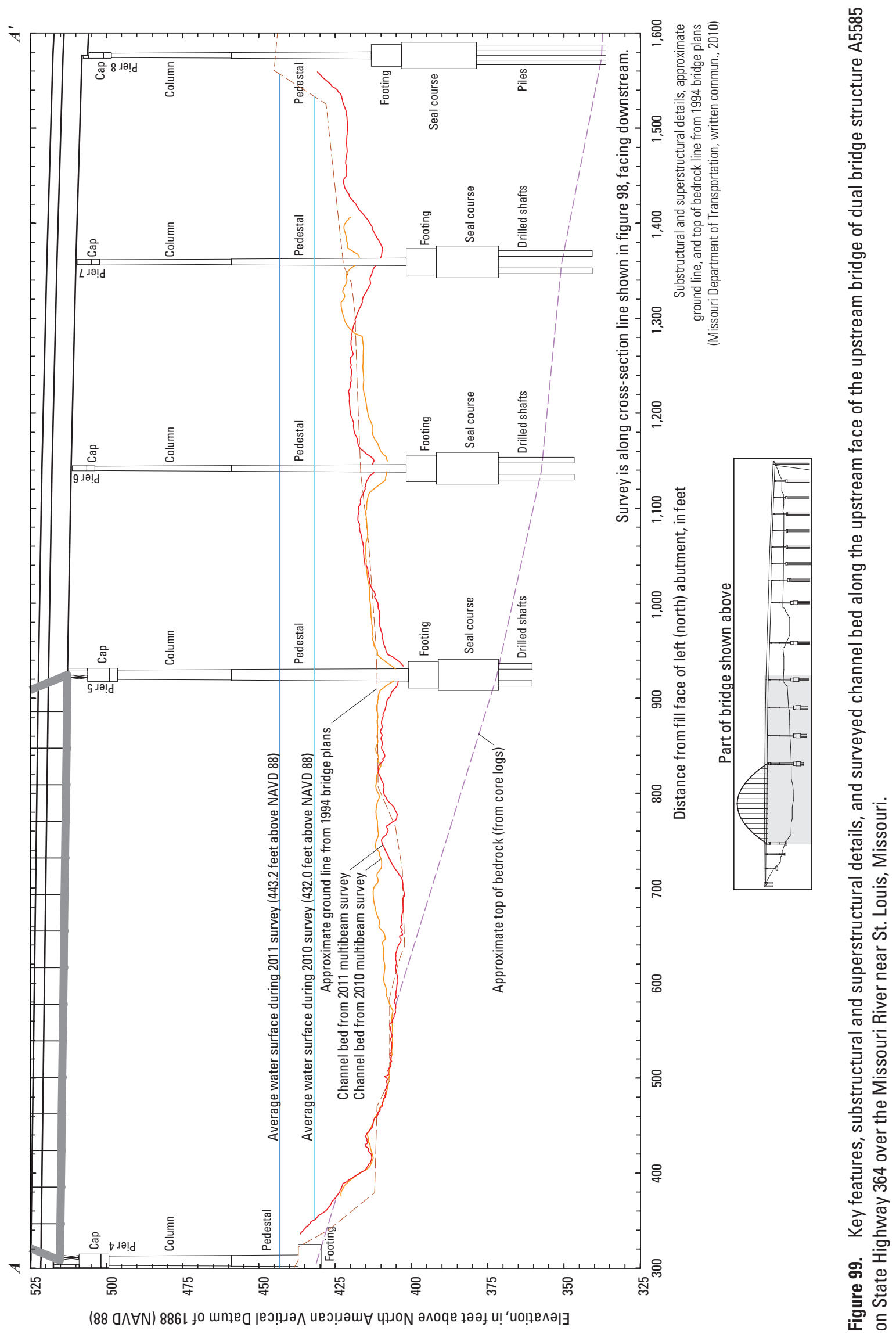




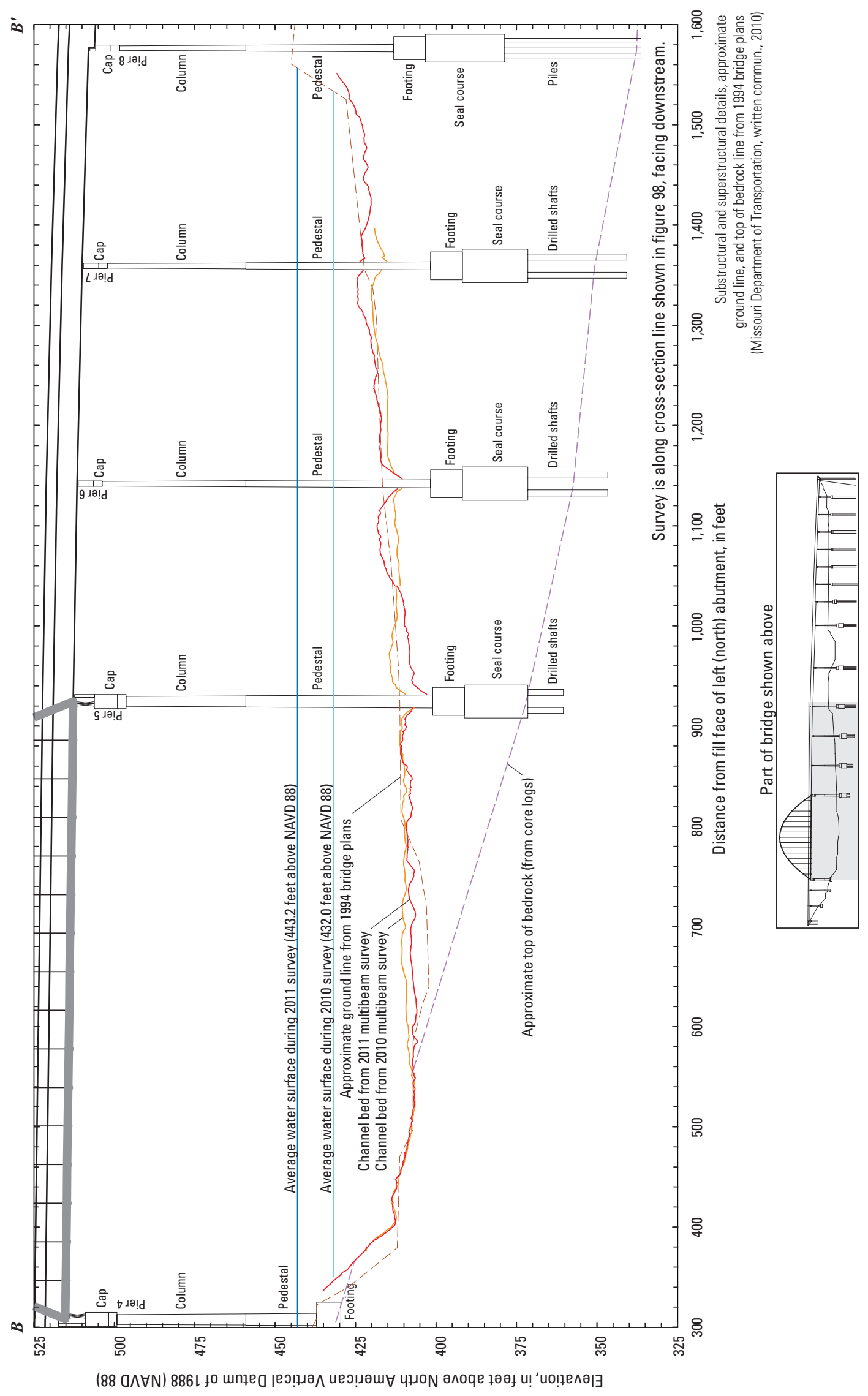

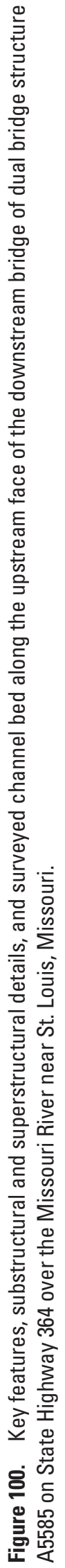




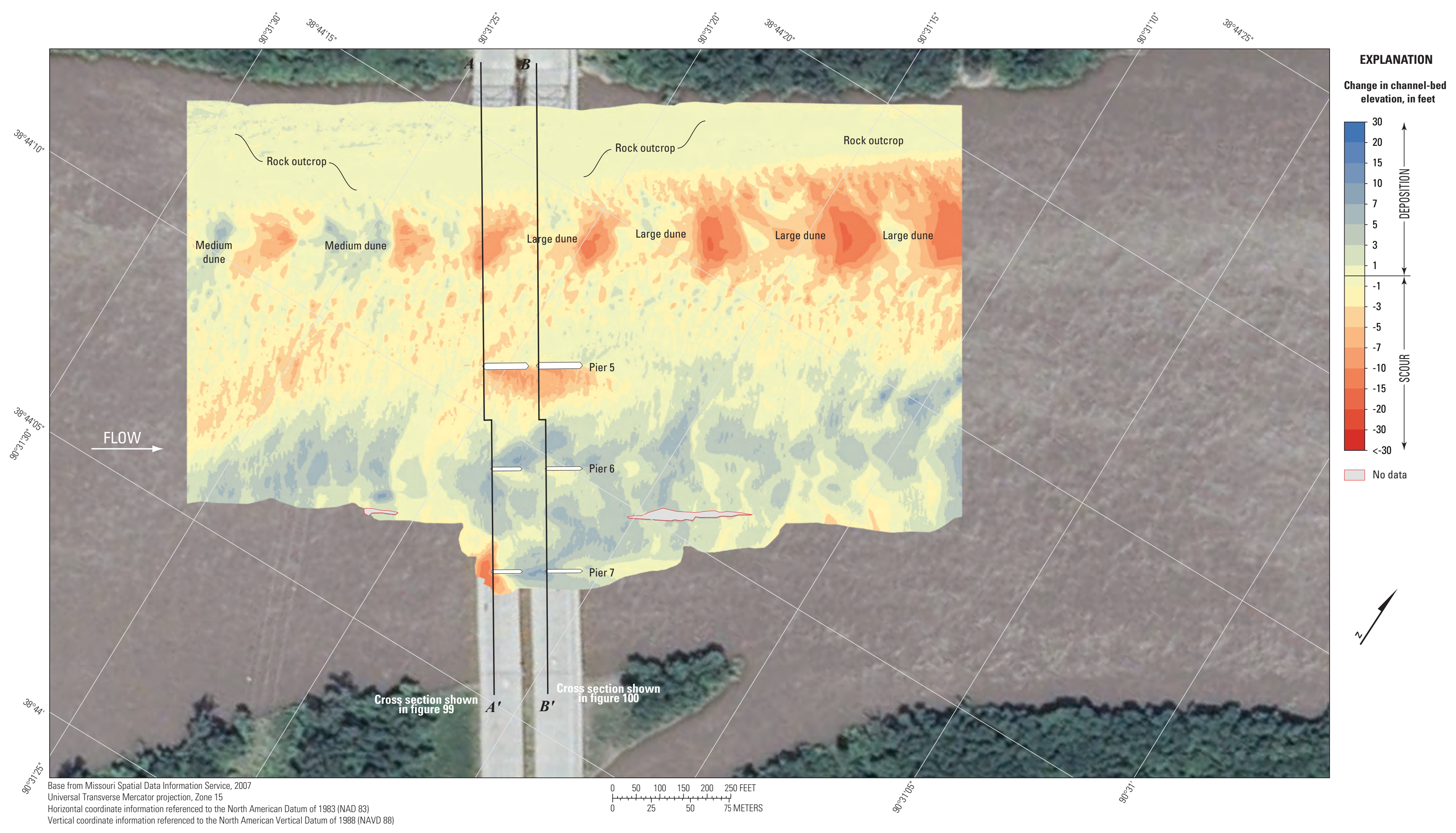

Figure 101. Difference between surfaces created from bathymetric surveys of the Missouri River channel in the vicinity of dual bridge structure A5585 on State Highway 364 near St. Louis, Missouri, on 0ctober 21, 2010 , and August 1, 2011. 


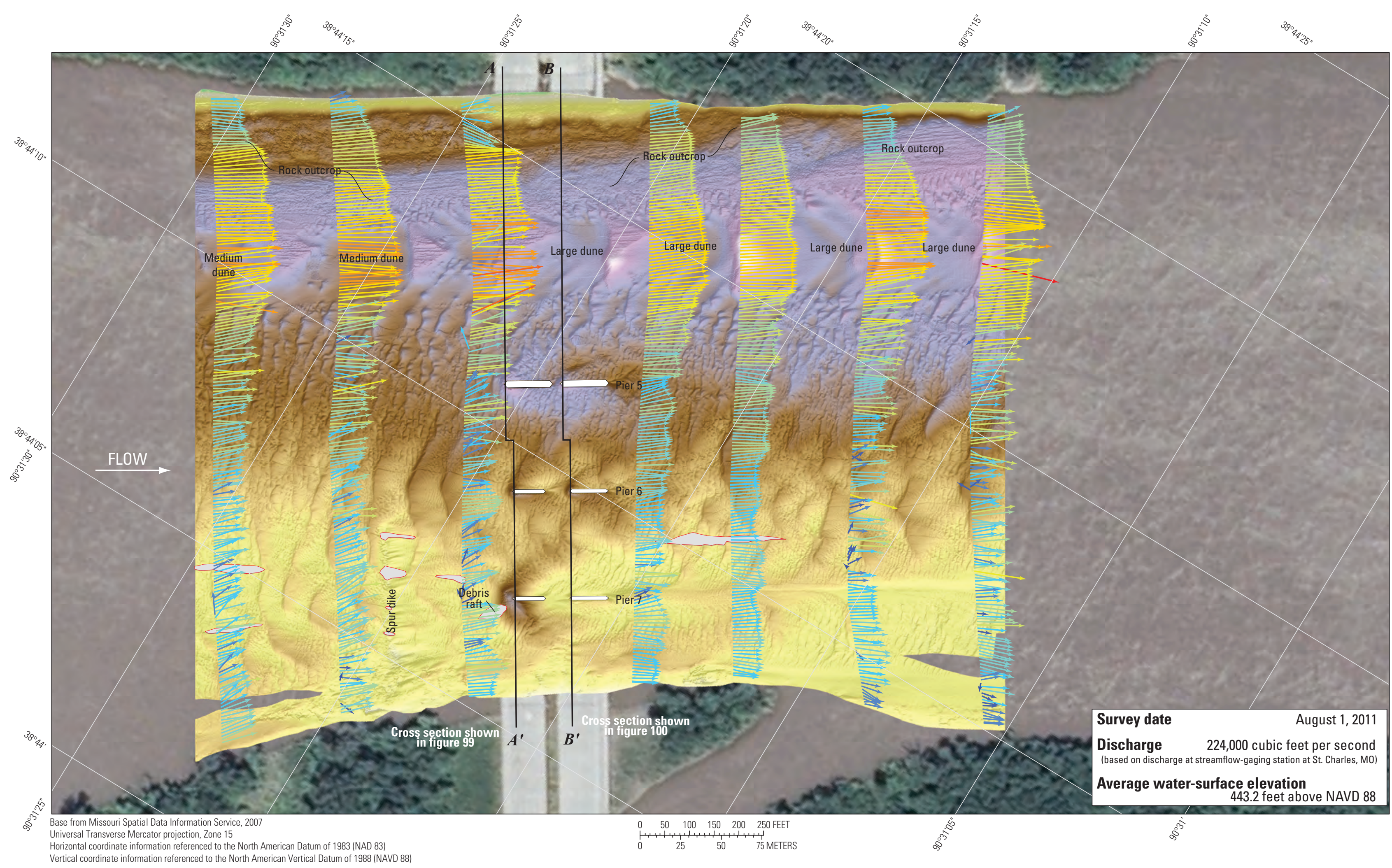

EXPLANATION

Channel-bed elevation,

440

435

430

425

410

405

400

395

$\square$ No data

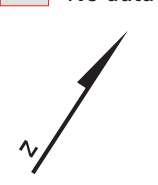

Vertically averaged velocity.

in feet per second

$\stackrel{0-1 \rightarrow}{1-2 \longrightarrow}$

$2-3 \longrightarrow$

$3-4 \longrightarrow$

${ }_{6-7}^{5-6}$

$7-8 \longrightarrow$
$9-10 \longrightarrow$

10-11

Horizontal coordinate information referenced to the North American Datum of 1983 (NAD 83 )
Vertical coordinate information referenced to the North American Vertical Datum of 1988 ( NAVD 8 )

Figure 102. Bathymetry and vertically averaged velocities of the Missouri River channel in the vicinity of dual bridge structure A5585 on State Highway 364 near St. Louis, Missouri. 


\section{Structures A3292 and L0561 on Interstate 70 near St. Louis, Missouri}

Structures A3292 and L0561 (site 25) are dual bridges on Interstate 70 crossing the Missouri River at RM 29.6, in the northwest-central part of the greater St. Louis area (fig. 1). The site was surveyed on August 2, 2011, and the average watersurface elevation of the river in the survey area, determined by the RTK GPS tide solution, was $440.4 \mathrm{ft}$ (table 5). Flow on the Missouri River was about 225,000 $\mathrm{ft}^{3} / \mathrm{s}$ during the survey, according to the streamgage at St. Charles, Missouri (table 5).

The survey area was about 1,640 ft long, and varied in width from about $1,470 \mathrm{ft}$ wide at the upstream end to about $1,000 \mathrm{ft}$ wide at the downstream end, extending from bank to bank in the main channel (fig. 103). The upstream end of the survey area was about $690 \mathrm{ft}$ upstream from the centerline between structures A3292 and L0561 (fig. 103). The channelbed elevations ranged from about 401 to $424 \mathrm{ft}$ for most of the surveyed area ( 5 to 95 percentile range of the bathymetric data), except downstream from the spur dike on the left (north) bank downstream from the bridge, near the piers, and in the downstream channel thalweg (fig.103). The thalweg was on the right (south) bank throughout the reach, and was about 10 to $15 \mathrm{ft}$ deeper than the channel bed in the middle of the channel (fig. 103). The channel and thalweg deepened downstream from the bridges (fig. 103), likely because of the contraction of the channel caused by the building on the left bank downstream from the bridges. On the upstream left (north) side, deposits reached an elevation of about $425 \mathrm{ft}$ (fig. 103). A series of medium to large dune features were observed in the middle of the channel, and numerous medium and small dunes and ripples were detected throughout the rest of the channel (fig. 103). A localized deep scour hole at the end of the shallow spur dike between the downstream bridge and the building on the left bank had a minimum channel-bed elevation of about $396 \mathrm{ft}$ (fig. 103). Stone revetment was observed on the right (south) bank throughout the reach (fig. 103).

A substantial debris raft at the nose of pier 15 of upstream structure A3292 affected the scour near the left main channel piers (pier 15 of upstream structure A3292 and pier 16 of downstream structure L0561; fig. 103). The scour hole caused by the debris raft and piers had a minimum measured elevation of approximately $393 \mathrm{ft}$ near the upstream nose of pier 15 of upstream structure A3292 (fig. 103), about $22 \mathrm{ft}$ below the average channel bed immediately upstream from the raft, but well above the bottom of the seal course elevation of pier 15 of $378.00 \mathrm{ft}$ (fig. 104; table 9). Information from bridge plans indicates that pier 15 of upstream structure A3292 is founded on shafts drilled approximately $16 \mathrm{ft}$ in bedrock (table 9), with about $43 \mathrm{ft}$ of bed material between the bottom of the scour hole and bedrock near the upstream pier (fig. 104). Pier 16 of downstream structure L0561 is founded on a caisson on bedrock (fig. 105; table 9), and the bottom of the local scour hole near this pier was about $57 \mathrm{ft}$ above the bottom of the caisson and bedrock. It is likely that the shallow spur dike between the downstream bridge and the building on the left bank limits the scour that can occur near the downstream pier.

Scour holes also were present in the vicinity of the right main channel piers of structures A3292 and L0561 (fig. 103). The scour hole at upstream pier 16 had a minimum channelbed elevation of about $394 \mathrm{ft}$ (fig. 104; table 9), about $17 \mathrm{ft}$ below the average channel bed immediately upstream from the pier, whereas the scour hole at downstream pier 17 had a minimum channel-bed elevation of about $388 \mathrm{ft}$ (fig. 105; table 9), about $18 \mathrm{ft}$ below the average channel bed immediately upstream from the pier. Information from bridge plans indicates that pier 16 of upstream structure A3292 is founded on shafts drilled $17 \mathrm{ft}$ into bedrock, with about $52 \mathrm{ft}$ of bed material between the bottom of the scour hole and bedrock (fig. 104; table 9). Pier 17 of structure L0561 is founded on a caisson on bedrock, with about $45 \mathrm{ft}$ of bed material between the bottom of the scour hole and bedrock (fig. 105; table 9).

The difference between the survey on August 2, 2011, and the previous survey on October 21, 2010 (fig. 106) indicates a predominance of scour throughout the reach from 2010 to 2011, with an average difference of $-1.72 \mathrm{ft}$ between the bathymetric surfaces (table 7). There was moderate deposition on the inside of the river bend on the upstream left (north) bank, whereas there was substantial scour in the thalweg in the upstream reach, and throughout the channel in the reach at and downstream from the bridges (fig. 106), likely caused by the water-surface elevation difference of more than $10 \mathrm{ft}$ and flow difference of more than 133,000 $\mathrm{ft}^{3} / \mathrm{s}$ (table 7). The scour holes near pier 15 of upstream structure A3292, and both right main channel piers were wider and deeper in the 2011 survey (figs. 104, 105, 106), whereas there was deposition around pier 16 of downstream structure L0561 (figs. 105, 106). The cross sections from the 2011 survey show the pattern of scour in the thalweg and deposition on the left (north) side of the channel compared to the 2010 survey (figs. 104, 105). The stone revetment on the upstream right (south) bank appears to have experienced scour (fig. 106), but this may be a function of positional variations between the surveys. Huizinga (2011) noted issues with horizontal positioning at this site during the survey in October 2010. As with several difference maps earlier in this report, the appearance of substantial deposition or scour at the faces of the piers result from minor horizontal positional variances between the surveys.

The vertically averaged velocity vectors indicate moderate to substantial turbulence in several transects, with velocities ranging from about 3 to $9 \mathrm{ft} / \mathrm{s}$ (fig. 107). Flow was angled to the right (south) in the upstream reach because of the bend in the river and the downstream contraction, and there was substantial turbulence and flow reversal near the contraction (fig. 107). Flow was mostly uniform in the reach downstream from the bridges, with minor turbulence in the channel thalweg of the downstream-most transect (fig. 107). The right main channel piers were aligned with flow, whereas the left main channel piers were not; moderate turbulence was observed downstream from all piers (fig. 107). 


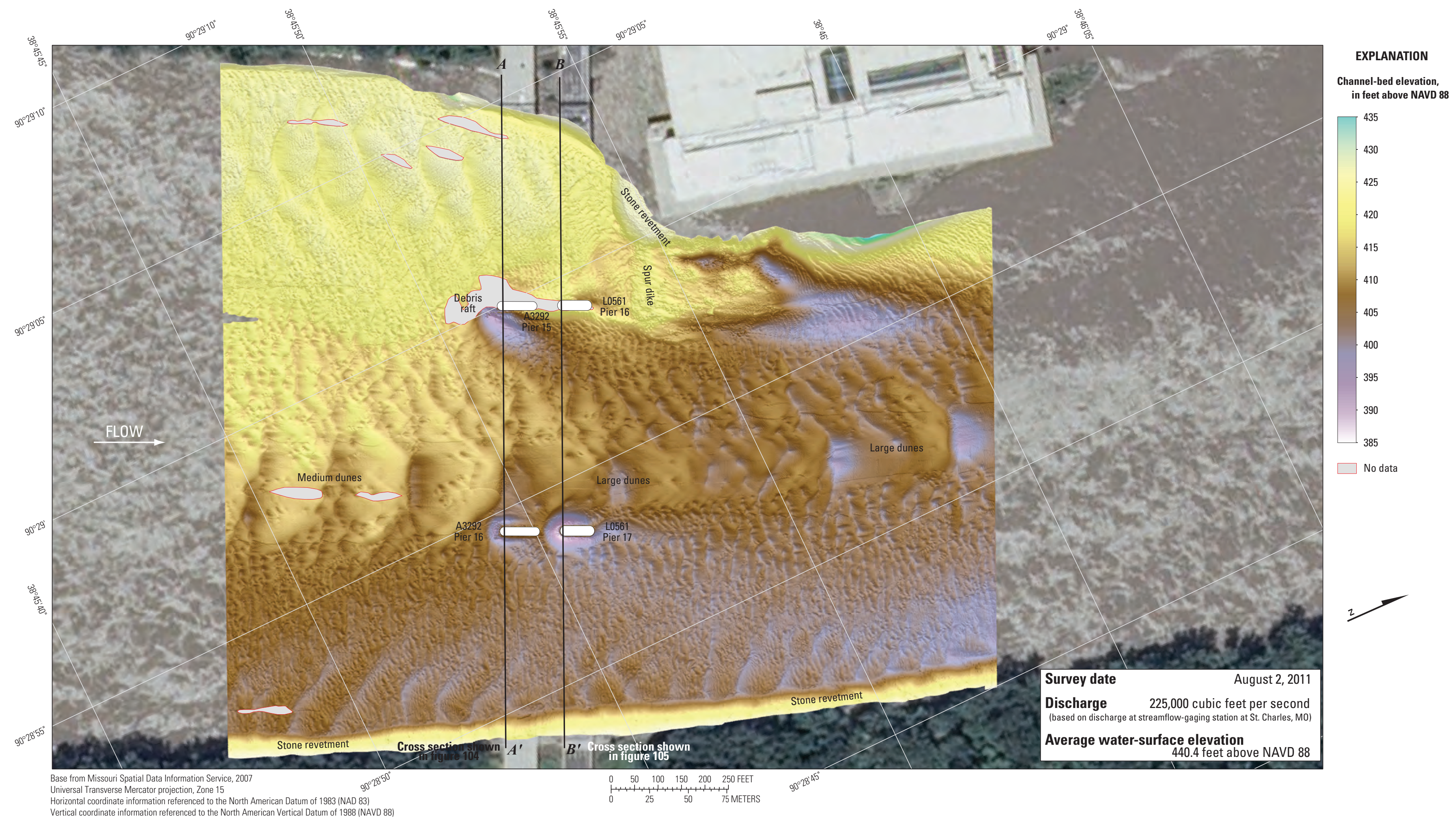

Figure 103. Bathymetric survey of the Missouri River channel in the vicinity of structures A3292 and L0561 on Interstate 70 near St. Louis, Missouri. 


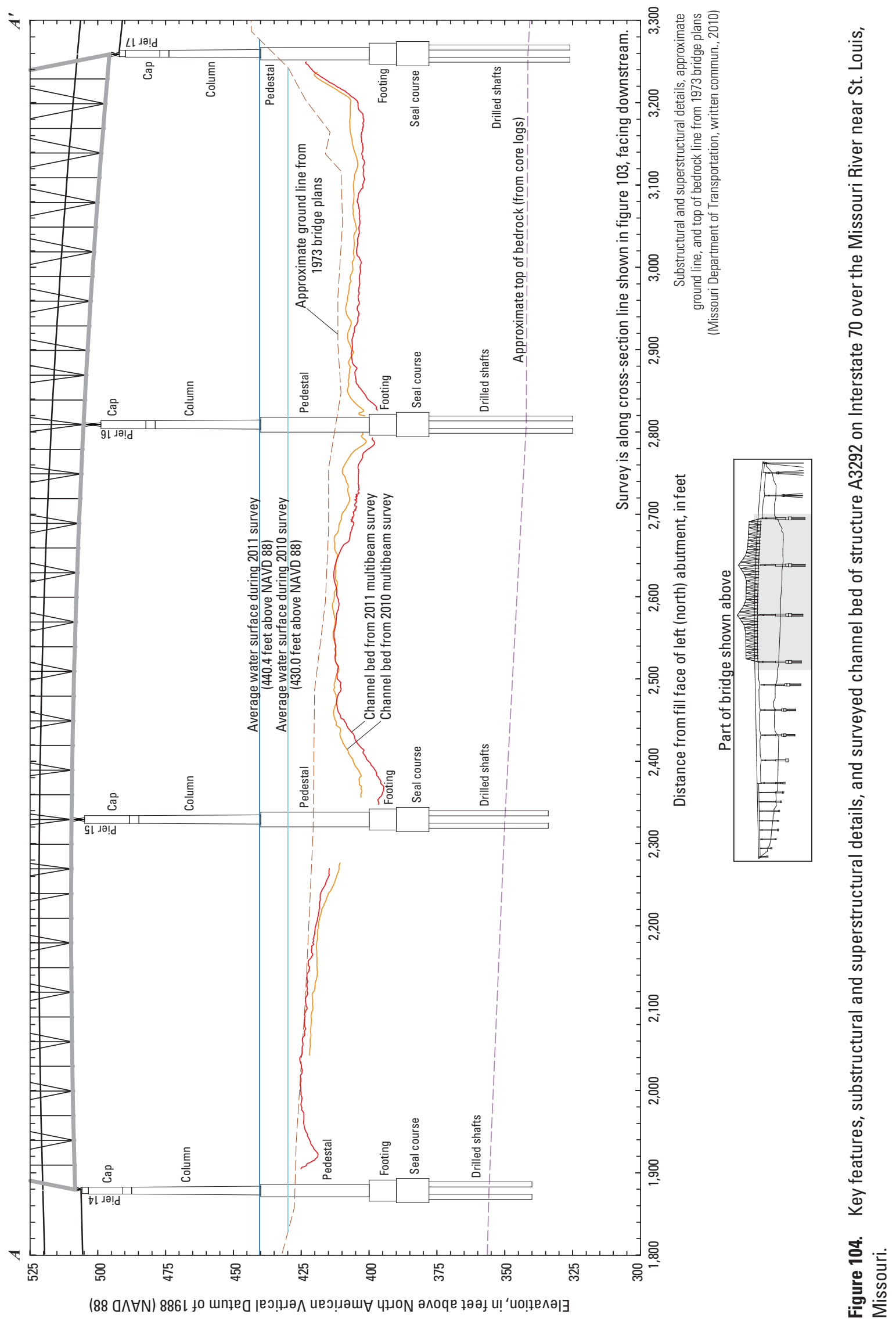




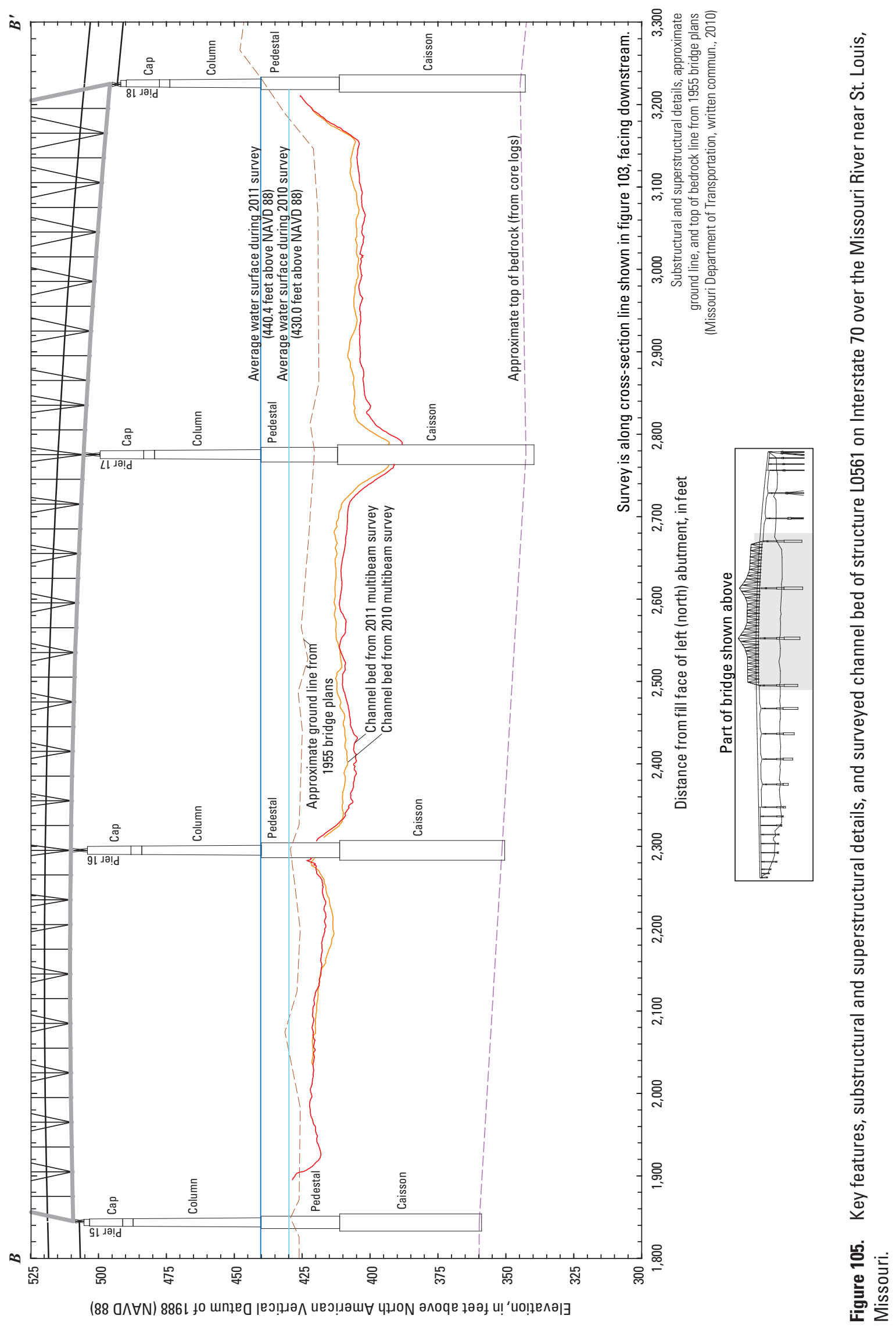




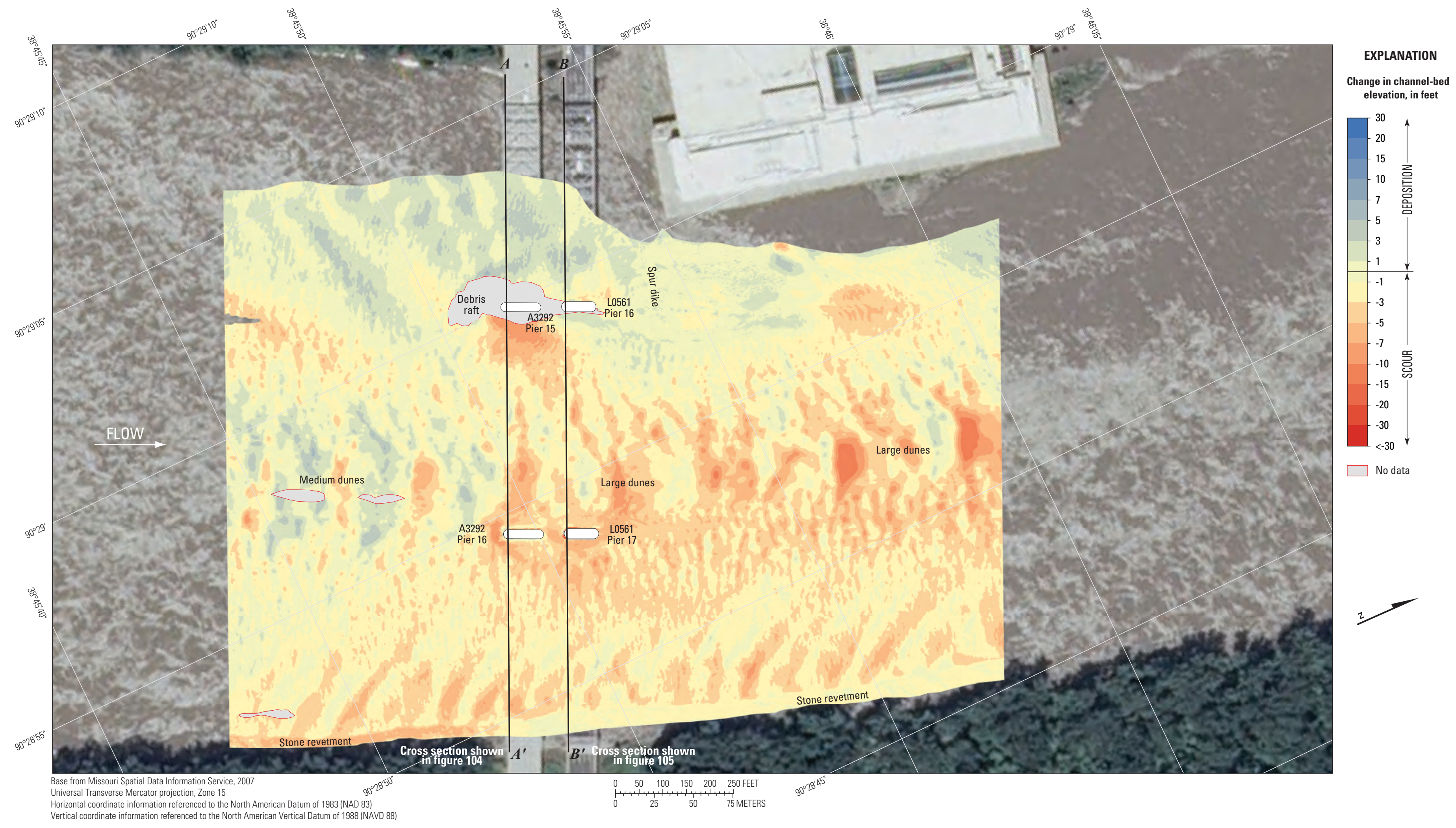

Figure 106. Difference between surfaces created from bathymetric surveys of the Missouri River channel in the vicinity of structures A3292 and L0561 on Interstate 70 near St. Louis, Missouri, on 0ctober 21, 2010, and August 2, 2011. 


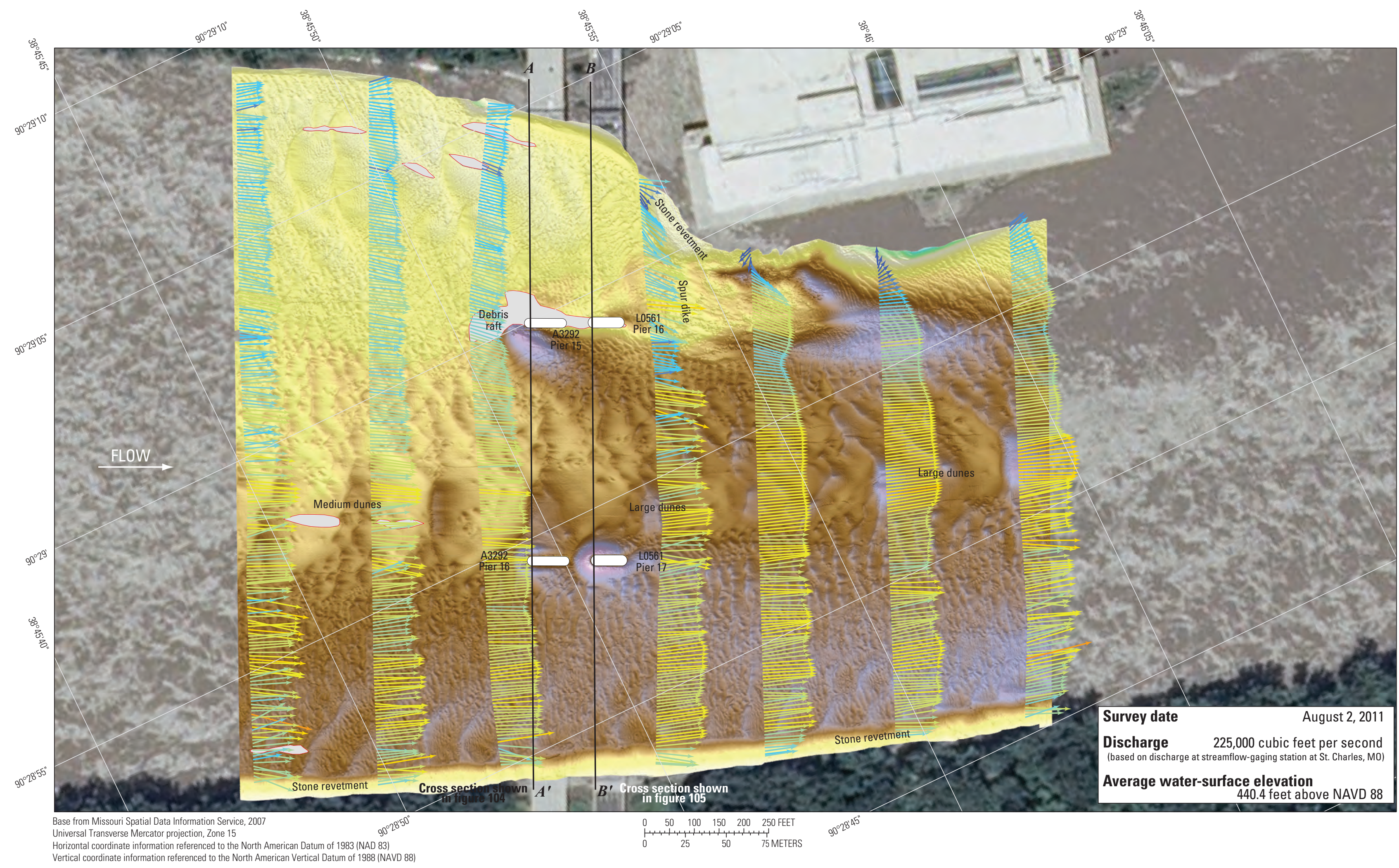

EXPLANATION

Channel-bed elevation,
in feet above NAVD 88

$\square 35$

425

420

415

410

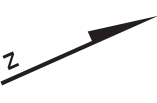

$\operatorname{lin}_{2.3}$

(a)

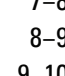

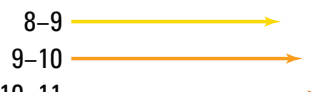




\section{Dual Bridge Structure A4557 on State Highway 370 near St. Louis, Missouri}

Structure A4557 (site 26) consists of twin bridges on State Highway 370 crossing the Missouri River at RM 27.0, in the north-central part of the greater St. Louis area (fig. 1). The site was surveyed on August 2, 2011, and the average water-surface elevation of the river in the survey area, determined by the RTK GPS tide solution, was $438.2 \mathrm{ft}$ (table 5). Flow on the Missouri River was about $225,000 \mathrm{ft}^{3} / \mathrm{s}$ during the survey, according to the streamgage at St. Charles, Missouri (table 5).

The survey area was about 1,640 ft long and averaged about 1,210 ft wide, extending from bank to bank in the main channel (fig. 108). The upstream end of the survey area was about $670 \mathrm{ft}$ upstream from the centerline of structure A4557 (fig. 108). The channel-bed elevations ranged from about 399 to $417 \mathrm{ft}$ for most of the surveyed area ( 5 to 95 percentile range of the bathymetric data), except near the piers and along the toe of the rock outcrop along the left (north) side of the channel, which had a minimum channel-bed elevation of approximately $392 \mathrm{ft}$ (fig. 108; table 5). A series of medium dune features were observed in the channel thalweg, and numerous small dunes and ripples were detected throughout the rest of the channel (fig. 108). A spur dike was present under the downstream bridge on the right (south) bank (fig. 108).

Small scour holes were present in the vicinity of the main channel piers, except those near the spur dike on the right side of the channel (pier 4C at both bridges; fig. 108). At pier $2 \mathrm{C}$, the scour hole at the upstream pier had a minimum channel-bed elevation of about $404 \mathrm{ft}$ (fig. 108; table 9), about $4 \mathrm{ft}$ below the average channel bed immediately upstream from the pier, and the scour hole at the downstream pier had a minimum channel-bed elevation of about $403 \mathrm{ft}$ (fig. 108; table 9), about $6 \mathrm{ft}$ below the average channel bed immediately upstream from the pier. At pier $3 \mathrm{C}$, the scour hole at the upstream pier had a minimum channel-bed elevation of about $403 \mathrm{ft}$ (fig. 108; table 9), about $5 \mathrm{ft}$ below the average channel bed immediately upstream from the pier, whereas the scour hole at the downstream pier had a minimum channel-bed elevation of about $402 \mathrm{ft}$ (fig. 108; table 9), about $6 \mathrm{ft}$ below the average channel bed immediately upstream from the pier. There essentially was no scour hole around either upstream or downstream pier 4C (fig. 108); however, the spur dike adjacent to these piers caused a local deep hole that reached a minimum channel-bed elevation of about $403 \mathrm{ft}$ (fig. 108; table 9). These piers essentially were embedded in the rock of the dike, which will limit or prevent additional scour near both of them. Material from the toe of the spur dike extended to downstream pier 3C, and may limit scour on the right (south) side of that pier as well.

A substantial scour hole was observed at the railroad bridge pier upstream from pier 2C (fig. 108). The hole had a minimum channel-bed elevation of $390 \mathrm{ft}$ at the nose of the pier, about $20 \mathrm{ft}$ below the average channel bed immediately upstream from the pier (fig. 108). A smaller scour hole also was present at the railroad bridge pier upstream from pier $4 \mathrm{C}$, which had a minimum channel-bed elevation of $402 \mathrm{ft}$ at the nose of the pier, about $5 \mathrm{ft}$ below the average channel bed immediately upstream from the pier (fig. 108). The scour holes at the railroad bridge piers did not appear to affect the scour at piers 2C or 4C of structure A4557 (fig. 108).

Information from bridge plans indicates that the main channel piers of both bridges of structure A4557 are founded on shafts drilled $15 \mathrm{ft}$ into bedrock (figs. 109, 110; table 9). Depth of bed material between bedrock and the bottom of the various scour holes at dual bridge structure A4557 ranged from 45 to $66 \mathrm{ft}$ because of the sloping bedrock and channel bed in the area (figs. 109, 110; table 9). The minimum channel-bed elevation in each of the scour holes was more than $9 \mathrm{ft}$ higher than the bottom of the seal course elevation at each pier (figs. 109, 110; table 9).

The difference between the survey on August 2, 2011, and the previous survey on October 22, 2010 (fig. 111) indicates little substantial change in the reach from 2010 to 2011, with an average difference of only $-0.18 \mathrm{ft}$ between the bathymetric surfaces despite the water-surface elevation difference of nearly $10 \mathrm{ft}$ and flow difference of 135,000 $\mathrm{ft}^{3} / \mathrm{s}$ (table 7). There was moderate scour in the thalweg in the downstream reach, and widespread minor deposition throughout the middle and right (south) side of the channel (fig. 111). The scour holes near piers 2C and 3C were similar to or shallower in the 2011 survey than in 2010, whereas there was no change near pier 4C (figs. 109, 110, 111). The cross sections from the 2011 survey show the similarity of the channel between the 2010 and 2011 surveys, with balanced areas of minor scour and deposition (figs. 109, 110). The scour hole near the railroad bridge pier upstream from pier 2C was slightly deeper in 2011 than in 2010, whereas the hole near the railroad bridge pier upstream from pier 4C was nearly the same or slightly shallower in 2011 than in 2010 (fig. 111).

The vertically averaged velocity vectors indicate moderate to substantial turbulence in several transects, with velocities ranging from about 2 to $10 \mathrm{ft} / \mathrm{s}$ (fig. 112). There was substantial turbulence and flow reversal near the spur dike on the right (south) bank and near the left (north) bank where the rock outcrop had substantial variations (fig. 112). Flow was mostly uniform in the thalweg downstream from the bridges (fig. 112). All the piers were aligned with flow, and there was little to no turbulence observed downstream that can be directly attributed to the piers (fig. 112).

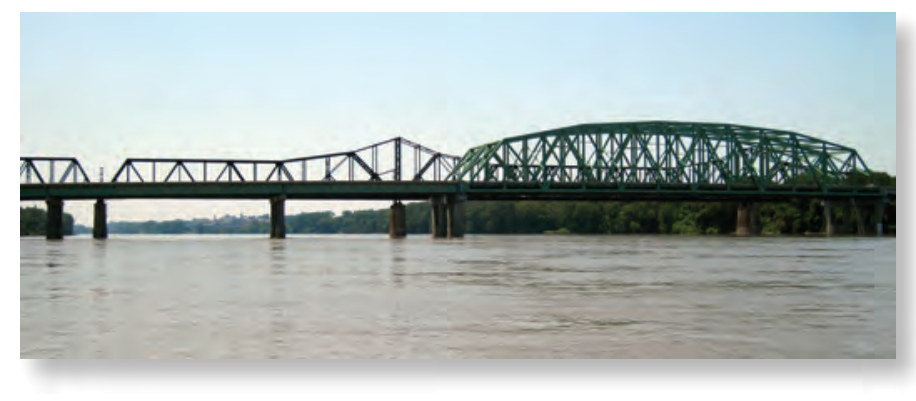

Dual bridge structure A4557 on State Highway 370 near St. Louis, Missouri. The Wabash railroad bridge is in the background. 


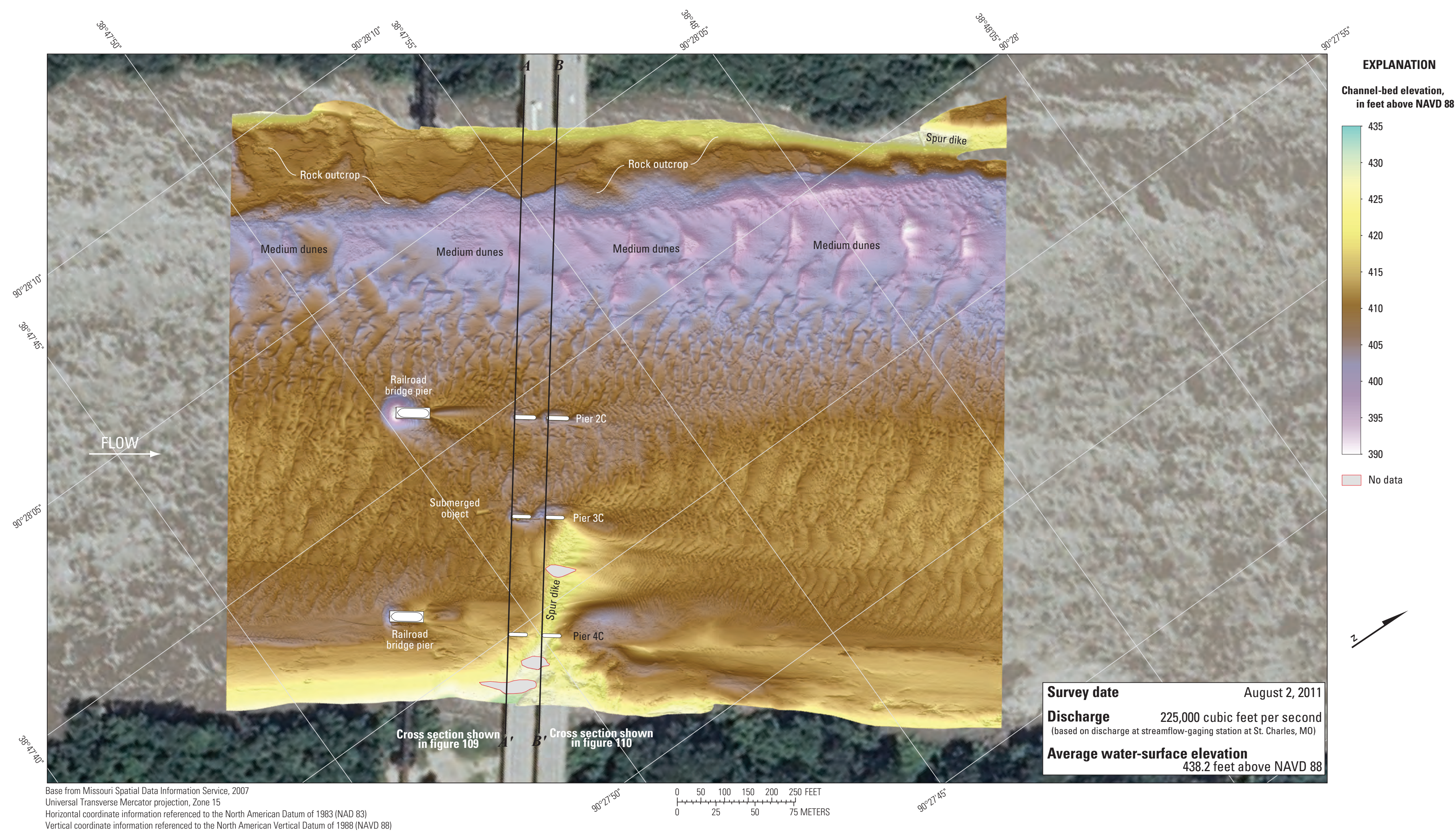

Figure 108. Bathymetric survey of the Missouri River channel in the vicinity of dual bridge structure A4557 on State Highway 370 near St. Louis, Missouri. 


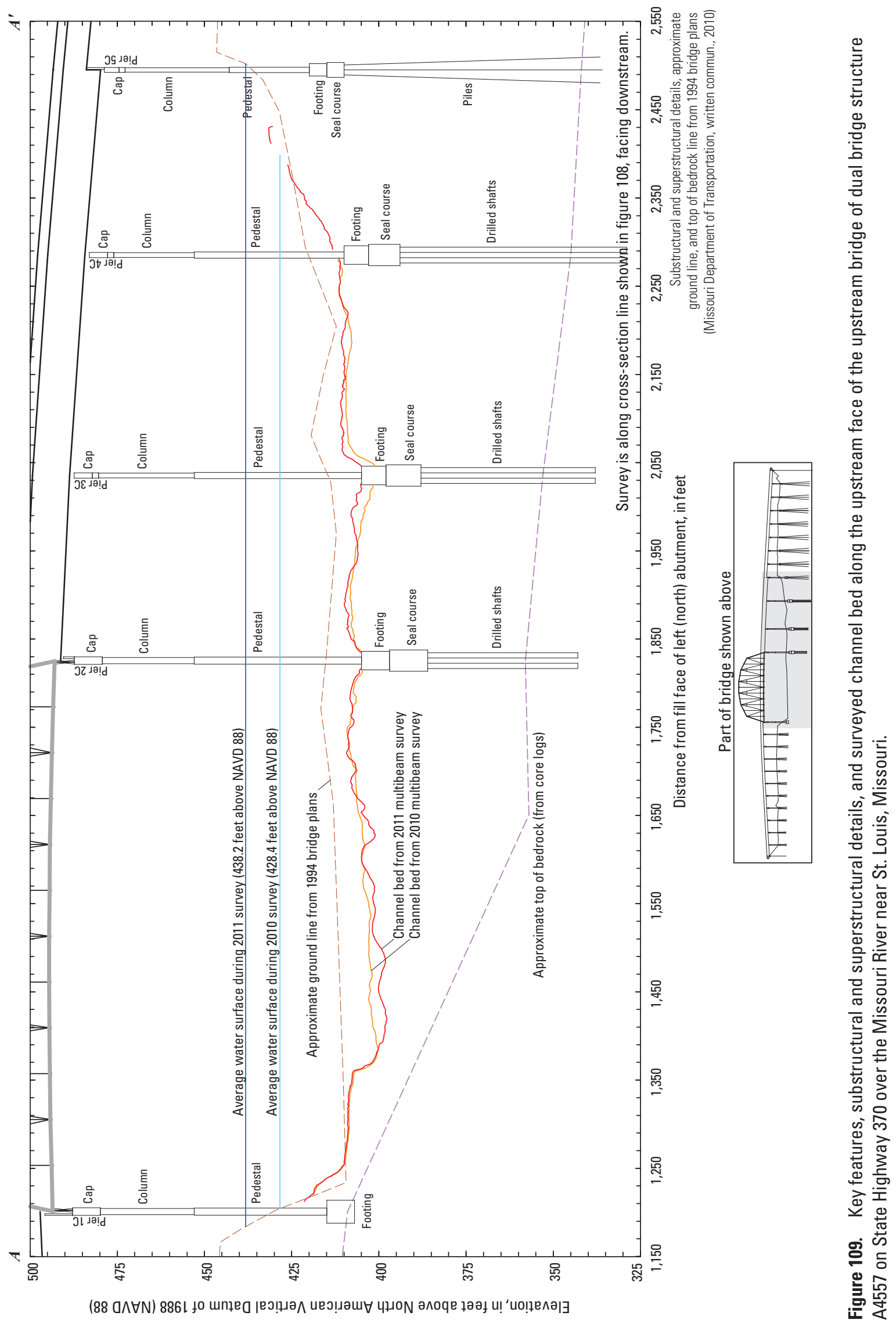




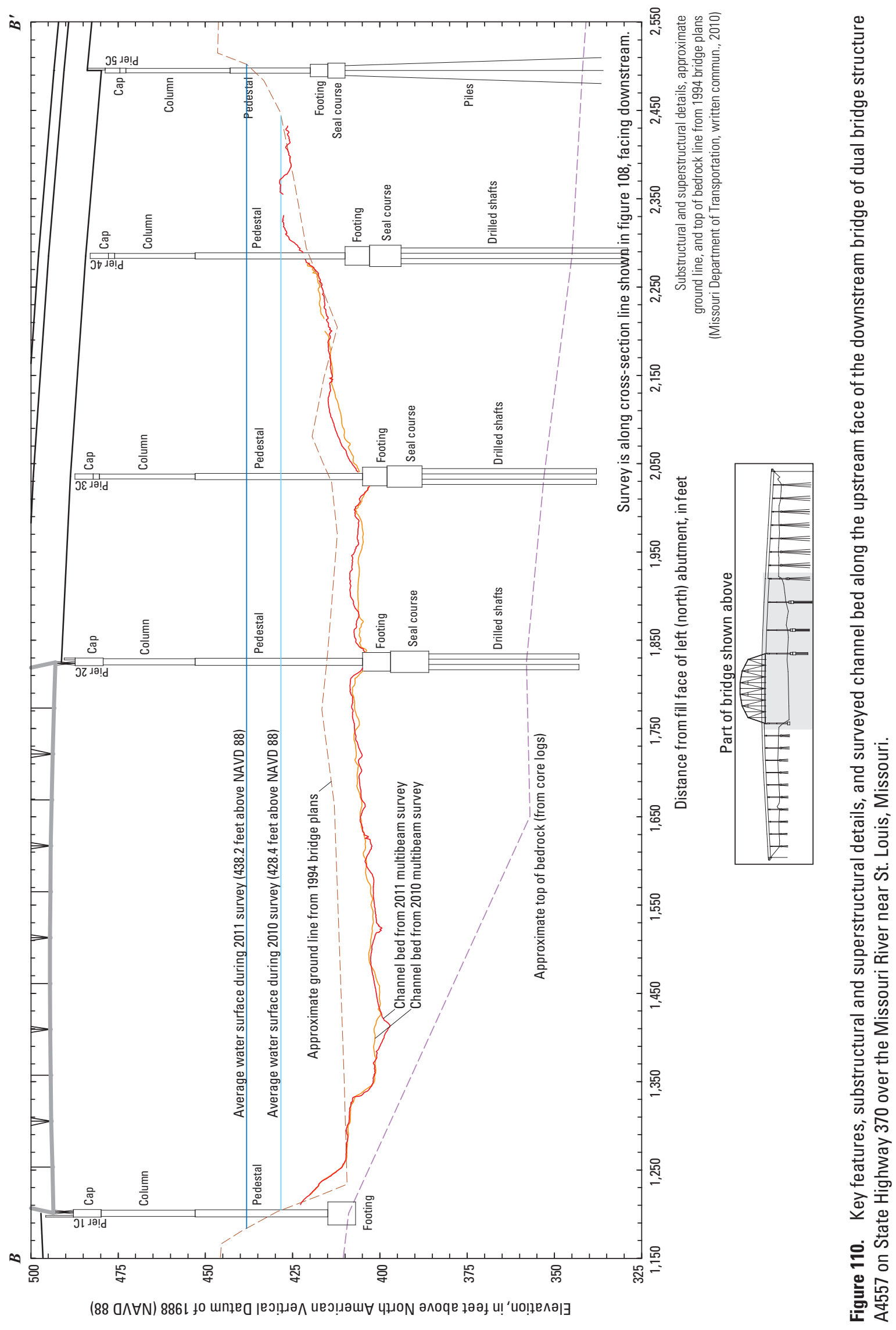




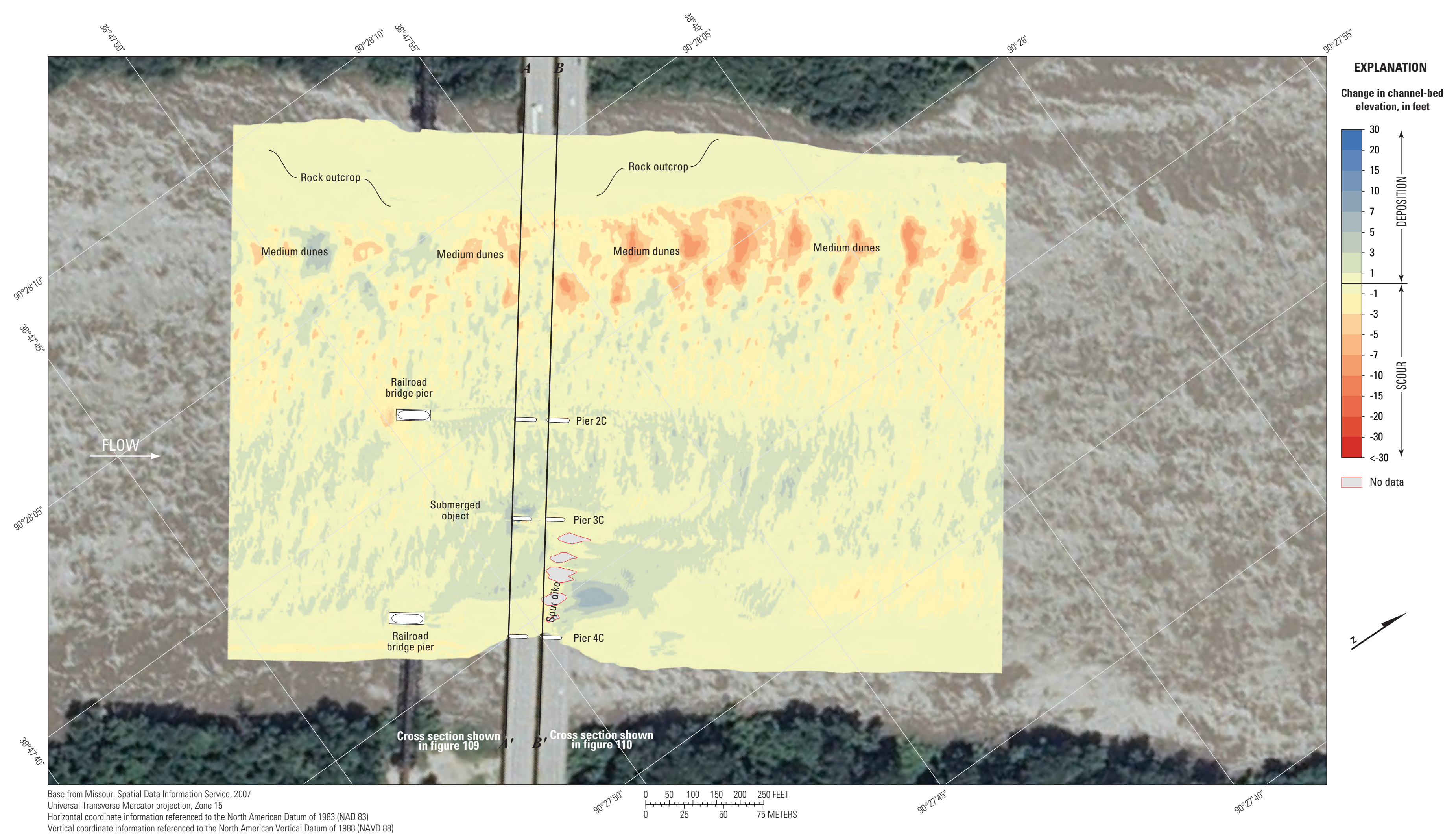

Figure 111. Difference between surfaces created from bathymetric surveys of the Missouri River channel in the vicinity of dual bridge structure A4557 on State Highway 370 near St. Louis, Missouri, on 0ctober 22, 2010 , and August 2, 2011. 


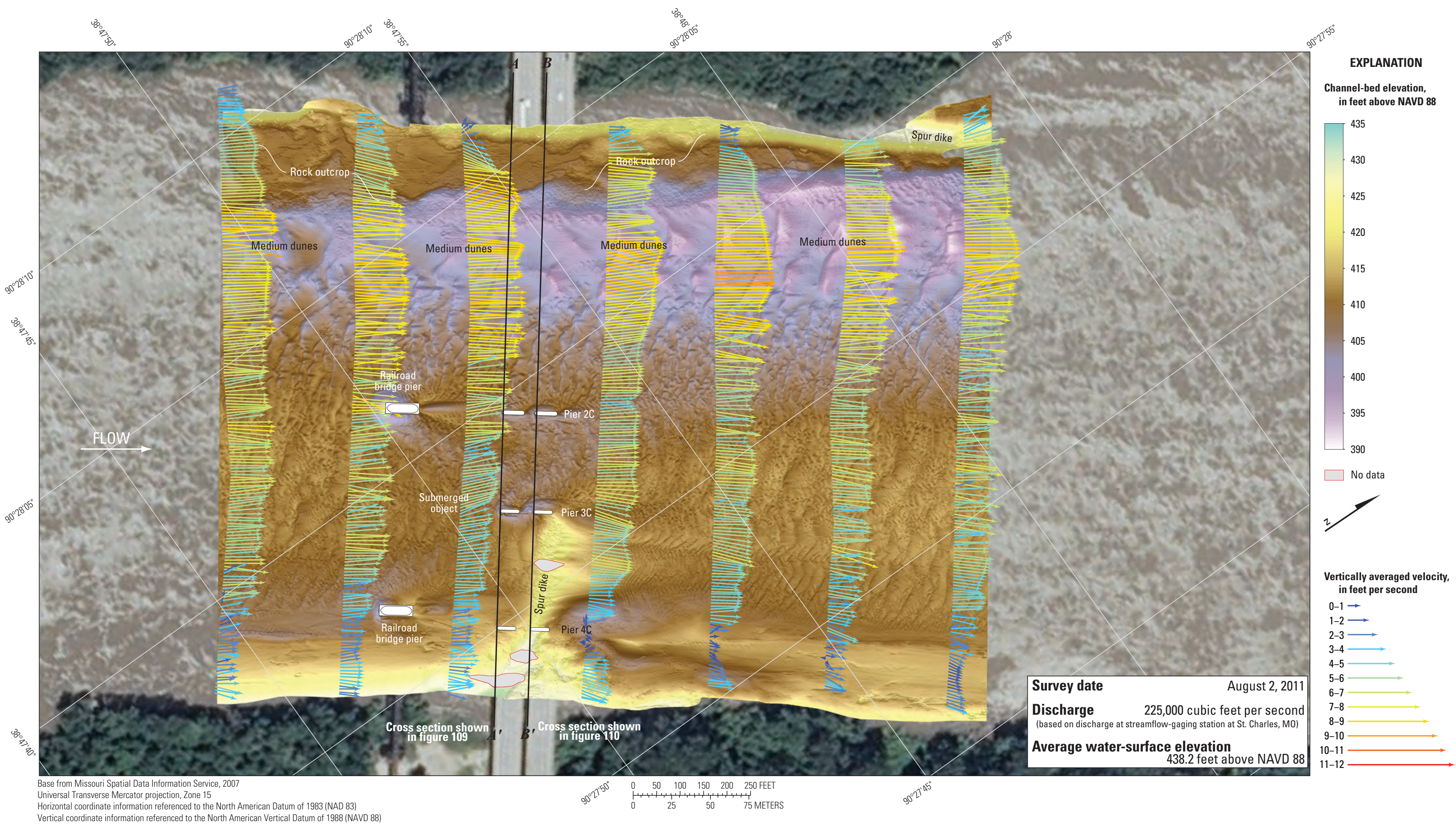

Figure 112. Bathymetry and vertically averaged velocities of the Missouri River channel in the vicinity of dual bridge structure A4557 on State Highway 370 near St. Louis, Missouri 


\section{Structure A3047 on U.S. Highway 67}

Structure A3047 (site 27) on U.S. Highway 67 crosses the Missouri River at RM 8.1, on the northeastern side of the greater St. Louis area (fig. 1). The site was surveyed on August 3,2011 , and the average water-surface elevation of the river in the survey area, determined by the RTK GPS tide solution, was $421.8 \mathrm{ft}$ (table 5). Flow on the Missouri River was about $225,000 \mathrm{ft}^{3} / \mathrm{s}$ during the survey, according to the streamgage at St. Charles, Missouri (table 5).

The survey area was about 1,640 ft long and about $1,360 \mathrm{ft}$ wide, extending essentially from bank to bank in the main channel (fig. 113). The upstream end of the survey area was about $670 \mathrm{ft}$ upstream from the centerline of structure A3047 (fig. 113). The channel-bed elevations ranged from about 381 to $404 \mathrm{ft}$ for most of the surveyed area (5 to 95 percentile range of the bathymetric data) except in the upstream thalweg. A deep thalweg on the left (north) bank was about 10 to $15 \mathrm{ft}$ deeper than the channel bed in the middle of the channel (fig. 113). In the vicinity of the spur dike on the right (south) side near the bridge, deposits reached an elevation of about $402 \mathrm{ft}$, and behind the longitudinal spur dike on the left (north) side near the bridge, deposits reached an elevation of about $408 \mathrm{ft}$ (fig. 113). Numerous small dunes and ripples were detected throughout the channel, and a few medium dune features with superimposed small dunes and ripples were detected in the upstream channel thalweg (fig. 113). Stone revetment was present on the upstream right (south) bank (fig. 113).

Small to moderate scour holes were present in the vicinity of the main channel piers, except pier 10 near the longitudinal spur dike on the left (north) side of the channel (fig. 113). In the immediate vicinity of pier 10, the channel thalweg had a minimum channel-bed elevation of about 380 $\mathrm{ft}$ (fig. 113; table 9), which is about $34 \mathrm{ft}$ above the bottom of the seal course elevation of $346.50 \mathrm{ft}$ (fig. 114; table 9). Pier 10 was essentially embedded in the rock of a longitudinal spur dike, which will limit or prevent scour at this pier. At pier 11, the scour hole had a minimum channel-bed elevation of about $378 \mathrm{ft}$, about $7 \mathrm{ft}$ below the average channel bed immediately upstream from the pier (fig. 113; table 9). At pier 12, the scour hole had a minimum channel-bed elevation of about $390 \mathrm{ft}$, about $6 \mathrm{ft}$ below the average channel bed immediately upstream from the pier (fig. 113; table 9).

Information from bridge plans indicates that pier 10 is founded on shafts drilled $13 \mathrm{ft}$ into bedrock, with about $77 \mathrm{ft}$ of bed material between the channel thalweg and bedrock at the bridge, and about $88 \mathrm{ft}$ of bed material between the bed at the nose of the pier and bedrock (fig. 114; table 9). Pier 11 is founded on shafts drilled $15 \mathrm{ft}$ into bedrock, with about $65 \mathrm{ft}$ of bed material between the bottom of the scour hole and bedrock (fig. 114; table 9). Pier 12 is founded on shafts drilled $26 \mathrm{ft}$ into bedrock, with about $54 \mathrm{ft}$ of bed material between the bottom of the scour hole and bedrock (fig. 114; table 9).
Scour holes also were observed near the railroad bridge piers upstream from structure A3047. The scour hole in the vicinity of the railroad bridge pier upstream from pier 10 was essentially indistinguishable from the channel thalweg (fig. 113); however, substantial scour holes were present in the vicinity of the railroad bridge piers upstream from piers 11 and 12. Scour near the upstream railroad bridge piers did not appear to have an effect on the piers of structure A3047 (fig. 113). The remnant of old bridge piers were observed in the channel downstream from the existing railroad bridge piers (fig. 113).

The difference between the survey on August 3, 2011, and the previous survey on October 25, 2010 (fig. 115) indicates widespread scour throughout the reach from 2010 to 2011, with an average difference of $-2.69 \mathrm{ft}$ between the bathymetric surfaces (table 7). There was a difference in water-surface elevation of nearly $12 \mathrm{ft}$ and a flow difference of nearly $138,000 \mathrm{ft}^{3} / \mathrm{s}$ between the surveys (table 7). There was moderate deposition on the right (south) side of the channel and in the areas behind the longitudinal spur dikes on the left (north) side, but there was moderate to substantial scour in the thalweg (fig. 115). The minimum elevation of the scour holes near piers 11 and 12 were similar to the 2010 survey, whereas the rest of the cross section from the 2011 survey shows the overall scour between the 2010 and 2011 surveys (figs. 114, $115)$. The scour hole near the railroad bridge pier upstream from pier 11 was slightly deeper in 2011 than in 2010, whereas the hole near the railroad bridge pier upstream from pier 12 was nearly the same or slightly shallower in 2011 than in 2010 (fig. 115).

The vertically averaged velocity vectors indicate moderate to substantial turbulence in several transects, with velocities ranging from about 3 to $9 \mathrm{ft} / \mathrm{s}$ (fig. 116). There was substantial turbulence and flow reversal near the longitudinal spur dikes on the left (north) bank, and near the right (south) bank where the stone revetment had substantial variations (fig. 116). Flow was mostly uniform in the transects between the railroad bridge and structure A3047, and in the three downstream-most transects (fig. 116). All the piers were slightly skewed to flow, with minor turbulence observed downstream from the piers (fig. 116).

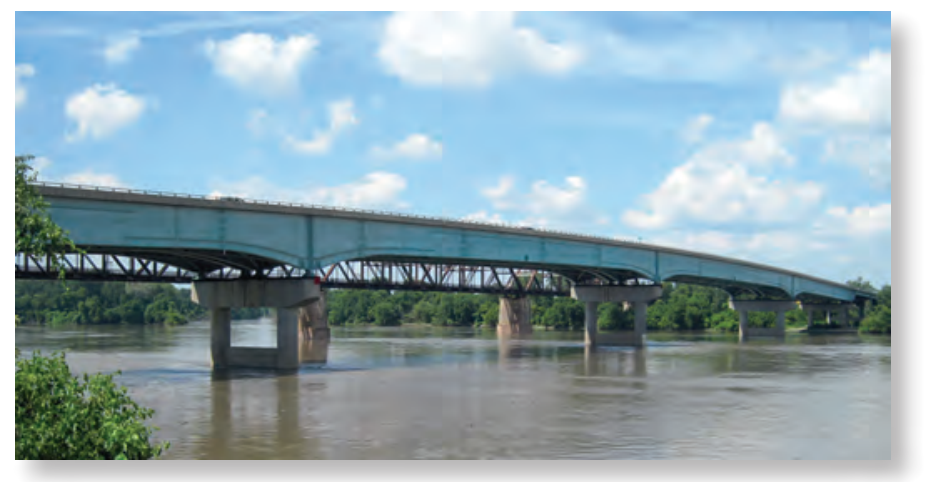

Structure A3047 on U.S. Highway 67 near St. Louis, Missouri. The Bellefontaine railroad bridge is in the background. 


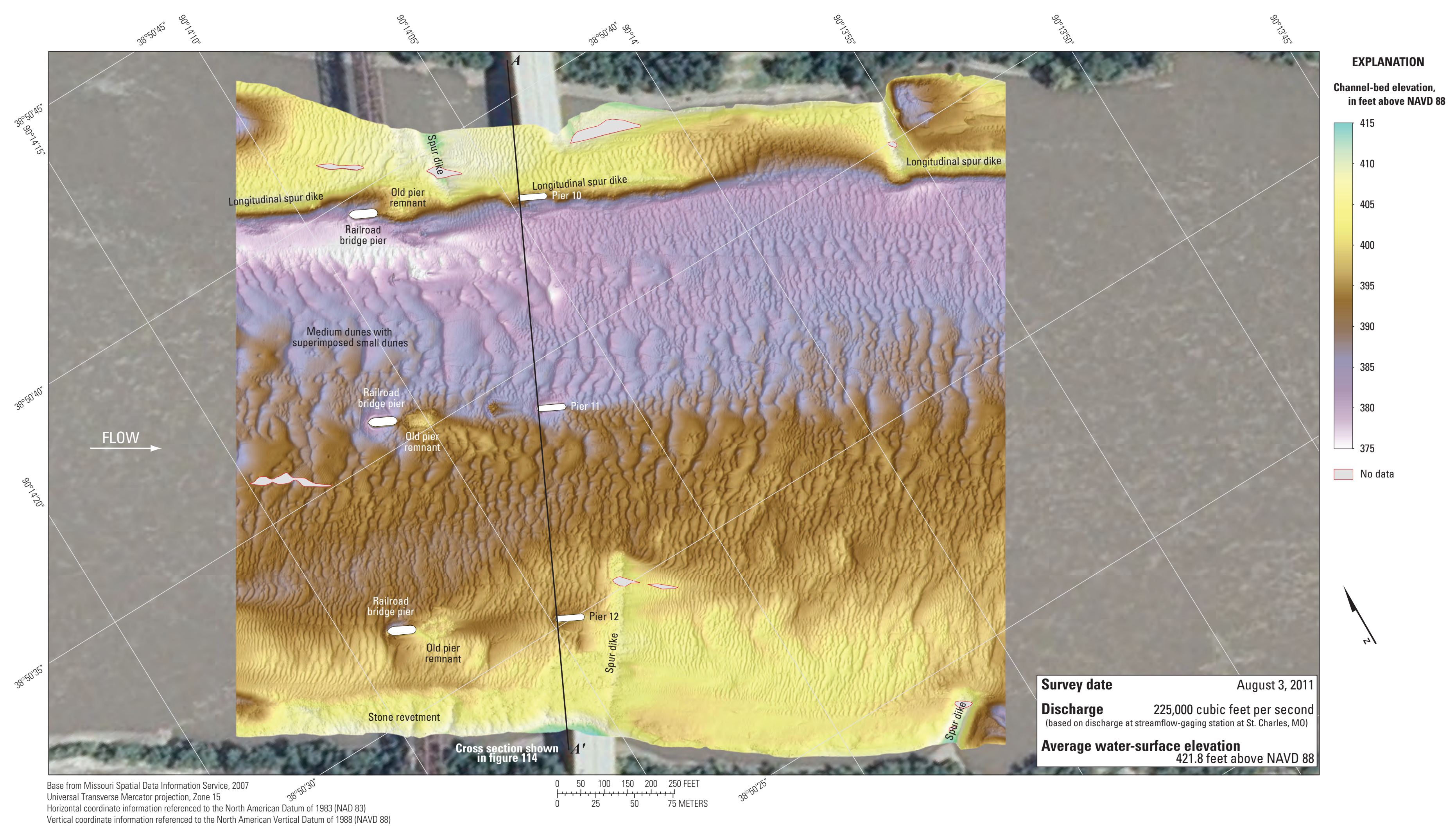

Figure 113. Bathymetric survey of the Missouri River channel in the vicinity of structure A3047 on U.S. Highway 67 near St. Louis, Missouri. 


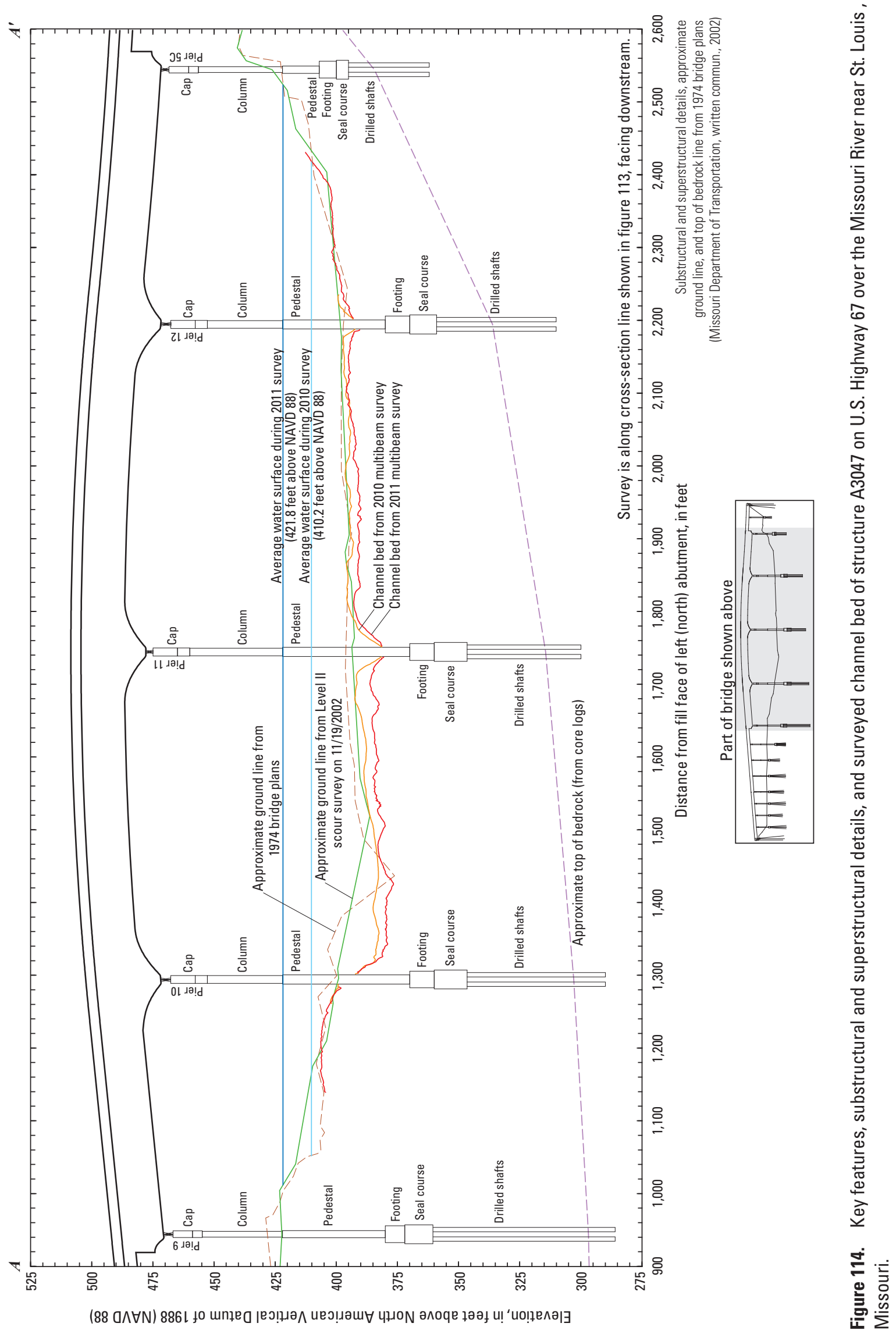




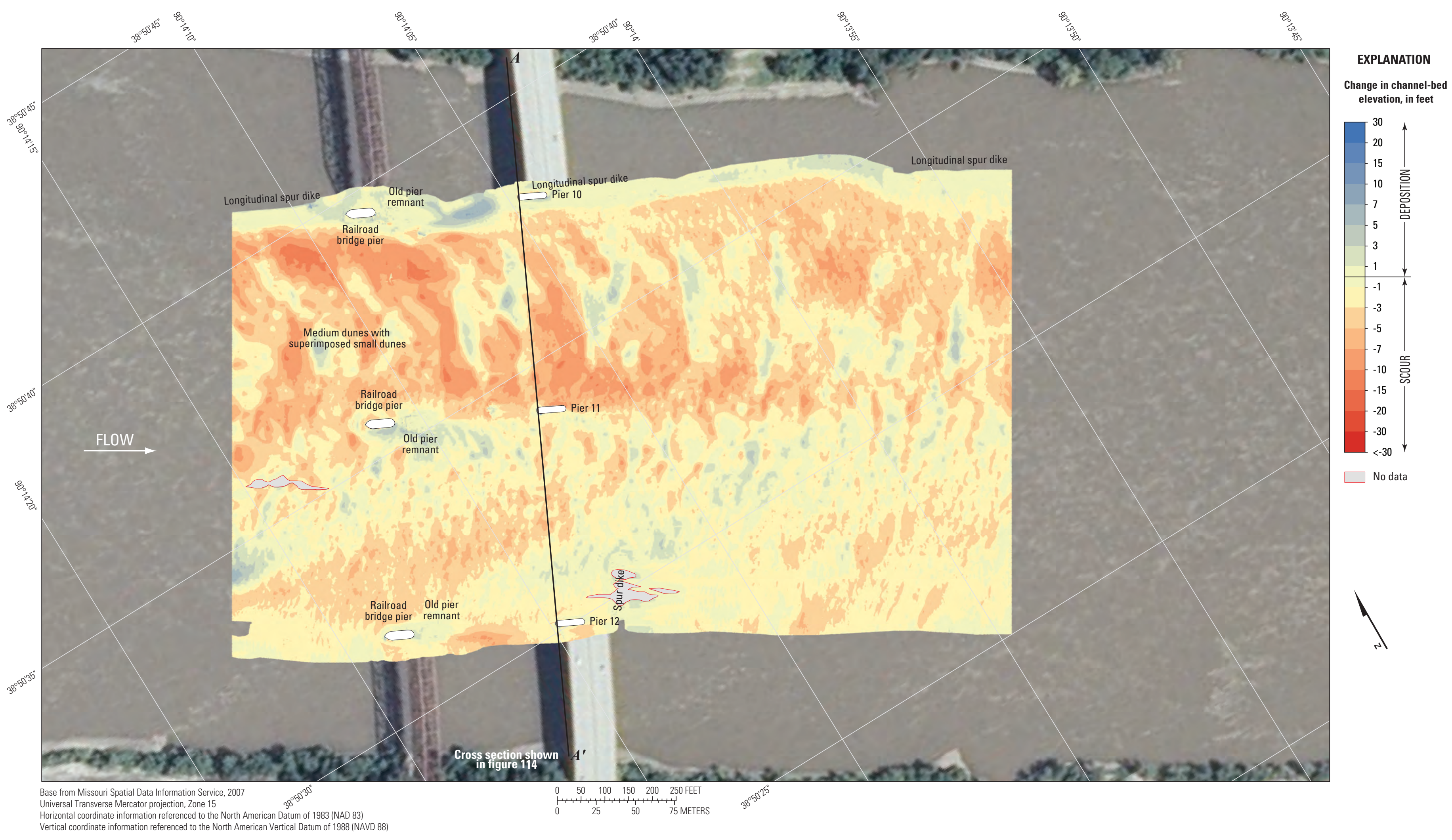

Figure 115. Difference between surfaces created from bathymetric surveys of the Missouri River channel in the vicinity of structure A3047 on U.S. Highway 67 near St. Louis, Missouri, on 0ctober 25, 2010 , and August 3, 2011. 


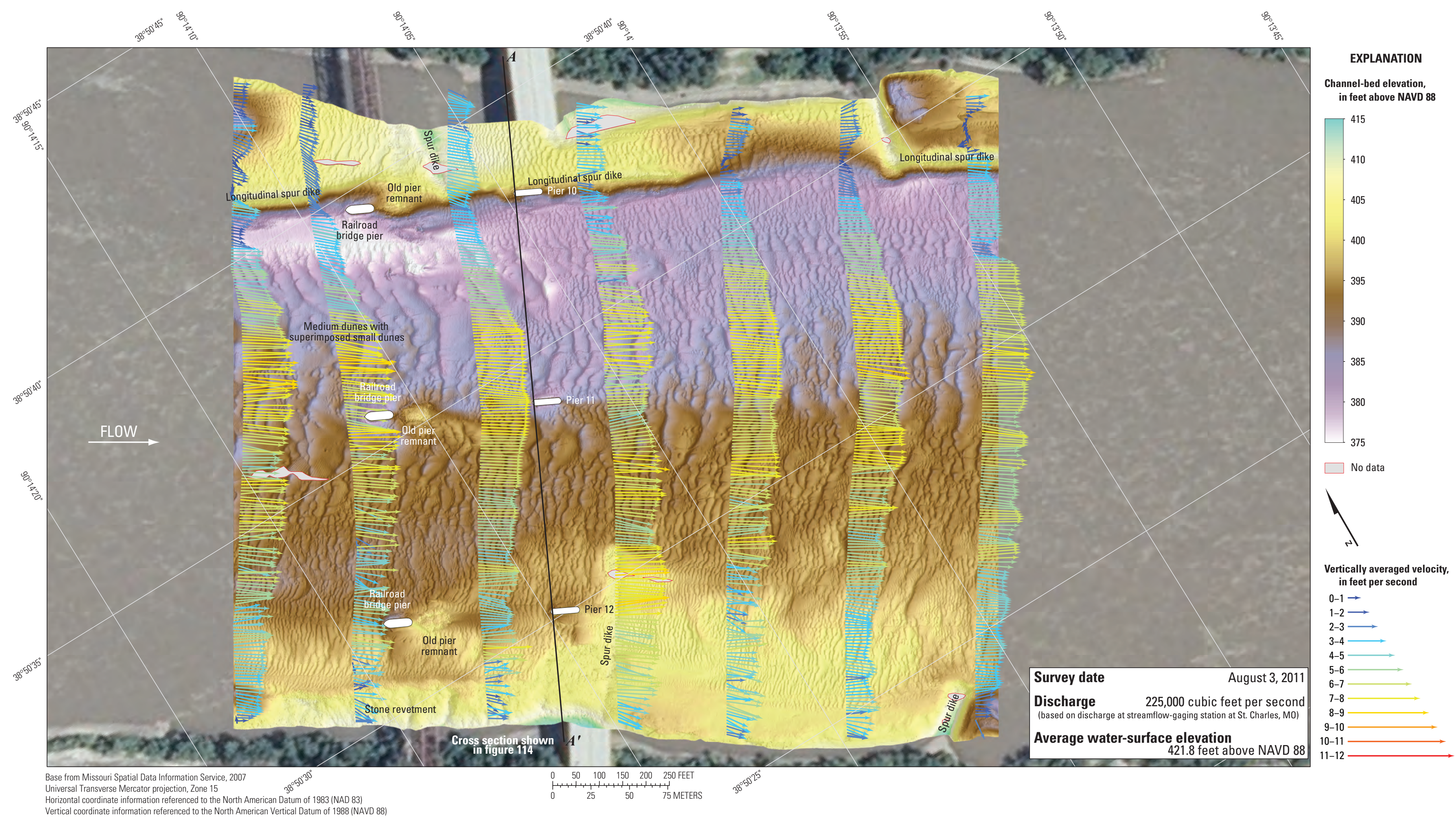

Figure 116. Bathymetry and vertically averaged velocities of the Missouri River channel in the vicinity of structure A3047 on U.S. Highway 67 near St. Louis, Missouri. 


\section{General Findings and Implications}

Several of the findings at each surveyed bridge were common to all of the bridges, and some findings were evident only when the surveys were examined as a set. These general findings are of benefit in the assessment of scour at the surveyed bridges, as well as other bridges in the vicinity or in similar settings.

\section{Effects of Moderate to High Flooding Compared to Previous Surveys}

Richardson and Davis (2001) separate long-term aggradation and degradation of a channel from the contraction and local scour that occurs at a bridge site during floods. Contraction scour is the general change in the channel-bed elevation across a bridge opening resulting from the passage of a flood through a constriction. Local scour is the localized erosion of material caused by flow vortex action that forms near bridge piers and abutments. Although all of the scour processes (longterm, contraction, and local scour) continually are at work, contraction and local scour generally are cyclic, resulting in a decrease and subsequent increase of the channel-bed elevation during the passage of a flood.

Flood durations on the Missouri generally are measured in weeks and months because of the large upstream contributing drainage area; however, the duration of the summer 2011 flood was made longer and the discharge at a given bridge was made nearly constant by the releases from the upstream reservoir system, as compared with a rainfall-derived flood event on a non-regulated stream. Therefore, it might be reasonable to assume that the cyclic scour processes typically observed were circumvented somewhat to create a stable scour scenario at a given bridge. Furthermore, if the summer 2011 flood was of greater magnitude than flow conditions during previous surveys, then it might be reasonable to assume the overall scour observed in a survey from the 2011 flood should be of a greater magnitude than that observed during a previous survey; however, comparisons with previous surveys at those sites in Kansas City and St. Louis with previous survey data confirm and contradict these assumptions.

At the seven sites in Kansas City (Huizinga, 2010), flows were about 60 percent of the 2011 amount during the 2010 surveys, and water-surface elevations were 9.5 to $10.5 \mathrm{ft}$ lower in 2010 than in 2011 (table 7); however, the bathymetric surfaces from the 2011 surveys were not consistently lower than the 2010 surveys, but varied between being $2.3 \mathrm{ft}$ lower to $4.7 \mathrm{ft}$ higher in 2011 than 2010 (table 7). Perhaps there was a plug or pulse of sediment travelling through the Kansas City area during the course of the 2011 surveys, which caused the variation in the mean difference between the 2011 and 2010 survey surfaces as one moves downstream (table 7). The depth of the scour holes from the upstream channel bed near the piers likewise was not consistently greater in 2011 than in 2010, but varied (table 6, compared with table 5 from
Huizinga, 2010). At structure A5817 on State Highway 269 in Kansas City, the bed elevation in 2011 was higher than in 2010 , such that the pier footing at pier 2 was not exposed, which caused the scour hole to be substantially smaller in 2011 than in 2010 when the channel bed was below the top of the footing (fig. 46). It is possible that the moderate flood conditions at the Kansas City sites in the previous surveys were sufficient to create a worst-case scour scenario at those sites, and that the conditions during this study were similar enough to the previous surveys to create a similar scour scenario.

At the five sites on the Missouri River near St. Louis, flows during the 2010 surveys (Huizinga, 2011) were only about 40 percent of the 2011 flows, and water-surface elevations were 9.2 to $11.7 \mathrm{ft}$ lower in 2010 than in 2011 (table 7). The bathymetric surfaces from the 2011 surveys were all lower than the 2010 surveys (table 7), but for two sites (structures A4017 and J1000 on U.S. Highway 40 and dual bridge structure A4557 on State Highway 370) the difference was almost negligible, despite the substantial difference in flow and water depth. Furthermore, there was no particular trend in difference between the survey surfaces, similar to the Kansas City area (table 7). Despite the lack of a trend, the depth of the scour holes from the upstream channel bed near the piers generally was greater in 2011 than in 2010 (table 9, compared with table 6 from Huizinga, 2011), which is consistent with the higher flow conditions. At most of the sites in St. Louis, the scour holes were less than $5 \mathrm{ft}$ deeper in 2011 than in 2010; however, at pier 15 of structure A3292 on Interstate 70, the scour hole was $9 \mathrm{ft}$ deeper in 2011 than in 2010 (fig. 104), and at upstream pier 7 of dual bridge structure A5585 on State Highway 364, the scour hole was $9 \mathrm{ft}$ deeper in 2011 than in 2010 (fig. 99) - although a debris raft likely contributed to the deeper scour hole at the latter site. The slight difference in pier scour depth at most of the piers implies that they are wellaligned with flow and narrow in aspect, with efficient nose shapes and substructural elements that are below the average channel bed during flood conditions. In the previous study at St. Louis, Huizinga (2011) noted that the scour holes observed at the bridges in the St. Louis area during the 2010 surveys likely were transient and limited in size by the moderately low flow conditions during those surveys, and that the scour holes could be larger if the bridges were to be surveyed at high-flow conditions. The moderate- to high-flow conditions during the summer 2011 flood did result in greater scour hole depths, but the effects of the higher flow conditions appeared to be mitigated by the shape and alignment of the piers.

The multiple scans at structures L0550 and A4497 on U.S. Highway 54 at Jefferson City, Missouri, indicate that moderate- to high-flow conditions can have a variable effect on scour holes at sites with a dual bridge configuration. The channel cross sections from the multiple scans near the pier of upstream structure L0550 (fig. 79) show that the scour holes differed in depth by $5 \mathrm{ft}$ or more in the three surveys, even though the January 2010 and March 2011 flow conditions were similar (water-surface elevation difference of $0.1 \mathrm{ft}$ and flow difference of $10,000 \mathrm{ft}^{3} / \mathrm{s}$; table 7). Conversely, the 
channel cross sections near the pier of downstream structure A4497 (fig. 80) show that the scour holes did not differ in depth by more than $5 \mathrm{ft}$ in the three surveys, despite the similar flow conditions of the January 2010 and March 2011 flows, and their difference from the July 2011 flow. Perhaps the turbulence from the upstream pier creates a particular scour scenario at the downstream pier that does not substantially change, despite the flow conditions; however, the fixed singlebeam monitors on the piers at this site capture the dynamic nature of the channel bed at both piers at this site, documenting the formation of scour holes driven by moderate- to highflow events, generally followed by aggradation of the channel bed during the time between high-flow events (Paul Rydlund, U.S. Geological Survey, unpub. data, 2012).

The multiple scans at structure 59-3-16.38 (013) on U.S. Highway 59 at Atchison, Kansas, also document the effects of moderate- to high-flow conditions on scour, as well as the effect of adding and removing a constriction in the channel. The first survey at this site in 2009 was during moderate- to low-flow conditions, whereas the two subsequent surveys discussed in this study were during moderate- to high-flow conditions. During the survey in 2010, the construction of the new bridge pier on the left bank downstream from the existing bridge caused a constriction of the channel. High-flow conditions, combined with the constriction, resulted in substantial scour of the overall channel, as well as increased local pier scour at the existing bridge pier (fig. 16; table 7). Conversely, even higher flow conditions occurred during the 2011 survey, but combined with the removal of the constriction resulted in deposition throughout the channel (fig. 17; table 7).

\section{Size and Shape of Scour Holes}

Generally, every pier in the main channel area for which bathymetry could be obtained had some sort of scour hole, except those on banks or embedded in spur dikes. However, the size and shape of these holes was different from one bridge to the next, and occasionally even at the same bridge site. In the local pier scour equation in Richardson and Davis (2001), pier scour is a function of several factors, including the depth and velocity of approach flow, the width and nose shape of the pier, the angle of approach flow, and the condition and armoring of the channel bed. Several of these factors as observed at the Missouri River sites in Missouri are discussed below.

For the various bridges across the Missouri River examined during the summer flooding July through August 2011, flow velocities generally were higher in the deeper parts of the channel (the thalweg), and lower in the shallow parts of the channel. Of course, there were local exceptions, such as downstream from a spur dike where a local deep area may have had a low velocity (for example, figs. 13 and 21). Exceptions notwithstanding, the size of the scour holes at sites with more than one pier in the water was related to the depth and velocity of flow upstream from the pier in question, consistent with the local pier scour equation in Richardson and Davis (2001); deeper flow or higher velocity generally resulted in larger, deeper scour holes than shallow flow or lower velocities (figs. 28, 37, 41, 48, 67, 71, 88, and 102) in the absence of a spur dike or rock outcrop that might limit local scour (pier 2 in fig. 71) or a debris raft that might exacerbate local scour (pier 7 in fig. 102; upstream pier 15 in fig. 107).

Also consistent with the local pier scour equation in Richardson and Davis (2001), piers with wide or blunt noses resulted in larger, deeper scour holes than those with narrow, round, or sharp noses. In fact, narrow piers with round or sharp noses that were aligned with flow often had scour holes that were difficult to discern from nearby small dunes and ripples (figs. 11, 45, 59, 62, 63, 72, 73, 86, 87, 89, and 90 ), whereas the scour hole generally was substantial near piers with blunt noses (figs. 14, 29, 54, 65, 68, 78, 81, and 89) and those that were rounded but wide relative to their length (figs. 7, 19, 29, 34, 38, 75, 92, and 103). Furthermore, piers that had exposure of a wide substructural element, such as a footing or seal course, resulted in larger, deeper scour holes (figs. 25, 38, 42, 49, 54, 78, and 81), again consistent with the local pier scour equation in Richardson and Davis (2001). When the channel bed immediately upstream from a pier was above the top of a footing, the scour holes near that pier occasionally did not penetrate below the top of the footing (pier 10 , fig. 12; both piers, fig. 46; pier 21, fig. 60; pier 11, fig. 63; pier 7, fig. 73; pier 5, fig. 87; and piers $2 \mathrm{C}$ and $3 \mathrm{C}$, fig. 109); the footing effectively was a scour limiter at these piers. However, it is expected that if the upstream channel bed were to lower, the wide, blunt face of the footing would be exposed and cause a substantial scour hole like those mentioned above (figs. 25, $38,42,49,54,78$, and 81 ).

Several of the surveyed bridges had piers that were skewed to approach flow, resulting in asymmetric scour holes at those bridges: structure A1 800 on Interstate 635 in Kansas City (fig. 25), structure A4649 on U.S. Highway 169 in Kansas City (fig. 34), the railroad bridge upstream from structure A4060 on State Highway 9 in Kansas City (fig. 38), structure A7650 on Interstate 35 in Kansas City (fig. 42), structures A4757 and L0568 on State Highway 291 in Kansas City (fig. 54), and structures A4017 and J1000 on U.S. Highway 40 near St. Louis (fig. 92). The scour hole typically was deeper and longer on the side of the pier with impinging flow, with some amount of deposition on the leeward side. Additionally, the various lateral and longitudinal spur dikes throughout the surveyed areas occasionally created a flow field near the surveyed bridges that caused a unique type of skewed flow, also resulting in asymmetric scour holes near certain piers that were not skewed to the primary approach flow direction. At structure 59-3-16.38 (013) on U.S. Highway 59 at Atchison, Kansas, and structures A3292 and L0561 on Interstate 70 near St. Louis, a spur dike and other constrictions on the left bank downstream from the bridges deflected flow to the right towards the center of the channel, which caused an unusual flow field in the vicinity of the left main channel piers of the highway and railroad bridges (figs. 14, 103), as well as substantial turbulence near the bridges (figs. 18, 107). Conversely, at dual bridge structure A4557 on State Highway 370 near 
St. Louis and structure A3047 on U.S. Highway 61 near St. Louis, the spur dikes on the right bank under the bridges had a negligible effect on the shape of the scour holes of piers near them (figs. 108, 113), likely because there was no additional constriction of the flow-although the spur dikes created substantial turbulence (figs. 112, 116).

In the previous studies in the Kansas City and St. Louis areas (Huizinga, 2010, 2011), the movement of bed material affected the bathymetric data and the shape of the scour holes at several of the bridges, such that several of the scour holes displayed subtle "steps" and waves in the front or along the sides of the holes. These "steps" were more pronounced in the Kansas City area bridges than in the St. Louis area bridges in the previous studies, presumably because the non-flood flow conditions during the St. Louis area surveys would result in less dynamic movement of bed material than the moderate flood conditions during the Kansas City area surveys; subsequently, the scour holes were presumed to be less likely to have lateral or longitudinal sand input in the St. Louis surveys. However, during this study, the Missouri River was in moderate- to high-flow conditions at all of the bridges, resulting in substantial and dynamic movement of bed material, yet "steps" and waves were observed at only a few bridges: at A4649 on U.S. Highway 169 in Kansas City (fig. 34), at the railroad bridge upstream from A4060 on State Highway 9 in Kansas City (fig. 38), and at A4757 on State Highway 291 in Kansas City (fig. 54). In the earliest previous survey at structures L0550 and A4497 at Jefferson City on January 26, 2010, the "steps" and waves caused the scour hole to be nearly rectangular (fig. 81A), whereas there were no such features apparent in the survey on July 27, 2011 (fig. 78).

\section{Summary and Conclusions}

Bathymetric and velocimetric surveys were conducted on the Missouri River in the vicinity of 36 highway bridges at 27 crossings between Brownville, Nebraska, and St. Louis, Missouri, by the U.S. Geological Survey in cooperation with the Kansas and Missouri Departments of Transportation. A multibeam echo sounder mapping system was used to obtain channel-bed elevations for areas ranging from 1,350 to 1,860 feet long and extending from bank to bank across the active main channel of the Missouri River during moderateto high-flow conditions. These bathymetric scans provide a "snapshot" of the channel conditions at the time of the surveys (July 13 through August 3, 2011) and provide characteristics of scour holes that may be useful in the development of predictive guidelines or equations for scour holes. These data also may be used by the Kansas and Missouri Departments of Transportation to assess the bridges for stability and integrity issues with respect to bridge scour during floods.

The estimated total propagated uncertainty for the gridded surface of each survey area was computed as an estimate of the accuracy to be expected for each point, when all relevant error sources are taken into account. An analysis of the surveys indicated that more than one-half of the bathymetric data at all the sites have a total propagated uncertainty of less than 0.50 feet, and more than 40 percent of the data at two-thirds of the sites have a total propagated uncertainty of less than 0.33 feet.

At all of the surveyed bridges, a variety of features were detected in the channel ranging from small ripples to large dune features, indicating substantial transport of sediment. Substantial rock outcrops also were detected at several sites where the alluvial material of the channel bed had been washed away, usually on one side of the channel.

Bathymetric data were collected around every pier that was in water, except those at the edge of water, in extremely shallow water, or surrounded by debris rafts. Scour holes were present at most piers for which bathymetry could be obtained, except at piers on channel banks, those near or embedded in lateral or longitudinal spur dikes, and those on exposed bedrock outcrops. Occasionally, the scour hole near a pier was difficult to discern from nearby bed features. The pier at structures 435-105-11.97 (235) and 435-105-11.98 (240) on Interstate 435 near Kansas City and the pylon at structure A7650 on Interstate 35 in Kansas City both appeared to be surrounded by mounded scour-resistant material, and did not have a well-defined scour hole that could be directly attributed to the pier or pylon. The other scour holes observed at the surveyed bridges were examined with respect to shape.

Although exposure of parts of substructural support elements was observed at several piers, at most sites the exposure likely can be considered minimal compared to the overall substructure that remains buried in bed material at these piers. The notable exceptions are structure 59-3-16.38 (013) on U.S. Highway 59 at Atchison, Kansas; structure K0999 on State Highway 41 at Miami, Missouri; structure G0069 on State Highway 240 at Glasgow, Missouri; structure A4574 on State Highway 5 at Boonville, Missouri; and structure L0550 on U.S. Highway 54 at Jefferson City, Missouri; at these structures, the bed material thickness between the bottom of the scour hole and bedrock was less than 6 feet. In modern construction, bridge substructural elements usually are pinned or socketed to bedrock, but full exposure of usually buried substructural elements warrants special consideration and observation.

Previous bathymetric surveys had been done at most of the sites in the Kansas City area and all of the sites in the St. Louis area, as well as at the bridges at Atchison, Kansas, and Jefferson City, Missouri. Comparisons between bathymetric surfaces from the previous surveys and those of this study at Kansas City show that there was no consistent deepening of the channel or increase in the size of scour holes at these sites, despite a substantial increase in discharge and water-surface elevation in the 2011 surveys. The moderate- to high-flow conditions during the 2011 surveys appeared to be similar to the flow conditions during previous surveys at Kansas City, resulting in a similar scour scenario in 2011 as the previous surveys. At Jefferson City and the St. Louis sites, there was a consistent 
deepening of the channel, and a slight to substantial increase in the depth of scour holes in the 2011 surveys compared to previous surveys. The moderate- to high-flow conditions during the summer 2011 flood resulted in greater scour hole depths at St. Louis, but the effects of the higher flow conditions appeared to be mitigated by the shape and alignment of the piers at most sites. Construction activities related to a new bridge at the Atchison, Kansas, site likely has contributed to the substantial additional scour observed there in a previous survey during the 2010 flooding, and the subsequent rise in the channel bed observed in the 2011 survey.

Pier size, nose shape, and alignment to flow had a profound effect on the size of the scour hole observed for a given pier. Narrow piers with round or sharp noses that were aligned with flow often had scour holes that were difficult to discern from nearby bed features, whereas piers with wide or blunt noses resulted in larger, deeper scour holes. Several of the structures had piers that were skewed to primary approach flow, and spur dikes near piers at two sites caused localized flow disturbances similar to skewed approach flow. Scour holes near these piers displayed similar characteristics, generally with deposition on the leeward side of the pier and greater depth on the side of the pier with impinging flow.

\section{Acknowledgments}

The author wishes to thank Joseph M. Richards and E. Scott Southern of the USGS Missouri Water Science Center for their assistance in the field during data collection, and in the office processing the substantial amount of data after collection. Southern processed all the velocity data and Richards helped process the bathymetry data and was instrumental in creating the various bathymetric, velocimetric, and difference maps for the report.

\section{References Cited}

American Association of State Highway Transportation Officials, 2012, AASHTO LRFD bridge design specifications, Section 10, (Customary U.S. Units, 6th ed.): Washington, D.C., $167 \mathrm{p}$.

Applanix Corporation, 2009, POS-Pac ${ }^{\mathrm{TM}}$ MMS ${ }^{\mathrm{TM}}$ GNSSinertial tools user guide, Rev. 4: Richmond Hill, Ontario, Canada, PUBS-MAN-001768, 523 p.

Brown, D.A., Turner, J.P., and Castelli, R.J., 2010, Drilled shafts - Construction procedures and LRFD Design Methods: U.S. Federal Highway Administration Publication FHWA-NHI-10-016 Geotechnical Engineering Circular No. 10, 970 p.
Calder, B.R., and Mayer, L.A., 2003, Automatic processing of high-rate, high-density multi-beam echosounder data: Geochemistry, Geophysics, Geosystems, v. 4, p. 1,048.

Czuba, J.A., Best, J.L, Oberg, K.A., Parsons, D.R., Jackson, P.R., Garcia, M.H., and Ashmore, P., 2011, Bed morphology, flow structure, and sediment transport at the outlet of Lake Huron and in the Upper Saint Clair River: Journal of Great Lakes Research, v. 37, no. 3, p. 480-493.

Environmental Systems Research Institute, 2010, ArcGIS, accessed September, 2010, at http://www.esri.com/software/ arcgis/

Holmes, R.R., Jr., Schwein, N.O., and Shadie, C.E., 2012, Flood risk awareness during the 2011 floods in the central United States - Showcasing the importance of hydrologic data and interagency collaboration: American Society of Civil Engineers, Leadership and Management in Engineering, v. 12 , no. 3, p. 101-110.

Huizinga, R.J., 2010, Bathymetric surveys at highway bridges crossing the Missouri River in Kansas City, Missouri, using a multibeam echo sounder, 2010: U.S. Geological Survey Scientific Investigations Report 2010-5207, 61 p.

Huizinga, R.J., 2011, Bathymetric surveys at highway bridges crossing the Missouri and Mississippi Rivers near St. Louis, Missouri, 2010: U.S. Geological Survey Scientific Investigations Report 2011-5170, 75 p.

Huizinga, R.J., Elliott, C.M., and Jacobson, R.B., 2010, Bathymetric and velocimetric survey and assessment of habitat for pallid sturgeon on the Mississippi River in the vicinity of the proposed Interstate 70 Bridge at St. Louis, Missouri: U.S. Geological Survey Scientific Investigations Report 2010-5017, $28 \mathrm{p}$.

Huizinga, R.J., and Rydlund, P.H., Jr., 2004, Potential-scour assessments and estimates of scour depth using different techniques at selected bridge sites in Missouri: U.S. Geological Survey Scientific Investigations Report 2004-5213, $42 \mathrm{p}$.

HYPACK, Inc., 2011, HYPACK ${ }^{\circledR}$ Hydrographic survey software user's manual 02/11: Middletown, Conn., 1,582 p.

Lagasse, P.F., Shall, J.D., Johnson, F., Richardson, E.V., Richardson, J.R., and Chang, F., 1991, Stream stability at highway structures: U.S. Federal Highway Administration Publication FHWA-IP-90-014 Hydraulic Engineering Circular No. 20, 195 p.

Mueller, D.S., and Wagner, C.R., 2009, Measuring discharge with acoustic Doppler current profilers from a moving boat: U.S. Geological Survey Techniques and Methods, book 3, chap. A22, 72 p. 
National Oceanic and Atmospheric Administration, 2012a, Advanced Hydrologic Prediction Service Precipitation Analysis: National Weather Service, accessed August 2012, at http://water.weather.gov/precip/index.php

National Oceanic and Atmospheric Administration, 2012b, United States flood loss report_-Water year 2011: National Weather Service, accessed March 2012, at http://www.nws. noaa.gov/hic/summaries/WY2011.pdf

Oberg, K.A., Morlock, S.E., and Caldwell, W.S., 2005, Quality-assurance plan for discharge measurements using acoustic Doppler current profilers: U.S. Geological Survey Scientific Investigations Report 2005-5183, 35 p.

Richardson, E.V., and Davis, S.R., 2001, Evaluating scour at bridges (4th ed.): U.S. Federal Highway Administration Publication FHWA NHI 01-001 Hydraulic Engineering Circular No. 18, 378 p.

Rydlund, P.H., Jr., 2009, Real-time river channel-bed monitoring at the Chariton and Mississippi Rivers in Missouri, 2007-09: U.S. Geological Survey Scientific Investigations Report 2009-5254, 27 p.

Simon, Li and Associates, 1985, Seasonal effects of river stage-discharge relations at selected gages, final report: Fort Collins, Colorado, prepared for U.S. Army Corps of Engineers, Contract No. DACW43-85-D-0017, 96 p.
U.S. Army Corps of Engineers, 2004a, Upper Mississippi River System flow frequency study, appendix F: U.S. Army Corps of Engineers, Rock Island, Ill., accessed March 2012, at http://www.mvr.usace.army.mil/pdw/pdf/flowfrequency/ Documents/FinalReport/default.asp.

U.S. Army Corps of Engineers, 2004b, Upper Mississippi River System flow frequency study, appendix E: U.S. Army Corps of Engineers, Rock Island, Ill., accessed March 2012, at http://www.mvr.usace.army.mil/pdw/pdf/flowfrequency/ Documents/FinalReport/default.asp.

U.S. Army Corps of Engineers, 2004c, Engineering and design-Hydrographic surveying: Washington D.C., U.S. Army Corps of Engineers, manual no. EM 1110-2-1003, $560 \mathrm{p}$.

U.S. Geological Survey, 2003, User's manual for the National Water Information System of the U.S. Geological Survey-Automated Data Processing System (ADAPS): U.S. Geological Survey Open-File Report 2003-123, 413 p., accessed September 2010, at http://pubs.usgs.gov/of/2003/ ofr03123\%.

U.S. Geological Survey, 2012, National Water Information System: U.S. Geological Survey database, accessed March 2012, at http://waterdata.usgs.gov/nwis/.

Publishing support provided by:

Rolla Publishing Service Center

For more information concerning this publication, contact:

Director, USGS Missouri Water Science Center

1400 Independence Road

Rolla, MO 65401

(573) 308-3667

Or visit the Missouri Water Science Center Web site at:

http://mo.water.usgs.gov/ 


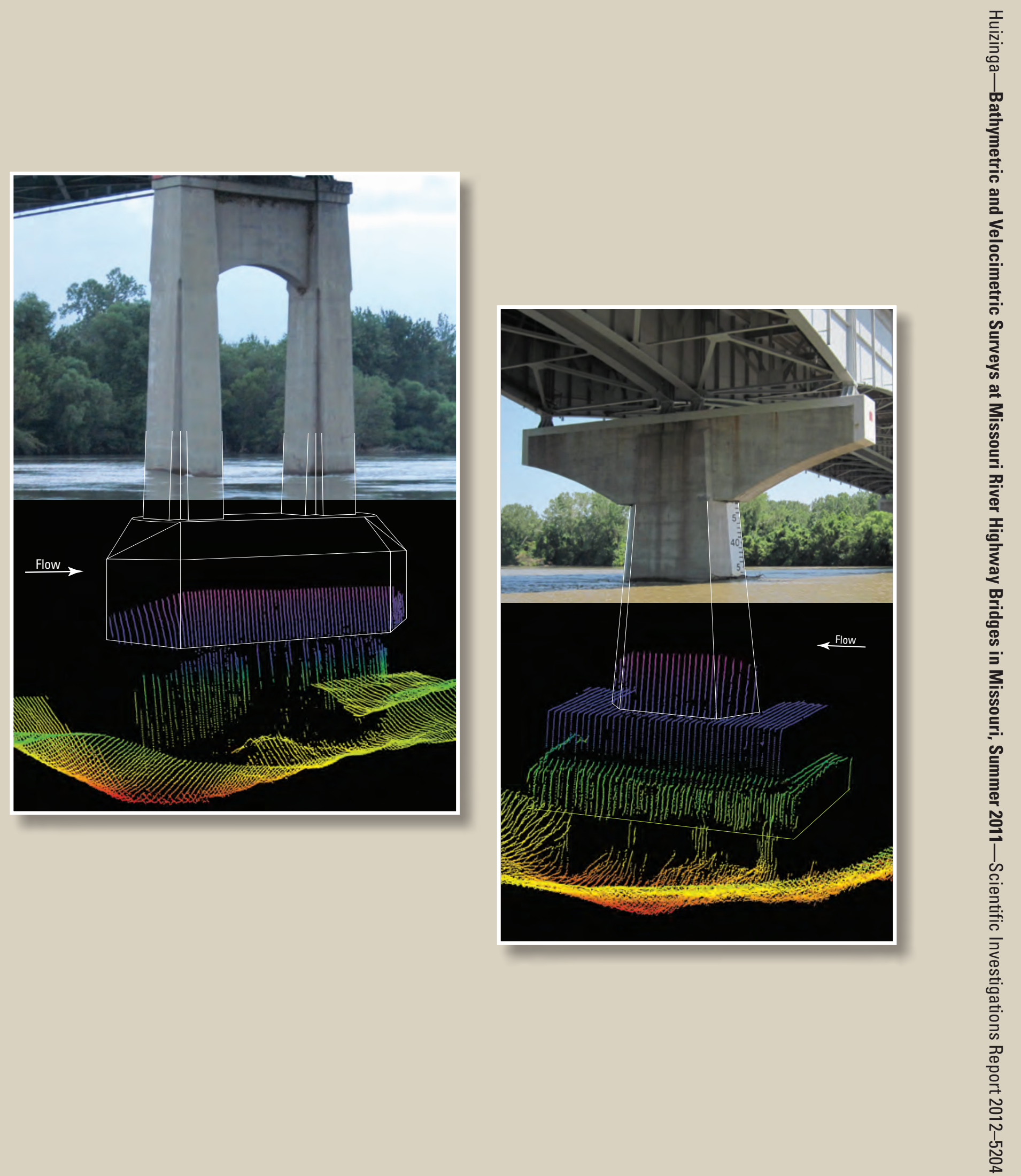